Ivita Faituša

\title{
lekšējā audita izvērtējums un pilnveidošanas iespēju analize Latvijas valsts tiešajā pārvaldē un pašvaldībās
}


Ivita Faituša

\section{lekšējā audita izvērtējums un pilnveidošanas iespēju analīze Latvijas valsts tiešajā pārvaldē un pašvaldībās}

Monogrāfija

LU Akadēmiskais apgāds

2019 
Ivita Faituša. Iekšèjā audita izvērtējums un pilnveidošanas iespēju analīze Latvijas valsts tiešajā pārvaldē un pašvaldībās. Rīga: LU Akadēmiskais apgāds, 2019. 188 lpp.

Recenzenti:

Dr. oec. Ingrīda Jakušonoka, Latvijas Lauksaimniecības universitātes profesore, Dr. oec. Iveta Mietule, Rēzeknes Tehnolog̣iju akadēmijas profesore, Dr. oec. Rasa Subačiene (Rasa Subačiene), Viḷnas Universitātes profesore.

Zinātniskā konsultante Dr. oec. Inta Brūna, Latvijas Universitātes profesore.

Monogrāfija akceptēta un rekomendēta publicēšanai Latvijas Universitātes Biznesa, vadības un ekonomikas fakultātes Domes sēdē 2018. gada 4. decembrī; lēmums Nr. BVEF-12.2/15.

Monogrāfija izdota Latvijas Universitātes Zinātniskās darbības attīstības projekta Nr. AAP 2018/130 "Monogrāija Iekšējā audita izvērtējums un attīstības iespēju analīze Latvijas valsts tiešajā pārvaldē un pašvaldībās" ietvaros, ar SIA "Grant Thornton Baltic" Latvijā un SIA "If Birojs" atbalstu.

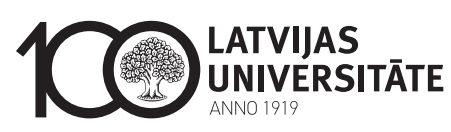

Literārā redaktore Sandra Priedìte

Maketētāja Andra Liepiṇa

Vāka foto: shutterstock.com

\section{- GrantThornton}

An instinct for growth"

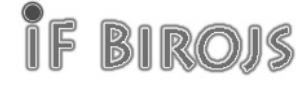




\section{SATURS}

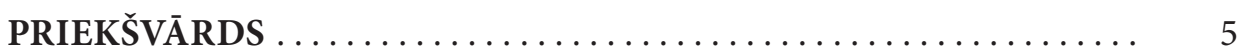

\section{IEKŠĒJ̄Ā AUDITA ATTİSTİBAS ANALĪZE STARPTAUTISKĀ}

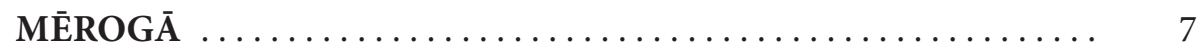

1.1. Iekšejejā audita vēsturiskās rašanās teorētiskās atziṇas . ........ 7

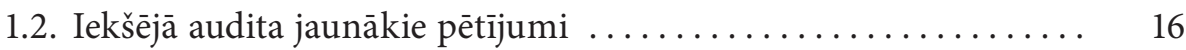

1.3. Iekšèjā audita definīcija, starptautiskie standarti un

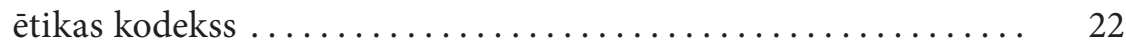

1.4. Iekšèjā audita attīstìba publiskajā sektorā mūsdienās ......... 31

1.4.1. Iekšèjā audita funkcija un tās nozīme .............. 31

1.4.2. Iekšèjā audita pieejas valsts pārvaldē Eiropā .......... 36

1.5. Iekšèjā audita loma risku vadības procesā ............... 44

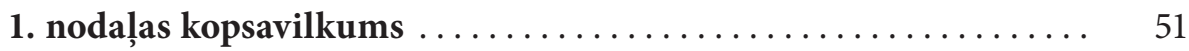

\section{LATVIJAS VALSTS PĀRVALDES IEKŠĒJ̄Ā AUDITA}

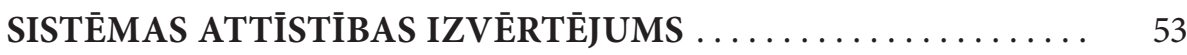

2.1. Iekšèjā audita sistēma Latvijas valsts pārvaldē ............ 53

2.1.1. Latvijas valsts pārvaldes sistēmas raksturojums ........ 53

2.1.2. Iekšejāa audita normatīvais regulējums Latvijas valsts tiešajā pārvaldē .......................... 56

2.1.3. Iekšèjā audita loma Latvijas valsts tiešajā pārvaldē ...... 64

2.2. Iekšèjā audita sistēma Latvijas pašvaldībās .............. 74

2.2.1. Latvijas pašvaldỉbu raksturojums ............... 74

2.2.2. Latvijas pašvaldỉbu iekšejā audita pieejas ............ 82

2. nodaḷas kopsavilkums ........................ $\quad 95$ 


\section{LATVIJAS VALSTS TIEŠĀS PĀRVALDES UN LATVIJAS PAŠVALDĪBU IEKŠĒJ̄Ā AUDITA PILNVEIDOŠANAS}

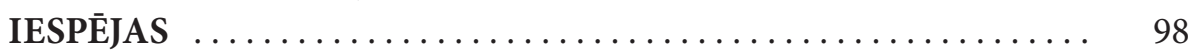

3.1. Iekšèjā audita pilnveidošana valsts tiešajā pārvaldē .......... 98

3.2. Latvijas pašvaldību iespējamie risinājumi iekšèjā

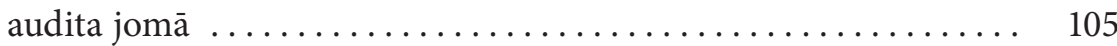

3.2.1. Iekšèjā audita nepieciešamība .................. 105

3.2.2. Iespējamie iekšèjā audita risinājumi pašvaldībās ....... 112

3. nodal̦as kopsavilkums $\ldots \ldots \ldots \ldots \ldots \ldots \ldots \ldots \ldots \ldots \ldots \ldots$

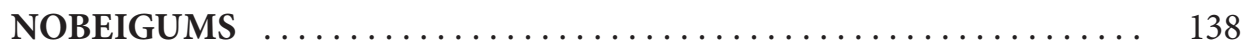

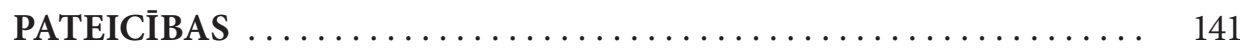

ABREVIATŪRU SARAKSTS $\ldots \ldots \ldots \ldots \ldots \ldots \ldots \ldots \ldots \ldots . \ldots \ldots$

IZMANTOTĀS LITERATŪRAS UN AVOTU SARAKSTS . . . . . . . 143

Latvijas Republikas likumi, valdïbas noteikumi u. c.

normatīvie akti, statistikas dati ..................... 143

Autoru darbi ..................................... 145

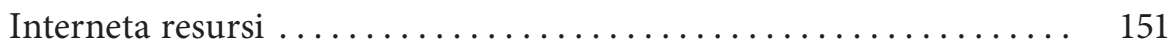

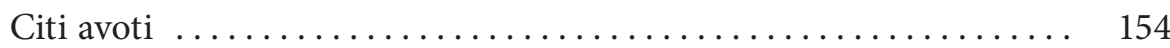

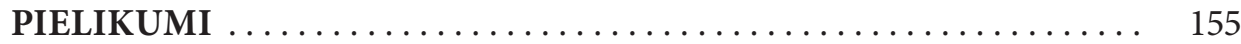

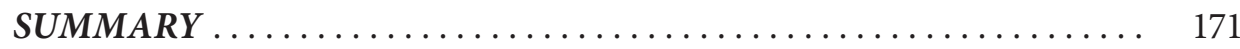




\section{PRIEKŠVĀRDS}

Iekšējais audits mūsdienās tiek uzskatīts par būtisku pakalpojumu visos vadības līmeṇos, jo iekšejā auditora ieteikumi un organizācijas vadības pieṇemtie lēmumi var būt nozīmīgi faktori organizācijas darbības turpināšanai, reorganizācijai u. tml., taču vēl joprojām iekšējais audits netiek novērtēts pienācīgi un pilnīgi, tas arvien tiek uzskatīts par slogu visos vadības līmeņos. Šobrīd, novērtējot esošos procesus, iekšejāa audita galvenais uzdevums ir sagatavot ieteikumus vadībai, kas vērsti uz turpmāku procesu uzlabošanu, tādējādi ar kompetentu iekšējo auditoru palīdzību organizācijai radot pievienoto vērtību.

Latvijā iekšējais audits pastāv publiskajā sektorā, banku sektorā un privātajā sektorā. Katrā sistēmā iekšējais audits darbojas citādi: valsts pārvaldē un banku sektorā ir noteiktas normatīvo aktu prasības, privātajā sektorā iekšèjā audita sistēma tiek ieviesta pēc īpašnieku un vadības lēmuma. No valsts tautsaimniecỉbas viedokḷa visnozīmīgākā iekšejā audita loma ir valsts pārvaldē, kur ḷoti svarīga ir procesu likumīga un taisnīga norise, kvalitatīva un efektīva personāla politika, ekonomisks un pamatots lìdzekḷu izlietojums un budžeta izpilde.

Eiropas valstu iekšejā audita un iekšèjās kontroles sistēma ir ieviesta atbilstoši ES normatīvo aktu prasībām, taču katrā valstī sistēmas darbojas atškirīịi. Latvijas pašvaldībās iekšējā audita sistēma netiek regulēta ar normatīvajiem aktiem, iekšējie auditori darbojas pēc dažādām metodēm, rezultāti netiek apkopoti un nav publiski pieejami.

Jau kopš 1943. gada ārzemju autori ir izstrādājuši dažādas publikācijas par iekšējo auditu - iekšējā audita pirmsākumu metodikas un rokasgrāmatas, analizējuši un salīdzinājuši iekšejā audita attīstību dažādās pasaules valstīs, veikuši iekšèjā audita funkcijas analīzi publiskajā sektorā u. c. Nozīmīgus un apjomīgus pētījumus iekšèjā audita jomā pēdējos gados daži zinātnieki izstrādājuši, pamatojoties uz CBOK (Common Body of Knowledge) Iekšèjo auditoru institūta pētījumu fonda (turpmāk - IAIPF) globālajām aptaujām (2006, 2010, 2015). Tās ietver vairāku tūkstošu visas pasaules iekšējo auditoru veiktās aptaujas un analītiskos pētījumus par iekšèjā audita funkciju, metodologiju, iekšējo auditoru kvalifikāciju u. c. iekšējā audita pievienotās vērtības indikatoriem, tāpat arī 
Eiropas Komisija 2012. un 2014. gadā ir publicējusi ziņojumus par iekšējā audita un iekšējās kontroles sistēmu ieviešanu un darbību ES valstīs.

Latvijā nozīmīgs pētījums iekšèjā audita jomā ir bijis R. Šulcas promocijas darbs 2010. gadā par iekšējā audita pilnveidošanas iespējām Latvijas pašvaldībās. 2012. gadā G. Vērdiṇa savā pētījumā par iekšējās kontroles sistēmas pilnveidošanu vienu apakšnodaļu ir veltījusi iekšèjā audita kā iekšêjās kontroles sistēmas novērtēšanas instrumentam un tā attīstībai. Svarīgi, ka arī 2019. gada sākumā iekšējā audita sistēma Latvijas pašvaldībās darbojas atškịingi, nav vienotas pieejas un ir daudz neskaidrību pašiem iekšējiem auditoriem.

Šajā pētījumā autore ir veikusi iekšejāa audita izvērtējumu valsts tiešajā pārvaldē un pašvaldībās, izmantojot auditoru un ekspertu aptaujas, izstrādājusi iekšèjā audita ieviešanas modeli Latvijas pašvaldībās, kā arī pašvaldỉbu iekšêjā audita vērtēšanas pieeju un iekšèjā audita pievienotās vērtỉbas jeb ieguvumu sarakstu. 


\section{IEKŠẼJĀ AUDITA ATTİSTİ̈AS ANALĪZE STARPTAUTISKĀ MËROGĀ}

\section{1. lekšējā audita vēsturiskās rašanās teorētiskās atziṇas}

Iekšèjo auditu no vēsturiskā aspekta autore ir pētijjusi, lai veidotu analītisku apkopojumu un izdalītu iekšęjā audita attīstības fāzes. Iekšejāa audita vēsturiskos aspektus aprakstījuši un iekšèjā audita attīstību pētījuši vairāki autori pasaulē, piemēram, iekšęjā audita rašanās tiek definēta kā audita pirmsākumi, neizdalot atsevišķi ārējo auditu un/vai iekšējo auditu, ko savos pētijumos par iekšêjā audita tēmām kopš 20. gadsimta vidus aprakstijjuši un saistībā ar kuru savu priekšteču darbu turpinājuši gan pētnieki, gan iekšèjā audita speciālisti visā pasaulē. Iekšèjā audita pētnieki S. Ramamoorti un W. H. A. Swinkels ${ }^{1}$ uzskata, ka nepieciešamība pēc ārējā un iekšèjā audita radusies no vajadzības veikt neatkarīgas pārbaudes, lai iestādēs mazinātu kḷūdas uzskaitē, kā arī aktīvu piesavināšanos un krāpšanu.

Audita pirmsākumus ir aprakstījis grāmatvedības vēsturnieks $R$. Brown 1905. gadā, kuru 1961. gadā citējuši Mautz \& Sharafizdevumā "Audita filozofija" (The Philosophy of Auditing) apgalvojot, ka "audita izcelsme meklējama tikpat sen, kā grāmatvedības pirmsākumi (..). Kad civilizācijā radās nepieciešamība otram uzticēt svešu īpašumu, lietderīga bija kāda veida pārbaude, kas radītu skaidrību"2. Tas nozīmē, ka precīzu laiku audita pirmsākumiem pašlaik noteikt nav iespējams, taču nenoliedzami ir fakti, kas atspoguḷojas vēsturiskās liecībās un zinātnieku pètījumos visā pasaulē.

Vairāki iekšèjā audita pētnieki, piemēram, P. P. Gupta un M. R. Ray (1992), S. Ramamoorti (2003), W. H. A. Swinkels (2012), iekšējā audita pirmsākumus saista ar pirmās formālās grāmatvedības ierakstu sistēmas veidošanos, kas

\footnotetext{
1 Ramamoorti S. (2003) Chapter 1: Internal Auditing: History, Evolution, and Prospects. The IIA Research Foundation, Altamonte Springs, Florida, pp. 2-14; Swinkels W. H. A. (2012) Exploration of a theory of internal audit. Akademisch proefschrift. Universiteit van Amsterdam, p. 27.

2 Turpat.
} 
meklējami tālajā 4000.-3500. g. p.m.ē. Tuvajos Austrumos, lai kliedētu bažas par pareizu ieņēmumu, izdevumu un nodokḷu iekasēšanu. Līdzīga situācija bija Zhao dinastijas laikā Ķīnā (112.-256. g. p.m.è.). Nepieciešamība pēc audita un norādes uz tā attīstību vērojamas Babilonijas, Grieķijas, Romas impērijas un Itālijas pilsētvalstu finanšu sistēmās, kur attīstījās detalizēti pārbaužu veidi un skaitītāju pārbaudes. İpaši šo valstu valdības uztraucās gan par nekompetentām amatpersonām, kas varētu kḷūdīties un pię̧aut neprecizitātes, gan par korumpētiem ierēdñiem, kuri bija motivēti krāpties, ja rastos tāda iespēja.

Lìdzīgas domas par to, ka Eiropā audita nepieciešamība praktiski veidojās jau Senajā Romā, izmantojot uzklausǐšanu, grāmatvežu un finanšu ierakstu pārbaudes, kas paredzētas, lai novērstu krāpnieciskas darbības, savos darbos pauž M. A. Dittenhofer, L. B. Sawyer un W. H. A. Swinkels. Šie autori savās publikācijās apgalvo, ka, pirmkārt, ierakstu uzklausiš̌anas uzdevuma rezultātā radās termins "audits" (cēlies no latīnu valodas 'auditus' vai 'audire', kas nozīmē "klausǐšanās/dzirdēšana" vai "klausīties/dzirdēt"), otrkārt, ka uzklausišsanai liela nozīme bija laikā, kad daudzi cilvēki neprata rakstīt un lasīt, un, treškārt, auditori tika izraudzīti no sabiedrības vidus, no viniem tika sagaidīta profesionalitāte un kompetence krāpšanās un kḷūdu atklāšanā.

Pētnieki P. P. Gupta un M. R. Ray 1992. gadā pētījumā "The Changing Roles of the Internal Auditor" un 1966. gadā A. C. Littleton darbā "Accounting Evolution to 1900" min, ka 1298. gadā Londonas pilsētas galma pārvaldnieku auditēja komiteja, kuras sastāvā bija dažādas valdības amatpersonas.

W. H. A. Swinkels pētijumā "Exploration of a theory of internal audit" konstatē, ka 13. gs. sākumā Pizā oficiāli tika iecelti pirmie divi valsts auditori: iekšèjais auditors un ārējais auditors. Lìdz 1900. gadam audita profesija attīstījās, piemērojot sistemātisku pieeju, un kḷuva daudz plašāka. Profesionālo auditoru asociācija ir dibināta 16. gs. Venēcijā, Boloṇā un Milānā. Iekšêjie auditori galvenokārt bija valsts auditori, kuri rīkojās karaļa un/vai valsts vārdā. Laika periodā no 16. gadsimta līdz 18. gadsimtam auditoru pienākumi tika paplašināti un ietvēra uz biznesu orientētās sabiedrības darījumus, akcentējot krāpšanās atklāšanu un novēršanu un tos pārbaudot gan ar pašu auditoru, gan katra atsevišķā darījuma dokumentiem. 18. un 19. gadsimtā ASV un Eiropā iekšèjā audita attīstībā liela loma bija dažādiem vēsturiskiem notikumiem, piemēram, "Dienvidu jūras burbulim", “Tulpju skandālam”, dzelzcel̦u sistēmu attīstībai. Svarīgāka loma organizācijās tika piešķirta vadītāju kontroles īstenošanas pasākumiem.

\footnotetext{
3 Swinkels W. H. A. (2012) Exploration of a theory of internal audit. Akademisch proefschrift. Universiteit van Amsterdam, pp. 27-28.
} 
Iekšējais audits straujāk attīstijās 19. un 20. gadsimtā vienlaikus ar korporatīvā biznesa uzplaukumu, kad pieauga pieprasījums pēc dažādām kontrolēm, daudzās jomās nodarbinot tūkstošiem cilvēku visā pasaulē. S. Ramamoorti un W. H. A. Swinkels ${ }^{4}$ savos pètījumos atzīmē, ka 19. gadsimtā Lielbritānijā un ASV dzelzceļu un uzskaites sistēmas attīstība veicināja iekšèjā audita attīstîbu, jo tika ieviestas jaunas procedūras, dzelzceļu firmas sāka liela apjoma un geogrāfiski plašus darījumus, bet iekšējais auditors bija nepieciešams, lai uzraudzītu finanšu darījumu procesu (maksājumu kvītis, naudas atlikumus, staciju ienākumus). Tas bija kaut kas līdzịgs finanšu auditam, taču iekšējie auditori pārbaudīja arī citus, ne tikai finanšu datus, piemēram, nepietiekamu detaļu daudzumu, grafiku ievērošanu un produktu kvalitāti.

A. Collins par pašvaldību iekšējo auditu darbā "Municipal Internal Auditing" rakstīja jau 1904. gadā, pēc tam publikācijas aktualizējot 1913., 1939., 1943. un 1948. gadā. Tajās viņš skaidroja pilnu pašvaldību ieṇēmumu iekšējo auditu, pamatojoties uz sistēmām, kas ieviestas Apvienotās Karalistes nozīmīgākajās pašvaldībās ar mērḳi palīdzēt studentiem sagatavoties pašvaldību mantziṇu un grāmatvežu iestājeksāmeniem institūtā.

S. Ramamoorti 2003. gada pētījumos ${ }^{5}$ min būtisku faktu par pirmajām publikācijām saistībā ar iekšējo auditu, piemēram, Teksasas Universitāte publicēja Dr. C. A. Smith darbu "Iekšējā audita kontrole" (Internal Audit Control), 1933. gadā publicēta arī viṇa doktora disertācija Kolumbijas Universitātē. Disertācijā citēts 1930. gada izdevums "Iekšējais audits" (Internal Auditing), ko publicējusi Starptautiskā Grāmatvežu asociācija Čikāgā. Tāpat C. A. Smith ir atsaucies uz 1927. gadā National Electric Light Association izdoto brošūru "Iekšèjie auditi" (Internal Audits). Daudzi citētie raksti ir par "iekšējām pārbaudēm” un "iekšêjo kontroli", bet tikai divi no tiem, kas publicēti laikā no 1928. līdz 1931. gadam, ir par "iekšējo auditu” vai "iekšējiem auditoriem”.

V. Z. Brink (1906-1992) ir bijis gan akadēmiskais darbinieks Kolumbijas Universitātē ASV, gan praktikikis uzṇēmumos Ford Motor un Pure Oil. V. Z. Brink personību IAI raksturo kā ietekmīgāko iekšèjā audita vēsturē. Viņš bija viens no trim IAI dibinātājiem un pirmais IAI zinātniskais vadītājs, uzrakstīja pirmo grāmatu "Iekšējais audits" (Internal Auditing), kas balstīta uz doktora tēzēm un publicēta 1941. gadā ASV; pēc tam izdevums atkārtoti izdots 1958. gadā.

\footnotetext{
${ }_{4}$ Swinkels W. H. A. (2012) Exploration of a theory of internal audit. Akademisch proefschrift. Universiteit van Amsterdam, pp. 27-28.

5 Ramamoorti S. (2003) Chapter 1: Internal Auditing: History, Evolution, and Prospects. The IIA Research Foundation, Altamonte Springs, Florida, pp. 2-14; Swinkels W. H. A. (2012) Exploration of a theory of internal audit. Akademisch proefschrift. Universiteit van Amsterdam, p. 27.
} 
1941. gada izdevumu daudzi autori ir papildinājuši un izdevuši atkārtoti. R. R. Moeller turpinājis publikācijas ar darbu "Brink's Modern Internal Auditing". 1943. gadā ASV izdota V. Z. Brink grāmata "Managerial control through internal audit", kas ietver gan teorētiskos skaidrojumus, gan dokumentu un sadarbibas aprakstus.

1941. gada 17. novembrī ASV iekšējā audita praktiḳi V. Z. Brink, R. B. Milne un J. B. Thurston nodibināja Iekšējo auditoru institūtu (IAI). J. B. Thurston ievēlēja par pirmo IAI prezidentu. Organizācijas biedru skaits strauji auga, un jau pirmā gada beigās tas sasniedza 104, bet nākamajos piecos gados - 1018 biedrus. 1957. gadā institūts apvienoja 3700 biedrus, no kuriem 20\% bija ārpus ASV. Šobrīd IAI biedru skaits ir pāri 185000 biedru vairāk nekā 170 valstīs visā pasaulē. ${ }^{7}$

S. Ramamoorti savā vēsturiskajā iekšèjā audita pētijumāe iekḷāva $R$. B. Milne 1945. gadā formulēto atziṇu, ka Iekšèjo auditoru institūts ir izveidojies, lai attīstītu iekšêjā audita profesiju, pateicoties iekšējo auditoru pārliecībai, ka Amerikas biznesā IA ir nepieciešama struktūrvienība. Lai gan IA pirmsākumi meklējami grāmatvedībā, tā galvenais mērķis ir vadība kontroles jomā, kas ietver pilnīgu uzņēmuma iekšējo finanšu un darbības pārskatu.

Iekšējo auditoru institūts 1950. gadā N̦ujorkā publicēja izdevumu "Nozaru iekšējais audits" (Internal Audit in Industry), kas ir IAI Pētījumu komitejas projekts divu gadu garumā; šīs publikācijas redaktori bija V. Z. Brink un B. Cadmus ${ }^{9}$. Publikācijā ietvertas dažādas nozares, kuras pārstāv speciāli veidotas komitejas un apakškomitejas ar atbilstošo nozaru speciālistiem. Pētijumā ir aplūkoti kontroles vispārīgie elementi, dažādas ražošanas un ieguves, kā arī pakalpojumu nozares - banku darbība, apdrošināšana, komunālie pakalpojumi, universālveikali, veikalu ķēdes un gaisa transports. Valsts pārvaldes funkcijas šajā pētijumā netika iekḷautas.

L. B. Sawyer (1911-2002), kurš tiek dēvēts arī par "modernā iekšèjā audita tēvu", darbu "The Practice of Modern Internal Auditing" pirmo reizi publicēja 1973. gadā, pēc tam atkārtoti kopā ar citiem autoriem - 1988., 1990., 1996. ${ }^{10}$,

6 Brink V. Z. (1943) Managerial control through internal auditing. La Salle extension university, 55 p.

7 Iekšējo auditoru institūta misija, vēsture. Pieejams: https://na.theiia.org/about-us/Pages/About-TheInstitute-of-Internal-Auditors.aspx [skatits 04.11.2018.]

8 Ramamoorti S. (2003) Chapter 1: Internal Auditing: History, Evolution, and Prospects. The IIA Research Foundation, Altamonte Springs, Florida, pp. 2-14.

9 Brink V. Z., Cadmus B. (1950) Internal auditing in industry. Developed under the direction of the Research Committee, $404 \mathrm{p}$.

${ }^{10}$ Sawyer L. B., Dittenhofer M. A. (1996) Sawyer's internal auditing: the practice of modern internal auditing. Altamonte Springs, Fla.: Institute of Internal Auditors, 1499 p. 
2005. un 2012. gadā. Pēdējā izdevumā ir trīs daļas: 1) Iekšèjā audita būtība; 2) Iekšèjā audita process un metodes; 3) Pārvaldība, risku vadība, atbilstības būtība. IAI pārstāvji raksturo L. B. Sawyer kā "profesijas sapņotāju”, jo viņš uzskatīja, ka iekšêjais auditors var attīstīties, tikai darbojoties iekšêjā audita jomā. Katra nākamā L. B. Sawyer publikācija ir papildināta ar jaunākajiem prakses piemēriem.

M. A. Dittenhofer (1914-2016) ir viens no iekšējo auditoru izglītošanas pamatlicējiem. Viņš kḷuva par vienu no L. B. Sawyer "Iekšêjā audita" 1446 lappušu biezās rokasgrāmatas redaktoriem, kā arī izveidoja iekšèjā audita izglìtības sadarbību, kas pašlaik notiek starp 45 koledžām un universitātēm dažādās pasaules valstīs. M. A. Dittenhofer ir 40 dažādu rakstu autors, viņa krājumā ir neskaitāmas prezentācijas konferencēs un ievērojams skaits grāmatu par iekšējā audita tēmām.

1976. gadā IAI ietvaros tika izveidots IAI pètijumu fonds (turpmāk IAIPF), kas konsekventi nosaka IA profesijas profesionālo sasniegumu standartu. Tā ir organizācija, kas izveidota, lai sniegtu un paplašinātu pētniecỉbu un iekšējo auditoru izglītošanu par IA profesijas, biznesa un valsts institūcijām, ziņojot par to plašai sabiedrībai. IAIPF ir pasaules līderis sponsorēšanā, izplatot un veicinot pētniecības un zināšanu resursus, lai stimulētu IA profesijas attīstību un efektivitāti. IAIPF galvenie mērḳi ${ }^{11}$, pēc autores domām, ir šādi:

1) nodrošināt iekšējos auditorus ar zināšanām un inovatīvām atziṇām, gatavojot publikācijas;

2) veicināt uzlabojumus, izmantojot aktuālos jautājumus, kas interesē auditorus.

1992. gadā tika izdots COSO (The Committee of Sponsoring Organizations of the Treadway Commission) vienotais iekšejāa kontroles modelis (framework) ${ }^{12}$, kas noteica, ka efektīva iekšējās kontroles sistēma ietver piecus elementus: kontroles vidi, risku novērtēšanu, kontroles darbības, informāciju un komunikāciju un uzraudzību. Modelis noteica, ka iekšêjā kontrole ir process, ko ietekmē vadība un darbinieki un kas izveidots ar mērḳi sniegt pietiekamu pārliecību par iestādes mērķu sasniegšanu trijās kategorijās: darỉjumu efektivitāte un lietderība; uzticiba finanšu atskaišu sagatavošanai; atbilstỉba likumiem un noteikumiem.

Autore uzskata, ka, tā kā iekšējā audita galvenais uzdevums ir sniegt novērtējumu par iekšêjās kontroles efektivitāti, šis notikums noteica skaidrākas

${ }^{11}$ Iekšējo auditoru institūta misija, vēsture. Pieejams: https://na.theiia.org/about-us/Pages/About-TheInstitute-of-Internal-Auditors.aspx [skatits 08.05.2015.]

${ }_{12}$ About COSO. Available at: http://info.knowledgeleader.com/bid/161685/what-are-the-five-components-of-the-coso-framework [cited 23.02.2018.] 
vadlīnijas iekšêjās kontroles sistematizēšanai un arī iekšèjā audita plānu sagatavošanai, un piekrìt H. Kagerman u. c., kas darbā "Internal Audit Handbook"13 uzsver, ka COSO iedarbināja koncepciju un kritērijus, kā iekšèjā audita funkcijai jādarbojas praktiski.

R. Šulca ${ }^{14}$ secinājusi, ka līdztekus ekonomikai pakāpeniski, bet sistemātiski ir attīstījies arī iekšējais audits, un izdalījusi septiņus vēsturiskos posmus:

1) audita pirmsākumi un termina "auditus" lietošana (3500 g. p.m.ē.);

2) audita kā profesijas pirmsākumi (13. gs.);

3) mūsdienu audita pirmsākumi (16.-17. gs.);

4) tiesisko aktu izveides pirmsākumi (19. gs.);

5) audita metodologijas pirmsākumi (pēc Pirmā pasaules kara);

6) IAI izveide un darbības uzsākšana (1941.-20. gs. 80. gadu beigas);

7) iekšèjā audita definēšana, tā tiesiskais un institucionālais regulējums (no 20. gs. 90. gadu sākuma līdz mūsdienām).

Autore šim dalïjumam piekrīt daļēji, jo, pētot zinātnisko literatūru un vēsturiskos faktus, ir konstatējusi, ka IA pirmsākumus vairāki pētnieki aprakstỉjuši senāk. Autore, pētot IAI vēsturiskos datus, konstatējusi, ka iekšējā auditora atbildību IAI formulējis 1947. gadā un IA definīcija publicēta 1978. gadā (sk. 1.1. un 1.3. tabulu). Pirmās publikācijas par IA parādās jau 1904. gadā Lielbritānijā, līdz ar to iekšêjā audita metodolog̣ijas pirmsākumi ir datējami ar šo periodu, nevis pēc Pirmā pasaules kara.

Pamatojoties uz zinātniskiem pētījumiem, ekonomiskās literatūras analīzi un vēsturiskajiem ekonomikas notikumiem pasaulē, IA attīstība iedalāma trīs nozīmīgās fāzēs, kas savukārt iedalās vairākos secīgos periodos jeb posmos (sk. 1.1. tabulu):

1) iekšèjā audita pirmsākumi (no 4000. g. p.m.ē. līdz 1940. gadam), kas ietver IA attīstîbu ietekmējošos un saistošos notikumus pasaulē pirms IAI dibināšanas;

2) globālā IA iezīmes, IAI dibināšana un vēsturiskā attīstība (1941-1999);

3) IT periods (kopš 2000. gada), kad virtuālā vide un komunikācija e-vidē ir noteicošā vadības procesos, t. sk. arī IA funkcijas kvalitāte ir atkarīga no IT. Šajā periodā sākas ES paplašināšanās un jaunās kandidātvalstis ievieš IA kā vienu no obligātajām prasībām.

\footnotetext{
${ }^{13}$ Kagerman H. et al. (2008) Internal Audit Hanbook. Sprinfer, Germany, p. 608.

${ }^{14}$ Šulca R. (2010) Latvijas pašvaldību iekšèjā audita sistēmas attīstības iespējas. Pētījuma kopsavilkums. Jelgava, 131. lpp.
} 
1.1. tabula. lekšējā audita vēsturiskā attīstība

\begin{tabular}{|c|c|c|c|}
\hline Periods & Vieta & lekšējā audita attīstības būtiskākie notikumi & $\begin{array}{l}\text { lekšējā audita nozīmes } \\
\text { maiṇa }\end{array}$ \\
\hline \multicolumn{3}{|c|}{ 1. fāze. lekšējā audita pirmsākumi } & Tāla pagātne \\
\hline $\begin{array}{l}\text { 4000.- } \\
3500 . \\
\text { p.m.ē. }\end{array}$ & $\begin{array}{l}\text { Tuvie } \\
\text { Austrumi }\end{array}$ & $\begin{array}{c}\text { Formālas uzskaites sistēmas rašanās, bažas } \\
\text { par pareizu ieņēmumu, izdevumu un nodokḷu } \\
\text { iekasēšanu }\end{array}$ & \multirow{5}{*}{$\begin{array}{c}\text { lekšējais auditors - } \\
\text { grāmatvedis-eksperts; } \\
\text { pārrakstīšanas } \\
\text { palīgstrādnieks; } \\
\text { rezerves darbinieks; } \\
\text { krāpšanās izmeklētājs; } \\
\text { pārbaudītājs. }\end{array}$} \\
\hline \multirow[t]{2}{*}{ 13. gs. } & \multirow[t]{2}{*}{ Eiropa, Itālija } & $\begin{array}{c}\text { Divkāršã ieraksta sistēmas rašanās, kritiska } \\
\text { nepieciešamība pēc pārvaldnieku darba } \\
\text { pārbaudes un kontroles }\end{array}$ & \\
\hline & & Pirmie valsts iekšējie auditori & \\
\hline $\begin{array}{l}\text { 18. gs.- } \\
\text { 19. gs. }\end{array}$ & ASV, Eiropa & $\begin{array}{c}\text { "Dienvidu jūras burbulis", "Tulpju skandāls", } \\
\text { dzelzceḷu attīstība } \\
\text { Lielākas vadītāju kontroles izplatīšanās }\end{array}$ & \\
\hline $\begin{array}{l}\text { 1904.- } \\
1940 .\end{array}$ & Lielbritānija & $\begin{array}{c}\text { A. Collins pirmās publikācijas par pilnu } \\
\text { pašvaldību ieñēmumu IA nozīmīgākajās } \\
\text { pašvaldībās }\end{array}$ & \\
\hline \multicolumn{3}{|c|}{$\begin{array}{l}\text { 2. fāze. Globālā iekšējā audita iezīmes, IAl dibināšana un vēsturiskā } \\
\text { attīstība }\end{array}$} & Pagātne \\
\hline 1941. & ASV & IAl izveidošana un dibināšana & \multirow{8}{*}{$\begin{array}{c}\text { lekšējais auditors - } \\
\text { operatīvās darbības } \\
\text { auditors, kas paklauts } \\
\text { ārējam auditoram. } \\
\text { Kopš 1993. gada IA } \\
\text { pienākumi - audita } \\
\text { apjoms, organizācijas } \\
\text { iekšējās kontroles } \\
\text { sistēmas atbilstības } \\
\text { un efektivitātes } \\
\text { novērtējums. }\end{array}$} \\
\hline $\begin{array}{l}\text { 1947.- } \\
1957 .\end{array}$ & $|A|$ & $\begin{array}{l}\text { lekšējā audita pienākumu definēšana un } \\
\text { papildināšana }\end{array}$ & \\
\hline 1958. & $|A|$ & $\begin{array}{c}\text { IA definīcija - galvenais uzsvars ir operativie } \\
\text { darbības auditi }\end{array}$ & \\
\hline 1968. & $|A|$ & Vadlīnijas auditoriem un Ëtikas kodekss & \\
\hline 1972. & $|A|$ & $\begin{array}{l}\text { CBOK publikācijas un iekšējo auditoru } \\
\text { sertifikācijas (CIA) ieviešana }\end{array}$ & \\
\hline 1976. & ASV, IAI & IAIPF izveidošana & \\
\hline 1978. & $|A|$ & $\begin{array}{l}\text { IA definīcija, IA profesionālās prakses } \\
\text { starptautisko standartu (Standartu) } \\
\text { apstiprināšana, kas ir nemainīgi } 20 \text { gadus }\end{array}$ & \\
\hline $\begin{array}{l}\text { 1985.- } \\
1993 .\end{array}$ & ASV & $\begin{array}{c}\text { COSO dibināšana, } \\
\text { lekšējās kontroles integrētās sistēmas } \\
\text { publicēšana }\end{array}$ & \\
\hline 1999. & $\mathrm{IAI}$ & IA definīcija, kas balstīta uz riska novērtējumu & \\
\hline \multicolumn{3}{|c|}{$\begin{array}{l}\text { 3. fāze. 21. gs., IT periods: prasība iekšējam auditoram - pilnīga virtuālā } \\
\text { auditēšana }\end{array}$} & Tagadne \\
\hline $\begin{array}{l}\text { 2000.- } \\
2002 .\end{array}$ & $\begin{array}{l}\text { ASV } \\
\text { Eiropa }\end{array}$ & $\begin{array}{c}\text { Sorbanes-Oxley akts, valsts uzñēmumu } \\
\text { grāmatvedības reforma un investoru protests, } \\
\text { jauni IAI standarti, ES izvirzītās prasības } \\
\text { jaunajām ES kandidātvalstīm }\end{array}$ & \multirow{4}{*}{$\begin{array}{c}\text { (1992. gadā autori šo } \\
\text { posmu klasificē kā } \\
\text { nākotni.) } \\
\text { lekšējais auditors - } \\
\text { vadības partneris; IT } \\
\text { sistēmu novērtētājs; } \\
\text { izmaksu sistēmu } \\
\text { vērtētājs; } \\
\text { aktīvs auditors, kas } \\
\text { sadarbojas ar ārējo } \\
\text { auditoru. }\end{array}$} \\
\hline $\begin{array}{l}2003 ., \\
2008 .\end{array}$ & $|A|$ & $\begin{array}{c}\text { Jaunās iekšējā audita definīcijas } \\
\text { 2006. gads - globālie standarti, kas tulkoti } 32 \\
\text { valodās }\end{array}$ & \\
\hline $\begin{array}{l}\text { 2009.- } \\
2012 .\end{array}$ & $|A|$ & Pārskatīti Standarti $(2009,2012)$ & \\
\hline $\begin{array}{l}\text { 2013.- } \\
2017 .\end{array}$ & $\begin{array}{l}\text { Visa pasaule, } \\
\text { IAIPF }\end{array}$ & $\begin{array}{c}\text { Pētījumi par iekšējā audita attīstību pasaulē, } \\
\text { publikācijas }\end{array}$ & \\
\hline
\end{tabular}

Avots: autores veidota tabula pēc Brink, Cadmus (1950), Ramamoorti (2003), Anderson (2010), IAI (2015), Gupta, Ray (1992), Vērdiña (2012). 
Daudzi pētnieki un profesionāļi uzskata, ka modernais IA radies 1941. gadā, kad izveidojās IAI, kura uzdevums bija popularizēt profesiju, kas būtiski atšķiras no ārējā audita (ārējās revīzijas).

N̦emot vērā faktu, ka IAI 1941. gadā ir dibināts ASV, lielu ietekmi IA attīstībā devuši ekonomiskie un finanšu vēsturiskie notikumi tieši ASV, kas saistīti gan ar nopietnām izmain̄ām normatīvajos aktos (Sarbanes-Oxley Act), gan citu profesionālo organizāciju veidošanos, piemēram, IAIPF, COSO, gan globālo IT progresu 21. gadsimta sākumā, kas vēsturē iezīmēja neatgriezenisku izaugsmes iespēju iekšèjā audita profesijai. Informācijas tehnolog̣iju attīstìbai, informācijas apjoma pieplūdumam, interneta laikmetam un paātrinātai komunikācijai ir bijusi l̦oti liela nozīme globalizācijas procesos. Vadīšanas, risku, kontroḷu un atbilstības principi iestādē ir pakḷauti nozīmīgām izmaiṇām, kas iekšejā audita funkcijai sniedz iespējas arvien vairāk attīstīties.

Pēc IA attīstības analīzes autore secina, ka par šīs profesijas pamatlicējiem vēsturiski var uzskatīt gan IA praktiķus, gan zinātniekus, kas veidojuši pirmās nozīmīgās publikācijas par šo jomu. Autores ieskatā, būtisku ieguldījumu devuši A. Collins un C. A. Smith, kā arī IAI dibinātāji ASV - J. B. Thurston, R. B. Milne un V. Z. Brink.

Daudzi autori, piemēram, A. Collins kopš 1904. gada, C. A. Smith kopš 1933. gada, V. Z. Brink kopš 1941. gada, L. B. Sawyer kopš 1973. gada, P. P. Gupta un M. R. Ray 1992. gadā, S. Ramamoorti, W. O. Baggett 2003. gadā, H. Kagerman u. c. 2008. gadā, A. D. Chambers 2015. gadā, C. Guillot 2016. gadā savos darbos ir aprakstijjuši IA vēsturisko attīstību, IA lomas un kompetences dažādos periodos, veidojuši praktiskās iekšējo auditoru rokasgrāmatas. W. H. A. Swinkels 2012. gadā savu disertāciju Nìderlandē veltījis iekšejjā audita teorijas izpētei. A. P. Burnaby, S. Hass, G. Sarens u. c. 2011. gadā veikuši detalizētu IA funkcijas analizzi, pamatojoties uz IAIPF veikto CBOK aptauju datiem kopš 2010. gada, kurā autori secinājuši, ka iekšêjo auditu var iedalīt divos galvenajos līmeņos:

1) makro jeb valstu līmenī - IA profesijas dažādība redzama brīdī, kad salīdzina pasaules valstis. Zinātnieki kā vienu no iemesliem min kultūras atšķirīibas un ekonomiskās attīstîbas pakāpes (piemēram, valsts iekšzemes kopprodukta rādītāju), kas ietekmē IA izveidi un attīstību konkrētā valstī kopumā;

2) mikro jeb organizācijas līmenī - individuāli atšķirīga IA funkcija vai departaments. Ir veikti pētỉjumi, kas atklāj iemeslus, kāpēc organizācija izveido IA, kā arī pēta iekšējā audita pastāvēšanu un IA funkcijas lielumu un specifiku.

IA loma gadu gaitā ir krasi mainïjusies, taču nemainīga ir palikusi būtỉba rast pārliecību par iestādes darbības efektīvu un ekonomisku IKS novērtēšanu. 


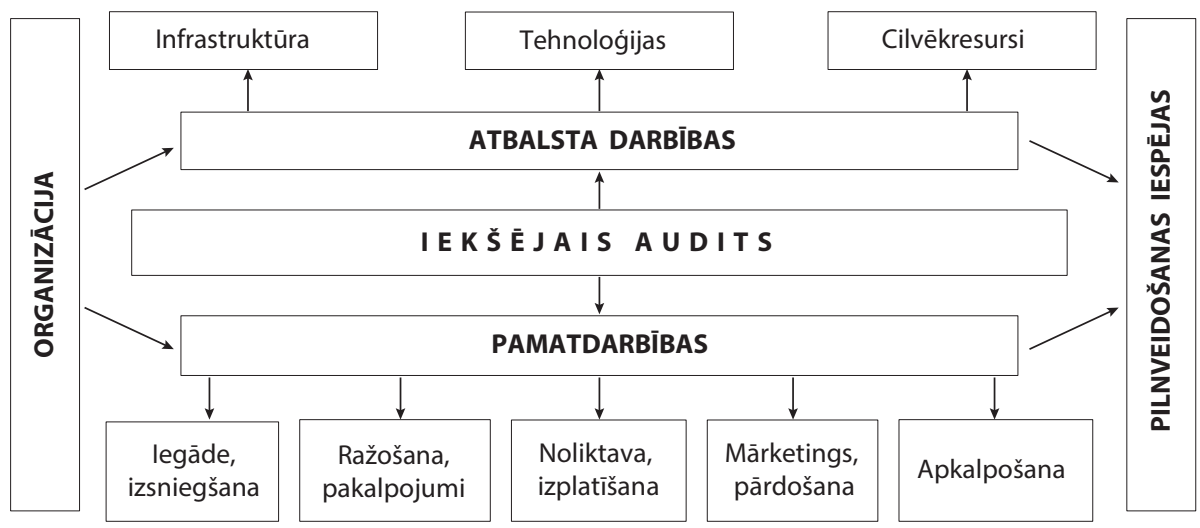

\section{1. attēls. lekšējā audita loma vērtību ḳēdē}

Avots: autores veidota shēma, pamatojoties uz Ray (2009).

Katras iestādes ziṇā paliek IA lomas būtiskums, iekšējo auditoru ziņā - metodes, ar kādām tiek strādāts, lai šo pārliecību sniegtu ziṇojumā. Kā viens no variantiem IA lomas atspoguḷošanai iespējams E. Ray $y^{15}$ piemērs (1.1. attēls), kas savu viedokli pamato ar klasisko Portera darbu "Konkurences priekšrocības" un parāda, ka iestādei ir divas būtiskas kategorijas, kuras rada pievienoto vērtību, - primārās (pamata) darbības un sekundārās (atbalsta) darbības. Pamata darbības ietver iestādes ikdienas operatīvo vadību, savukārt atbalsta aktivitātes ietver stratēǵisko plānošanu, finanses un juridiskos pakalpojumus, pētniecību, tāpat arī cilvēkresursu vadību un attīstību. Lai IA izpilde būtu efektīva, IA plānam jābūt saistìtam ar visu 1.1. attēlā minēto darbību (funkciju) mērķiem. Kad atbalsts un galvenās (pamata) darbības organizācijā tiek veiktas efektīvi, iespējas var tikt paplašinātas un iestāde var gūt konkurētspējas priekšrocības. Tas apstiprina ideju, ka IA sniedz organizācijai pievienoto vērtību un palīdz veiksmīgāk izpildìt stratēgiju, radot papildu iespējas, kā sasniegt organizācijas mērķus.

${ }^{15}$ Ray E. Adding Value: How Modern Internal Auditing Assists Organizations in Achieving Strategic Objectives. IIARF, 2009, pp. 4-5. 


\section{2. lekšējā audita jaunākie pētỉjumi}

Pamatojoties uz zinātniskās literatūras analīzi, šajā apakšnodal̦ā ir veidots IA teorētiskais apskats par jaunākajiem pētījumiem IA jomā.

Iekšējais audits ne tikai kontrolē darbības procesu norises sabiedrībā (iestādē), bet arī vienlaikus "spēlē noteicošo lomu" risku vadīšanas procesā noteiktās jomās, kurās tas jāuzlabo. ${ }^{16}$ Iekšèjā audita darba apjoms ietver visas organizatoriskās darbības, visus vadības uzdevumus, visu veidu kontroles, visus biznesa jautājumus un riska veidus. Tādējādi IA neaprobežojas nedz ar finanšu darbībām un procedūrām, nedz arī risku kḷūdīties vai pieḷaut finansiālu kḷūdu. ${ }^{17}$

Autore secinājusi, ka zinātnieki un profesionāḷi IA pētījumos izmanto vēsturisko analīzi, filozofisko pieeju, ekonomiskos modẹı un matemātiskos un statistiskos aprēḳinus un analīzi, tāpat tiek izmantotas gan aptaujas, gan ekspertu metodes.

Apkopojot IA pētỉjumus, autore savā pētījumā ietver vispārīgos IA funkcijas pētījumus un ar publisko sektoru saistītos jaunākos zinātniskos tematus.

Iekšèjā audita kvalitāti un tās ietekmējošos faktorus pētījuši vairāki Āfrikas un ASV autori, piemēram, P. Coetzee, H. Fourie, P. A. Burnaby. ${ }^{18}$ Autori, izmantojot CBOK 2006. un 2010. gada aptauju datus, ir koncentrējušies uz jautājumiem, kas skar IA kvalitāti un to noteicošos faktorus un rādītājus. Tika pētītas Dienvidāfrikas un citu valstu respondentu viedokḷu atšksirības un secināts, ka nav atškirīibu starp Āfrikas un citu valstu auditoru izglïtības un pieredzes līmeni, tāpat sertificēto auditoru skaits 2010. gadā, pretēji citu valstu datiem, ir pieaudzis. Autori secina, ka audita kvalitāti nevar noteikt pèc CBOK aptauju datiem, kurās atbildes sniedz tikai IA veicēji, un ka IAI biedru skaits var būt arī kā iekšējā audita kvalitāti uzlabojošs rādītājs. Lìdzīgi D. S. B. Soh un N. Martinov-Benie ${ }^{19}$ ir pētijjuši iekšèjā audita lomu, efektivitāti un novērtējumu, uzsverot, cik svarīgi ir tas, lai iekšējā audita funkcija spētu sniegt ieguldījumu kvalitātes un korporatīvās pārvaldības jomā, izmantojot pārraudzības lomu, veicinot uzlabojumus kontroles un uzraudzības vidē, kā arī lai mazinātu potenciālo krāpšanas risku, pētỉjumu balstot uz anonīmu aptauju, kurā piedalìjās

\footnotetext{
${ }^{16}$ Baggett W. O. (2003) Creating a Culture of Security. Internal Auditor, June, p. 3.

${ }^{17}$ Wade K. W. (2001) Iekšējā audita apjoms. Grāmatvedība un revīzija, 2001/5, 11. lpp.

${ }^{18}$ Coetzee P., Fourie H. \& Burnaby P. A. (2015) The growth of the internal audit profession is more than just numbers. Fact or fiction? Evidence from South Africa. Managerial Auditing Journal, Vol. 30 No. 6/7, pp. 514-538. Available at: www.emeraldinsight.com [cited 25.07.2016.]

${ }^{19}$ Soh D. S. B. and Martinov-Bennie N. (2011) The internal audit function. Perceptions of internal audit roles, effectiveness and evaluation. Managerial Auditing Journal, Vol. 27, No. 7, pp. 605-622.
} 
seši lielākie Austrālijas uzṇēmumi un viena publiskā sektora iestāde. Autori pētījumā konstatēja, ka neatbilstība starp iekšējā audita lomu un novērtēšanu rada grūtības, nosakot, cik lielā mērā iekšejāa audita funkcijas atbilst ieinteresēto personu cerībām.

Rumāṇu pētniece C. L. Nedea ${ }^{20}$ uzskata, ka iekšējais audits publiskajā sektorā pēdējā laikā arvien attīstās, kaut gan saglabājas problēmas darbības un organizatoriskajā jomā. Vairāki autori ir pētijjuši iekšējā un ārējā audita sadarbību publiskajā sektorā, piemēram, komunikācijas barjeras ${ }^{21}$ Austrālijā, un arī Eiropas Komisijas kopējā ziņojumā par 27 dalībvalstīm 2012. un 2014. gadā. Svarīgākās problēmas, ko autori uzsver - nenotiek informācijas apmaiņa starp iekšèjiem un ārējiem auditoriem, līdz ar to palielinās auditējamo slodze, netiek ieviestas audita komitejas kā iekšējā audita uzraugošā institūcija.

Salīdzinoši jaunākā J. Pelletier un V. Tophoff 2016. gada publikācija pētījumā par pārvaldību publiskajā sektorā atklāj, kā iekšējie auditori var īstenot starptautisko ietvaru: International Framework: Good Governace in the Public Sector un Chartered Institute of Public Finance and Accountancy ${ }^{22}$. Darbā ir akcentēts, kā nodrošināt labāku pārvaldību publiskajā sektorā un ka IA ir labas pārvaldības stūrakmens.

IT nozīmīgo lomu iekšèjā auditora darbā pētījuši vairāki autori, piemēram, M. Abdolmohammadi u. c. ${ }^{23}$ 2016. gadā analizējuši IT izmantošanu iekšèjo auditoru darbā pasaulē pēc 2015. gada CBOK aptaujas datiem, saskatot atškirīibas gan tehnoloǵiju izmantošanā, gan dažādu programmatūru lietošanā IA procesos un saistot rezultātus ar IAS vecumu, dažādu līmeņu IA un vadības darbinieku statusu iestādes struktūrā, iestādes nodarbināto skaitu, kā arī vērtējuši datus atbilstoši pasaules reǵioniem.

Autore pētījumā iekḷauto literatūru ir apkopojusi sadalījumā pa IA procesiem (1.2. tabula), sagrupējot zinātniskās publikācijas par IA un tā elementiem vairākās kategorijās.

${ }^{20}$ Nedea C. L. (2015) The Role and Prospects of the Internal Audit in Improving management of Public Institutions. Valahian Journal of Economic Studies, Vol. 6(20), Issue 3, pp. 7-14.

${ }^{21}$ Pilcher R. et al. (2013) The Interface between Internal and External Audit in the Australian Public Sector. Australian Accounting Review, No. 67, Vol. 23, Issue 4, pp. 330-340.

${ }^{22}$ Pelletier J., Tophoff V. (2016) Inspire, Implement, Assure - How Internal Auditors Can Leverage the International Framework Good Governance in The Public Sector. Oct., 11. Available at: https://www.ifac.org/global-knowledge-gateway/governance/discussion/inspire-implementassure-how-internal-auditors-can [cited 25.01.2017.]

${ }^{23}$ Abdolmohammadi M., D’onza G., Sarens G. (2016) Bechmarking Internal Audit Maturity. CBOK IIARF, pp. 43. Available at: www.theiia.org/gotoCBOK [cited 03.08.2016.] 
1.2. tabula. Zinātniskās un praktiskās iekšējā audita literatūras grupas

(20. gs.-2018. gads)

\begin{tabular}{|c|c|c|}
\hline $\begin{array}{l}\text { lekšējā audita } \\
\text { process }\end{array}$ & Autors(-i), gads & Pētījuma galvenie jautājumi \\
\hline $\begin{array}{l}\text { lekšējā audita } \\
\text { metodika }\end{array}$ & $\begin{array}{l}\text { EK ziņojums }(2012,2014) \\
\text { Chambers A. D. }(2015,2016) \\
\text { IAIPF pētījumi }(2006,2010,2015) \\
\text { Niekwlands H. }(2006) \\
\text { Public Sector Internal Audit } \\
\text { Standards (2013) }\end{array}$ & $\begin{array}{l}\text { Standarti, definīcija, IA veikšanas metodes, pieejas, } \\
\text { darba dokumentu piemēru un paraugu analīze. } \\
\text { Pētījumi, kas parāda IA funkcijas nozīmīgo lomu } \\
\text { normatīvo aktu regulējumā ASV, Lielbritānijā un } \\
\text { Austrālijā. }\end{array}$ \\
\hline $\begin{array}{l}\text { lekšējā audita } \\
\text { pievienotā } \\
\text { vērtība }\end{array}$ & $\begin{array}{l}\text { Diamond J. (2002), Piper A. (2015) } \\
\text { Ray E. (2009) } \\
\text { Rouzs Dž. (2013) } \\
\text { Globālais ziņojums (2014) } \\
\text { Abdolmohammadi M. et al., } \\
\text { IAIPF (2016) } \\
\text { Sarens G., Lamboglia R. (2013) } \\
\text { Soh D. S. B., Martinov-Bennie N. } \\
\text { (2011) }\end{array}$ & $\begin{array}{l}\text { IA loma publiskajā pārvaldē, } \\
\text { IA vieta un loma iestādes struktūrā, } \\
\text { IA loma un atbildība, efektivitāte un } \\
\text { novērtēšana - novirzes starp lomu un novērtēšanu. } \\
\text { Brieduma modẹ̄i - pārliecības gūšana un } \\
\text { konsultācijas, kā IA virzienu maiṇa ietekmē } \\
\text { iestādes pievienoto vērtību. } \\
\text { 2015. gada CBOK pasaules iekšējo auditoru } \\
\text { aptaujas analīze - risku vadība, audita procedūras } \\
\text { u. c. } \\
\text { lekšējo auditoru atbilstība Standartiem. }\end{array}$ \\
\hline $\begin{array}{l}\text { Audita } \\
\text { komitejas loma } \\
\text { IA veiksmīgā } \\
\text { darbībā }\end{array}$ & $\begin{array}{l}\text { Davies M. (2009), IIARF White paper } \\
\text { (2013), Zaman M., Sarens G. (2013) } \\
\text { KPMG (2013), } \\
\text { IIAFR pētijumi (2010, 2015), } \\
\text { PIC in the EU (2014) }\end{array}$ & $\begin{array}{l}\text { IA un audita komiteju efektīva sadarbība } \\
\text { pašvaldībās Velsā, Lielbritānijā. } \\
\text { IAS vadītāja un audita komitejas sadarbība; } \\
\text { neoficiālas sadarbības iespējas, audita komitejas } \\
\text { mērkisis, IA komitejas loma IA vērtēšanā. }\end{array}$ \\
\hline $\begin{array}{l}\text { lekšējā audita } \\
\text { novērtēšana }\end{array}$ & $\begin{array}{l}\text { Dubis G. S., Jain P., Manchanda A., } \\
\text { Thakkar R. (2010) } \\
\text { KPMG (2003) } \\
\text { Marks N. (2018) } \\
\text { IAIPF CBOK (2010, 2015.) } \\
\text { Chen J.-F., Lin W.-Y. (2011) }\end{array}$ & $\begin{array}{l}\text { IA efektivitātes un lietderības vērtēšana, dažādu } \\
\text { anketu piemēri. } \\
\text { IA vērtēšanas anketas, nodalot IA komitejas } \\
\text { vērtējumu, ārējā audita vērtējumu, vadības } \\
\text { vērtējumu, tāpat arī IA pašnovērtējumu. } \\
\text { IA efektivitātes vērtēšana. } \\
\text { IA vērtības mērīšanas sistēma. }\end{array}$ \\
\hline $\begin{array}{l}\text { lekšējā audita } \\
\text { efektivitāte } \\
\text { lekšējā audita } \\
\text { filozofija }\end{array}$ & $\begin{array}{l}\text { Lenz R., Hahn U. (2015) } \\
\text { Parker G. W. (1995), } \\
\text { MacRae E. (2014) } \\
\text { Norman C. S. et al. (2009) } \\
\text { Sawyer L. B. (1995) } \\
\text { Ramamoorti S., Siegfried A. N., } \\
\text { IAIPF (2016) } \\
\text { Harrington L., Piper A., IAIPF (2016) } \\
\text { Coetzee P. et al. (2015) }\end{array}$ & $\begin{array}{l}\text { Empīriski pētījumi IA efektivitātes noteikšanai } \\
\text { akadēmiskajā literatūrā. } \\
\text { IA un krāpšanās riska analīze, IA profesijas } \\
\text { svarīgākie elementi, IA misijas, stratēǵijas, audita } \\
\text { kultūras analīze pasaulē. } \\
\text { IA un risku vadība, audita komiteju nozīme, } \\
\text { standartu loma IA darbā, iekšējo auditoru izglītība. } \\
\text { lekšējā audita profesijas raksturojums, IAIPF } \\
\text { pētījuma kritiska analīze par Dienvidāfrikas } \\
\text { datiem. }\end{array}$ \\
\hline $\begin{array}{l}\text { lekšējā audita } \\
\text { definīcijas }\end{array}$ & $\begin{array}{l}\text { AkadTerm datubāze, } \\
\text { Skujiṇa V. (2010); Ekonomisko } \\
\text { terminu vārdnīca (1997); } \\
\text { Ekonomikas un finanšu vārdnīca } \\
\text { (2003); Ekonomikas skaidrojošā } \\
\text { vārdnīca (2000) } \\
\text { IAI (1999, 2008), Mālderis G. (2008) } \\
\text { Šulca R. (2010) } \\
\text { Latvijas Republikas normatīvie akti }\end{array}$ & $\begin{array}{l}\text { IA definīcijas izmaiņas un atšksirības standartos un } \\
\text { ekonomikas literatūrā. }\end{array}$ \\
\hline
\end{tabular}




\begin{tabular}{|c|c|c|}
\hline $\begin{array}{c}\text { lekšējā audita } \\
\text { process }\end{array}$ & Autors(-i), gads & Pētījuma galvenie jautājumi \\
\hline $\begin{array}{l}\text { Latvijas } \\
\text { iekšējā audita } \\
\text { attīstības } \\
\text { pētījumi }\end{array}$ & $\begin{array}{l}\text { Blažēvica I. (2000) } \\
\text { Grūba I. (2010) } \\
\text { Šulca R. (2010) } \\
\text { Vērdiṇa G. (2012) } \\
\text { Brūna I. (2010, 2014) } \\
\text { Faituša I. (kopš 2010. gada) } \\
\text { Ivanova I. (2014, 2016) } \\
\text { Finanšu ministrija }\end{array}$ & $\begin{array}{l}\text { Kontroles pašnovērtējums - viena no IA metodēm. } \\
\text { IA nodošana ārpakalpojumā - plusi un mīnusi. } \\
\text { Pašvaldību IA attīstība. } \\
\text { IK aspekti, ieklıujot IA. } \\
\text { IA Baltijas valstīs u. c. } \\
\text { Valsts pārvaldes un pašvaldību IA iespējas, ES } \\
\text { valstu salīdzinājums. } \\
\text { IAI pieeju analīze, IAIPF pētījumi, intervijas ar } \\
\text { profesionāliem. } \\
\text { Ikgadējie analītiskie ziņojumi par valsts pārvaldes } \\
\text { IA paveikto. }\end{array}$ \\
\hline $\begin{array}{l}\text { lekšēja audita } \\
\text { un ārējā audita } \\
\text { sadarbība }\end{array}$ & $\begin{array}{l}\text { Diamond (2002) } \\
\text { IIAFR pētījumi }(2006,2010,2015) \\
\text { EK zin,ojums }(2012,2014) \\
\text { LR VK (2014), Sudraba I. (2012) } \\
\text { ECIIA vadlīnijas (2010.) } \\
\text { Zammit, Baldacchino (2012) } \\
\text { ECIIA (2013) } \\
\text { Chartered Institute of Internal } \\
\text { Auditors (2017) }\end{array}$ & $\begin{array}{l}\text { Rekomendācijas IA un ārējā audita sadarbībai. } \\
\text { IA jomas pārstāvju viedokḷu salīdzinājums dažādos } \\
\text { gados dažādās pasaules valstīs ar vairākiem } \\
\text { tūkstošiem respondentu. } \\
\text { Maltas piemērs IA un ārējā audita sadarbībai, } \\
\text { izmantojot neformālu komunikāciju. } \\
\text { lekšējā un ārējā audita sadarbības uzlabošana, } \\
\text { piemērojot COSO riska vadības ietvaru. } \\
\text { Atšḳirīgās IA un ārējā audita lomas. }\end{array}$ \\
\hline
\end{tabular}

Avots: autores veidots saraksts, pamatojoties uz pētīto literatūru.

Būtiska uzmanība gan pasaules, gan Eiropas jaunākajos IA pētỉjumos veltìta IA efektivitātes mērīšanai un pievienotās vērtības analīzei. Nozīmīgākie IA vērtēšanas faktori pasaules pētnieku skatījumā ir starptautisko standartu izmantošana un ievērošana IA procesos, IA komitejas nozīmīgā loma IA procesā iestādē, efektīva iekšèjā un ārējā audita sadarbības organizēšana, publiskā sektora IA darbỉbu iekḷaušana normatĩvajos aktos, par ko liecina daudzi pētijumi (sk. 1.2. tabulu).

Starptautiskā auditorkompānija KPMG publicējusi viedokli, ka audita komitejai jāvērtē IA, pamatojoties uz savu pieredzi, tāpat jāpieprasa vadības un ārējā audita viedoklis par IA funkciju attiecīgajā iestādēên, uzsvērta arī IA pašnovērtējuma būtiskā nozīme un anketēšana kā novērtēšanas metode.

Risku speciālists N. Marks pauž viedokli, ka IA ir efektīvs, ja tas nodrošina audita komiteju un vadību ar pārliecību, kāda tiem nepieciešama, lai reageètu uz organizācijas procesiem un risku vadību, lai organizācija varētu sasniegt mērķus, nodrošinot pārliecību par pašreizējiem riskiem atbilstošā laikā un formā. ${ }^{25}$

\footnotetext{
${ }^{24}$ Audit Committee Institute. KPMG. Available at: www.kpmg.co.uk/aci [cited: 02.02.2018.]

${ }^{25}$ Marks N. (2018) How to Assess the Efectiveness of Internal Audit. Internal Auditor, 3 p.
} 
Audita komitejas mērḳis ir palīdzēt vadībai uzraudzības pienākumu veikšanā attiecībā uz finanšu ziņojumiem, iekšêjo kontroli, risku vadību, atbilstību, ētiku, vadību, IA un ārējo auditu. ${ }^{26}$

IAI pētniekiem ir viedoklis, ka IA vērtēěanas sistēmas pamatā ir IA vērtība, ko nosaka IA ieguldījums risku vadībā un kontroles procesos. To ietekmē:

- normativie akti;

- iestādes struktūra un audita komiteja;

- IA struktūrvienība (tās vēsture, stratēgiija, plānošana u. c.);

- IA standarti (to izmantošana, atbilstības līmenis, ārējais kvalitātes novērtējums);

- IA darbības (apjoms, ziņojuma saturs, komunikācija un atklājumi, ieteikumu ieviešanas uzraudzība);

- organizācija (reǵions, kopējais darbinieku skaits, aktīvu kopsumma, ieņēmumu kopsumma, veicamo darbību apjoms);

- respondentu raksturojums (vecums, dzimums, izglīiības līmenis, sertifikācija, pieredze, ziņošanas kārtība, regulāras mācības). ${ }^{27}$

2015. gada CBOK aptaujā tika analizēts IA regulējums normatīvajos aktos valsts sektorā (public sector). Dati parāda, ka Latīṇamerikā $88 \%$ no visām IAS iekšèjā audita regulējumu nosaka normatīvie akti, Āfrikā vidēji - 81\%, Amerikā $-62 \%$, Eiropā $-68 \%$ no IAS. Tāpat kopējie dati parāda, ka 71\% IAS vidēji pasaulē ir veidotas, pamatojoties uz normatīvajos aktos noteikto regulējumu.

Saskaņā ar iepriekš minēto autore, pētot ES valstis, tālāk grāmatas 1.4. apakšnodalıā kā IA vērtēšanas faktorus ir izvēlējušies normatīvo aktu sistēmu, IA komitejas darbību, iekšējo auditoru sertifikācijas prasības auditoriem un IA un ārējā audita sadarbību. Grāmatas 2. nodaḷā organizācijas ietekmējošos faktorus - organizācijas darbinieku skaitu, organizācijas aktīvu un ien̦ēmumu kopsummu - autore analizēs, pētot Latvijas pašvaldību IA sistēmu. Lai noskaidrotu iekšèjā audita pilnveidošanas iespējas Latvijas valsts tiešajā pārvaldē un pašvaldībās, darba autore veic pētijumu pēc noteiktas shēmas (1.2. attēls).

Pētījuma pirmajā posmā, izmantojot kvalitatīvo datu vākšanu, tiek veikta literatūras analīze, lai pamatotu IA nozīmīgo lomu, analizētu IA definīciju un attīstību. Nākamajā posmā, turpinot kvalitatīvo un kvantitatīvo datu analīzi ar

${ }^{26}$ Role of Audit Committees for IA in the public sector. Discussion paper No. 4 PIC an EU Approach, ref. 2014-4. Available at: http://ec.europa.eu/budget/pic/lib/docs/pic_paper4_en.pdf [cited: 24.02.2018.]

${ }^{27}$ Chen J.-F., Lin W.-F. (2011) Measuring Internal Auditing's Value. The IIA Global Audit Survey. A component of the CBOK Study. IIARF. pp. 1-2. 


\begin{tabular}{|c|c|c|c|c|c|}
\hline \multicolumn{2}{|c|}{$\begin{array}{c}\text { Kvalitatīvo datu vākšana } \\
\text { (1) }\end{array}$} & \multicolumn{2}{|c|}{$\begin{array}{c}\text { Kvalitatīvo un kvantitatīvo } \\
\text { datu analīze (2) }\end{array}$} & $\begin{array}{l}\text { Rezultāts } \\
\text { (3) }\end{array}$ & \multirow{2}{*}{$\begin{array}{c}\text { Darba } \\
\text { nodal’a } \\
\text { (4) }\end{array}$} \\
\hline Metode & Rezultāts & Metode & Rezultāts & Novitātes & \\
\hline 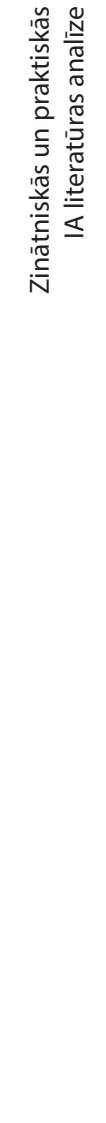 & $\begin{array}{l}\text { 1. IA rašanās, } \\
\text { IA vēsturiskās } \\
\text { attīstības fāžu } \\
\text { sadalījums. } \\
\text { 2. Teorētiskās } \\
\text { atziñas pasaules } \\
\text { pētījumos. } \\
\text { 3. IA attīstība } \\
\text { publiskajā } \\
\text { sektorā ES un } \\
\text { pasaulē. } \\
\text { 4. IA un risku } \\
\text { vadības sakarību } \\
\text { definēšana. }\end{array}$ & 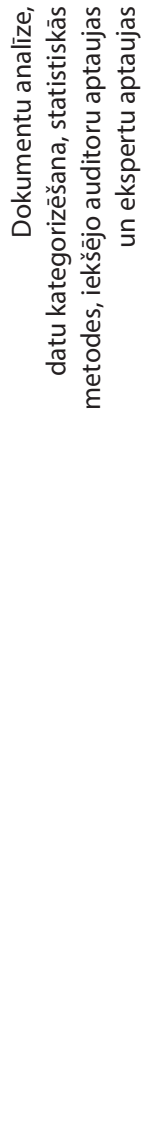 & $\begin{array}{l}\text { 1. Valsts tiešās } \\
\text { pārvaldes un } \\
\text { pašvaldību } \\
\text { mehānisma } \\
\text { raksturojums, } \\
\text { pašvaldību } \\
\text { finanšu datu } \\
\text { analīze, } \\
\text { pašvaldību } \\
\text { grupēšana. } \\
\text { 2. IA loma valsts } \\
\text { tiešajā pārvaldē, } \\
\text { IA pieejas } \\
\text { pašvaldībās, } \\
\text { trūkumu } \\
\text { identificēšana. }\end{array}$ & $\begin{array}{l}\text { Zinātniskā novitāte: } \\
\text { 1) pirmo reizi izveidots } \\
\text { modelis un piedāvāti } \\
\text { alternatīvie risinājumi } \\
\text { iekšējā audita ieviešanai } \\
\text { pašvaldībās; } \\
\text { 2) pirmo reizi sagatavota } \\
\text { pašvaldību iekšējā } \\
\text { audita vērtēšanas pieeja } \\
\text { un izstrādāts pašvaldību } \\
\text { iekšējā audita } \\
\text { pievienotās vērtības jeb } \\
\text { ieguvumu saraksts. } \\
\text { Praktiskā novitāte: } \\
\text { 1) analizējot Eiropas } \\
\text { valstu pieredzi, izvirzīti } \\
\text { priekšlikumi IA funkcijas } \\
\text { pilnveidošanai Latvijas } \\
\text { valsts tiešajā pārvaldē } \\
\text { un Latvijas pašvaldībās; } \\
\text { 2) sniegti ieteikumi } \\
\text { Latvijas pašvaldību } \\
\text { IA funkcijas vienotai } \\
\text { ieviešanai; } \\
\text { 3) pētījuma rezultātā } \\
\text { formulēti ieteikumi } \\
\text { izmainām Latvijas } \\
\text { Republikas lekšējā } \\
\text { audita likumā un likumā } \\
\text { "Par pašvaldībām”. }\end{array}$ & $\begin{array}{l}\text { 3.2.2. nodalıa } \\
\text { (3.9. attēls) } \\
\text { 3.2.2. nodal̦a } \\
\text { (3.4. un } \\
\text { 3.5. tabula) } \\
\text { 1.4.2. nodala }\end{array}$ \\
\hline
\end{tabular}

1.2. attēls. Autores kopējā pētījuma veikšanas posmu shēma

Avots: autores veidota shēma.

iekšējo auditoru aptauju, ekspertu aptauju, normatīvo aktu izpēti un finanšu datu analīzi, tiek analizēta valsts tiešās pārvaldes un pašvaldību IA sistēma. Pētījuma noslēgumā tiek izvirzīti priekšlikumi IA funkcijas pilnveidošanai. Nākamajā apakšnodaļā tiks veikta detalizēta IA definīcijas analīze, kas ir obligāts elements jebkuras sistēmas vērtēšanā. 


\section{3. lekšejjā audita definīcija, starptautiskie standarti un ètikas kodekss}

Sākotnēji audita (revīzijas) definīcijas ir radušās, neizdalot iekšējo auditu un ārējo auditu. Tālāk analizētas latviešu valodā pieejamās jēdzienu "audits" un "revīzija” definīcijas, kas pieejamas Latvijas Zinātņu akadēmijas Terminoloǵijas komisijas publikācijās. 2003. gadā V. Skujiṇa skaidro, ka termini "revīzija” un "revidents" latviešu valodā lietojami to tradicionālajā nozīmē, kas sniegta dažādās vārdnīcās: “audits” (latīṇu val. 'auditus' - "klausīšanās, dzirdēšana”) process, ko iniciē iestāde, uzṇēmums vai fiziskā persona, uzaicinot lietpratīgu speciālistu (auditoru), lai konstatētu iestādes, uzṇēmuma vai fiziskās personas saimnieciskās darbības stāvokli, iespējamos trūkumus u. tml. un saṇemtu ieteikumus stāvokḷa uzlabošanai; auditu veic, uzklausot nepieciešamo informāciju pēc stāstītā vai ievācot nepieciešamo informāciju pēc dokumentiem u. tml.; audita mērķis - nepiel̦aut iestādes, uzṇēmuma vai fiziskās personas bankrotu, saimnieciskās darbības lejupslīdi u. tml. un laikus novērst iespējamos traucējumus. Auditors - speciālists, kas īpaši sagatavots audita veikšanai. Terminu "revīzija”, "revidents” un "audits”, “auditors” nozīmes šḳīrumu sarežğì tas, ka angḷ valodā vārdi audit un auditor ${ }^{28}$ tiek lietoti abās nozīmēs.

2000. gada Ekonomikas skaidrojošā vārdnīca ${ }^{29}$ terminus "revīzija”, “audits" skaidro šādi: "Kādas iestādes, uzṇēmuma vai amatpersonas likumīga pārbaude, ko veic īpaša lietpratīga persona (revidents) un kas ietver informācijas apkopošanu par kādu uzṇēmējdarbību un šīs informācijas novērtēšanu, pārbaudot aprēķinu pareizību un pēc noteiktiem kritērijiem dodot savu revīzijas atzinumu. Ir šādas revīzijas: operāciju revīzija, atbilstības revīzija un gada pārskata revīzija."

Tacis - Dictionary of Economic and Management Terms, European Commission ${ }^{30}$ terminus "audits”, "revīzija” skaidro šādi: "Indivīda vai uzṇēmuma grāmatvedības dokumentu un uzskaites pārbaude saskaṇā ar profesionālajiem standartiem, lai noskaidrotu grāmatvedības uzskaites regularitāti un atbilstību, kā arī attiecīgi sagatavoto finanšu pārskatu ticamību."

2004. gada Ekonomikas terminoloǵijas apakškomisijā pieņemtie termini un definīcijas ${ }^{31}$ terminus "revīzija, audits, auditēšana" definē šādi: "Kādas juridiskās vai fiziskās personas darbības pārbaude, ko veic īpaša lietpratīga persona

\footnotetext{
${ }^{28}$ Skujiņa V. Vai termini audits un revīzija un arī auditors un revidents ir sinonīmi? Terminologijas Jaunumi. Pieejams: http://termini.lza.lv/article.php?id=70 [skatìts 23.02.2019.]

${ }^{29}$ Akadēmiskā terminu datubāze AkadTerm. Audita, revīzijas definīcijas. Pieejams: http://termini. lza.lv/term.php?term=rev\%C4\%ABzija\&list=rev\%C4\%ABzija\&lang=LV [skatîts 23.02.2019.]

${ }^{30}$ Turpat.

${ }^{31}$ Turpat.
} 
(revidents, auditors), apkopojot un novērtējot informāciju, sniedzot savu atzinumu un ieteikumus."

Trijās definīcijās no četrām uzsvars tiek likts uz saimnieciskās darbības, grāmatvedības un finanšu pārskata pārbaudēm. Dažādos IA attīstības posmos Iekšējo auditoru institūts publicējis iekšêjā audita definīciju ${ }^{32}$, kas IAI veidojusies vairākus gadu desmitus (1.3. tabula). Kopumā definīcijas IAI (ASV) ir publicētas trīs reizes. 2008. gada definīcija ${ }^{33}$ ir oficiāli tulkota latviešu valodā Tulkošanas un terminologijas centrā, to publicējis IAI Latvijā. Ši definīcija joprojām ir spēkā, un kopumā uz 2019. gada martu IAI mājaslapā (ASV) tā tulkota 40 valodās, tostarp arī latviešu valodā.

Pētot iekšèjā audita definīcijas literatūrā par ekonomiku (1.3. tabula), autore secina, ka IA definīcija pierāda: sākotnēji IA ir fokusēts uz grāmatvedības un finanšu darbību pārbaudi, taču jau 1947. gadā iekšējais auditors ir bijis padomdevējs, laika gaitā novērtēšanas lomu ir papildinājusi neatkarīga pārliecības radǐšanas funkcija, un mūsdienās iekšêjā audita būtiskā loma ir risku vadības, kontroles un pārvaldības procesu efektivitātes novērtēšana.

Analizējot iekšèjā audita definīcijas, pārliecỉbas radǐšanas pakalpojumi nozīmē, ka iekšējais auditors objektīvi vērtē pierādījumus, lai sniegtu neatkarīgu atzinumu vai secinājumus par procesu, sistēmu vai citu priekšmetu. Iekšējā audita darba procesus, audita darba uzdevumus un apjomu nosaka iekšējais auditors. Pārliecības radīšanas pakalpojumos parasti ir iesaistītas trīs puses:

1) persona vai grupa, kas tieši iesaistìta procesā, sistēmā vai citā audita priekšmetā, - procesa īpašnieks;

2) persona vai grupa, kas veic vērtējumu, - iekšējais auditors; un

3) persona vai grupa, kas izmanto vērtējumu, - lietotājs.

Konsultatīvie pakalpojumi pēc būtības ir padoma sniegšana, un parasti tos veic pēc darba uzdevuma klienta īpaša pieprasijuma. Konsultatīvā darba uzdevuma būtỉbu un apjomu nosaka, vienojoties ar darba uzdevuma klientu. Konsultatīvajos pakalpojumos parasti ir iesaistītas divas puses:

1) persona vai grupa, kas piedāvā padomu, - iekšējais auditors; un

2) persona vai grupa, kas lūdz padomu, - darba uzdevuma klients. Sniedzot konsultatīvos pakalpojumus, auditoram jāsaglabā objektivitāte un viņš nedrīkst uzṇemties vadỉbas pienākumus. ${ }^{34}$

${ }^{32}$ Iekšèjā audita definīcija (2008) Iekšējo auditoru institūts. Pieejams: http://iai.lv/lv/standarti [skatīts 23.02.2019.]

${ }_{33}$ Turpat.

${ }^{34}$ Iekšèjā auditoru institūta skaidrojumi IA definīcijai. Pieejams: http://iai.lv/ieksejam-auditoram/ iekseja-audita-definicija [skatìts 26.08.2015.] 


\section{3. tabula. lekšējā audita definīcijas attīstība lekšējo auditoru institūtā}

\begin{tabular}{|c|c|c|}
\hline Gads & Definīcija & $\begin{array}{c}\text { Autors, } \\
\text { avots }\end{array}$ \\
\hline 1947. & $\begin{array}{l}\text { IA ir neatkarīga novērtēšanas aktivitāte organizācijā grāmatvedības, } \\
\text { finanšu u. c. darbību pārbaudei, ir kā pamats aizsardzībai un } \\
\text { konstruktīvs pakalpojums vadībai. Tas ir kontroles veids, kas darbojas } \\
\text { novērtējot un mērot citu veidu kontroles. Tas attiecas galvenokārt } \\
\text { uz grāmatvedību un finanšu darbībām, bet var attiekties uz citiem } \\
\text { darbības veidiem. } \\
\text { IA ir padomdevēja, nevis izpildītāja funkcija. } \\
\text { lekšējais auditors nav galvenā persona organizācijā. }\end{array}$ & $\begin{array}{l}\text { Paziñojums par } \\
\text { iekšējā auditora } \\
\text { atbildību (Statement } \\
\text { of the Responsibilities } \\
\text { of the Internal } \\
\text { Auditor), IAI }\end{array}$ \\
\hline 1993. & $\begin{array}{l}\text { IA ir neatkarīga pārliecības radīšanas funkcija, kas izveidota } \\
\text { organizācijā, lai pārbaudītu un novērtētu tās darbības, tādējādi } \\
\text { sniedzot pakalpojumu organizācijai. }\end{array}$ & Definīcija, IAI \\
\hline 1999. & $\begin{array}{l}\text { IA ir neatkarīga, objektīva pārliecības radīšana un konsultēšana, lai } \\
\text { palielinātu organizācijas vērtību un pilnveidotu tās darbības. IA palīdz } \\
\text { organizācijai sasniegt tās mērksus, ieviešot sistemātisku, disciplinētu } \\
\text { pieeju, lai novērtētu un pilnveidotu riska vadības, kontroles un } \\
\text { pārvaldības procesu efektivitāti. }\end{array}$ & $\begin{array}{l}\text { Definīcija, IAI, } \\
\text { 2008. gadā } \\
\text { Latvijas IAI noteikts } \\
\text { oficiāls tulkojums }\end{array}$ \\
\hline
\end{tabular}

Avots: autores veidota tabula, pamatojoties uz Ramamoorti (2003), IAI (2008), Dābola (2013).

Latviešu valodā pieejamajā zinātniskajā un profesionālajā literatūrā joprojām tiek lietoti abi jēdzieni - "revidents" un "auditors", tāpat "revīzija” un “audits", definējot gan ārējo un iekšējo auditu, gan kopumā neizdalot audita veidu. Pētot jēdzienu "iekšèjais audits”, autore ir atradusi atšķirīgus skaidrojumus. Latviešu valodā, elektroniskajā angḷu-latviešu vārdnīcā letonika.lv tulkojot terminu “internal audit”, sastādītāji P. Krūmiņš un B. Znota lieto jēdzienu “iekšējā revīzija" 35 , arī Eiropas terminologijas elektroniskā vietnē (InterActive Terminology for Europe) atrodams tāds pats tulkojums. 1997. gada Ekonomikas terminu vārdnīcā uzṇēmējdarbībai darba grupa N. Grostiṇa un A. Pudula ${ }^{36}$ vadībā lieto jēdzienu "iekšējais revidents" (internal auditor) - uzṇēmuma darbinieks, kurš pārbauda uzṇēmuma iekšējās kontroles sistēmas. Literatūrā arī sastopams, pēc autores domām, nepilnīgs tulkojums, kad “internal audit” latviešu valodā tulko kā “iekšèjā finanšu pārbaude" 37 , kas ir daudz šaurāks jēdziens nekā IAI iekšèjā

${ }^{35}$ Internal audit termina tulkojums. Letonika. Angḷu-latviešu vārdnīca. Pieejams: http://www.letonika. lv/groups/default.aspx?cid=269404\&r=10331062\&lid=269404\&g=2\&q=internal\%20audit $\& h=4708$ [skatits 25.01.2017.]

${ }^{36}$ Ekonomisko terminu vārdnīca uzņèmējdarbībai. Latviešu-angḷu (1997) Rīga: Ekonomisko reformu institūts, AS "Preses nams", 111. lpp.

${ }^{37}$ Internal audit termina tulkojums. Letonika. Angḷu-latviešu vārdnīca. Pieejams: http://www.letonika. lv/groups $/$ default.aspx? cid $=269404 \& \mathrm{r}=10331062 \& \mathrm{lid}=269404 \& \mathrm{~g}=2 \& \mathrm{q}=$ internal\%20audit $\& \mathrm{~h}=4708$ [skatits 25.01.2017.] 
audita definīcijā. Tāpat Kembridžas vārdnīcā (Cambridge Dictionary) atrodams skaidrojums, ka iekšējais audits ir grāmatvežu vai vadītāju kontu vai darbību pārbaude. ${ }^{38}$

Grāmatvedības jēdzienu skaidrojošā vārdnīca ${ }^{39}$ (sast. V. Kvēle) ietver jēdzienu "iekšèjais revidents", ko skaidro kā "uzṇēmuma darbinieks vai SIA kapitāla īpašnieku izvēlēta persona, kura veic uzņēmuma iekšējo kontroli”, kam autore nepiekrīt. Tāpat pilnībā nevar piekrist G. Māldera iekšèjā audita definīcijai ${ }^{40}$, kas nosaka to, ka iekšējais audits būtībā ir iekšèjā kontrole, ko veic saskaņā ar doto uzdevumu un apstiprināto nolikumu.

Starptautiskā Grāmatvežu federācija (International Federation of Accountants - IFAC $)^{41}$ iekšèjā audita funkciju definē kā izveidotu struktūrvienību vai ārpakalpojumu. IA funkcijas ietver pārbaudes, izvērtēšanu, atbilstību un IKS uzraudzības efektivitāti. Iekšējie auditori ir profesionāḷi, kas veic darbības iekšējās revīzijas funkcijas nodrošināšanai.

Ekonomikas finanšu vārdnīcā iekšējais audits (internal audit) skaidrots kā uzņēmumā iedibināta novērtēšanas un uzraudzības funkcija uzskaites un iekšējo procedūru atbilstības pārbaudei. Iekšējais auditors (internal auditor) uzṇēmuma darbinieks, kas pilda iekšējā audita funkcijas ${ }^{42}$.

Jēdzieni "auditors" un "revidents" tiek lietoti kopā, attiecinot uz tiem angḷu terminu "auditor". Tāpat minētajā vārdnīcā sadal̦as "Angḷu-latviešu terminu vārdnīca" terminam "audit" latviešu valodā atbilst jēdzieni "audits", "revīzija", savukārt jēdzieni "internal audit" un "internal auditor" attiecīgi tiek tulkoti kā "iekšējais audits" un "iekšējais auditors".

Iekšèjā audita ieviešanas nepieciešamību valsts pārvaldē nosaka ES izvirzìtās prasības attiecībā uz administratīvās spējas paaugstināšanu, kā arī Latvijas valsts pārvaldes iekšējā nepieciešamība. Iekšējo auditu parasti uzskata par pakalpojumu vadībai, lai tā efektīvi varētu pieņemt lēmumus par uzṇēmuma finansiāli saimniecisko darbỉbu.

V. Rouldigins Starptautiskajā biznesa skaidrojošā vārdnīcā ir iekḷāvis šādu skaidrojumu par iekšējiem auditoriem: "Viņiem jāpārbauda, vai organizācijā pieņemtā datu vākšanas un aktīvu aizsardzības kārtība atbilst oficiālajiem

\footnotetext{
38 “internal audit” termina tulkojums. Letonika. Angḷu-latviešu vārdnīca. Pieejams: http://www.letonika. lv/groups/default.aspx?cid=269404\&r=10331062\&lid=269404\&g=2\&q=internal\%20audit \&h=4708 [skatīts 25.01.2017.]

${ }^{39}$ Kvēle V. (2005) Grāmatvedības jēdzienu skaidrojošā vārdnīca. Rīga: Avots, 253. lpp.

${ }^{40}$ Mālderis G. (2001) Revīzija un audits. Rīga: SIA “Biznesa augstskola Turība”, 92. lpp.

${ }^{41}$ Internal audit definition. Glossary IFAC. Available at: http://www.ifac.org/system/files/downloads/ a005-2010-iaasb-handbook-handbook-glossary.pdf [cited 24.01.2017.]

42 Ekonomikas un finanšu vārdnīca (2003) Rīga: Norden AB, 58.-59. lpp.
} 
1.4. tabula. lekšējā audita definīcijas attīstība Latvijas Republikas normatīvajos aktos (1999-2012)

\begin{tabular}{|c|c|c|c|}
\hline 1999. gads & 2002. gads & 2010. gads & 2012. gads \\
\hline $\begin{array}{c}\text { MK noteikumi Nr. } 342 \\
\text { "Noteikumi par iekšējo } \\
\text { auditu” }\end{array}$ & \multicolumn{3}{|c|}{ lekšējā audita likums } \\
\hline $\begin{array}{l}\text { lekšējais audits ir iestādes } \\
\text { IKS novērtēšana, kas } \\
\text { sniedz ieteikumus } \\
\text { tās uzlabošanai, lai } \\
\text { nodrošinātu efektīvu } \\
\text { valsts pārvaldes darbīibu. }\end{array}$ & $\begin{array}{l}\text { lekšējais audits - neatkarīga } \\
\text { un objektīva darbība, kuru } \\
\text { veic iekšējais auditors un } \\
\text { kuras mērksis ir pilnveidot } \\
\text { ministrijas vai iestādes } \\
\text { darbību, sistemātiski } \\
\text { pārbaudot un novērtējot } \\
\text { ministrijas vai iestādes IKS } \\
\text { kvalitāti un efektivitāti un } \\
\text { sniedzot ieteikumus šīs } \\
\text { sistēmas pilnveidošanai. }\end{array}$ & $\begin{array}{l}\text { lekšējais audits - } \\
\text { iekšējā auditora } \\
\text { neatkarīga, objektīva } \\
\text { darbība, kuras } \\
\text { rezultātā tiek sniegts } \\
\text { auditora atzinums } \\
\text { vai konsultācija ar } \\
\text { mērki pilnveidot IKS } \\
\text { darbību ministrijā un } \\
\text { iestādē. }\end{array}$ & $\begin{array}{l}\text { lekšējais audits - } \\
\text { iekšējā auditora } \\
\text { neatkarīga un } \\
\text { objektīva darbība, } \\
\text { kuras rezultātā tiek } \\
\text { sniegts IKS darbības } \\
\text { novērtējums, lai } \\
\text { pilnveidotu IKS } \\
\text { darbību ministrijā } \\
\text { un iestādē. }\end{array}$ \\
\hline
\end{tabular}

Avots: autores veidota tabula, pamatojoties uz Latvijas Republikas normatīvajiem aktiem.

priekšrakstiem. Darba gaitā iekšējais auditors lieto daudzas neatkarīgo auditoru metodes, savukārt neatkarīgie auditori nereti balstās uz iekšējo auditoru veikto darbu." ${ }^{43}$

Latvijas normatīvajos aktos valsts pārvaldes IA definīcija ir veidojusies pakāpeniski, sākot no 1999. gada, kad IA sistēmas ieviešana tika uzsākta. Galvenais un kopīgais IA definīcijām, pēc autores domām, ir mērḳis, proti, sekmēt IKS uzlabošanu, un uzdevums - sniegt profesionālu atbalstu un pakalpojumu iestādes (sabiedrības) vadībai, novērtējot izveidoto IKS, kas ietver trīs galvenās jomas:

1) darbību efektivitāte un produktivitāte;

2) finanšu pārskatu ticamība;

3) atbilstība normatīvajiem aktiem.

Analizējot visas četras Latvijas valsts pārvaldes IA definīcijas (1.4. tabula), var secināt, ka jau ar pirmo definīciju ir akcentēta IKS novērtēšana, lai nodrošinātu IKS pilnveidošanu. Pirmā definīcija (1999) aptver visu valsts pārvaldi, taču, sākot ar 2002. gadu, sistēma tiek sašaurināta, ietverot iekšêjā audita pārziṇā tikai ministrijas un iestādes. Gan 2010. gada, gan 2012. gada definīcijas redakcionāli ir l̦oti līdzīgas, uzsverot, ka IA ir iekšèjā auditora darbība, sniedzot IKS novērtējumu. 2010. gada definīcijā norādīts, ka iekšējais auditors var sniegt atzinumu vai konsultāciju, savukārt 2012. gada Iekšêjā audita likumā redakcijas

\footnotetext{
${ }^{43}$ Rouldigins V. (2005) Starptautiskā biznesa skaidrojošā vārdnīca. Rīga: Jumava, 36. lpp.
} 
pēdējā definīcija ir atgriešanās pie sākotnējās versijas, kur IA galvenā būtība ir IKS novērtējums.

Tā kā Latvijas Zinātṇu akadēmijas akadēmiskajā terminu datubāzē AkadTerm iekšējā audita definīija nav ietverta, autore iesaka iekḷaut termina "iekšèjais audits" skaidrojumu akadēmiskajā terminu datubāzē, priekšlikumā ietverot Iekšèjā auditoru institūta definīciju, kas, autoresprāt, vispilnīgāk raksturo iekšejo auditu:

"Iekšêjais audits ir neatkarīga, objektīva pārliecības radǐšana un konsultēšana, lai palielinātu organizācijas vērtību un pilnveidotu tās darbības. Iekšējais audits palīdz organizācijai sasniegt tās mērḳus, ieviešot sistemātisku, disciplinētu pieeju, lai novērtētu un pilnveidotu riska vadības, kontroles un pārvaldības procesu efektivitāti." ${ }^{34}$

Autore savu ieteikumu (ar standartu un Iekšèjā audita likuma definīcijām) ir nosūtijusi elektroniski Latvijas Zinātņu akadēmijas Terminoloǵijas komisijai un saņēmusi izrakstu no sēdes protokola, ka Latvijas zinātniekiem ir atšķirīga un noraidoša attieksme pret jauna termina iekḷaušanu AkadTerm datubāzē. R. Karnite pauž viedokli, ka pret to ir pretenzijas Ekonomikas terminologijas apakškomisijai, jo "tā ir "revizzija", nevis "audits"; "audits" ir radies no angḷu valodas, bet "revīzija" ir no vācu valodas". A. Lauznis savukārt pauž savu viedokli un uzskata, ka "audits ir iekšējais, revīzija - ārējais". J. Baldunčika viedoklis ir tāds, ka "Trimdas latviešu asociācija ir izdevusi tehnikas apskatu, un tās iekšējos pārskatos ir termins "revidenta ziņojums", kam pretī - auditor's report. Pat viṇi tādu "auditu" nelieto". Komisija nolēma turpmāku ši jautājuma izskatǐšanu atlikt. ${ }^{45}$

Autore kopumā secina, ka latviešu valodā termini "iekšêjais audits" un "iekšêjā revīzija" ir lietojami un uzskatāmi par sinonīmiem, jo no angḷu valodas latviešu valodā šo jēdzienu varam tulkot divējādi.

Vienota viedokḷa nav arī Latvijas zinātnieku vidū. Ekonomikas skaidrojošā vārdnīcā autori terminus "audits" un "auditors" skaidro ar jēdzieniem "revīzija" un "revidents". Revīzija ir kādas iestādes, uzņēmuma vai amatpersonas likumīga pārbaude, ko veic īpaša lietpratīga persona (revidents) un kas ietver informācijas apkopošanu par kādu uzṇēmējdarbību un šīs informācijas novērtēšanu, pārbaudot aprēḳinu pareizību un pēc noteiktiem kritērijiem dodot savu revīzijas

\footnotetext{
${ }^{44}$ Iekšējā audita definīcija. Iekšējo auditoru institūts, 2008. Pieejams: http://iai.lv/lv/standarti [skatìts 20.01.2012.]

${ }^{45}$ Izraksts no LZA TK 13.09.2016. sēdes protokola Nr. 6/1130.
} 
atzinumu ${ }^{46}$ Autori izdala operāciju revīziju, atbilstības revīiju, kas atbilst arī IA veidiem, un gada pārskatu revīziju.

IA profesionālās prakses starptautiskie standarti (turpmāk - Standarti) ${ }^{47}$ pieņemti IAI ASV 1978. gadā un bez izmaiņām spēkā ir bijuši vairāk nekā 20 gadus. Standarti ir pārskatīti 2002. un 2006. gadā ar oficiāliem tulkojumiem 32 valodās. Izmaiņas Standartos atbilstoši IAI publikācijām bijušas 2007., 2009. 2011., 2012. un 2017. gadā. Standarti balstās uz IA definīciju, kas noteic, ka, veiksmīgi ieviešot IA, organizācija sasniedz mērķus un tās vērtība palielinās.

Standarti ietver divas galvenās kategorijas: organizatoriskos standartus un darba izpildes standartus. Organizatoriskie standarti raksturo organizācijas un indivīdus, kuri veic IA. Darba izpildes standartos ir izklāstīta IA darbību būtība un noteikti kvalitātes kritēriji, attiecībā pret kuriem var novērtēt šo pakalpojumu izpildi. Organizatoriskie un darba izpildes standarti attiecas uz visiem IA pakalpojumiem. Ieviešanas standarti papildina organizatoriskos un darba izpildes standartus, nosakot prasības, kas attiecas uz pārliecības sniegšanas vai konsultatīvajiem pakalpojumiem. ${ }^{48}$

Iekšèjo auditoru institūts 2007. gadā pieņēma un izsludināja starptautisko profesionālās prakses ietvaru, kas ir pamats IA profesijai un profesionālās prakses attīstībai. Tas ir rūpīgas izpētes, konsultāciju un IA galveno principu apspriešanas rezultāts. SPPI ietver IA definīciju (1.3. attēls), Ėtikas kodeksu, IAI izdotos Standartus, kā arī oficiālās nostājas, prakses vadlīnijas un prakses ceḷvežus.

Ietvars sastāv no divām vadlīniju kategorijām: ieteicamām un obligātām.

Kopš 2015. gada ir izmaiṇas SPPI, kas paredzētas, lai atvieglotu auditoru darbu arvien sarežğìtākajā izaicinājumiem pilnajā vidē, vairotu un aizsargātu organizācijas vērtību, nodrošinot uz riskiem balstītu un objektīvu pārliecību, konsultācijas un izpratnes spēju. ${ }^{49}$ Izmaiṇas sāktas ar IA misijas apstiprināšanu. IA misija ir organizācijas vērtību palielināšana un aizsardzība, lai nodrošinātu objektīvu un uz riskiem balstītu pārliecību, sniedzot padomus, kā arī veicinot izpratni. ${ }^{50}$ Jaunā SPPI mērḳis ir nodrošināt IA speciālistus ar visu, kas tiem

\footnotetext{
${ }^{46}$ Ekonomikas skaidrojošā vārdnīca (2000) Sastādījis autoru kolektīvs R. Grēviņas vadībā. Rīga: Zinātne, 702. lpp.

${ }^{47}$ Iekšèjā audita profesionālās prakses starptautiskie standarti (standarti). IAI. Pieejams: https://global. theiia.org/translations/PublicDocuments/IPPF-Standards-2017-Latvian.pdf [skatits 30.06.2017.]

${ }^{48}$ Turpat.

${ }^{49}$ Dābola V. Izmainas standartos. Pieejams: http://iai.lv/izmainas-standartos-jauna-struktura-jaunamlaikmetam/ [skatìts 30.06.2017.]

${ }^{50}$ Iekšējā audita profesionālās prakses starptautiskie standarti (standarti). IAI. Pieejams: https://global. theiia.org/translations/PublicDocuments/IPPF-Standards-2017-Latvian.pdf [skatìts 30.06.2017.]
} 


\begin{tabular}{|c|c|c|c|c|c|}
\hline \multirow{5}{*}{ 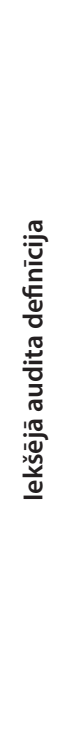 } & \multicolumn{3}{|c|}{ Ētikas kodekss } & \multirow{5}{*}{ 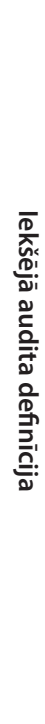 } & \multirow[b]{2}{*}{ leteicams } \\
\hline & 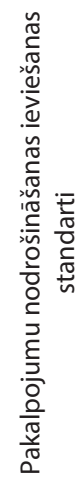 & $\begin{array}{l}\text { Organizatoriskie standarti: } \\
\text { - Mērkis, pilnvarojums un atbildība } \\
\text { - Neatkarība un objektivitāte } \\
\text { - Prasme un pienācīga profesionālā rūpība } \\
\text { - Kvalitātes nodrošināšanas un uzlabošanas sistēma } \\
\\
\text { Darba izpildes standarti: } \\
\text { - IAS vadīšana } \\
\text { - Darba būtība } \\
\text { - Darba uzdevuma plānošana } \\
\text { - Darba uzdevuma izpilde } \\
\text { - Rezultātu paziňošana } \\
\text { - Darba gaitas pārraudzība } \\
\text { - Rezolūcija par augstākās vadības akceptēto risku }\end{array}$ & 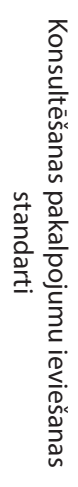 & & \\
\hline & \multicolumn{3}{|c|}{ Oficiālās nostājas } & & \multirow{3}{*}{ Obligāts } \\
\hline & \multicolumn{3}{|c|}{ Prakses vadlīnijas } & & \\
\hline & \multicolumn{3}{|c|}{ Prakses celveži } & & \\
\hline
\end{tabular}

1.3. attēls. Starptautiskas profesionālās prakses ietvars (SPPI)

Avots: autores veidota shēma, pamatojoties uz IPPF (2009).

nepieciešams, lai "uzlabotu un aizsargātu organizatorisko vērtību" arvien mainīgajā biznesa vidēes1.

Jaunais SPPI (1.4. attēls) joprojām sastāv no divām dalāām: Strongly Recommended Guidance, kas tagad pārdēvēti kā "Ieteicamie norādījumi", ar sadaḷām, kas ietver IA definīciju, Standartus un Ētikas kodeksu. Papildus iekḷauta IA misija (Mission) un 10 pamatprincipi (Core Principles), kas ietver šādus uzdevumus: darboties vienoti; uzskatāmi izrādīt kompetenci un pienācīgu profesionālo rūpību; būt objektīvam un brīvam no ietekmes (neatkarīgam); darboties saskaṇā ar organizācijas stratēégijām, mērḳiem un riskiem; būt pienācīgi pozicionētam un nodrošinātam ar atbilstošiem resursiem; nodrošināt darba kvalitāti un nepārtraukti pilnveidoties; būt efektīvam sazin̄ā; nodrošināt uz riskiem balstītu pārliecỉbu; būt vērīgam, tālredzịgam un uz nākotni orientētam; sekmēt organizācijas darbības pilnveidošanos. Pamatprincipu izstrādātāji uzskata, ka ar principiem tiek nodrošināts pamats SPPI un Standartiem, kas nosaka IA profesiju. Principi uzsver IA lomu kā dinamisku instrumentu, kas ir neatṇemama iestādes sastāvdaḷa.

${ }^{51}$ Dābola V. (2016) Izmaiṇas standartos. Jauna struktūra jaunam laikmetam. IAI Vēstnesis, Nr. 9, 5. lpp. 


\begin{tabular}{|c|c|c|}
\hline $\begin{array}{l}\text { 2007.-2014. gada } \\
\text { SPPI versija }\end{array}$ & & $\begin{array}{l}\text { No } 2015 . \text { gada spēkā } \\
\text { esošā SPPI versija }\end{array}$ \\
\hline Norādijjumi & & $\downarrow$ IA misija \\
\hline $\begin{array}{l}\text { Obligātie norādījumi: } \\
\text { definīcija, starptautiskie standarti, Ētikas kodekss }\end{array}$ & $\begin{array}{l}\text { Oblig } \\
\text { pama } \\
\text { Étikas }\end{array}$ & $\begin{array}{l}\text { orādijumi: } \\
\text { ipi, definīcija, starptautiskie standarti, } \\
\text { sss }\end{array}$ \\
\hline $\begin{array}{l}\text { Stingri ieteicamie norādījumi: } \\
\text { Viedokḷa dokumenti (Position Papers) } \\
\text { Prakses vadlīnijas (Practice Advisories) } \\
\text { Prakses rokasgrāmatas (Practice Guides) }\end{array}$ & $\begin{array}{l}\text { leteic } \\
\text { levieš } \\
\text { Papild }\end{array}$ & $\begin{array}{l}\text { norādijumi: } \\
\text { orādījumi (Implementation Guidance) } \\
\text { àdījumi (Supplemental Guidance) }\end{array}$ \\
\hline
\end{tabular}

\section{4. attēls. Starptautiskais profesionālās prakses ietvars 2007.-2014. gadā un jaunā versija no 2015. gada}

Avots: autores veidota shēma, pamatojoties uz IPPF (2015).

Bijušās Prakses vadlīnijas (The Practice Advisories) ir aizstātas ar Ieviešanas norādijumiem (Implementation Guidance). IAI pārstāve Jenitha John norāda uz šo maiṇu kā "skatu uz nākotnes materiāliem, lai nodrošinātu vienotu un konsekventu IA praksi visā pasaulē”. Savukārt Papildu norādījumi (Supplemented Guidance) ir aizstājuši Practice Guides, bet "Viedokḷu dokumenti" (Position Papers) tiks izdoti, taču tie vairs nebūs SPPI sastāvā.

Iekšějo auditoru Ëtikas kodeksa ${ }^{-52}$ noteiktie principi un profesionālās ētikas normu (godīgums, objektivitāte, konfidencialitāte un kompetence) ievērošana, pēc autores domām, ir viens no sarežg̀itākajiem posmiem iekšējā auditora darbā. 2013. gadā IAI publicējis Globālo IA kompetences ietvaru (The IIA Global Internal Audit Competency Framework), kas ietver 10 pamatkompetences:

1) profesionālā ètika: veicina un piemēro profesionālo ētiku;

2) IA vadīšana: izveido un vada IA funkciju;

3) Starptautiskā profesionālās prakses ietvara piemērošana;

4) pārvaldība, risks un kontrole: piemēro caur pārvaldības, risku un kontroles izpratni organizācijā;

5) biznesa vērīgums: saglabā zināšanas par biznesa vidi, nozares un organizācijas specifiskajiem faktoriem;

6) komunikācija: ietekmīgs process;

7) pārliecība un sadarbība: pārliecina un motivē citus caur sadarbību;

8) kritiskā domāšana: piemēro procesu analīzē, problēmu risināšanas tehnikas;

\footnotetext{
${ }^{52}$ Ētikas kodekss. Pieejams: https://na.theiia.org/standards-guidance/mandatory-guidance/Pages/Codeof-Ethics.aspx [skatits 26.01.2018.]
} 
9) IA veikšana: IA saistïbu izpilde;

10) uzlabojumi un inovācijas: ietver izmaiņas, veicina uzlabojumus un inovācijas. ${ }^{53}$

IA misija un pamatprincipi, kā arī Standarti un Ētikas kodekss oficiāli iztulkoti un publicēti globālajā IAI mājaslapā 40 valodās, tostarp arī latviešu valodā.

Autore uzskata, ka IA jābūt veiktam saskaņā ar labākās prakses prasībām, valsts pārvaldē saskaņā ar normatīvo aktu prasībām, kā arī atbilstoši Standartiem un ētikas normām. Lai sekmīgi pildītu visas minētās normas, ir nepieciešama atbilstoša profesionālā pieredze un apmācība. Iekšējam auditoram ir jāsniedz vērtējums par organizācijas vai iestādes IKS efektivitāti un ieteikumi IKS uzlabošanai, tāpēc ḷoti būtiski ir izprast iekšèjās kontroles pamatprincipus.

Tāāāk autore pievēršas detalizētai IA attīstībai publiskajā sektorā, ietverot analīzi par Eiropas valstīm un Latviju.

\section{4. lekšējā audita attīstība publiskajā sektorā mūsdienās}

\subsection{1. lekšējā audita funkcija un tās nozìme}

Iekšējais audits arvien ir viens no visaptverošākajiem organizāciju pārvaldības un vadības instrumentiem, kur pats IA ir globāla pašregulējoša profesija. Tà pamatota uz ètiku, standartiem, sertificēšanu un profesionālo attīstību. ${ }^{54}$

IA attīstîba kopumā pasaulē gadu gaitā ir attīstījusies un pilnībā atbilst 1.5. attēlā ietvertajiem iekšējo auditoru izaicinājumiem, ko apkopojis IAI pētījumu fonds.

Pasaules ekonomiskās attīstības ietekmē mainījušās arī IA pieejas - iekšējie auditori izstrādā jaunas stratēgijas un spēj nodrošināt pakalpojumus, mainot tradicionālo IA modeli (1.5. attēls). IA izmaiṇas gadu gaitā ir ietekmējuši vairāki nozīmīgi faktori:

- IA daudzpusības atzīšana;

- pagātnes skatijuma pārtapšana nākotnes redzējumā;

- iekšèjā audita kā padomdevēja lomas uzsvēršana;

- pieaugoša loma risku novērtēšanas jomā. ${ }^{55}$

${ }^{53}$ Internal Audit Competency Framework. Available at: https://global.theiia.org/about/about-internalauditing/Pages/Competency-Framework.aspx [cited 29.06.2017.]

${ }^{54}$ Strazdiņš P. (2008) Pieci izaicinoši aspekti iekšèjā audita profesijā. Bilance, Nr. 13 (193), 6-8. lpp.

${ }^{55}$ Independence and Objectivity: A Framework for Internal Auditors. The Institute of Internal Auditors: Altamonte Springs, FL, 2001, p. 61. 


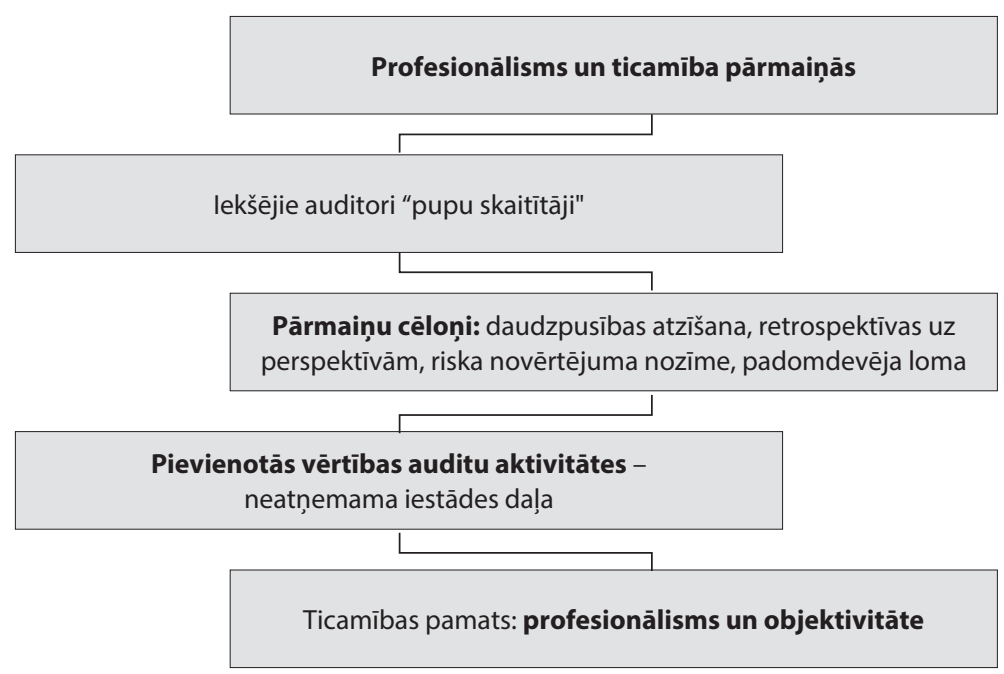

\section{5. attēls. lekšējo auditoru izaicinājumi mūsdienās}

Avots: autores veidota shēma, pamatojoties uz IIA (2001)

IA ir jānodrošina pārliecība un padomdevēja loma: rūpīgi jāpārdomā tas apjoms, kurā audits varētu nodrošināt palīdzību; kur ir vajadzība, audita darbam ir jābeidzas ar rekomendācijām, bet vadības pienākums ir pien̦emt vai noraidīt auditora viedokli. Ja padoms tiek pieņemts, auditors nedrīkst būt atbildīgs par jauno procedūru plānošanu vai ieviešanu, bet auditori ir izmaiņu katalizatori. Nepārkāpjot robežu, auditoram jānorāda, kā izmaiņas sasniedzamas. ${ }^{56}$

Jau 1950. gadā IAI pētīja dažādu nozaru IA īpatnības. Laika gaitā līdz mūsdienām attīstījušies vairāki IA sektori, kas ir savā ziṇā atškirīgi:

1) valsts pārvaldes IA;

2) finanšu sektora IA;

3) privātā sektora IA.

Lai gan regulējums normatīvajos aktos publiskajā sektorā dažādās valstīs ir atšķirīgs, pat vienā valstī ir atšķirīgas pieejas valsts tiešajā pārvaldē, pašvaldībās un valsts kapitālsabiedrībās, arī finanšu jeb banku sektorā ir atšķirīgi regulējumi, kas nosaka struktūru, funkcijas, delegéjumu un atbildību, taču kopumā vispārējie IA uzdevumi ir kopīgi:

1) pārbaužu veikšana saskaņā ar apstiprināto plānu;

2) darbības atbilstību uzraudzī̌sana, ņemot vērā normatīvos aktus un vadības lēmumus;

\footnotetext{
${ }^{56}$ Wade K. W. (2001) Iekšejāā audita apjoms. Grāmatvedība un revizija. 2001/5, 11.-13. lpp.
} 
3) IKS efektivitātes neatkarīga novērtējuma un ieteikumu sniegšana tās uzlabošanai;

4) risku un to kvalitatīvo un kvantitatīvo rādìtāju noteikšana un novērtēšana;

5) ziņojumu sagatavošana par veiktajām pārbaudēm - konstatētajiem trūkumiem, pārkāpumiem, nepietiekami kontrolētiem riskiem utt.;

6) ieteikumu izstrādāšana vadībai atklāto problēmu risināšanai;

7) vadības informēšana par gadījumiem, kad atklātie trūkumi nav novērsti.

IA parasti uzskata par pakalpojumu vadībai, lai tā efektīvi varētu pieņemt lēmumus attiecībā uz uzņēmuma finansiāli saimniecisko darbību. Tā kā IA var būt uzṇēmuma struktūrvienība, tās rīcībā parasti ir vairāk informācijas nekā ārējam auditam, kas uzṇēmumu pārbauda tikai epizodiski. ${ }^{57}$

IA procesi, kas veidoti atbilstoši IA praksei (1.6. attēls) saskaņā ar starptautisko profesionālās prakses ietvaru, ko izsludinājis IAI, uzskatāmi parāda trīs secīgus IA procesus ierakstu līmenī, procesu līmenī un ziṇošanas lìmenī.

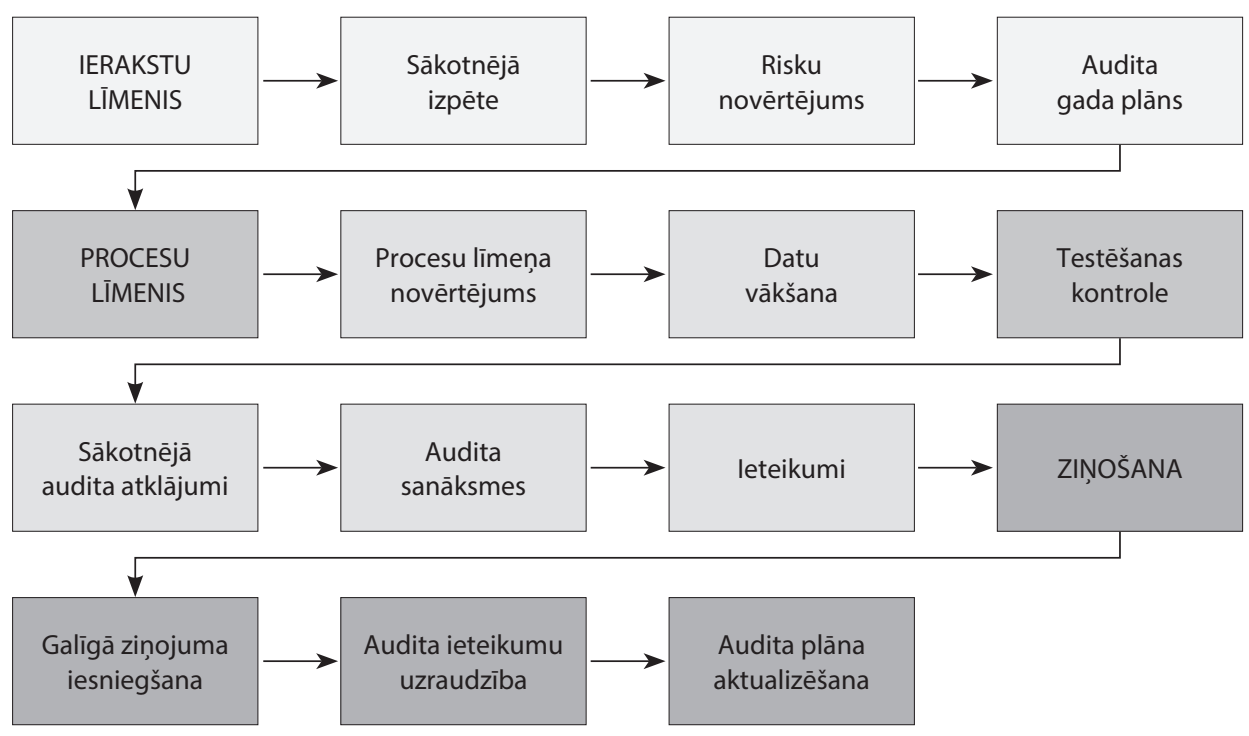

\section{6. attēls. lekšējā audita procesi atbilstoši Standartiem}

Avots: autores veidota shēma, pamatojoties uz Astrals Internal Audit Methodology (2012).

\footnotetext{
${ }^{57}$ Mālderis G. (2008) Grāmatvedība. Revīzija. Audits. Rīga: SIA “Biznesa augstskola Turība”, 48. lpp.
} 
Analizējot IA pieejas un metodiku pasaules valstīs, būtiski ir minēt IAI Pētijumu fonda (IAIPF) veiktos CBOK starptautiskos pētijumus par globālo iekšèjā audita praksi pasaulē ar ievērojamu skaitu respondentu no dažādām pasaules valstīm: 2006. gadā aptaujā piedalijāa 9366 respondenti, 2010. gada aptaujā piedalījās 13582 praktizējoši iekšējie auditori, IA pakalpojumu sniedzēji, augstskolu mācībspēki no 107 pasaules valstīm, savukārt 2015. gadā 14518 respondenti no 166 valstim.

Pētijumos ietverti vairāki ziṇojumi, salīdzinot 2006., 2010. un 2015. gada aptauju datus par galvenajām IA darbībām un iezīmējot profesijas nākotnes trajektoriju. Apkopotie aptaujas rezultāti (1.5. tabula) liecina, ka iekšējie auditori-praktikiki 2010. gadā identificē četras galvenās pieejas, gatavojot iekšējā audita plānus: uz riska pamatota metodoloǵija, iestādes vadỉbas prasības, iepriekšèjo gadu auditu plāni un konsultēšanās ar nodalıu vadītājiem vai iestādes vadību.

Uz riska novērtējumu balstītu audita pieeju jeb IA plāna izstrādi, kas tiek gatavota, pamatojoties uz riska novērtējumu, jau 2010. gadā izmantoja 21,9\% no IAIPF pētijumā aptaujātajiem pasaules iekšèjiem auditoriem.

IA gada plāniem jābūt vērstiem uz nozīmīgiem iestādes riskiem, tāpat tiem jāatbilst kopējai iestādes stratēǵijai. Pasaules auditoru aptauja 2015. gadā parādīja, ka iekšējie auditori vairāk izmanto vadības prasības, konsultēšanos ar nodaḷu vadītājiem un iestādes vadību, tāpat arī Audita komitejas prasības jeb konsultējas ar Audita komiteju (1.5. tabula). Lai gan pētāmo gadu aptauju jautājumu piedāvātās atbildes pa gadiem ir bijušas atšḳirīgas, abos pētījumos vadības prasības ir nozīmīgas IA gada plānu sagatavošanā.

\section{5. tabula. lekšējo auditoru izmantotās pieejas, gatavojot iekšējā audita plānu}

\begin{tabular}{|l|c|c|}
\hline \multicolumn{1}{|c|}{ Pieeja } & $\begin{array}{c}\text { Aptaujātie (\%), kas } \\
\text { izmanto attiecīgo } \\
\text { pieeju (2010. gada } \\
\text { aptauja*) }\end{array}$ & $\begin{array}{c}\text { Aptaujātie (\%), kas } \\
\text { izmanto attiecīgo } \\
\text { pieeju (2015. gada } \\
\text { aptauja*) }\end{array}$ \\
\hline Uz riska pamatotas metodoloǵijas izmantošana & $21,9 \%$ & - \\
\hline Vadības prasības & $18,10 \%$ & $75 \%$ \\
\hline Izmantoti iepriekšējo gadu auditu plāni & $15,3 \%$ & - \\
\hline Konsultēšanās ar nodal̦u vadītājiem vai iestādes vadību & $14,20 \%$ & $62 \%$ \\
\hline Atbilstības / noteiktās prasības & $13,90 \%$ & - \\
\hline Audita komitejas prasības & $12,60 \%$ & $56 \%$ \\
\hline Ārējo revidentu prāības vai konsultēšanās ar ārējo revidentu & $8,20 \%$ & - \\
\hline
\end{tabular}

Avots: autores veidota tabula, pamatojoties uz IAIPF (2010) un Ivanova (2015).

*Aptauju jautājumu iespējamās atbildes pa gadiem bija atškirīgas. 
1.6. tabula. lekšējā audita darbības no kopējām IAS darbībām 2010. gadā pasaulē

\begin{tabular}{|c|c|}
\hline lekšējā audita darbība & $\begin{array}{l}\text { \%* no kopējā } \\
\text { IA darba }\end{array}$ \\
\hline Funkciju auditi & 88,9 \\
\hline Atbilstības auditi & 75,1 \\
\hline Finanšu risku auditi & 71,6 \\
\hline Izmeklēšanas, krāpšanās un neatbilstības auditi & 71,2 \\
\hline lekšējās kontroles sistēmas efektivitātes novērtēšanas (COSO u. c.) auditi & 68,8 \\
\hline IT risku auditi & 61,7 \\
\hline Informācijas risku auditi & 61,4 \\
\hline Organizācijas risku vadības procesu auditi & 56,6 \\
\hline Projektu vadības nodrošināšanas, galveno projektu auditi & 55,4 \\
\hline Drošības novērtējuma un izmeklēšanas auditi & 52,8 \\
\hline Palīdzỉba ārējam auditam & 52,0 \\
\hline Vadības auditi & 49,9 \\
\hline Korporatīvās vadības pārbaudes & 44,5 \\
\hline Katastrofu seku pārbaude un atbalsts & 40,5 \\
\hline $\begin{array}{l}\text { Risku, kontroles, atbilstības apmācības un organizācijas personāla izglītošanās } \\
\text { sekmēšanas auditi }\end{array}$ & 40,0 \\
\hline Ārpakalpojumu funkciju auditi & 35 \\
\hline Ētikas auditi & 32,1 \\
\hline Biznesa dzīvotspējas novērtējums & 26,6 \\
\hline Organizācijas stratēǵijas pārbaudes izpildes pārbaudes & 25,3 \\
\hline Due diligence pārbaudes korporatīvie pirkumi, apvienošanās u. c. & 24,8 \\
\hline Kvalitātes / ISO auditi & 24,0 \\
\hline Sociālie un ilgtspējas auditi (korporatīvi sociālā atbildība, vide) & 19,6 \\
\hline Atbilstība Starptautiskajiem finanšu pārskatu standartiem IFRS & 19,4 \\
\hline Izpildvaras atlīdzības novērtējums & 18,5 \\
\hline Paplašinātas biznesa ziṇošanas valodas ieviešana & 5,3 \\
\hline
\end{tabular}

Avots: autores veidota tabula, pamatojoties uz IAIPF (2010).

* Respondenti varēja izvēlēties vairākas atbildes, tāpēc kopā tās neveido 100\%.

Standarts 2000 "IA struktūrvienības vadīšana" nosaka to, ka IA vadītājam ir efektīvi jāvada IAS, lai nodrošinātu, ka tā palielina organizācijas vērtību. IA tiek efektīvi vadìts, ja IAS darbs nodrošina nolikumā noteikto mērķu sasniegšanu un pienākumu izpildi, tāpat IAS atbilst IA definīcijai un Standartiem, kā arī IA struktūrvienības darbinieki ievēro Ētikas kodeksu un Standartus ${ }^{58}$.

Standartos tāpat noteikts, ka IA vadītājs ir atbildīgs par IA funkcijas izveidi, par novērtējumu un efektivitātes uzlabošanu pārvaldības, risku vadības un kontroles procesos.

${ }^{58}$ Iekšejā audita profesionāāās prakses starptautiskie standarti (Standarti). IAI. Pieejams: https://global. theiia.org/translations/PublicDocuments/IPPF-Standards-2017-Latvian.pdf [skatits 30.06.2017.] 
Pamatojoties uz IAIPF pētījumiem, pasaulē vecākās IAS pastāv vairāk nekā 50 gadus un iekšèjie auditori veic dažādus IA. Visvairāk aptaujā atzīmētie bija funkciju auditi, atbilstības auditi, finanšu risku auditi, izmeklēšanas, krāpšanās un neatbilstības auditi. 50-70\% no iekšèjā audita darbībām respondenti patērē iekšejās kontroles sistēmas efektivitātes novērtēšanai (COSO u. c.), IT risku auditiem, informācijas risku, projektu vadības nodrošināšanai, drošībai un palīdzībai ārējiem auditiem. Iekšējie auditori vismazāk pēc aptaujas datiem 2010. gadā veica biznesa valodas ieviešanas auditus, izpildvaras atlīdzības novērtējumus un atbilstību Starptautiskajiem finanšu pārskatu standartiem (1.6. tabula).

IAIPF pētījis, ka, attīstoties IA sistēmai pasaulē kopumā kopš 1941. gada, IA funkcija ir l,oti mainījusies. Šìs izmaiņas skārušas gan personālu, kam tiek uzticēts organizācijas IA, gan arī IA darba apjomu un būtību.

Dažās organizācijās pasaulē iekšējie auditori joprojām pārbauda ikdienas finanšu un operatīvās darbības, kas vērstas uz atbilstību, drošību un krāpšanās atklāšanu. Citās organizācijās iekšējiem auditoriem tiek piešķirts augstāka līmeña statuss.

Tālāk autore šajā pētījumā pievēršas valsts pārvaldes iekšèjā audita detalizētākai izpētei, n,emot vērā, ka pētījuma mērḳī ir ietverta priekšlikumu izstrāde IA funkcijas pilnveidošanai valsts tiešajā pārvaldē un pašvaldībās, izmantojot zinātnieku un profesionāḷu veiktos pētījumus par atšksirīgo un kopīgo IA jomā 11 dažādās Eiropas valstīs.

\subsection{2. lekšējā audita pieejas valsts pārvaldē Eiropā}

Eiropas Komisijas ǵenerālsekretāre K. Deja 2016. gadā ir teikusi: "Mūsdienu Eiropā problēmas nerada Baltijas valstis un Polija, uz kurām kādreiz daudzi raudzījās ar neticību un bažām. Mūsdienu Eiropas integrācijā problēmas rada “vecās” Eiropas demokrātijas, kurās ir novecojušas un arvien konservatīvākas sabiedrības, kuras nevēlas pārmaiṇas un kurām ir grūtības pārvarēt ekonomiskos izaicinājumus."

Lai arī 2015. gadā pārskatīts SPPI un 2017. gadā stājušies spēkā papildinātie Standarti, profesionāli IAI joprojām uzskata, ka pastāv neskaidrības attiecībā uz publiskā sektora organizācijām, kas prasa zināmus risinājumus.

Kopsavilkumā par publiskās pārvaldes IKS Eiropas Savienības dalībvalstīs $^{59}$ atspoguḷots, ka gandrīz visās dalībvalstīs valsts pārvaldē darbojas IA funkcija, taču nav aptvertas visas valsts pārvaldes (definējumus un detalizētāku

\footnotetext{
${ }^{59}$ European Comission (2011) Compendium of the Public Internal Control Systems in the EU Member States 2012. Luxembourg: Publications Office of the European Union. Available at: http://ec.europa. eu/budget/library/biblio/publications/2011/compendium_27_countries_en.pdf [cited 09.07.2015.]
} 
skaidrojumu par valsts pārvaldes struktūru sk. 2.1.1. apakšnodaḷā) jomas, piemēram, pašvaldības. Lai panāktu vienotu IA koordināciju un saskaņotību, dalỉbvalstīs ir ieviestas formālas un neformālas metodes. Tradicionālie atbilstības un finanšu auditi aizvien vairāk tiek papildināti ar konsultācijām un efektivitātes auditiem (performance audits), kas prasa profesionālu un labi apmācìtu IA personālu. Dažās dalībvalstīs valsts pārvaldē ir izveidotas audita padomes un/vai IA komitejas. Iekšējās kontroles un audita koordinēšana un saskaņošana valsts sektorā kopumā vai konkrēti valdības sektorā tiek panākta dažādos veidos. Lielākajā dą̧ā valstu šim nolūkam ir izveidotas īpašas koordinējošās struktūrvienības. Apmēram pusē valstu ir izveidots finanšu pēcpārbaudes dienests. Inspekciju struktūra un ziņošanas prasïbas ievērojami atšķiras. ${ }^{60}$

Pēc 27 dalībvalstu aptaujāšanas un informācijas apkopošanas Eiropas Komisija konstatējusi, ka dalībvalstīs ir izveidotas atšķirīgas valsts pārvaldes IKS, jo tām ir jāatbilst visu konstitucionālo tiesību subjektu - vadỉbas, parlamenta un augstākās audita iestādes - pārvaldes struktūrām, kā arī starp šìm pusēm esošajām atbildības saiknēm. Nozīmīgs faktors ir arī valdības iekšienē izveidotā atbildības struktūra. Var nošķirt juridisko atbildỉbu par atbilstību likumiem un noteikumiem un vadības atbildību par mērḳu sasniegšanā izmantoto publisko resursu izmantošanu. Vērā jāṇem arī budžeta un grāmatvedības struktūra. Izvērtējot visu dalïbvalstu administratīvās sistēmas, tika identificēti trīs dažādi vadības atbildības modeḷi iekšējās kontroles vides veidošanā:

1) Eiropas tradicionālais administrācijas modelis - pamatots uz normatīvajiem aktiem un regulējumiem, darba izpildes standartiem. Trūkums vadītājiem ir ierobežota "rīcības brīvība" mērḳu sasniegšanai, un tie vairāk koncentrējas uz atbilstību normatīvajiem aktiem;

2) sabiedrisko vērtību radīšana - modeḷa pamatā ir skaidri noteiktas lomas un funkcijas, kas piel̦auj iestāžu vadītāju brīvu rīcību to sasniegšanā attiecībā uz darba izpildi. Vadītāju darbs tiek novērtēts attiecỉbā uz vinuu ieguldījumu sabiedrības labuma (to definē politikas veidošanas procesā) sasniegšanai;

3) stratēgiskās vadības pieeja - model̦a pamatideja ir tāda, ka visas valsts pārvaldes iestādes ir atšķirīgas, tāpēc katrai nepieciešams savs risinājums, nosakot robežas, kādās iestāde pati var formulēt stratēǵiju un sasniedzamos uzdevumus. Šāda pieeja neuzspiež mērķus "no augšas", un visi iestādes darbinieki ir ieinteresēti to sasniegšanā. ${ }^{61}$

\footnotetext{
${ }^{60}$ Gurkovska V. (2012) Noderīgi: Eiropas Komisijas kopsavilkums par iekšējās kontroles sistēmu 27 ES dalïbvalstīs. IAI Vēstnesis, Nr. 4, 5.-6. lpp.

${ }^{61}$ Turpat.
} 
Iekšējā kontrole visās valstīs netiek izprasta vienādi. Dažās valstīs ir īpašas iekšējās kontroles institūcijas, kas ir neatkarīgas no kontrolējamām iestādēm. Citās valstīs atbildība par iekšējo kontroli tiek deleǵēta attiecīgajai administratīvajai vienībai. Dažās valstīs šì decentralizētā iekšējās kontroles sistēma ir integrēta kā valsts pārvaldes daḷa. Nepieciešamību izveidot iekšējo kontroli, ziṇošanas procesu un riska vadības piemērošanas kārtību var skaidri noteikt likumos un noteikumos, kā arī par tās pamatu var izmantot esošo juridisko bāzi. Decentralizētā sistēmā augstākā līmeṇa vadītājiem ir jāziṇo par iekšējās kontroles sistēmas darbību. Arvien palielinās to valstu skaits, kurās augstākā līmeṇa vadītājiem ir jāievieš sistēmas, kas vada vai mazina riskus, kuri apdraud noteikto mērķu sasniegšanu ${ }^{62}$.

Autore kopā ar pētniekiem S. Grima un P. J. Baldachinno no Maltas Universitātes 2015., 2016. gadā veica pētījumu A Comparative Analysis of the EU Public Sector Internal Audit Methodology and Requirements ${ }^{63}$, kurā analizēja sešas ES dalībvalstis - Latviju, Lietuvu, Igauniju, Poliju, Maltu un Lielbritāniju. Izlase veidoja 24,1\% no kopējā ES 28 valstu skaita, izlasē iekḷaujot Baltijas valstis ar līdzīgiem vēsturiskiem un ekonomiskiem rādītājiem, savukārt Malta tika izvēlēta kā Lielbritānijas kolonija no 1800. gada līdz 1974. gadam, kas ietekmēja publiskā sektora iestādes un to finanšu un ekonomiskās aktivitātes, bet Polija nejauša izvēle - kā Centrāleiropas valsts. Pētījumā autori izvēlējās analizēt un salīdzināt šādus faktorus (1.7. tabula): 1) IAS dibināšanas gads; 2) normatīvie akti un to izmaiņas; 3) audita komitejas; 4) iekšējo auditoru sertifikācija; 5) iekšèjā un ārējā audita sadarbība.

Autore, pētījumu turpinot, valstu izlasi papildina un analizē faktorus visās tajās ES dalībvalstīs, kas pievienojās ES 2004. gadā, kā arī Lielbritānijā, kas ir viena no vecajām dalībvalstīm, turklāt vēsturiski viena no pirmajām ieviesusi IA, par ko liecina daudzās pieejamās publikācijas.

1.7. tabula ietver Eiropas valstu IA faktoru analizzi, identificējot IA izveides gadus, iekšejo auditoru sertifikācijas noteikumus, audita komiteju izveidi un iekšèjā un ārējā audita sadarbības īstenošanu, pamatojoties uz pētījuma 1.2. apakšnodaḷā veikto teorētisko pētījumu.

${ }^{62}$ Gurkovska V. (2012) Noderīgi: Eiropas Komisijas kopsavilkums par iekšèjās kontroles sistēmu 27 ES dalïbvalstīs. IAI Vēstnesis, Nr. 4, 5.-6. lpp.

${ }^{63}$ Faitusa I., Grima S., Baldacchino P. J. (2016) A Comparative Analysis of the EU Public Sector Internal Audit Methodology and Requirements. Proceedings of International Scientific conference New Challenges of Economic and Business Development - 2016, May 12-14, 2016. Riga: University of Latvia, pp. 231-243. 
1.7. tabula. lekšējā audita faktoru analīze Eiropas valstīs (1999-2013)

\begin{tabular}{|c|c|c|c|c|}
\hline Valsts & $\begin{array}{c}\text { lekšējā audita } \\
\text { izveide / } \\
\text { normatīvie akti }\end{array}$ & $\begin{array}{l}\text { lekšējo auditoru } \\
\text { sertifikācija }\end{array}$ & Audita komiteja & $\begin{array}{c}\text { lekšējā audita un ārējā } \\
\text { audita sadarbība }\end{array}$ \\
\hline Latvija* & $\begin{array}{l}\text { 1999. gads. } \\
\text { Ir normatīvie akti }\end{array}$ & $\begin{array}{l}\text { Kopš 2011. gada } \\
\text { jauna sistēma, } \\
\text { kas noteikta } \\
\text { normatīvajos aktos }\end{array}$ & $\begin{array}{l}\text { Viena audita komiteja } \\
\text { kopš 2000. gada }\end{array}$ & $\begin{array}{l}\text { Tiek īstenota, kā noteikts } \\
\text { normatīvajos aktos, ir } \\
\text { noslēgta vienošanās ar } \\
\text { LR VK }\end{array}$ \\
\hline Lietuva & $\begin{array}{l}\text { 2000. gads. } \\
\text { Ir normatīvie akti }\end{array}$ & $\begin{array}{l}\text { 2010. gads - jauna } \\
\text { sertifikācijas } \\
\text { programma, kas ir } \\
\text { brīvprātīga }\end{array}$ & $\begin{array}{l}\text { Parlamentārā audita } \\
\text { komiteja sadarbojas } \\
\text { ar Nacionālo audita } \\
\text { dienestu }\end{array}$ & $\begin{array}{l}\text { Sadarbība noteikta } \\
\text { normatīvajos aktos }\end{array}$ \\
\hline Igaunija & $\begin{array}{l}\text { 2000.-2001. } \\
\text { gads. } \\
\text { Ir normatīvie akti }\end{array}$ & $\begin{array}{l}\text { 2009., } 2011 . \\
\text { gads - ir noteikta } \\
\text { normatīvajos aktos }\end{array}$ & Nav obligāta prasība & $\begin{array}{l}\text { Noteikta normatīvajos } \\
\text { aktos }\end{array}$ \\
\hline Polija & $\begin{array}{l}\text { 2002. gads. } \\
\text { Ir normatīvie akti }\end{array}$ & $\begin{array}{l}\text { 2010. gads - } \\
\text { nacionālais } \\
\text { sertifikācijas } \\
\text { process }\end{array}$ & $\begin{array}{l}\text { Katrā ministrijā (kopā } \\
\text { 17) izveidota audita } \\
\text { komiteja }\end{array}$ & $\begin{array}{l}\text { Noteikta Publisko } \\
\text { finanšu likumā }\end{array}$ \\
\hline Malta & $\begin{array}{l}\text { 2003. gads. } \\
\text { Ir normatīvie akti }\end{array}$ & $\begin{array}{l}\text { Brīvprātīga } \\
\text { starptautiskā } \\
\text { sertifikācija }\end{array}$ & $\begin{array}{l}\text { Audita komiteja nav } \\
\text { noteikta normatīvajos } \\
\text { aktos, bet darbojas } \\
\text { IA riska vadības } \\
\text { direktorāta vienībās }\end{array}$ & $\begin{array}{l}\text { Neoficiāla (informal) } \\
\text { IA un ārējā audita } \\
\text { sadarbība, praksē } \\
\text { darbojas }\end{array}$ \\
\hline Čehija & $\begin{array}{l}\text { 2001. gads. } \\
\text { Ir normatīvie akti }\end{array}$ & $\begin{array}{l}\text { Plāno IA funkciju } \\
\text { aizstāt ar ārējo } \\
\text { (privātā sektora) } \\
\text { auditu }\end{array}$ & Nav ieviestas & $\begin{array}{l}\text { Ārējā audita augstākā } \\
\text { iestāde sadarbojas plānu } \\
\text { gatavošanas posmā }\end{array}$ \\
\hline Kipra & $\begin{array}{l}\text { 2003. gads. } \\
\text { Ir normatīvie akti }\end{array}$ & $\begin{array}{l}\text { Auditori - ar } \\
\text { daudzām } \\
\text { specializācijām un } \\
\text { kvalifikācijām }\end{array}$ & $\begin{array}{l}\text { Ir IA komisārs, kas ziṇo } \\
\text { IA padomei }\end{array}$ & $\begin{array}{l}\text { Noteikta sadarbība } \\
\text { normatīvajos aktos }\end{array}$ \\
\hline Slovākija & $\begin{array}{l}\text { 2001. gads. } \\
\text { Ir normatīvie akti }\end{array}$ & $\begin{array}{l}\text { FM organizē } \\
\text { sistemātiskas, } \\
\text { specializētas } \\
\text { apmācības }\end{array}$ & $\begin{array}{l}\text { Darbojas FM, plāno } \\
\text { ieviest arī citās } \\
\text { ministrijās }\end{array}$ & $\begin{array}{l}\text { Noteikta normatīvajos } \\
\text { aktos. Budžeta } \\
\text { uzraudzības biroja IA var } \\
\text { konsultēt vadību }\end{array}$ \\
\hline Slovēnija & $\begin{array}{l}\text { 2004. gads. } \\
\text { Ir normatīvie akti }\end{array}$ & $\begin{array}{l}\text { Mācības valsts } \\
\text { pārvaldes iekšējiem } \\
\text { auditoriem } \\
\text { organizē FM }\end{array}$ & $\begin{array}{l}\text { Ar jēdzienu "Padome" } \\
\text { (Board) tiek izmantoti } \\
\text { trīs līmeñi: pašvaldību } \\
\text { padomes, audita } \\
\text { padomes un } \\
\text { struktūrvienību vadība }\end{array}$ & $\begin{array}{l}\text { Neoficiāla (informal) } \\
\text { sadarbība }\end{array}$ \\
\hline Ungārija & $\begin{array}{l}\text { 2011. gads. } \\
\text { Ir normatīvie akti }\end{array}$ & $\begin{array}{l}\text { Auditoru reǵistrs. } \\
\text { Nacionālā } \\
\text { sertifikācija }\end{array}$ & $\begin{array}{l}\text { Valsts pārvaldes } \\
\text { iekšējās kontroles } \\
\text { darba grupa }\end{array}$ & $\begin{array}{l}\text { Sadarbojas, izmanto } \\
\text { datus, ārējie auditori } \\
\text { piedalās valsts pārvaldes } \\
\text { iekšējās kontroles darba } \\
\text { grupas sanāksmēs }\end{array}$ \\
\hline Lielbritānija & $\begin{array}{l}\text { 1860. gads. } \\
\text { Ir standarti }\end{array}$ & $\begin{array}{l}\text { Brīvprātīga } \\
\text { starptautiskā } \\
\text { sertifikācija }\end{array}$ & $\begin{array}{l}\text { Audita un risku } \\
\text { nodrošināšanas } \\
\text { komiteja }\end{array}$ & $\begin{array}{l}\text { Dalās ar audita stratē- } \\
\text { ǵijām, lai optimizētu } \\
\text { audita apjomu }\end{array}$ \\
\hline
\end{tabular}

Avots: autores veidota tabula, pamatojoties uz European Commission (2014)

* Detalizētu Latvijas valsts pārvaldes iekšējā audita normatīvo aktu un iekšējā audita procesu izmaiṇu analīzi sk. 2.1. apakšnodal̦ā. 
Iekḷauto valstu analīzē autore galvenokārt ir izmantojusi EK sagatavo ziñojumu Compendium of the Public Internal Control Systems in the EU Member States (turpmāk - EK ziņojums) un citas publikācijas.

Igaunijā atbilstoši EK ziņojumam ${ }^{64}$ IA sistēma ir ieviesta kopš 2001. gada. Galvenie normatīvie akti ir šādi:

1) The Government of the Republic Act (2000), kas ietver iekšèjā audita būtìbu, atbildibu un kompetences;

2) The Auditors Activities Act (2010), kas nosaka iekšejāa audita funkcijas publiskajā sektorā un sabiedriskas nozīmes uzṇēmumos, uzraudzības sistēmas kvalitātes elementus, iekšějo un ārējo novērtējumu, Finanšu ministrijas uzraudzību un profesionālās kvalifikācijas komitejas konsultācijas;

3) Finanšu ministrijas noteikumi "Standartu pieņemšana - Adoption of International Standards for the Professional Practice of Internal Auditing (2003) - svarīgākie IA principi, kas auditoriem jāievēro";

4) grozijumi Local Government Organization Act (2013) - IA ieviešanas nosacijumi pagastos vai pilsētu pašvaldībās.

Igauņu pētnieks $R$. Linnas ${ }^{65}$ uzskata, ka Igaunijā ir svarīgi uzlabot IA profesionālo kvalitāti IA profesijai, bet pašlaik profesija nav ietverta nedz arodizglītības, nedz augstskolu līmeņa izglìīibā. Tāpat $R$. Linnas uzskata, ka Igaunijā IA “eiropeizējas" lıti ātri neatkarīgi no tā ìsās vēstures.

Lietuvā atbilstoši EK ziņojumam un J. Vaitkevicus ${ }^{66}$ apkopojumam IA sistēma tiek regulēta ar vairākiem normatīvajiem aktiem:

1) Iekšèjās kontroles un IA likums, kurā kopš 2002. gada noteikti publiskā sektora iestādes IA mērķi, procedūras un atbildība;

2) Finanšu ministrijas iekšējo auditoru ētikas noteikumi un iekšējā audita metodologija, kas noteikta kopš 2003. gada;

3) IA vadlīnijas (2003), kurās noteikti IA principi, koncepcijas un ieteikumi IA veikšanā, rokasgrāmatu sagatavošanā, novērtēšana, kā arī pietiekamais darbinieku līmenis.

\footnotetext{
${ }^{64}$ European Commission (2014) Compendium of the Public Internal Control Systems in the EU Member States. Second edition, Luxembourg: Publications Office of the European Union, ISBN: 978-922-79-37868-3. Available at: http://ec.europa.eu/budget/pic/compendium/index_en.cfm [cited 09.07.2015.]

${ }^{65}$ Linnas R. (2012) Legal Regulation of Internal audit in Estonia. Conference on Internal Audit and Corporate Governance, April 18-19. Available at: http://www.iacmaster.it/iacgconference2012/ wp-content/uploads/2012/04/Raivo-Linnas.pdf [cited 12.03. 2016].

${ }^{66}$ Vaitkevicius J. (2014) Public sector internal audit in the Republic of Lithuania. Meeting of the INTOSAI Internal Control Standards Subcommittee. Vilnius, 27-28 May.
} 
Iekšèjā audita sistēma valsts pārvaldē Lietuvā ir decentralizēta, taču dažās valsts institūcijās un pašvaldībās tā ir centralizēta. 2014. gadā Lietuvā bija 169 IAS, kas iekḷāva 400 iekšējo auditoru, kuri paveica 1500 auditus gadā (ietverot pašvaldíbas).

Polijā IAS izveidota 2002. gadā Finanšu ministrijā. Finanšu kontroles un IA koordinācijas departaments izveido IA sistēmu. 2002. gadā pieņemtais Publisko finanšu likums par publisko IK ir grozìts 2005., 2006. un 2009. gadā. Kopš 2006. gada - galvenā auditora amats, eksaminācijas komisija un nacionālais sertifikācijas process, kopš 2010. gada katrā no 17 ministrijām ir izveidota audita komiteja, iekšejjā un ārējā audita sadarbība ir noteikta Publisko finanšu likumā par publisko iekšējo kontroli. Polijas IA sistēmu atbilstoši EK ziņojumam nosaka vairāki Polijas normatīvie akti:

1) Publisko finanšu likums nosaka IA lomu publiskā sektora finansēs un ipašumos;

2) publiskā sektora iestāžu IA Standarti (IAI institūta izdotie standarti tiek izmantoti);

3) vadlīnijas - IA rokasgrāmata;

4) IA noteikumi un Ētikas kodekss publiskā finanšu sektora iestādēs.

Iestādes vadītājam jānodrošina apstākḷi, kas ḷauj IA veikt neatkarīgu, objektīvu un efektīvu darbību. Publiskā finanšu sektora iestāžu vadītāji ir atbildīgi par iekšējās vadības un kontroles mehānismu ieviešanu un funkcionēšanu, procedūrām un iekšējiem noteikumiem, piemēram, IA nolikumu.

Lielbritānijāa kas ir viena no ES dibinātājvalstīm, jau 19. gadsimta 60. gados veidojās pašreizējās sistēmas atbildība IA jomā. 1960., 1970. gadā ir bijušas izmaiņas normatīvajos aktos, 1980. gadā Valsts kase izveidojusi centrālu vienību, lai pārraudzìtu IA visā valdībā, un kopš 2013. gada aprị̣a apstiprināti Publiskā sektora iekšèjā audita standarti. Lielbritānijā starptautiskā iekšējā auditora sertifikāta iegūšana ir brīvprātīga, valstī darbojas Audita un risku nodrošināšanas komiteja. Iekšējais audits un ārējais audits dalās ar audita stratēgijām, plāniem un darba pieredzi, lai optimizētu audita apjomu un optimizētu audita slogu auditējamiem. Lielbritānijā IA ir sena vēsture un tradīcijas. Šeit IA nav noteikts ar likumu, bet gan ir ietverts kā obligāta prasība pārvaldỉbas un pasākumu nodrošināšanai saskaņā ar centrālās politikas noteikumiem. İpaša nozīme ir Audita un risku nodrošināšanas komitejai, kuras galvenais uzdevums ir panākt to, lai vadības reakcija un jautājumu risināšana būtu rezultatīva. Lielbritānijas iekšējā audita publiskā sektora standarti (Public Sector Internal Audit Standards), kas ir ļoti līdzīgi Standartiem ar atsevišķiem detalizētiem skaidrojumiem, un Apvienotās Karalistes Valsts kases publicētā Risku nodrošināšanas komitejas 
rokasgrāmata (Risk Assurance Committee Handbook) ir aktuālie dokumenti iekšējiem auditoriem publiskajā sektorā.

Maltas IA sistēmas izveide tika sākta 2003. gadā Iekšêjā audita un finanšu izmeklēšanas departamentā, un tajā bija divi direktorāti - Iekšèjā audita un riska vadības direktorāts iestādēm ar savu IAS, bet Iekšèjā audita centrālais saskaņošanas direktorāts - pārējiem. Iekšêjā audita un finanšu izmeklēšanas akts Ch. 461 ir grozìts 2005. un 2007. gadā. Starptautiskā iekšèjā auditora sertifikāta iegūšana Maltā ir brīvprātīga, Audita komitejas izveide nav noteikta normatīvajos aktos, tomēr darbojas vienībās, kas ietvertas Iekšèjā audita riska vadības direktorāta decentralizētajā struktūrā. Valstī tiek îstenota un efektīvi darbojas neformāla iekšèjā un ārējā audita sadarbība.

Čehijā 2005. gadā valdības Koncepcija par finanšu kontroles sistēmām tika pieņemta kā galvenais valdības politikas dokuments publiskās iekšêjās kontroles attīstībai, pamatojoties uz SIGMA rekomendācijām 2003. gadā. IA regulējums noteikts 2001. gadā Finanšu kontroles likumā, bet 2013. gadā pieņemts jauns Kontroles likums. IA komitejas vai IA padomes Čehijā nav ieviestas, uzskatot to par lieku birokrātiju. Ārējā audita augstākā revīzijas iestāde, gatavojot audita gada plānus, sadarbojas ar IA struktūrvienībām. IA funkcija tiek aizstāta ar ārējo (privātā sektora) audita pakalpojumu. Tiek plānots IA funkciju aizstāt ar finanšu kontroli grāmatvedībā. Ārējā audita nolīgšana tiek pamatota ar publiskā IA kritiku, ka tas nespēj veikt uzraudzības funkciju.

Kipras IA likums ir spēkā kopš 2003. gada. IA dienesta komisārs, ko iecel Ministru padome uz sešiem gadiem, ziņo IA padomei. IA dienesta auditori ir ierēdṇi ar daudzām specializācijām un kvalifikācijām, kas iekḷauj dažādu nozaru inženierus un profesionālus grāmatvežus, kas ir nacionālo un starptautisko institūtu biedri. IA dienests ziņo Valsts Nacionālajam (Kontroles) dienestam, IA ieteikumi tiek ņemti vērā, gatavojot audita gada plānu. IA padomi apstiprina Ministru padome uz trim gadiem, padomē strādā trīs ministri, no kuriem viens ir finanšu ministrs, vēl ir galvenais grāmatvedis un pieredzējis profesionālis no privātā sektora.

Slovākijas 2001. gada Finanšu kontroles likums ietver IA pamatnosacijumus, mērķus un metodiku. Ir IA struktūrvienības vai neatkarīgi iekšējie auditori. FM organizē auditoru sagatavošanu, izmantojot pilna laika apmācību, tālmācību, pašmācību, elektronisko komunikāciju, speciālas tikšanās, dalību konferencēs un semināros, kā arī kursu un forumu apmeklēšanu. Audita komiteja darbojas saskaṇā ar Finanšu kontroles likumu un FM procedūrām. Audita komiteja ir izveidota FM, bet arī citas ministrijas plāno izveidot audita komitejas. 
Slovēnijas IA regulē Publisko finanšu likums, normatīvie akti un vadlīnijas (2004). Sadarbība ar ārējo auditu tiek īstenota kā neoficiāla. Veidojot pozitīvu audita vidi, tiek nodrošināta komunikācija, zināšanu apmaiņa semināros un konferencēs. Audita komitejas (Board) funkcijas tiek īstenotas šādi:

1) ar pašvaldību padomēm, publisko institūciju un aǵentūru publisko fondu padomēm u. c.;

2) ar audita padomēm, ja tādas izveidotas kopējā IA sistēmā;

3) citos gadijumos padome ir vienības vadíba.

Ungārijā par valsts pārvaldes IKS atbildīgs ir Ekonomikas ministrs (Minister for National Economy). Valdības dekrētā par IKS un IA budžeta organizācijām (2011) ir apstiprināti nacionālie standarti, kas iekḷauj visus audita posmus, sākot ar IA uzdevumiem un beidzot ar uzraudzību. Vadlīnijas ietver IA rokasgrāmatu (2013), Ėtikas kodeksu (2012) u. c. Pirmais IA eksāmens auditoriem jākārto pēc gada praktiskā darba pieredzes un otrs - pēc diviem gadiem. Iekšējie un ārējie auditori sadarbojas un papildina viens otra darbu, turklāt, izmantojot ziņojumus, piedalās kopīgās sanāksmēs. Ungārijas valsts pārvaldē ir izveidota publiskās iekšejēās kontroles darba grupa, kuras galvenie uzdevumi ir normatīvo aktu, vadlīniju izstrāde, standartu pieņemšana, IA neatkarīga novērtēšana, ètikas prasību novērtēšana u. c. ${ }^{67}$

Analīze parāda būtiskākās atš̌kirības pētìto valstu IA sistēmu veidošanā. ${ }^{68}$

Autore iesaka Eiropas Komisijas par IA atbildīgajām institūcijām veidot vadlīnijas regulāru pārskatu gatavošanai valsts pārvaldes un pašvaldību IAS, ziņojumā ietverot kvantitatīvos datus par IA, kas būtu salīdzināmi visās ES valstīs, piemēram, personāla kvalifikāciju (darba stāžs, sertificēto iekšējo auditoru skaits), IA procesa efektivitāti (noslēgto iekšējo auditu skaits, gada plāna izpilde \%, termiņu ievērošana audita ziņojumu iesniegšanai), iekšējā audita struktūrvienības pievienoto vērtîbu (ieviesto ieteikumu ipatsvars, auditoru dienu īpatsvars, IAS vadītāja novērtējums, ārējās novērtēšanas rezultāts, IA padomes novērtējums u. c.).

${ }^{67}$ European Commission (2014) Compendium of the Public Internal Control Systems in the EU Member States. Second edition, Luxembourg: Publications Office of the European Union, ISBN: 978-922-79-37868-3. Available at: http://ec.europa.eu/budget/pic/compendium/index_en.cfm [cited 25.03.2018.]

${ }^{68}$ Faitusa I., Grima S., Baldacchino P. J. (2016) A Comparative Analysis of the EU Public Sector Internal Audit Methodology and Requirements. Proceedings of International Scientific conference New Challenges of Economic and Business Development., May 12-14, Riga, University of Latvia, pp. 231-243. 
Tāpat autore secinājusi, ka visas analizētās ES valstis IA darbā izmanto standartus, kas ir atkarīgi no kopējās valsts politikas un katras valsts specifiskajiem noteikumiem.

Katrai analizētajai Eiropas valstij ir sava pieredze un atšķirīgas pozitīvās IA funkcijas vērtību paaugstinošās pieredzes, ko citas valstis varētu pārṇemt. Pamatojoties uz veikto pētījumu, autore izvirza vairākus no citām ES dalībvalstīm pārņemamos pozitīiās valsts pārvaldes IA pieredzes paraugus, ko iespējams izmantot Latvijas valsts pārvaldes IA attīstībai:

1) Igaunijas valsts pārvaldes pieredze IA jomā - IA sistēmas ieviešanas pašvaldībās noteikšana normatīvajos aktos;

2) Lietuvas un Ungārijas valsts pārvaldes pieredze IA jomā - auditoru reg̣istra izveide, sertifikācijas programmas ieviešana iekšējiem auditoriem ar apmācības moduḷiem, pieaicinot universitātes profesorus un praktiķus;

3) Polijas valsts pārvaldes pieredze IA jomā - audita komitejas izveide katrā valsts tiešās pārvaldes ministrijā;

4) Maltas valsts pārvaldes pieredze IA jomā - kā iekšèjā un ārējā audita sadarbïbas šḳērṣ̌u risinājums ir noteikta sadarbība normatīiajos aktos labākai komunikācijai, pietiekami resursi un konsultāciju darba izmantošana;

5) Kipras valsts pārvaldes pieredze IA jomā - iekšējo auditoru dažādu specializāciju un kvalifikāciju noteikšana, kas iekḷauj dažādu nozaru inženierus un profesionālos grāmatvežus, kuri ir nacionālo un starptautisko institūtu biedri;

6) Lielbritānijas valsts pārvaldes pieredze IA jomā - iekšējā un ārējā audita sadarbības organizēšana, daloties ar audita stratēgijāām, plāniem un samazinot organizācijas audita slogu.

Tālāk darba nākamajā nodaļā autore pētījumā ietver risku vadỉbas procesu nozīmi IA veiksmīgai funkcionēšanai.

\section{5. lekšējā audita loma risku vadības procesā}

Risks ir notikums vai faktors, kuru iespējams identificēt un novērtēt un kura iestāšanās negatīvi vai pozitīvi ietekmē projektu. ${ }^{69}$ Tā kā risks ir būtisks, ierobežojošs un vienmēr esošs faktors, risku analīze būtu jāveic neatkarīgi no iespējamības un ierobežojuma analīzes. Lai veiktu risku analīzi, nepieciešama

\footnotetext{
${ }^{69}$ Uzulāns J. (2010) Risku vadība projektu kontekstā. Rīga: Drukātava, 2.-27. lpp., 42.-51. lpp.
} 
informācija par projekta veidu; projekta nozari; vidi, kurā tiks realizēts projekts; valsts ekonomisko un politisko stāvokli un izmaiṇu prognozēm, kā arī projekta specifiskiem apstākḷiem. Risku vērtēšanā jāṇem vērā gan riska ietekme uz projektu, gan iespējamā riska varbūtîba. ${ }^{70}$

Straujas iekšējās un ārējās vides izmaiņas ir aktualizējušas risku vadīšanas jautājumus organizācijās. Lai nodrošinātu šo izmaiṇu vadību, jāizvērtē riski un to ietekme uz iekšējo kontroli, jāṇem vērā gan iekšèjās, gan ārējās vides riski. Risku vadība ir viena no galvenajām vadības atbildības jomām, kas jāisteno organizācijas vadībai un tās darbiniekiem. Efektīva risku vadỉba aptver visu organizāciju kopumā un tiek veidota, lai identificētu iespējamos notikumus, kas nākotnē var ietekmēt organizāciju, saṇemtu kvalitatīvāku informāciju lēmumu pieņemšanai un līdz ar to uzlabotu stratēgisko lēmumu kvalitāti, kā arī vadìtu riskus, lai tie būtu atbilstoši organizācijā piel̦aujamajam riska līmenim. ${ }^{71}$

Autore piekrīt viedoklim ${ }^{72}$, ka IA ir instruments, lai veiktu uzraudzības funkciju, kas nosaka to, ka IA ir svarīga loma risku pārvaldības procesā, bet tas nevar būt atbildīgs par risku pārvaldības procesa ieviešanu un uzturēšanu. IA palīdz vadībai ar uzraudzību, pārbaudi, novērtēšanu, ziņošanu un uzlabojumu ieteikumiem, neatkarīgi pārbaudot un novērtējot to, kā riski tiek pārvaldìti, izvērtējot kontroḷu atbilstību un pārliecinoties, vai kontroles strādā. Risku pārraudzību veic gan IA, gan vadība, par konstatētajām nepilnībām informējot attiecīgo procesa atbildīgo personu un vismaz vienu līmeni augstāko vadìtāju.

Atbilstoši Globālajam ziņojumam ${ }^{73}$ uzsverot katra darbinieka un struktūrvienības lomu un uzlabojot sadarbību, iestādēs nozīmīgi palielinās iespēja identificēt un vadīt riskus pilnā apmērā. Ir svarīgi arī tas, ka organizācijas var pārvaldīt resursus efektīvāk, mazinot darbību pārklāšanos un izvairoties no resursu ieguldījumu dublēšanās.

A. Maršals grāmatā Principles of Economics (1890) konstatējis, ka vadītājs pieņem lēmumus, ne tik daudz pamatojoties uz zināšanām, kā uz ietrenētu instinktu, intuīciju, priekšnojautu, kas, pēc autores domām, saistās ar risku. ${ }^{74}$ Autore piekrīt A. Jaunzema viedoklim, ka darījumi saistās ar risku jeb ir riskanti,

\footnotetext{
${ }^{70}$ Uzulāns J. (2010) Risku vadība projektu kontekstā. Rīga: Drukātava, 2.-27. lpp., 42.-51. lpp.

71 Vērdiṇa G. (2012) Iekšējās kontroles sistēmas pilnveidošanas iespējas studiju programmas īstenošanas procesos. Promocijas darbs vadībzinātnes doktora zinātniskā grāda iegūšanai izglītības vadības apakšnozarē. Rīga: LU PPMF, 252. lpp.

${ }^{72}$ Hāznere A. (2006) Risku pārvaldības process, risku identificēšanas un vērtēšanas metodika. Rīga: SEE semināra materiāli. 3.-4. nov.

${ }^{73}$ Vērtības radīšana sadarbojoties: Aicinājums rīkoties. Globālais ziṇojums - jūlijs, 2014, 10. lpp. The IIA.

${ }^{74}$ Jaunzems A. (2009) Risku analize un vadǐšana. Ventspils: Ventspils Augstskola, 361 lpp.
} 
ja tiem iespējams vairāk nekā viens iznākums, turklāt vismaz divi operācijas iznākumi personai nav ar vienādu derīgumu (utility) jeb nav indiferenti. Kolektīvi lēmumi, kas pieņemti balsojot, mazina katra atsevišķā balsotāja atbildību, tāpēc pamatoti runā par kolektīvo bezatbildību. ${ }^{75}$

Pašvaldību lēmumu pieņemšana domes sēdē, pēc autores domām, pilnībā atbilst iepriekš minētajam. Darba 2.2. nodaḷā autore ir pētījusi pašvaldību IA, kura ieviešana pašvaldībās atbilstoši spēkā esošajiem normatīvajiem aktiem ir atkarīga tikai no deputātu balsojumiem, kas nosaka pieņemtos domes lēmumus.

Koalīciju vara un koalīciju radītie sabiedrības zaudējumi jau pirms 2008.-2013. gada krīzes signalizēja, ka bez esošās politiskās spēles noteikumu radikālas maiṇas pašreizējās tā saucamās demokrātiskās sabiedrības virzās uz pašiznīcināšanos. ${ }^{76}$

Mažoritārās sistēmās ir paredzētas divas balsošanas kārtas: ja pirmajā kārtā neviens no kandidātiem nesaņem balsu vairākumu, notiek otrās kārtas balsošana, kurā piedalās tie divi kandidāti, kas pirmajā kārtā saṇēmuši visvairāk balsu. Viens vai otrs no viṇiem otrajā kārtā saṇem vairāk balsu (neizšḳirti gadījumi ir reti) un tiek ievēlēts. Šîs prakses mērķis ir leǵitimèt ievēlēto kandidātu ar to, ka viņš it kā pārstāv vairāk nekā pusi no iecirkṇa vēlētājiem. Svarīgi minēt, ka "vairāk nekā puse" ir no balsotājiem otrajā kārtā, nevis no vēlētājiem un varbūt pat ne no visiem tiem, kuri balsoja pirmajā kārtā. Tas, protams, kompromitē cenšanos pēc leğitimitātes ${ }^{77}$.

Tāpat Latvijas Republikas likuma "Par pašvaldībām” 19. panta piektajā dạ̣ā par domes priekšsēdētāja vēlēšanām noteikts: "Ja neviens no kandidātiem nesaņem nepieciešamo balsu vairākumu pirmajā kārtā, tiek rīkota atkārtota balsošana par tiem diviem kandidātiem, kuri saṇēmuši visvairāk balsu. Ievēlēts ir tas kandidāts, kurš saṇēmis ievēlēšanai nepieciešamo balsu skaitu. Ja arī otrajā kārtā neviens no kandidātiem nav saṇēmis ievēlēšanai nepieciešamo balsu vairākumu, tiek rīkota balsošana par to kandidātu, kurš otrajā kārtā saṇēmis vairāk balsu." ${ }^{\text {8 }}$

Katra deputāta uzvaru kārtējās balsošanas rezultātā var uzlūkot kā gadījuma lielumu. Autore uzskata, ka pašvaldību IKS kvalitāte ir atkarīga no domes deputātu kompetences un lēmumiem, tāpēc izmanto šo piemēru ar koalīcijām

\footnotetext{
${ }^{75}$ Jaunzems A. (2009) Risku analize un vadǐšana. Ventspils: Ventspils Augstskola, 10.-11. lpp.

${ }^{76}$ Turpat, 330. lpp.

${ }^{77}$ Liepiņš V. Velēšanu sistēmas. Priekšrocības un trūkumi. Pieejams: http://www.lvportals.lv/visi/likumiprakse/186897-velesanu-sistemas-prieksrocibas-un-trukumi/ [skatits 28.01.2017.]

${ }^{78}$ Par pašvaldībām (1994) LR likums. Pieejams: http://www.likumi.lv/doc.php?id=57255 [skatîts 23.11.2017.]
} 
attiecībā uz vēlēšanu rezultātu, kas ir matemātiski aprēķināms, ja zināmi atsevišksi nosacījumi.

Pildot gan pārliecības radīšanas, gan konsultatīvo lomu, IAS var dažādos veidos atvieglot riska vadības procesu. Nosakot IAS pienākumus, ir jāṇem vērā tādi svarīgi faktori kā iespējamā kompleksās riska vadības darbību ietekme uz IAS neatkarību un objektivitāti, minēto darbību spēja uzlabot organizācijas riska vadības, kontroles un pārvaldības procesus. Pieaugot organizācijas riska vadības sistēmas attīstības pakāpei un riska vadībai dziḷāk iesakṇojoties iestādes darbībā, IA pienākumi šefības ziṇā var mazināties. Turklāt, ja organizācijā ir izveidota riska vadības struktūrvienība vai funkcija, IA var dot lielāku pienesumu, vairāk koncentrējoties uz pārliecības radīšanu nekā konsultēšanu. ${ }^{79}$

1.7. attēla centrā ir norādīti IA veicamie konsultatīvie pienākumi attiecībā uz komplekso riska vadību. Jo vairāk IA pāriet uz shēmas lejasdaḷā norādīto darbību veikšanu, jo plašāki IAS konsultatīvie pienākumi var būt.

IA pienākumi attiecībā uz riska vadību:
1) pārliecības sniegšana par riska vadības procesu un riska vērtējumu pareizību;
2) riska vadības procesu vērtēšana un ziņošana par tiem;
3) risku veidu pārskatī̌sana.

Oficiālie IA pienākumi:
1) riska noteikšanas un vērtēšanas sekmēšana;
2) vadības apmācīšana riska pretpasākumu jautājumos;
3) riska vadības darbību saskaņošana un riska pārskatu sniegšana;
4) risku vadības uzturēšana un pilnveidošana, stratēǵijas izstrāde vadībai.

Pienākumi, kas IA nav jāuzṇemas:
1) riska apetītes noteikšana un riska vadības procesu piemērošana;
2) pārliecības sniegšana par risku vadības vārdā, riska pretpasākumu lēmumu pieņemšana un riska pretpasākumu realizēšana;
3) atbildības uzṇemšanās par riska vadību.

\section{7. attēls. lekšējā audita pienākumi kompleksās riska vadības ietvaros}

Avots: autores veidots saskaṇā ar IAI oficiālo nostāju (2010).

\footnotetext{
${ }^{79}$ IAI oficiālā nostāja par iekšèjā audita lomu kompleksajā uzṇēmuma riska vadībā. Pieejams: http://www.iai.lv/files/Biedriem/standarti/2010/ippf_pp_role_of_ia_in_erm_lv_01.09.2010.pdf [skatits 23.08.2012.]
} 


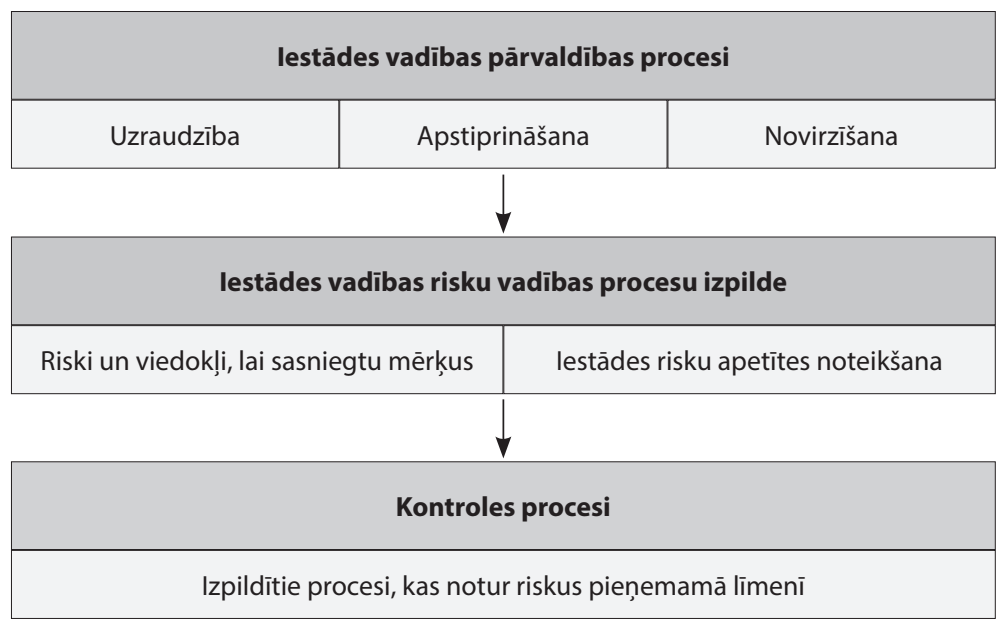

\section{8. attēls. Pārvaldības, risku vadības un kontroles procesa saistība}

Avots: autores veidots, pamatojoties uz Ray (2009).

Autore piekrīt IAI oficiālajam viedoklim par IA lomu kompleksajā uzñēmuma riska vadībầ ${ }^{80}$, proti, galvenais apsvērums, nosakot, vai IAS sniegtās konsultācijas ir apvienojamas ar pārliecības sniegšanas pienākumiem, ir tas, vai IAS pilda vadības pienākumus. IAS var sniegt konsultācijas tikai tad, ja tā neveic faktiskas riska vadības darbības, kas ir vadības pienākums, kā arī tad, ja augstākā vadība ir apstiprinājusi un aktīvi atbalsta riska vadības realizēšanu. Ja IAS palīdz vadībai izveidot vai uzlabot riska vadības procesus, struktūrvienības plānā būtu ieteicams skaidri un precīzi norādīt plānu un grafiku, atbilstoši kuram pilna atbildība par riska vadības pasākumiem tiks nodota vadībai.

IA nozīmīga loma ir pārvaldỉbas, risku vadības un kontroles procesa novērtēšanā. IA palīdz iestādei sasniegt tās stratēgiskos mērķus, pateicoties pārvaldības, risku vadības un kontroles procesa novērtěšanai. 1.8. attēla modelis atspoguḷo visu minēto procesu mijiedarbību un sakarības.

Pārvaldības, risku vadỉbas un kontroles procesi pastāv, lai nodrošinātu adekvātu to risku kontroli, kas apdraud iestādes mērķu sasniegšanu. IA nodrošina šos procesus ar to novērtēšanu - ar ziņošanu par atklātajiem trūkumiem un ieteikumu sniegšanu vadībai. Lai parādītu, kā IA uzlabo organizācijas spēju sasniegt stratēgiskos mērķus, ir jāsaprot, kā IA iederas organizācijas vērtību

\footnotetext{
${ }^{80}$ IAI oficiālā nostāja par iekšējā audita lomu kompleksajā uzṇēmuma riska vadībā. Pieejams: http://www.iai.lv/files/Biedriem/standarti/2010/ippf_pp_role_of_ia_in_erm_lv_01.09.2010.pdf [skatits 23.08.2012.]
} 
ķēdē. Lai precīzi identificētu audita subjektu, jau sagatavojot audita gada plānu ir jāvērtē, kas tiks izvēlēts: auditēt organizācijas struktūrvienību, atbalsta funkciju vai kādu specifisku gada laikā uzsākto vai ieviesto projektu.

Visbiežāk auditam tiek izvēlēts subjekts, kas pamatots ar riska novērtējumu, ko paredz Standarti, nosakot, ka IA gada plāns jāsastāda, pamatojoties uz risku novērtējumu un plānā nosakot audita prioritātes. Projekta riski ir būtisks un ierobežojošs, vienmēr esošs faktors, un risku analīze būtu jāveic neatkarīgi no iespējamības un ierobežojuma analīzes.

Autore piekrìt PricewaterhouseCoopers nostājai ${ }^{81}$ - lai veiktu risku analīzi, nepieciešama informācija par auditējamo struktūrvienību, nozari; valsts ekonomisko un politisko stāvokli un izmainu prognozēm, kā arī specifiskajiem apstākḷiem. Risku vērtēšanai izmanto riska ietekmi uz projektu un riska varbūtību. Risku ietekme var būt zema, vidēja un liela (jeb augsta).

Maza risku varbūtība iestājas, kad, veicot plānošanu, riska notikumu var ignorēt; vidēja - kad, veicot plānošanu, ir jāieplāno riska notikuma ietekmei atbilstoša laika un resursu rezerve vai jāveic pasākumi riska notikuma varbūtības samazināšanai, bet liela - kad, veicot plānošanu, ir jāieplāno riska notikuma ietekmei atbilstoša vidēja lieluma laika un resursu rezerve un jāveic pasākumi riska notikuma varbūtības samazināšanai.

Uz risku balstīts audits tiek sākts ar iestādes vai projekta mērķu un atbilstošo sasniedzamo rādītāju identificēšanu, kas tiek izmantoti, lai novērtētu izpildi, uzmanību vēršot uz organizācijas darbỉbas riskiem, kas varētu apdraudēt spēju sasniegt definētos mērķus, un kontrolēm, kurām jāpastāv, lai palielinātu iespēju, ka definētos mērķus var sasniegt. IA sniegtie ieteikumi ir vērsti uz kontroles mehānisma uzlabošanu, lai mazinātu riska iestāšanās varbūtību.

Mērķiem ir jābūt skaidri noteiktiem un izteiktiem apakšmērķos, kā arī relatīvi konstantiem, mainot mērķus, ja rodas lielas izmaiṇas. Uz risku balstìta IA posmi ir plānošana, novērtēšana, rezultātu sniegšana un uzraudzība.

Plānošana sevī ietver mērķu identificēšanu, izpratnes iegūšanu, vienošanos ar vadību par audita jomu, audita veikšanas periodu, riska/kontroles matricas izstrādāšanu katram auditējamam (jomai) un audita programmas sagatavošanu. Novērtēšana ietver kontroḷu testēšanu ar mērķi noteikt, vai kontroles ir efektīvas - vai tās faktiski pastāv un darbojas, kā arī testu veikšanu, lai gūtu pārliecību, vai funkcijas/projekta mērķus var sasniegt, pastāvot esošajām kontrolēm. Rezultātu sniegšanā tiek izstrādāts iekšèjā audita ziņojums, bet par konstatējumiem

${ }^{81}$ Latvijas Republikas Finanšu ministrija, PricewaterhouseCoopers (2006) LR Izpildes novērtējuma auditi. 
1.8. tabula. Riski, kontroles un skaidrojumi

\begin{tabular}{|c|c|c|c|c|c|}
\hline Mērķis & Risks & $\begin{array}{l}\text { lestāšanās } \\
\text { varbūtība un } \\
\text { ietekme }\end{array}$ & $\begin{array}{l}\text { Faktiskās } \\
\text { kontroles }\end{array}$ & $\begin{array}{c}\text { Kontroles } \\
\text { piemērotības } \\
\text { novērtējums }\end{array}$ & $\begin{array}{c}\text { Kontroles } \\
\text { efektivitātes } \\
\text { testi }\end{array}$ \\
\hline $\begin{array}{l}\text { Attiecībā uz } \\
\text { ko tiks veikta } \\
\text { detalizēta } \\
\text { novērtēšana }\end{array}$ & $\begin{array}{l}\text { Kas var mazināt } \\
\text { spēju sasniegt } \\
\text { definētos } \\
\text { mērḳus (iekšēji } \\
\text { un ārēji faktori). } \\
\text { Sākotnējie riski }\end{array}$ & $\begin{array}{l}\text { Riska līmeña } \\
\text { novērtējums, } \\
\text { apsverot riska } \\
\text { iestāšanās } \\
\text { varbūtību un } \\
\text { ietekmi, kāda } \\
\text { varētu tikt radīta, } \\
\text { ja risks iestātos. } \\
\text { Novērtējuma } \\
\text { skala - zems, } \\
\text { vidējs vai augsts } \\
\text { līmenis }\end{array}$ & $\begin{array}{l}\text { Faktiski } \\
\text { pastāvošās } \\
\text { kontroles, } \\
\text { kas iestādē } \\
\text { darbojas. } \\
\text { Intervijas, kurās } \\
\text { novērtē to, kas } \\
\text { faktiski tiek } \\
\text { veikts }\end{array}$ & $\begin{array}{l}\text { Novērtē, vai } \\
\text { teorētiski } \\
\text { paredzētās } \\
\text { kontroles } \\
\text { samazinātu } \\
\text { risku līdz } \\
\text { pien,emamam } \\
\text { līmenim }\end{array}$ & $\begin{array}{l}\text { Testi, lai } \\
\text { novērtētu } \\
\text { pastāvošo } \\
\text { būtisko } \\
\text { kontroḷu } \\
\text { efektivitāti - } \\
\text { vai kontrole } \\
\text { ir ieviesta un } \\
\text { darbojas }\end{array}$ \\
\hline
\end{tabular}

Avots: autores veidota tabula, pamatojoties uz Latvijas Republikas Finanšu ministrijas datiem (2006).

un ieteikumiem ieteicams ziņot audita laikā, nevis audita noslēgumā, un uzraudzība tiek veikta attiecībā uz IA rezultātā izteikto ieteikumu ieviešanu.

Risku un kontroḷu skaidrojumi (1.8. tabula) tiek piemēroti gan organizācijas vērtības, organizatoriskās vides (soft) kontrolēm, gan politikas, procedūru dokumentu (hard) kontrolēm. Tas palīdz nodrošināt to, ka visi būtiskākie riski ir identificēti, kā arī palīdz uzlabot audita darba produktivitāti, fokusējoties tikai uz svarīgākajām jomām, par kurām vadība ir izteikusi bažas. Lai varētu efektīvi vērtēt pastāvošos vai iespējamos riskus, funkcija vai darījums ir jāanalizē no sākuma līdz brīdim, kad to var uzskatīt par pabeigtu, uzdodot šādus jautājumus: kādas kḷūdas ir iespējamas, kas var notikt un kādas nepilnības iespējamas? ${ }^{82}$

Standarti nosaka to, ka IAS ir jāvērtē efektivitāte un jāsekmē riska vadības procesu uzlabošana. Riska valdības process ir efektīvs tad, ja iekšējais auditors konstatē, ka:

- organizācijas mērḳi atbilst organizācijas misijai un veicina tās īstenošanu;

- ir identificēti un novērtēti būtiski riska veidi;

- ir izraudzīti piemēroti riska novēršanas pasākumi, kas atbilst organizācijas riska apetītei; un

- visā organizācijā ir nodrošināts tas, ka laikus tiek iegūta un izplatīta būtiska informācija par risku, tādējādi dodot iespēju darbiniekiem un vadībai veikt savus pienākumus.

\footnotetext{
${ }^{82}$ Latvijas Republikas Finanšu ministrija, PricewaterhouseCoopers (2006) Izpildes novērtējuma auditi.
} 
IAS var apkopot šo informāciju, lai izmantotu darba dokumentos, veicot dažādus uzdevumus, nodrošinot izpratni par iestādes riska vadību un efektivitāti. IAS jāizvērtē ar iestādes pārvaldību, darbībām un informācijas sistēmām saistìtais risks attiecībā uz šādiem kritērijiem:

- organizācijas stratēégisko mērḳu sasniegšana;

- finanšu un operatīvās informācijas ticamība un konsekvence;

- darbỉbu un programmu efektivitāte un lietderība;

- aktīvu aizsardzība; un

- atbilstība normatīvajiem aktiem, politikām, procedūrām un līgumiem. ${ }^{83}$

IAS ir jānovērtē krāpšanas iespējamība un tas, kā iestāde ierobežo krāpšanas risku. Veicot konsultatīos darba uzdevumus, iekšējiem auditoriem risks ir jāizvērtē atbilstīgi darba uzdevumu mērḳiem un jābūt piesardzīgiem attiecībā uz citiem nozīmīgiem riska veidiem. Novērtējot iestādes riska vadības procesus, iekšêjiem auditoriem ir jāizmanto konsultēšanas darba uzdevumos iegūtās zināšanas par risku. Palīdzot vadībai izveidot vai uzlabot riska vadības procesus, iekšējiem auditoriem ir jāatturas no jebkādu vadības pienākumu uzṇemšanās un risku faktiskās vadības. ${ }^{84}$

Autore secina, ka Standarti nosaka detalizētas un konkrētas iekšèjā auditora darbības gan dažādu organizācijas sistēmu risku identificēšanā, gan risku izvērtēšanā, gan ziṇošanai vadībai.

\section{1. nodal̦as kopsavilkums}

IA pirmsākumi saistās ar grāmatvedības rašanos jau 4000.-3500. g. p.m.ē., mūsdienu IA pirmsākumi meklējami 1941. gadā ar IAI dibināšanu ASV. IA attīstību pasaulē autore iedala trīs fāzēs:

1) pirmsākumi līdz IAI dibināšanai;

2) globālā IA iezīmes, IAI dibināšana un vēsturiskā attīstība;

3) IT periods - 21. gadsimts.

Lielu ieguldījumu IA un iekšejā auditora profesijas attīstībā devuši vairāki zinātnieki un praktiķi: līdz 1941. gadam IA piekritēji - dažādu darbu autori, zinātnieki un praktiḳi no ASV un Lielbritānijas - A. Collins, V. Z. Brink, C. A. Smith, kā arī pēc IAI dibināšanas L. B. Sawyer, M. A. Dittenhofer u. c. Jēdzieni "audits" un "revīzija" tiek lietoti un attiecināti gan uz IA, gan uz ārējo auditu. Literatūrā jēdzieni "audits" un "revīzija” tiek skaidroti kā

${ }^{83}$ Latvijas Republikas Finanšu ministrija, PricewaterhouseCoopers (2006) Izpildes novērtējuma auditi. ${ }^{84}$ Iekšējā audita profesionāāās prakses starptautiskie standarti (standarti). IAI. Pieejams: https://global. theiia.org/translations/PublicDocuments/IPPF-Standards-2017-Latvian.pdf [skatits 30.06.2017.] 
saimnieciskās darbības, grāmatvedības un finanšu pārskatu pārbaudes, kas attiecas uz ārējo auditu vai ārējo revīziju, taču termins "iekšējais audits" latviešu valodā $A k a d T e r m$ datubāzē netiek skaidrots un definēts. IA definīcijas un iekšèjā auditora pienākumi ir attīstīti no 1947. gada līdz 1999. gadam. Sākotnējā definīcija attiecās uz grāmatvedības un finanšu darbībām, kā arī uz darbības veidiem, kad iekšējā auditora sākotnējais uzdevums bija padomdevēja loma, bet vēlāk IA loma tika papildināta ar neatkarīgu pārliecības radīšanas funkciju un procesu efektivitātes novērtēšanu.

Latvijas Republikas normatīvajos aktos ietvertā IA definīcija ir virzìta un akcentē IKS novērtēšanu, ietverot, pēc autores domām, trīs galvenās jomas: darbību efektivitāte un produktivitāte; finanšu pārskatu ticamība un atbilstība normativijiem aktiem.

Autore piedāvā starptautisko un 40 valodās oficiāli tulkoto IAI definīiju iekḷaut AkadTerm datubāzē, ņemot vērā, ka pašlaik tur nav iekḷauts šì jēdziena skaidrojums.

Iekšèjā kontrole un IA Eiropas valstīs netiek izprasti vienādi. Dažās valstīs ir īpašas iekšējās kontroles institūcijas, kas darbojas neatkarīgi no kontrolējamām iestādēm, savukārt citās valstīs šì funkcija tiek delegèèta kādai atbilstošai institūcijai. Analizējot Eiropas valstu IAS veidošanos un darbību, konstatēts, ka ikvienai valstij ir sava pieredze, bet atškirīgas ir IA funkcijas, ko citas valstis var pārņemt.

Pašvaldību IKS ir atkarīga gan no normatīvo aktu kopuma, gan pašvaldības rīcībā esošā finansējuma, gan no domes deputātu kompetences un pieņemtajiem lēmumiem, kā arī izpratnes par iekšèjās kontroles lietderīgumu, savukārt IAS, pildot pārliecības radǐšanas un/vai konsultatīvo lomu, var atvieglot riska vadību ar procesu novērtēšanu.

Nākamajā darba nodal̦ā autore ir pētijusi Latvijas valsts tiešās pārvaldes mehānismu un IA pieejas, to attīstību kopš ieviešanas, jo šajās iestādēs IA darbība tiek regulēta ar normatīvajiem aktiem. Autore ir pētijusi Latvijas pašvaldību sistēmu un IA pieejas Latvijas pašvaldībās, kas ir atvasinātās publiskās personas, kurām normatīvajos aktos ir noteikta zināma darbošanās brīvība, taču to finanšu un ekonomisko darbību pārbauda un kontrolē gan LR VK, gan zvērināti revidenti, taču IA ieviešana nav noteikta kā obligāta prasība. 


\section{LATVIJAS VALSTS PĀRVALDES IEKŠĒJĀ AUDITA SISTËMAS ATTİSTİBAS IZVËRTËJUMS}

\section{1. lekšējā audita sistēma Latvijas valsts pārvaldē}

\subsubsection{Latvijas valsts pārvaldes sistēmas raksturojums}

Katra ES dalībvalsts var brīvi veidot sev piemērotāko administratīvo sistēmu. Publiskās pārvaldes jomā ES nav kopīgu noteikumu, kas regulētu dalībvalstu administratīvo sistēmu. ${ }^{85}$

Latvijas Republikas Valsts pārvaldes iekārtas likums nosaka to, ka valsts pārvalde ir organizēta vienotā hierarhiskā sistēmā. Tiešās pārvaldes institucionālo sistēmu veido un tās darba organizāciju nosaka Ministru kabinets (turpmāk - MK), kas izveido, reorganizē un likvidē tiešās pārvaldes iestādi. Valsts pārvaldes iekārtas likuma 4. panta pirmā daḷa noteic, ka Latvijas Republika (turpmāk - LR) kā sākotnējā publiskā persona valsts pārvaldes jomā darbojas ar tiešās un pastarpinātās pārvaldes iestāžu starpniecību.

Kopējā Latvijas valsts pārvaldes shēma, ko izveidojusi un publicējusi LR Valsts Kanceleja, parāda valsts tiešās pārvaldes un publisko atvasināto personu vietu valsts pārvaldē (2.1. attēls). Atbilstoši Valsts pārvaldes iekārtas likumam pastarpinātās pārvaldes iestāde var pildìt noteiktus valsts pārvaldes uzdevumus, kuri ir LR kompetencē, bet kuru izpilde nodota attiecīgajai atvasinātajai publiskai personai vai iestādei pašai. Šādā gadījumā iestāde pārstāv LR. Tiešās pārvaldes institucionālā sistēmā neietilpst tiesu varas un likumdošanas varas institūcijas un to veidotās iestādes. Tiešās pārvaldes institucionālā sistēma tiek nodalīta no pastarpinātās pārvaldes sistēmas.

Valsts tiešajā pārvaldes sistēmā ietilpst (2.1. attēls):

1) ministrijas, īpašu uzdevumu ministru sekretariāti un Valsts kanceleja kā nozaru vadošās (augstākās) iestādes;

${ }_{85}^{85}$ Vanags E. (2007) Valsts pārvaldes reformas àrvalstīs un Latvijā. Rīga: Latvijas Statistikas institūts, 35.36. lpp. 
2) visas iestādes (izņemot valsts kapitālsabiedrības), kuras ir izveidojis MK, kas atrodas MK locekḷa padotībā (valsts aǵentūras un publiskie nodibinājumi);

3) ar likumu izveidotās tiešās pārvaldes iestādes - Korupcijas novēršanas un apkarošanas birojs, Sabiedrības integrācijas fonds, Pārresoru koordinācijas centrs, Satversmes aizsardzības birojs.

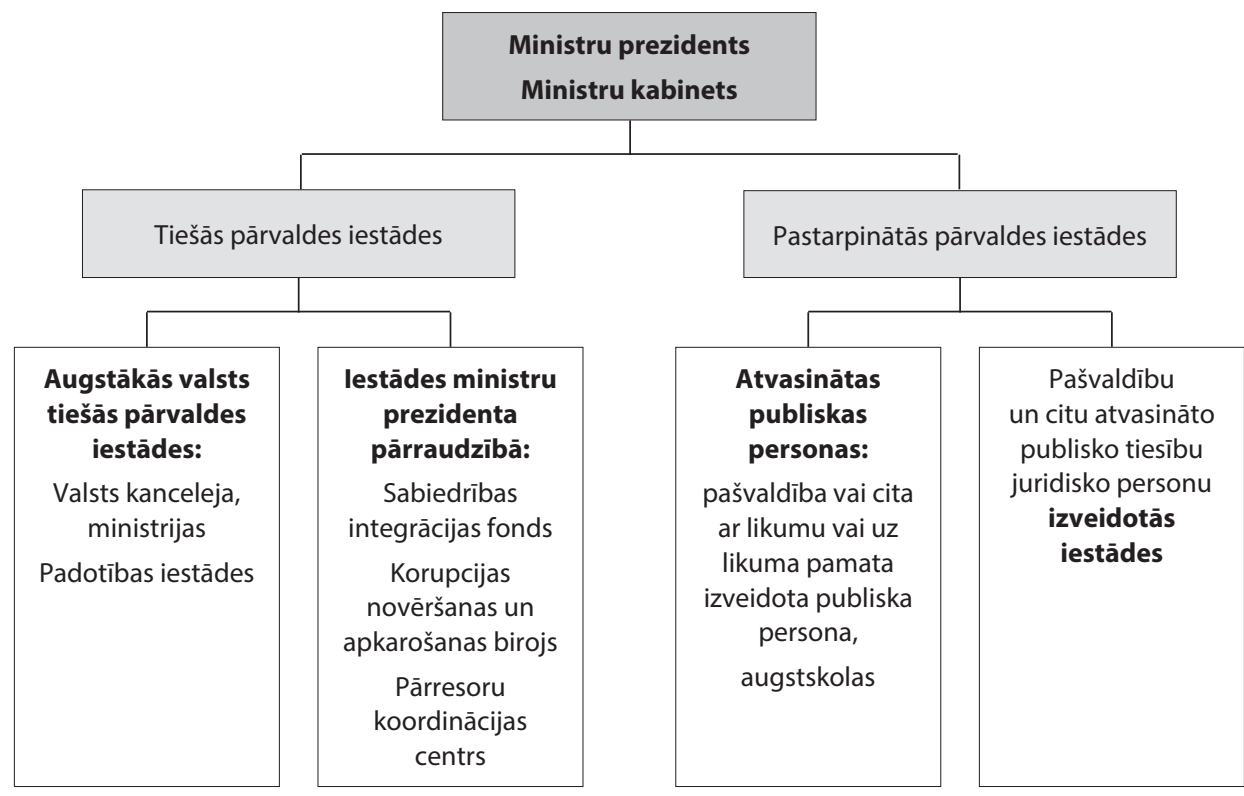

\section{1. attēls. Latvijas valsts pārvaldes kopējās sistēmas shēma (2018)}

Avots: autores veidota, pamatojoties uz Valsts tiešās pārvaldes iestāžu datubāzes informāciju (2018).

Iestādes, kuras neietilpst tiešās pārvaldes sistēmā, ir šādas: atvasināto publisko tiesību juridiskās personas (augstskolas, pašvaldības, brīvostu pārvaldes); atvasināto publisko tiesību juridisko personu izveidotās iestādes, t. i., pašvaldību un augstskolu izveidotās iestādes; ar likumu izveidotās iestādes ārpus MK padotības (Nacionālā radio un televīzijas padome, Centrālā vēlěšanu komisija, Valsts cilvēktiesību birojs, Latvijas Banka); LR institūcijas, kas minētas Satversmē (Valsts prezidents, Saeima, MK, LR VK), kā arī Valsts prezidenta un Saeimas veidotās iestādes. ${ }^{86}$

\footnotetext{
${ }^{86}$ Vanags E. (2007) Valsts pārvaldes reformas ārvalstīs un Latvijā. Rīga: Latvijas Statistikas institūts, 35.36. lpp.
} 
MK 2014. gada 30. decembra rīkojuma Nr. 827 "Par Valsts pārvaldes politikas attīstības pamatnostādnēm 2014.-2020. gadam" " mērḳis ir efektīva, pieejama, inovatīva, profesionāla un uz rezultātu vērsta valsts pārvalde, savukārt atsevišķie apakšmērķi ir šādi: nodrošināta pilnvērtīga klātienes un neklātienes pakalpojumu pieejamība; profesionāli, motivēti un godīgi valsts pārvaldē nodarbinātie; efektīvi funkcionējoša attīstības plānošanas sistēma. ${ }^{88}$ Rìkojumā, pèc autores domām, ḷoti svarīgi ir noteiktie uzdevumi valsts un privātā sektora sadarbības uzlabošanā: izstrādāt grozījumus Valsts pārvaldes iekārtas likumā, precizējot izpratni par delegeéšanas institūtu, arī sniegt ministrijām atbalstu delegeéšanas procesa nodrošināšanā, izstrādājot delegeeššanas līguma pamatparaugu un izveidojot efektivitātes rādītāju katalogu.

SIGMA veikto pētijumu rezultāti ${ }^{89}$ saskan ar EK nostāju, ka jaunajām dalībvalstīm jāuzlabo administratīvā spēja vairākās jomās, kā pirmo izvirzot iekšèjo finanšu kontroli. ES dalībvalstīm izvirzìtie galvenie principi publiskās pārvaldes jomā ir šādi: 1) likumība (tiesiskums); 2) uzticība un prognozējamība; 3) noteiktība un stabilas procedūras; 4) elastîbas un rīcības brīvība; 5) cieņa pret personu; 6) atklātība un caurspīìigums; 7) atbildība un atskaitīšanās; 8) diskriminācijas likvidēšana; 9) taisnīgums un godīgums; 10) efektivitāte un racionālisms; 11) vadības kompetence; 12) administratīvā (organizatoriskā) kapacitāte; 13) sabiedrības iesaistī̌sana pārvaldes procesā..$^{90}$

Autore uzskata, ka visi principi ir demokrātiskas pārvaldības pamats un Latvijā līdz visu šo principu izpildei vēl jāpieliek daudz pūḷu, jo valsts pārvaldes sektorā apzināti vai neapzināti joprojām tiek piel̦autas daudzas kḷūdas.

2.1. tabulā autore apkopojusi politikas rezultātus un rezultatīvos rādītājus, iekḷaujot, pēc autores domām, Latvijas politikas prioritāšu darbības rezultātus un rezultatīvos rādītājus par periodu no 2013. līdz 2020. gadam. Autore uzskata, ka ḷoti svarīgs politikas mērḳis ir šāds: Valsts pārvalde Latvijā ir pieejama, inovatìva, profesionāla un uz rezultātu vērsta, ko ir iespēja sasniegt, paaugstinot kvalitāti un atbildību visu līmeṇu strādājošo un vadītāju darbā.

${ }^{87}$ Par Valsts pārvaldes politikas attīstîbas pamatnostādnēm 2014.-2020. gadam. MK rīkojums Nr. 827, Rīgā, 2014. gada 30. decembrī (prot. Nr. 69, 47.§). Pieejams: http://likumi.lv/doc.php?id=271384 [skatîts 10.08.2015.].

${ }^{88}$ Turpat.

${ }^{89}$ SIGMA (2005) Ekspertu palīdzība valsts iekšējā audita sistēmai Latvijā. SIGMA ekspertu sagatavotais detalizēts ziņojums, aprīlis, 88. lpp.

${ }^{90}$ Vanags E. (2007) Valsts pārvaldes reformas àrvalstīs un Latvijā. Rīga: Latvijas Statistikas institūts, 35.36. lpp. 


\section{1. tabula. Latvijas politikas mērḳis, darbības rezultāti un to rezultatīvie rādītāji} (2013-2020)

\begin{tabular}{|c|c|c|c|c|}
\hline Politikas mērķis & \multicolumn{4}{|c|}{$\begin{array}{c}\text { Efektīva, pieejama, inovatīva, profesionāla } \\
\text { un uz rezultātu vērsta valsts pārvalde }\end{array}$} \\
\hline Politikas rezultāts & $\begin{array}{c}\text { Rezultatīvais rādītājs (Latvijas } \\
\text { novērtējums atsevišḱos WGI* } \\
\text { parametros) }\end{array}$ & 2013 & 2017 & 2020 \\
\hline \multirow{2}{*}{$\begin{array}{l}\text { Valsts pārvalde Latvijā ir } \\
\text { pieejama, inovatīva, profesionāla } \\
\text { un uz rezultātu vērsta }\end{array}$} & Publiskās pārvaldes efektivitāte & $0,83(2012)$ & 0,90 & 1,00 \\
\hline & Likumdošanas kvalitāte & $1,00(2012)$ & 1,15 & 1,30 \\
\hline $\begin{array}{l}\text { Valsts pārvaldē nodarbināto } \\
\text { skaits ir atbilstošs vajadzībām un } \\
\text { ar tendenci nepalielināties }\end{array}$ & $\begin{array}{l}\text { Vispārējās valdības sektorā } \\
\text { nodarbināto īpatsvars no kopējā } \\
\text { iedzīvotāju skaita }\end{array}$ & $9,1 \%$ & $8,6 \%$ & $8 \% * *$ \\
\hline Darbības rezultāti & Rezultatīvais rādītājs & 2013 & 2017 & 2020 \\
\hline $\begin{array}{l}\text { Nodrošināta pilnvērtīga klātienes } \\
\text { un neklātienes pakalpojumu } \\
\text { pieejamība }\end{array}$ & $\begin{array}{l}\text { Latvijas vērtējums e-pārvaldes } \\
\text { indeksā (vieta)***}\end{array}$ & $31(2014)$ & 28 & 23 \\
\hline \multirow[b]{2}{*}{$\begin{array}{l}\text { Valsts pārvaldē strādā } \\
\text { profesionāli, motivēti } \\
\text { un godīgi nodarbinātie }\end{array}$} & $\begin{array}{l}\text { Atlīdzības (valsts un pašvaldības) } \\
\text { ippatsvars IKP***** }\end{array}$ & $7,5 \%$ & $7,1 \%$ & $6,8 \%$ \\
\hline & $\begin{array}{l}\text { Profesionālo kompetenci } \\
\text { paaugstinājušo personu skaits } \\
\text { labāka regulējuma izstrādē mazo } \\
\text { un vidējo komersantu atbalsta, } \\
\text { korupcijas novēršanas un ēnu } \\
\text { ekonomikas mazināšanas jomās }\end{array}$ & 0 & 4000 & 17598 \\
\hline
\end{tabular}

* WGI - Worldwide Governance Indicators - pasaules pārvaldes rādītāji.

** Rādītāja vērtība saskaṇota ar Latvijas Stratēg̀iskās attīstības plāna 2010.-2013. gadam iekḷauto rādītāju.

*** ANO e-pārvaldes indekss. Pieejams: http://unpan3.un.org/egovkb/en-us/Data/Country-Information/id/93Latvia.

**** Rādītājs aprēḳināts, ṇemot vērā konkrētajā laikā noteikto IKP prognozi.

Avots: autores veidota tabula, pamatojoties uz Valsts pārvaldes politikas attīstības pamatnostādnēm 2014.-2020. gadam, MK (2014).

\subsection{2. lekšējā audita normatīvais regulējums Latvijas valsts tiešajā pārvaldē}

Latvijas valsts tiešajā pārvaldē IA funkcijas ieviešana tika sākta 1999. gadā, kad iestāšanās Eiropas Savienībā noteica stingras prasības - IA ieviešanu kā obligātu atbilstoši 1995. gada 18. decembra Eiropas Padomes nolikumam Nr. 2988/95 par Eiropas Kopienu finanšu interešu aizsardzību ietvertajām prasībām. 1999. gada 9. februārī valdība pien̦ēma lēmumu par to, ka Finanšu ministrija ir atbildīga par IA vispārējo koordināciju un attīstîbu Latvijas valsts pārvaldē. $K$. W. Wade konsultāciju un audita apmācību centrs veicināja IAS veidošanu valsts pārvaldē, sniedzot intensīvo kursu Latvijas valsts pārvaldē 24 topošajiem iekšējiem auditoriem. 


\section{2. tabula. lekšejjā audita metodiskie dokumenti, procesi un rezultāti 1999. gadā Latvijas valsts tiešajā pārvaldē}

\begin{tabular}{|l|l|}
\hline \multicolumn{1}{|c|}{ Metodiskais dokuments/process } & \multicolumn{1}{c|}{ Sagaidāmais rezultāts } \\
\hline lekšējā audita rokasgrāmata & Vienota iekšēau audita metodika visā valsts pārvaldē \\
\hline leteikumi riska novērtēšanas metodikai & Vienota pieeja - salīdzināmi, pārskatāmi \\
\hline Salīdzinošās pārbaudes & $\begin{array}{l}\text { Reguāra izvērēšana, nepilnību savlaicīga } \\
\text { konstatēšana }\end{array}$ \\
\hline $\begin{array}{l}\text { Tehnoloǵijas izveide (ieteikumu datubāze, } \\
\text { auditoru darba laika uzskaite) }\end{array}$ & Palielināta darba efektivitāte \\
\hline Ikmēneša auditoru tikšanās & Darba kontaktu veicināšana \\
\hline
\end{tabular}

Avots: autores tabula, pamatojoties uz Latvijas Republikas normatīvo aktu prasībām.

1999. gada aprīlī ar Phare ekspertu palīdzību izstrādāti un 5. oktobrī ir pieņemti MK noteikumi Nr. 342 "Noteikumi par iekšējo auditu" un MK noteikumi Nr. 346 "Iekšéjā audita padomes nolikums”. Šajā laikā noteikti iekšêjā audita četri galvenie attīstības virzieni: apmācību organizēšana (mācību stratēgijas, sertifikācijas sistēmas izstrāde), tiesiskā pamata izstrāde, metodikas attīstība un visu ministriju IAS pilnveidošana. Autore veikusi valsts tiešās pārvaldes sākotnējā iekšèjā audita metodisko dokumentu klasifikāciju, atsevišḳi izdalot ar tiem saistìtos sagaidāmos rezultātus (sk. 2.2. tabulu).

Latvijas Republikas ministrijas san̦ēma palīdzību praktisko iekšējo auditu veikšanā - tika veikti auditi Phare eksperta vadībā katrā ministrijā. Ar šiem paveiktajiem uzdevumiem tika sākts ceḷ̌s uz mūsdienīgu auditu sistēmu Latvijas valsts tiešajā pārvaldē, kura uzdevums nav sniegt autorizācijas vai finanšu kontroli, bet noteikt, vai šāda veida kontroles pastāv - riski tiek identificēti, kontroles mehānismi ir noteikti un citi izpilda kontroles mehānismus.

R. Šulca (2010) ${ }^{91}$ un G. Vērdiña (2012) ${ }^{92}$ Latvijas IA attīstỉbu līdzīgi ir iedalïjušas trīs posmos (sk. 2.3. tabulu).

${ }_{91}^{1}$ Šulca R. (2010) Latvijas pašvaldìbu iekšèjā audita sistēmas attīstības iespējas. Pētījuma kopsavilkums. Jelgava, 131. lpp.

${ }^{92}$ Vērdin̦a G. (2012) Iekšêjās kontroles sistēmas pilnveidošanas iespējas studiju programmas īstenošanas procesos. Promocijas darbs vadībzinātnes doktora zinātniskā grāda iegūšanai izglīīibas vadības apakšnozarē. Rīga: LU PPMF, 252. lpp. 
2.3. tabula. IA vēsturiskās attīstības posmi pētnieku skatījumā 2010. un 2012. gadā Latvijas valsts tiešajā pārvaldē

\begin{tabular}{|l|l|l|}
\hline \multicolumn{1}{|c|}{ Posms, gadi } & \multicolumn{1}{|c|}{ Šulca R. (2010) } & \multicolumn{1}{c|}{ Vērdiña G. (2012) } \\
\hline 1. posms. 1999-2005 & $\begin{array}{l}\text { IA tiesiskās un metodiskās bāzes } \\
\text { izveide }\end{array}$ & $\begin{array}{l}\text { Sagatavošanās posms iestājai ES: } \\
\text { tiesiskās un metodiskās bāzes izveide }\end{array}$ \\
\hline 2. posms. 2006-2009 & IA darbības pilnveidošana & $\begin{array}{l}\text { IA darbības īstenošana un } \\
\text { pilnveidošana }\end{array}$ \\
\hline 3. posms. 2010-2012 & $\begin{array}{l}\text { IA jaunu darbības virzienu izstrāde } \\
\text { (2010) }\end{array}$ & $\begin{array}{l}\text { IA pilnveides un darbības attīstība } \\
\text { (2010-2011) }\end{array}$ \\
\hline
\end{tabular}

Avots: autores veidota tabula, pamatojoties uz R. Šulca (2010) un G. Vērdiṇa (2012).

Abi iepriekš minētie pètījumi ietver līdzīgus IA attīstības posmus, kam autore dạ̦ēji piekrìt. Tomēr, ņemot vērā faktu, ka kopš 2011. gada IA vēsturiskajā attīstībā ir iezīmējušās jaunas pārmaiņas, autore veidojusi savu sadalījumu (detalizēts normatīvo aktu apkopojums dots 1. pielikumā). Laika periodā no 1999. gada līdz 2013. gadam IA pieejas ir mainījušās līdz ar normatīvo aktu grozijjumiem. Iekšèjā audita metodikas attīstība Latvijas valsts tiešajā pārvaldē atbilstoši normatīvo aktu izmaiņām, pēc autores domām, ir iedalāma četros posmos:

1) IA ieviešana Latvijas valsts tiešajā pārvaldē (1999-2002);

2) Pārejas periods - statusu maiña - ES prasību izpilde (2003-2009);

3) Standartu prasību iekḷaušana normatīvajos aktos (2010-2012);

4) IA sistēmas, tiesiskā regulējuma pilnveidošana (no 2013. gada).

\section{IA ieviešana Latvijas valsts tiešajā pārvaldē (1999-2002)}

Pirmais Latvijā pieņemtais IA regulējošais normatīvais akts ir MK 05.10.1999. noteikumi Nr. 342 "Noteikumi par iekšējo auditu", kas attiecībā uz IA metodiku noteica, ka IA tiek veikts, lai sniegtu atbildīgajai institūcijai vērtējumu par IKS efektivitāti un atbilstību iestādes izvirzìto mērķu sasniegšanā; iesniegtās finanšu, uzskaites un citas informācijas ticamību un pilnību; iestādes struktūrvienību darbības atbilstību normatīvajiem aktiem, iestādes izstrādātajai stratēgijai, politikai, apstiprinātajiem rīcỉbas plāniem, noteiktajām funkcijām un personāla politikai; efektīvu un ekonomisku resursu izmantošanu, drošu kontroli un aizsardzību pret zaudējumiem.

Organizējot darbu atbilstoši IA standartiem, FM bija atbildīga par metodisko materiālu, ieteikumu IA rokasgrāmatas izstrādi, tāpat IA padomei bija jāizskata un jāsniedz viedoklis par grozijumiem Standartos un IA rokasgrāmatā. 2000. gadā FM izstrādātie metodiskie ieteikumi "Iekšèjā audita rokasgrāmata”, kas regulāri tika papildināta, bija ieteikumi ministriju un valsts pārvaldes iestāžu IA struktūrvienībām, kas savu IA metodiku (IAS darba organizācijas, 
plānu izstrādes, audita veikšanas dokumentēšanas, audita darba dokumentu sagatavošanas un audita lietas kārtošanas, kā arī pārskatu sagatavošanas pamatnostādnes) veidoja, pamatojoties uz šo dokumentu.

\section{3.-2009. gada pārejas periods - statusu maiṇa - ES prasību izpilde}

2002. gada nogalē tika pieņemts Iekšêjā audita likums, kas aizstāja MK noteikumus Nr. 342 "Noteikumi par iekšējo auditu", savukārt 2003. gada vasarā tika pieņemti MK noteikumi, kas noteica IA veikšanas kārtību, IA padomes nolikumu, sertifikācijas kārtību, IKS izveidošanas prasības, salīdzinošo pārbaužu veikšanas kārtību, IA metodiku un atsevišķu kārtību ES finansēto projektu IA. Audita posmu skaits atbilstoši MK 2010. gada 28. septembra noteikumiem "Iekšêjā audita veikšanas kārtība" ir salīdzinoši mazāks, taču pēc būtības tie ietver visus svarīgākos elementus (2.2. attēls): audita plānošana; pārbaudes un rezultātu novērtējums; ziņojuma un ieteikumu ieviešanas grafika saskaņošana; audita slēgšana; ieteikumu ieviešana un uzraudzība; audita lietas slēgšana. Kvalitatīvi veikta audita pamats ir secīgu IA veikšanas posmu izpilde, kas veidots, pamatojoties uz sākotnējo FM ieteikumu - "Iekšējā audita rokasgrāmatu"- metodiku, kas, pēc autores domām, kopumā ir detalizēta, raksturojot katru audita veikšanas posmu.

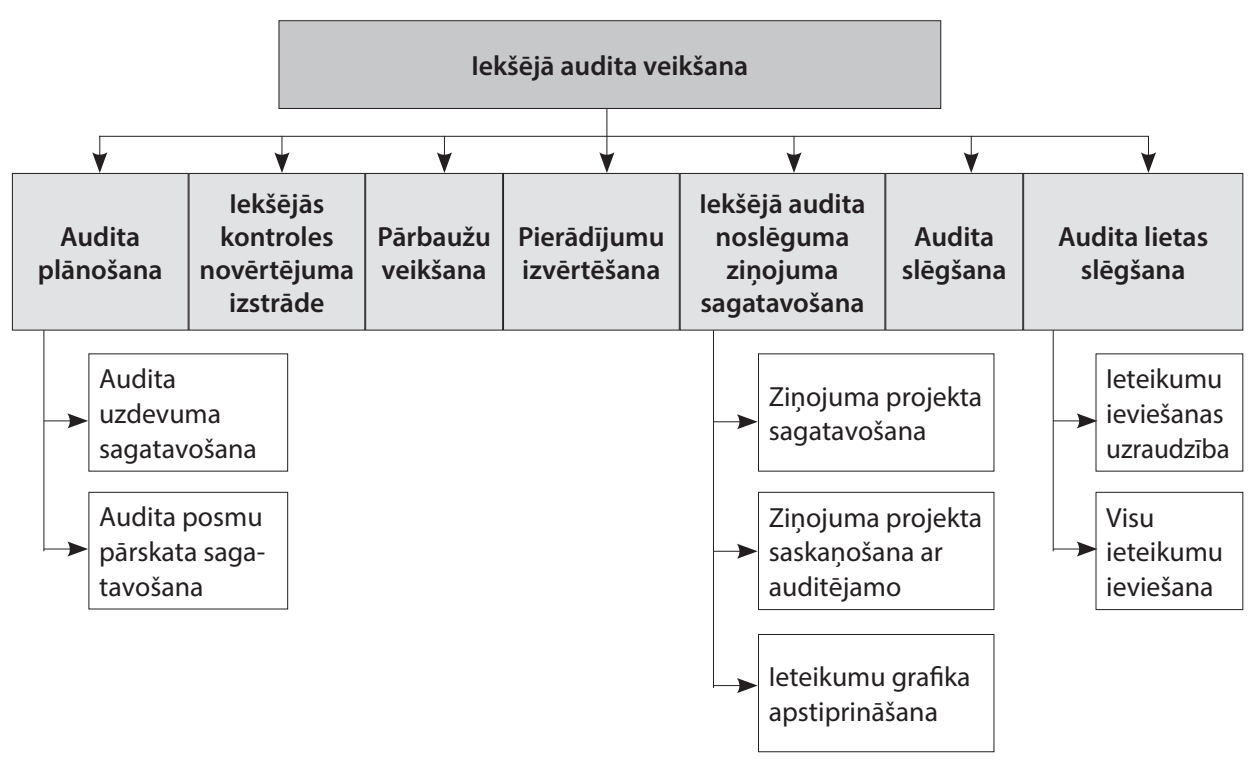

2.2. attēls. lekšējā audita veikšanas posmi Latvijas valsts tiešajā pārvaldē

Avots: autores veidota shēma, pamatojoties un Latvijas Republikas normatīvajiem aktiem. 


\section{Starptautisko standartu prasību iekḷaušana normatīvajos aktos 2010.-2012. gadā}

Ar 2010. gada izmain̦ām normativvajos aktos IA jomā valsts pārvalde (FM) “ir centusies iet kopsolī ar laiku” un nopietni domāt par divām profesijai būtiskām lietām:

1) kā paaugstināt iekšèjo auditoru darba kvalitāti, līdz ar to arī uzticību darba rezultātiem un profesijai;

2) kā samazināt dokumentu gatavošanai patērēto laiku un vairāk domāt par pievienotās vērtības sniegšanu iestādei un tās vadỉbai.

Jāatzīmē, ka krīzes gados neviena cita valsts pārvaldes funkcija nav tik l̦oti analizēta un vērtēta kā IA, kas ir daḷeji saprotams, jo, meklējot taupīšanas iespējas, prioritātes tiek dotas iestādes pamatfunkcijām. Tādējādi tika nolemts veikt uzlabojumus divos virzienos:

1) pilnveidot iestāžu vadītāju zināšanas un kompetenci iekšējās kontroles un iekšējā audita jautājumos;

2) pilnveidot IA funkcijas ${ }^{93}$.

MK 2010. gada 28. septembra noteikumu Nr. 918 "Iekšējā audita veikšanas kārtība” būtiskākie grozījumi skar IA plānu izstrādes procesu: ilgtermiņa attīstības plāns apvienots ar stratēǵisko plānu, ir mazāk reglamentēta plānu forma, vienoti plānu izstrādes principi, lai atvieglotu novērtēšanu un salīdzināšanu. Rezultātu salīdzināšanas nolūkā noteikumos ir definētas vienotas atbalsta funkciju sistēmas (stratēgiskā un darba plānošana, riska un kvalitātes vadỉba, personāla vadība, finanšu vadība, iekšējā un ārēja komunikācija, darbības nodrošināšana, iepirkums, uzskaite un atskaites, juridiskais atbalsts, IT vadība). Lai labāk izprastu riska līmeni valsts pārvaldē kopumā, ir noteikti vienoti riska faktori un to novērtēšanas kritēriji, kā arī pēc kopīgiem principiem noteikts sistēmas auditēšanas biežums piecu gadu periodā. Sistēmu auditēšanas biežuma noteikšanai izvirzīti šādi riska faktori: iespējamie finansiālie zaudējumi, pašu vai ārējo auditoru konstatētās problēmas, sistēmas nozīmīgums mērḳu sasniegšanā, notikusī reorganizācija vai izmaiņas, korupcijas iespējamība, sekmīgai darbībai nepieciešamā darbinieku kompetences pakāpe, iespējamie draudi iestādes reputācijai un sarežǵītība. Turklāt paredzēta uzlabota gada plāna forma - gada plānā papildus jānorāda audita nosaukums, kas l̦auj izprast, vai tiks auditēta sistēma vai tās daḷa. Cits noteikumu jauninājums ir vienkāršota ikgadējā pārskata forma, kam pēc auditoru vēlmēm paredzēta papildu informācija. Mazāk

\footnotetext{
${ }^{93}$ Lasmane N. (2010) Iekšējais audits valsts pārvaldē - izmainas normatīvajos aktos. Bilance, Nr. 19 (247), 14.-15. lpp.
} 
reglamentēts pats audita process, bet ir noteikti obligātie posmi: audita plānošana, pārbaužu veikšana un rezultātu novērtēšana, ziņojuma sagatavošana un ieteikumu saskaņošana, audita slēgšana, ieteikumu ieviešanas uzraudzība un audita lietas slēgšana. Līdzīgi atvieglots reglamentējums audita procesa dokumentācijai - katra struktūrvienība to var noteikt atbilstoši savai specifikai, pieredzei, IT resursu pieejamībai u. tml. Minētajos MK noteikumos tiek saglabāts pamatprincips: audita gaitai no audita mērķu noteikšanas līdz secinājumiem un ieteikumiem jābūt izsekojamai. Būtiska ir darba kvalitātes uzraudzība un izvērtēšana, kas tiek veikta trijos veidos: nepārtraukta uzraudzība, ko realizē pašas IAS ikdienas darba gaitā; periodiska pašnovērtēšanās, kuru organizē IAS vadītājs, parasti reizi gadā; un periodiska ārējā novērtēšana, kuru īsteno ārējie eksperti, parasti ik pa pieciem gadiem. Noteikumos atrodami arī kopèjie IA kvalitātes novērtēšanas kritēriji:

1) personāla kvalifikācija;

2) audita procesa efektivitāte;

3) pievienotā vērtība iestādei.

Būtiski pārstrādāta valsts pārvaldes iekšējo auditoru sertifikācijas kārtība, to maksimāli tuvinot starptautiskajai auditoru sertifikācijas praksei: divu līmeņu sertifikāts aizstāts ar vienu, pretendentu rakstiskais darbs un prezentēšana nomainīta ar pārbaudījumu testu, pretendentam prasot divu gadu praktisko pieredzi.

2011. gadā valsts pārvaldē izstrādātas, pēc tam aktualizētas un papildinātas "Iekšèjā audita veikšanas vadlīnijas" " IA veikšanas vadlīniju pirmajā daḷā ietvertas sadaḷas, kas apkopo informāciju par IA sistēmas izveidošanu, struktūrvienību plānu izstrādi, kārtību, kādā veicams audits; IAS plānu izstrādi: pašnovērtējums, klientu apmierinātības novērtējums, attīstības prioritāšu un pasākumu noteikšana, laiks un regularitāte; IAS sasniedzamo rezultātu noteikšana; IAS resursi; iekšējā audita vides noteikšana, aktualizācija, sistēmu apraksta sagatavošana, riska novērtējums un prioritāro sistēmu noteikšana, IA stratēǵiju noteikšana, resursu saskaņošana un gada plānu izstrāde. Pielikumos ietverti iekšèjā auditora darbam svarīgie paraugi: vadlīnijas; rīkojumu, reglamentu, auditējamo sistēmu apraksti; auditējamās sistēmas "Finanšu vadỉba" apakšsistēmas "Grāmatvedỉbas uzskaites optimizācija un izpildes kontrole" audita vide un audita veikšanas apraksts; audita vides veidlapas; darba izpildes un kvalitātes rādītāji; darbam patērēto dienu skaita sadalījums; IAS pašnovērtējuma anketa, kā arī klienta apmierinātības novērtēšanas anketa.

\footnotetext{
94 Finanšu ministrija (2011) Iekšējā audita veikšanas vadlīnijas. Nepublicēta informācija.
} 
IA veikšanas vadlīniju otrajā dal̦ā ietverta skaidrojoša informācija ne tikai par audita plānošanu (posmu plānošana, sistēmas analīze, darba uzdevums, programmas izstrāde, riski un kontroles), bet arī par auditu veidiem (lietderības audits, vertikālais vai horizontālais audits, atbilstības audits, finanšu audits, krāpšanās audits, funkciju audits, IT audits, kvalitātes audits). Pielikumos ietverti vairāki dokumentu paraugi: audita posmu izpildes grafiks; vēstule par audita uzsākšanu; plūsmu shēma sistēmai "Personāla vadība un iespējamie novērtēšanas kritēriji personālvadības sistēmai"; audita uzdevuma darba plāns; audita programma - risku saraksts un sākotnējās kontroles novērtējums; izmaksu samazinājuma iespēju izvērtēšanas pārbaudes lapa; papildu informācija par krāpšanu.

IA veikšanas vadlīniju trešajā daḷā iekḷauti skaidrojumi par izlasi (paraugu atlases metodes, izlases metodes, izlases dokumentēšana), par pārbaudēm un rezultātu novērtējumu (pārbaudes un pārbaužu metodes), darba dokumentiem, kontroles novērtējumu un ziņošanu (ziņojuma un ieteikumu ieviešanas grafika projekts, saskaņošana un tās dokumentēšana; ziņojuma un grafika izstrāde; auditējamā viedokḷa iekḷaušana; rīcỉba gadījumos, ja ziņojums satur būtiskas neprecizitātes; ieteikumu ieviešanas uzraudzība; darba izpildes un kvalitātes uzraudzība; IAS gada pārskats; konsultāciju sniegšana; dažādi pielikumi ar dokumentu paraugiem; standartu skaidrojumi). Vadlīnijas kopumā ietver daudz dažādus piemērus, kas iekšējam auditoram palīdz veikt kvalitatīvus auditus atbilstoši LR normatīvo aktu prasībām, kā arī ievērojot starptautisko standartu nosacījumus.

\section{Kopš 2013. gada - iekšējā audita sistēmas, tiesiskā regulējuma pilnveidošana}

12.12.2012. pieņemtais Iekšèjā audita likums, kam sekoja MK 30.04.2013. noteikumi Nr. 238 "Iekšējo auditoru sertifikācijas kārtība" un MK 09.07.2013. noteikumi Nr. 385 "Iekšējā audita veikšanas un novērtēšanas kārtība" ir uz 2017. gada sākumu spēkā esoši un grozījumus neiekḷaujoši normatīvie dokumenti. Iekšèjā audita likuma anotācijāa ${ }^{95} \mathrm{FM}$ skaidroja, ka pamatā likumā tiks atstāts spēkā esošais tiesiskais regulējums, tomēr tas tiks precizēts vai papildināts. Lai nodrošinātu plašākas un pilnvērtīgākas auditoru zināšanas un kompetentākus

\footnotetext{
${ }^{95}$ Iekšèjā audita likuma anotācija. MK 24.07.2012. vēstule Nr. 90/TA-1504. Pieejams: http://titania. saeima.lv/LIVS11/SaeimaLIVS11.nsf/0/81316E6CBC37664DC2257A4600429842?OpenDocument\#b [skatîts 25.02.2017].
} 
auditorus, likumā noteikts, ka IAS vadītājam pienākumu pildīšanai ir nepieciešams normatīvajos aktos noteiktā kārtībā iegūts valsts pārvaldes iekšèjā auditora sertifikāts vai biedrības "Iekšējo auditoru institūts" atzìts iekšèjā auditora profesionalitāti apliecinošs sertifikāts.

Ar izmaiņām normatīvajos aktos noteikta iespējamā rīcība darba izpildes un kvalitātes uzraudzībai visos IA posmos gadỉjumā, ja ministrijā vai iestādē IA funkciju īsteno viens iekšējais auditors. Šādā gadījumā IA darba izpildes un kvalitātes uzraudzību var veikt citas institūcijas IAS. Tāpat ar izmaiņām par IAS darbibu atbilstoši noteiktajam darba apjomam IAS sniedz viedokli par IKS: riska vadības pasākumiem, kontroles pasākumiem un pārvaldības pasākumiem.

Ar normatīvo aktu izmaiņām arī noteikts, ka plānotie IA ir tādi IKS novērtējumi, kuri izriet no IAS gada plāna. Ja pārskata gada laikā jāsniedz neplānots IA, tad IAS iesniedz vadības apstiprināšanai aktualizētu IA gada plānu. Regulējumā precizēti likumā noteiktie delegeējumi, nosakot, ka FM ir atbildīga par IA politikas izstrādi.

Apkopojot IA normatīvo aktu prasības kopš 1999. gada (sk. 1. pielikumu), autore secina: katra nākamā Iekšêjā audita likuma versija un MK noteikumi, kā arī FM izstrādātie metodiskie ieteikumi - gan Iekšèjā audita rokasgrāmata no 2000. gada līdz 2007. gadam, gan MK instrukcija Nr. 8 "Iekšèjā audita metodika" no 27.04.2007. līdz 01.10.2010., gan MK noteikumi Nr. 918 "Iekšejā audita veikšanas kārtība" no 07.10.2010. līdz 01.06.2013., gan pašlaik spēkā esošais Iekšèjā audita likums un saistošā MK kārtība, tāpat IA veikšanas vadlīnijas pēc būtības ietver vairākus nemainīgus aspektus. Visi normatīvie akti ir pilnveidoti, pamatojoties uz pieredzi un labo praksi. Autore secina, ka normatīvo aktu izmaiņas ietekmējušas vairākus IA veikšanas posmus:

1) audita sistēmas noteikšanu;

2) IAS plānu izstrādi;

3) audita plānošanu;

4) auditu veidus;

5) darba dokumentus;

6) auditoru sertifikācijas kārtību, procesus un saturu vairāk pietuvinot starptautiskajai sertifikācijai.

Kopumā autore secina, ka IA normatīvie akti un metodikas laika periodā kopš 1999. gada ir pilnveidotas atbilstoši EK prasībām un Standartu izmaiņām, kā arī saskaṇā ar Latvijas Republikas tiesiskā regulējuma izmaiņām, taču nenoliedzami Latvijas politisko spēku ietekme jūtama arī IA ieviešanas jomā, par ko autore ir pārliecinājusies pētījumā par pašvaldību iekšējā audita ieviešanas jautājumiem (2.2. nodal̦a). 


\subsection{3. lekšējā audita loma Latvijas valsts tiešajā pārvaldē}

MK apstiprinātais "Pasākumu plāns Iekšejāā audita sistēmas pilnveidošanai" (apstiprināts ar MK 24.02.2010. rīkojumu Nr. 114) nosaka to, ka valsts pārvaldē kopumā nepieciešama lielāka vadības uzmanība IKS stiprināšanai, ko iespējams paveikt, novēršot iespējamos normatīvo aktu pārkāpumus un resursu nelietderīgu, l̦aunprātīgu vai kḷūdainu izmantošanu. Vienlaikus IKS uzlabošanai ir nepieciešama gan institūcijas vadības funkcijas uzlabošana, gan IA sistēmas stiprināšana. Ar MK rīkojumu katru gadu tiek noteiktas kopējās valsts pārvaldē auditējamās prioritātes (sk. 2. pielikumu). Autoresprāt, galvenās prioritātes 2013.-2018. gadā formulējamas šādi:

- 2013. gadā - FM un VARAM veikt auditu "Pašvaldību finanšu pārskatu sagatavošanas nenodokḷ ieņēmumu un ilgtermiṇa ieguldijumu uzskaites jomas uzraudzības un pašvaldībām piederošo kapitālsabiedrību pārraudzības IKS darbība";

- 2014. gadā - novērtēt ministrijās un iestādēs izveidotās likumu un MK noteikumu izstrādes un virzības IKS, novērtējot normatīvo aktu izstrādes savlaicīgumu un atbilstību prasībām, sabiedrības līdzdalības nodrošināšanu, izstrādes ekonomisko efektivitāti, kā arī veikt līdzīgu procesu auditus attiecīgā resora iestādēs;

- 2015. gadā - IT vadības sistēmas IA, novērtējot informācijas un komunikācijas tehnolog̣iju pārvaldības organizēšanu, nepieciešamo resursu plānošanu, uzskaiti, sagādi, ieviešanu, izmantošanu, uzturēšanu, koplietošanu, optimizēšanu un valsts informācijas sistēmas drošỉbas pasākumu izveidi;

- 2016. gadā - IT vadības sistēmas IA, novērtējot IKS informācijas tehnoloǵiju projektu vadỉbā;

- 2017. gadā - valsts pārvaldes pakalpojumu IA, novērtējot pakalpojumu kvalitāti, organizāciju un pieejamību privātpersonām (vienas pieturas ağentūras, e-pakalpojumi);

- 2018. gadā - novērtēt, vai ieviestie IKS elementi sekmē procesu efektīvāku norisi un veicina orientāciju uz sasniedzamo rezultātu; izlases veidā veikt līdzīgu procesu IA attiecīgā resora iestādēs; nodrošināt savstarpēju sadarbïbu un pēc iespējas veidot starpresoru IA komandas, auditējot tādu politiku, kura tiek plānota, īstenota un uzraudzīta mijiedarbībā ar citiem resoriem;

- 2019. gadā - novērtēt, vai ieviestie IKS elementi sekmē procesu efektīvāku norisi un orientāciju uz sasniedzamo rezultātu; izlases veidā atbilstoši riska novērtējumam turpināt vienlaikus veikt līdzīgu procesu IA attiecīgā resora iestādēs; nodrošināt savstarpēju sadarbỉbu un pēc 


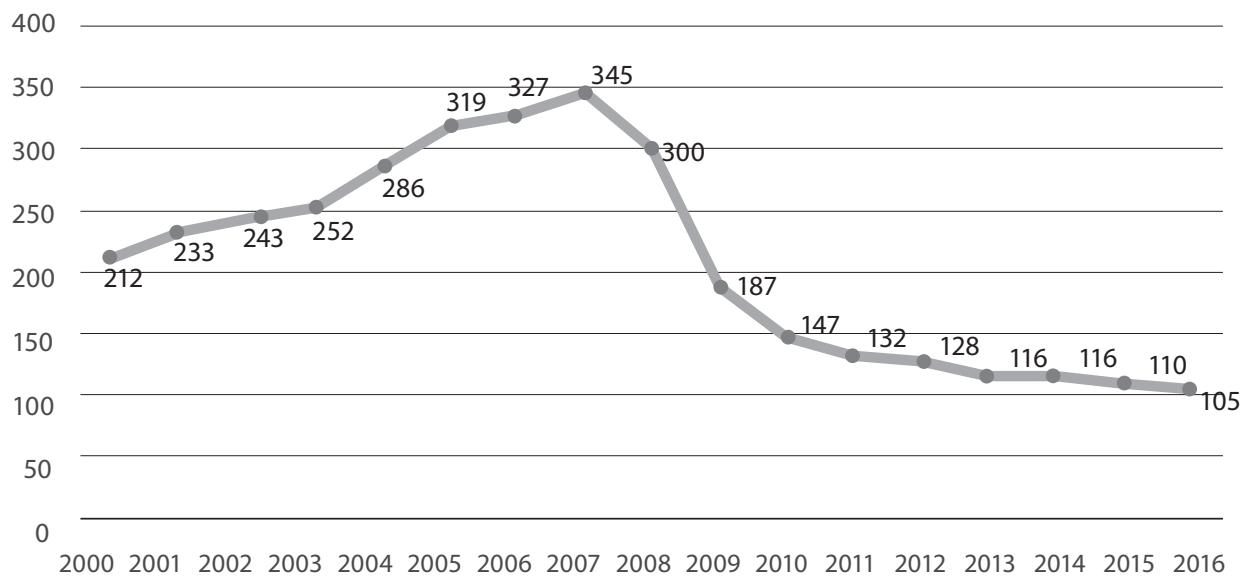

\section{3. attēls. Kopējais iekšējo auditoru štata vietu skaits Latvijas Republikas ministrijās un iestādēs (2000-2016)}

Avots: autores veidots grafiks, pamatojoties uz FM informatīvajiem ziṇojumiem (1999-2016).

iespējas veidot starpresoru IA komandas, auditējot tādu politiku, kas tiek plānota, īstenota un uzraudzīta mijiedarbībā ar citiem resoriem. ${ }^{96}$ Autore, apkopojot FM informatīvos ziņojumus par IA darbību ministrijās un iestādēs par laika periodu no 1999. līdz 2016. gadam, ir izstrādājusi secinājumus par dažiem IA darbu raksturojošiem rādītāiiem. FM informatīvo ziņojumu mērḳis ir informēt MK par IAS darbību ministrijās un iestādēs, iekḷaujot viedokli par IKS ministrijās un iestādēs atbilstoši Iekšèja audita likuma prasībām. Saskaṇā ar pēdējo FM informatīvo ziṇojumu par IA darbïbu ministrijās un iestādēs 2016. gadā 13 ministrijās, septiņās padotībā esošajās iestādēs, Valsts kancelejā un Sabiedrības integrācijas fondā (no 192 iestādēm kopumā) darbojās 23 IA struktūrvienības (2015. gadā - 24) ar 105 iekšējiem auditoriem, no kuriem deviņi procenti bija vakances vai darbinieki atradās prombūtnē.

Ziņojumā norādīts, ka Korupcijas novēršanas un apkarošanas biroja sniegtā informācija par IA "nav izsekojama, nav skaidra darba izpildes un kvalitātes rādītāju aprēkināšanas metode, sniegta neprecīza informācija par auditējamo sistēmu pārklājumu iestādē". ${ }^{97}$

\footnotetext{
${ }^{96}$ Par kopējām valsts pārvaldē auditējamām prioritātēm 2011.-2019. gadā. MK rīkojumi. Pieejams: http://www.fm.gov.lv/lv/sadalas/iekseja_audita_politika/normativie_akti/ [skatīts 14.03.2019.]

${ }^{97}$ Pārskats par IA sistēmas darbību valsts pārvaldē 2016. gadā. Pieejams: http://www.fm.gov.lv/lv/ sadalas/iekseja_audita_politika/parskati/2016_gada/55165-2016gada [skatīts 25.09.2017.]
} 
Laika gaitā IA metodika un pieejas valsts pārvaldē ir mainījušās. 2009. gadā tika uzsākta IA centralizācija līdz ministriju līmenim, tāpēc likvidēti vairāki desmiti struktūrvienību visā valsts pārvaldē. Kopumā iekšējo auditoru skaita dinamika (2.3. attēls) parāda, kā kopējās valsts ekonomiskās sistēmas ietekmē ir krasi mainījies iekšējo auditoru skaits. Pēc FM apkopotajiem datiem redzams, ka 2007. gadā bija lielākais iekšêjo auditoru štata vietu skaits, un tas kopš IA ieviešanas valsts pārvaldē ir palielinājies par 63\%, bet, sākot ar 2008. gadu, kad vērojams samazinājums par 13\%, salīdzinot ar iepriekšējo gadu, iekšējo auditoru skaits sāka strauji samazināties. Tas izskaidrojams ar kopējo ekonomisko situāciju valstī, kad publiskajā sektorā tika samazinātas štata vietas, bet IA joma tika uzskatīta par to, kuru daudzās padotības iestādēs var likvidēt. 2016. gada dati liecina, ka auditoru skaits, salīdzinot datus ar 2000. gadu, ir samazinājies vairāk nekā par 50\%.

Autore uzskata, ka auditoru skaita samazinājuma negatīvā ietekme skar gan IA plānu savlaicīgu izpildi, gan pašu iekšējo auditu kā IKS sakārtošanas instrumentu.

Atbilstoši 2010. gada grozījumiem IA normatīvajos aktos ministriju un iestāžu IAS savos gada pārskatos ir ieḳ̣āvušas informāciju par vidējo iekšējo auditoru darba stāžu (2.4. attēls). Analizējot pēdējos piecus gadus, vidējais valsts pārvaldes IA darbinieku darba stāžs pa gadiem mainās no viena gada līdz gandrīz vidēji 20 gadiem darba pieredzes. Pozitīva tendence vērojama pēdējos trijos gados, kad mazākā vidējā pieredze ir lielāka par vienu gadu, taču, ņemot vērā, ka šis rādītājs FM publicētajos pārskatos ir vidējais darba pieredzes laiks, saprotams, ka joprojām valsts pārvaldē ir auditori ar nelielu pieredzi, turklāt to skaits, sākot ar 2013. gadu, ievērojami samazinās.

2016. gadā ilgākais iekšêjā auditora darba stāžs valsts tiešajā pārvaldē, salīdzinot ar 2013. gadu, pieauga par trim gadiem, taču îsākais stāžs tikai par vienu gadu (2.4. attēls). Kā liecina analīzes dati, visos gados Neatliekamās medicīniskās palīdzības dienesta IAS auditoriem bija īsākais darba stāžs, savukārt iekšējie auditori ar ilgāko darba pieredzi pēdējos pētāmajos gados strādā Ârlietu ministrijā.

Saistībā ar informatīvo ziņojumu par IA darbību ministrijās un iestādēs 2016. gadā IA padome savā 2017. gada atzinumā aicināja kritiski izvērtēt, vai esošā audita kapacitāte, kompetence un efektivitāte ministriju resoros ir pietiekama, tāpat padome vērsa uzmanību uz atalgojuma līmeņa pārskatîšanu, uzskatot, ka iekšèjā auditora atalgojumam jābūt līdzvērtīgam institūcijas pamatdarbības funkciju veicējiem ${ }^{98}$.

\footnotetext{
${ }_{98}$ Pārskats par iekšējā audita sistēmas darbību valsts pārvaldē 2016. gadā. Pieejams: http://www.fm.gov. lv/lv/sadalas/iekseja_audita_politika/parskati/2016_gada/55165-2016gada [skatitts 25.09.2017.]
} 


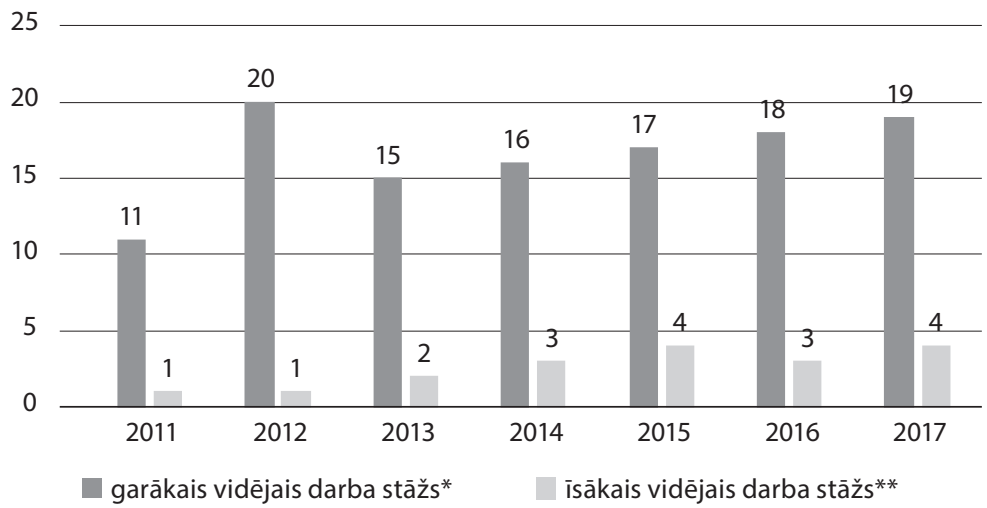

\section{4. attēls. Latvijas Republikas valsts tiešās pārvaldes IAS darbinieku vidējais darba stāžs gados (2011-2017)}

Avots: autores veidota diagramma, pamatojoties uz FM informatīvajiem zinojumiem.

* 2011. gadā - Valsts kancelejā, 2012. gadā - Korupcijas novēršanas un apkarošanas birojā, 2013.-2017. gadā Ārlietu ministrijā.

** 2011.-2017. gadā - Neatliekamās medicīniskās palīdzības dienestā.

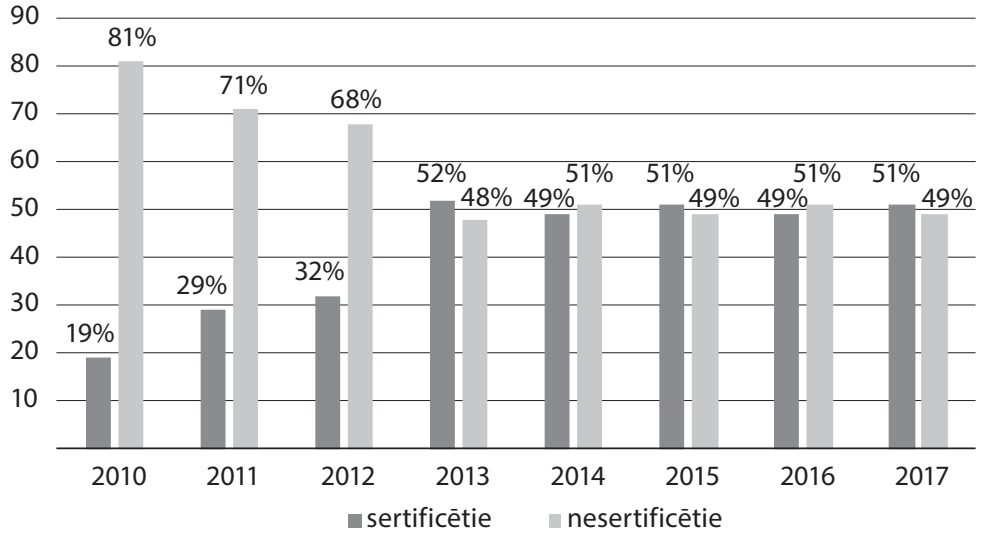

\section{5. attēls. Latvijas Republikas sertificēto iekšējo auditoru ippatsvars valsts tiešajā pārvaldē (2010-2017, \%)}

Avots: autores veidota diagramma, pamatojoties uz FM informatīvajiem ziṇojumiem.

Lai gan pastāv darbinieku mainība, strādājošie ar lielāko darba pieredzi turpina darbu valsts tiešajā pārvaldē, tādējādi nodrošinot jauno darbinieku praktisko apmācību. Pakārtots lielums auditoru darba pieredzei ir iekšējo auditoru sertifikācija, kas nosaka iekšêjā auditora kompetences līmeni. Sākot ar 2011. gadu, sertificēšanās sistēma regulējošos normatīvos aktos ir krasi mainīta, taču sertificēto auditoru skaits turpina palielināties līdz 2013. gadam (2.5. attēls), 
bet pēc tam tas ir bijis mainīgs - 2014. gadā samazinās par trim procentpunktiem, savukārt 2015. gadā atkal vērojams divu procentpunktu palielinājums salīdzinājumā ar iepriekšējo gadu.

Valsts pārvaldē sertificēto auditoru skaits laika periodā no 2010. līdz 2013. gadam palielinājās, taču 2014. gadā bija vērojams samazinājums, kas saistīts ar kopējo auditoru skaita samazinājumu vispār. 2016. gadā šie rādìtāji atgriezās 2014. gada rādītāju līmenī, kad sertificēto auditoru skaits bija par diviem procentpunktiem mazāks nekā nesertificēto iekšējo auditoru skaits, savukārt 2017. gada dati liecina par stabilitāti šajā jomā. Sertifikācijas motivācijas trūkumam ir savs izskaidrojums, jo Iekšējā audita likums nosaka obligātu sertifikāciju tikai struktūrvienības vadītājiem, bet pārējiem iekšējiem auditoriem sertifikācija ir brīvprātīga. Autore uzskata, ka iekšèjā auditora sertifikātam vajadzētu būt vienam no obligātajiem dokumentiem, pretendējot uz iekšèjā auditora amatu, it îpaši tāpēc, ka Latvijā nav iespējams iegūt auditora vai iekšèjā auditora kvalifikāciju kādā no izglìtības iestādēm.

Atbilstoši FM ziņojumam IA procesa efektivitāti raksturo gada plāna izpilde, noslēgto auditu skaits, ziṇojumu skaits un to savlaicīgums, kā arī IA funkcijai patērētais laiks. 2015. gadā iekšêjie auditori noslēguši 143 auditus, kuru iesniegšana vidēji kavēta $31 \%$ gadỉjumu. Ar IA saistīto dienu skaits 2015. gadā ir 81\% no visām darbinieka darba dienām atbilstoši darba laika uzskaites datiem

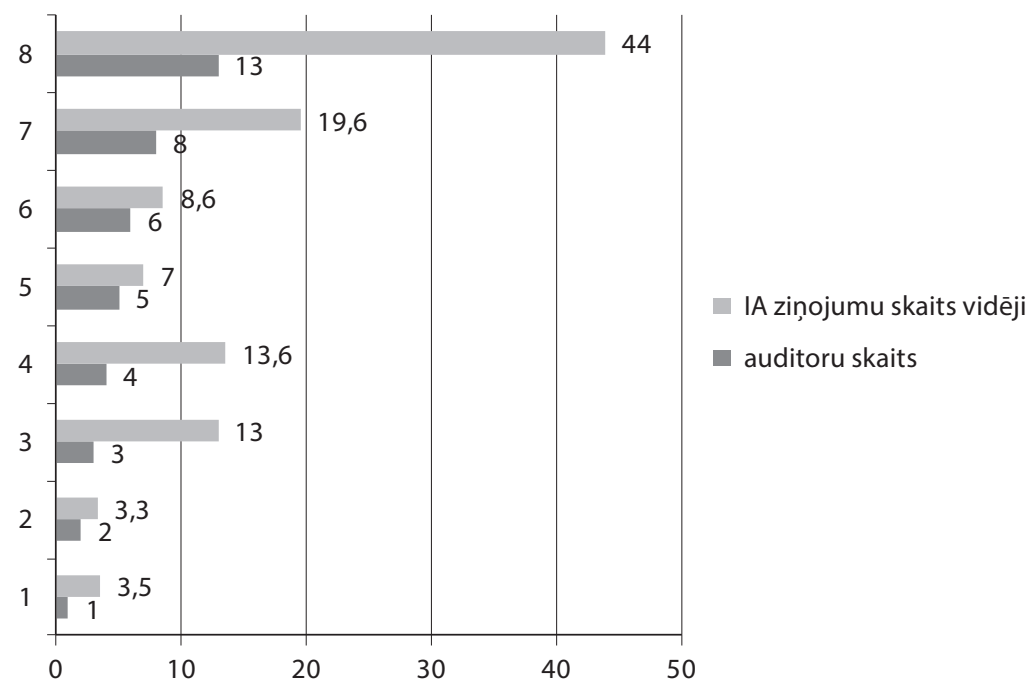

2.6. attēls. Latvijas Republikas iekšējo auditoru skaita un vidējā ziṇojumu skaita sakarības 2014. gadā

Avots: autores veidota diagramma, pamatojoties uz FM informatīvajiem zịnojumiem. 
(2014. gadā - 82\%), savukārt IA gada plāns valsts pārvaldē 2015. gadā bija izpildìts par 70\% (2014. gadā - 89\%). Kopumā auditori sagatavojuši 220 ziṇojumus, ziņojumu skaita loǵisks pieaugums ir saistīts ar iekšējo auditoru skaita izmaiņām, taču, kā rāda dati, tas ne vienmēr tiek izpildīts (2.6. attēls). 2014. gadā iestādēs un ministrijās vidēji trīs IA ziṇojumus sagatavoja gan viens auditors, gan divu auditoru komanda. Šajā ziņā jān,em vērā vairāki faktori, kas ietekmē ziņojumu skaitu - auditoru pieredze un kompetence, daudzi personīgo īpašìbu faktori, piemēram, darba spējas, darba temps u. c., kā arī audita veidi un apjoms.

Lai noskaidrotu Latvijas IA speciālistu viedokḷus par IA attīstîbu un nozīmi, autore veica vairākas aptaujas. Pirmā aptauja tika veikta laika periodā no 2010. gada 15. decembra līdz 2011. gada 29. janvārim. Tā tika organizèta elektroniski, jautājumus izsūtot uz e-pastu Latvijas Zvērinātu revidentu asociācijai un Iekšējo auditoru institūtam, tāpat pašvaldību iekšējiem auditoriem, zvērinātiem revidentiem, Latvijas augstāko mācību iestāžu mācībspēkiem un valsts pārvaldes iekšējiem auditoriem. Aptaujas rezultātā tika apkopotas 150 pilnīgi vai dalęji aizpildītas anketas. Ar vienkāršas gadījuma izlases jeb īsti nejaušās izlases palīdzību tika veikta vienību individuāla atlase bez iepriekšējas grupēšanas un datu analīzē tika izmantotas 70 pilnībā aizpildìtas anketas.

\section{4. tabula. 2010., 2011. gadā veiktās aptaujas respondentu iedalijjums}

\begin{tabular}{|l|c|c|}
\hline \multicolumn{1}{|c|}{ Respondentu grupa } & $\begin{array}{c}\text { Generālkopas lielums uz } \\
\mathbf{0 1 . 0 2 . 2 0 1 1 .}\end{array}$ & $\begin{array}{c}\text { Aptaujas izlases apjoms } \\
\text { (skaits un \% no ǵenerālkopas) }\end{array}$ \\
\hline $\begin{array}{l}\text { lekšējie auditori (IAl biedri un valsts } \\
\text { pārvaldes iekšējie auditori, pieņemot, ka } \\
\text { 30\% ir valsts pārvaldes iekšējie auditori) }\end{array}$ & 236 & $32(13,6 \%)$ \\
\hline Zvērināti revidenti & 157 & $16(10,2 \%)$ \\
\hline Zvērinātu revidentu palīgi, grāmatveži & Nav apzināts & 16 \\
\hline Mācībspēki IA jomā & Nav apzināts & 6 \\
\hline
\end{tabular}

Avots: autores veidota tabula.

Aptaujas respondentu sadalïjums (2.4. tabula) parāda, ka divas lielākās respondentu grupas pārstāv vairāk nekā $10 \%$ no generālkopas apjoma, kas l̦auj pètāmos rezultātus attiecināt uz visu generālkopu. Analizējot respondentu darbības jomas (2.7. attēls), redzams, ka lielākā daḷa respondentu (42\%) pārstāv valsts tiešās pārvaldes sektoru (ministrijas un valsts iestādes), tāpat daļa valsts un pašvaldību kapitālsabiedrību auditu (27\%) ir valsts tiešās pārvaldes iekšējo auditoru ziṇā, līdz ar to šis autores pētijums attiecināms uz valsts tiešās pārvaldes IA analizzi. 


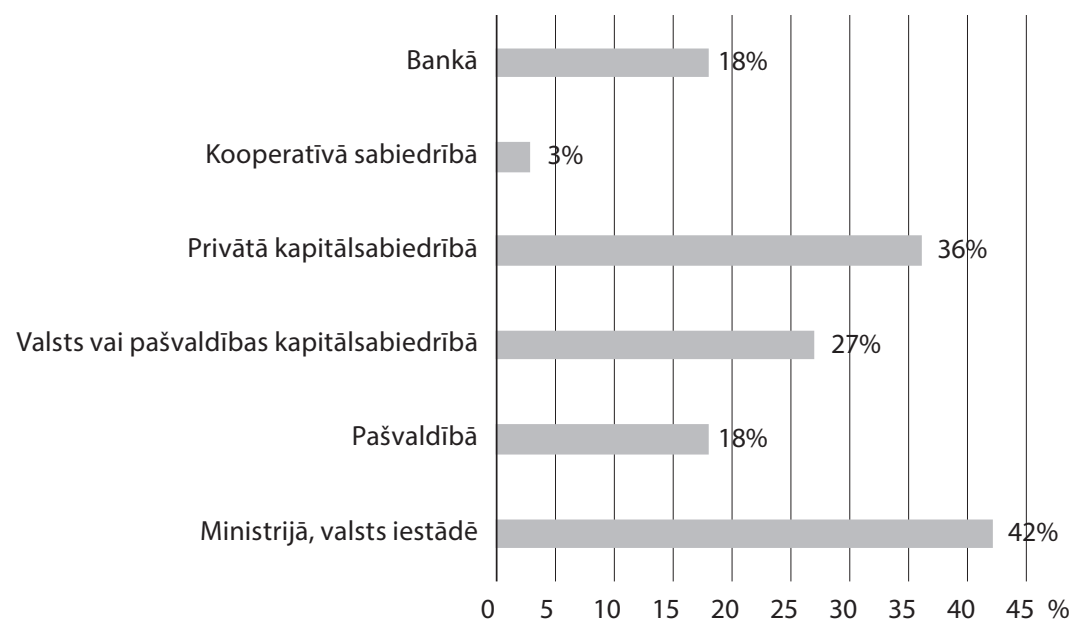

\section{7. attēls. Autores aptaujas anketas respondentu sadalījums pa darbības jomām (2010-2011, \%)}

Piezīme: respondenti varēja izvēlēties vairākus atbilžu variantus, tāpēc kopsummā atbilžu skaits neveido $100 \%$. Avots: autores veidota diagramma.

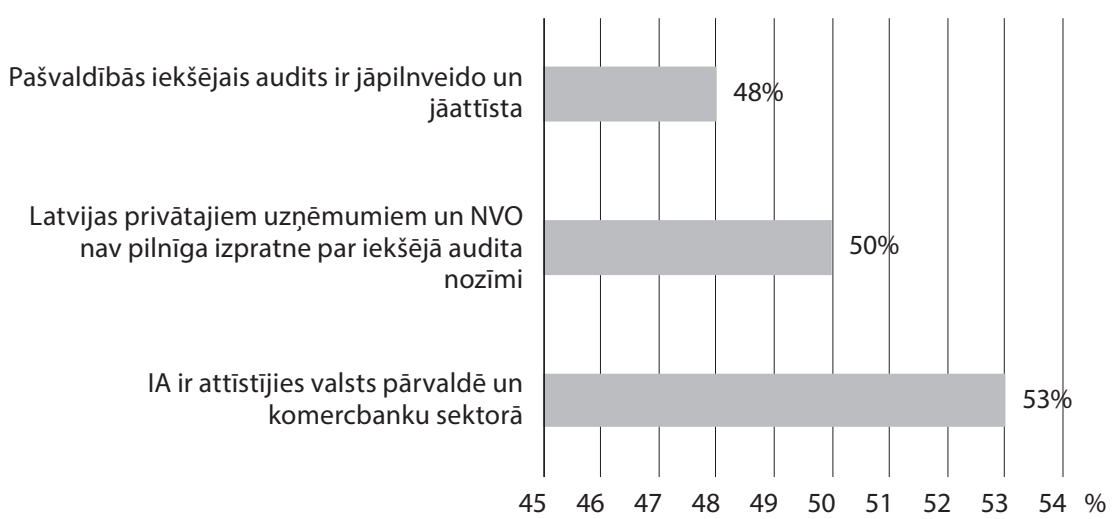

\section{8. attēls. Autores aptaujas iekšējo auditoru viedoklis par IA attīstību Latvijā (2010-2011, \%)}

Piezīme: respondenti varēja izvēlēties vairākus atbilžu variantus, tāpēc kopsummā atbilžu skaits neveido 100\%. Avots: autores veidota diagramma.

Uz jautājumu par respondentu IA attīstības vērtējumu Latvijā kopumā viedokḷi ir līdzīgi (2.8. attēls), jo visus apgalvojumus gandrīz 50\% respondentu uzskata par pareiziem, kas pierāda pētāmā jautājuma nozīmi un virzienu: gan respondentu viedoklis, ka pašvaldību IA ir jāpilnveido un jāattīsta, gan arī viedoklis, ka mācības ir l̦oti būtiska profesionalitātes un kompetences sastāvdaḷa. 


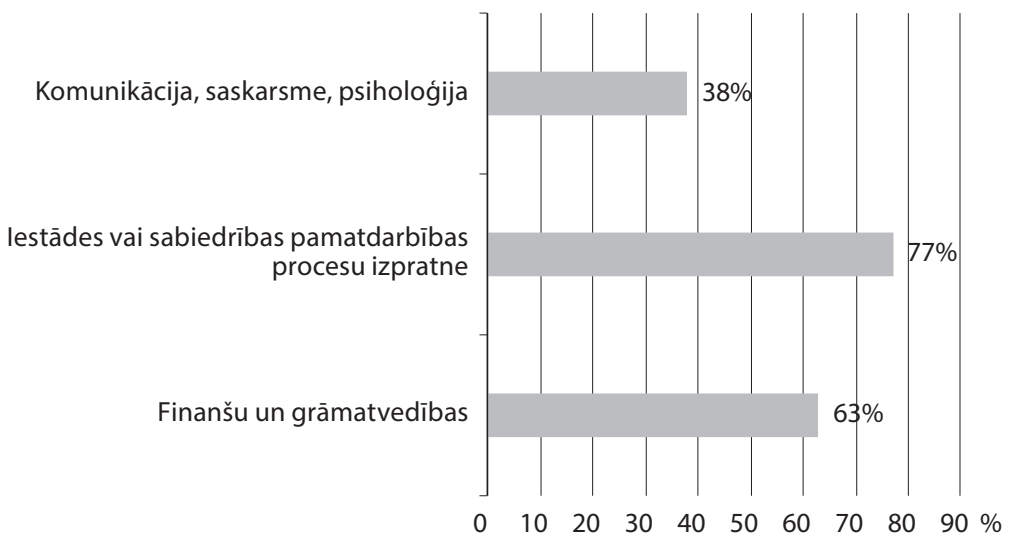

2.9. attēls. lekšējā auditora būtiskākās zināšanas autores aptaujas respondentu skatījumā (2010-2011, \%)

Piezīme: respondenti varēja izvēlēties vairākus atbilžu variantus, tāpēc kopsummā atbilžu skaits neveido 100\%. Avots: autores veidota diagramma.

Detalizēti analizējot anketēšanas rezultātus, autore izvirza vairākas cēloṇsakarības, kas ietekmē iekšêjā auditora darbu. Autore ir secinājusi, ka iekšējo auditoru apmācībām ir divi būtiski elementi:

1) apmācību pieejamība IA jomā (gan laiks, gan vieta, gan cena) un kvalitāte (lektora kvalifikācija un kursa saturs);

2) iekšējo auditoru zināšanu izmantošana (svarīgi, lai iekšējais auditors paliek savā darbā iespējami ilgāku laiku, nodrošinot, ka iegūtās zināšanas tiek efektīvi un lietderīgi izmantotas tieši IA jomā).

Autore secina, ka 2.9. attēlā iekḷautā informācija par iekšêjā auditora zināšanām pilnībā atbilst starptautiskajai praksei un IA būtībai, ka IA savas darbības rezultātā - IA ziṇojumā - sniedz vērtējumu par iestādes darbỉbu, tāpat ne mazāk būtiska nozīme ir zināšanām grāmatvedībā un finansēs, kā arī komunikācijai, saskarsmei un psihologisko procesu izpratnei.

Autore pilnībā piekrīt IAI izdevumā "IAI Vēstnesis" D. Nulles (septiņu gadu pieredze FM IAD direktores amatā) paustajam viedoklim par iekšejā auditora galvenajām īpašībām:

“1) profesionālās zināšanas, kurām jābūt tādām, kuras var respektēt pilnīgi visi: vai nu tas ir iestādes vadītājs, vai paši darbinieki. Tev ir jābūt autoritātei iestādē, lai tavā viedoklī ieklausītos, bet mēs jau saprotam, ka tas panākams tikai ar profesionālu darbu un izcilām jomas zināšanām, t. i., lai zināšanu skalu līmenī tiešām ir tie $90 \%$; 2) personiskās ìpašìbas: vai tev ir harizma, ar kuru vari piesaistìt 
iestādes un struktūrvienību vadītāju uzmanību, vai nav. (..) Tieši tāpēc auditoriem ir jābūt labām saziṇas iemaṇām, (..) jābūt saprotošam un nevajag uzṇemt vadītāju negācijas personīgi. Lìdz ar to runa nav tikai par auditora komunikācijas spējām, bet par cilvēcisko viedumu, l̦oti lielu empātiju un toleranci. (..) Iekšējam auditoram jābūt tādam, ka arī pēc nepatīkamā padoma abas puses ir vienojušās un ir saglabājušās labas personīgās attiecības. Un te nav runa par to, ka auditors ir paklausījies un nerīkojas, bet gan par to, kā viṇš spēj izskaidrot jautājumus. Auditoram ir jābūt gan augstai vērtību skalai, jābūt profesionālajām zināšanām, gan empātijai, tolerancei un spējai pārliecināt (..)" $)^{\prime 99}$

2011. gadā IAI vēstneša intervijā FM Audita un revīzijas departamenta vadītāja $\mathrm{N}$. Lasmane norādīja uz vairākām būtiskām IA profesijas attīstības komponentēm: "Publiskajā sektorā IA nonācis interesantā situācijā - ir ieviesta àrvalstu labākā prakse teorētiskā līmenī, laba metodika un sistēma, bet nav apmācīti paši šĩs sistēmas lietotāji (..). Manuprāt, Latvijas Republikas izglīîibas sistēmā ir l̦oti nepietiekama auditoru izglìtošana, faktiski izglītošana notiek darba procesā, bez jebkāda akadēmiska pamata valstī vai pašmācības ceḷā. Protams, arì tādas metodes var tikt izmantotas pie nosacijjuma, ka katrā struktūrvienībā ir pamats, uz kā IA var attīstīties - kolēgi ar ilgu darba pieredzi IA sistēmā un sertifikātiem. Diemžēl šì pamata bieži vien nav. Iestādes vadītājam ir jābūt ieinteresētam tajā, lai viņu iestādē IKS būtu l̦oti labi sakārtota, tikai tad viņšs būs ieinteresēts algot tādu IA komandu, kas palīdzēs to nodrošināt (..). Šobrīd auditori un vadītāji runā it kā dažādās valodās. Lai situāciju uzlabotu, MK ir akceptējis virkni dažādu plānu, kas, kā parasti, realizējas ḷoti gausi, jo pārsvarā sakārtota kontroles sistēma tiek uzskatīta par nevajadzīgu birokrātiju. Tā tas acīmredzot turpināsies, kamēr sabiedrība nesāks pieprasìt politisko un materiālo atbildību tieši no pašām atbildīgajām personām." 100

Pētỉjumā tika noskaidrotas iekšējo auditoru darbam nepieciešamo zināšanu apguves iespējas Latvijas augstākajās mācību iestādēs. Šobrīd vairākās augstskolās finanšu un grāmatvedības, kā arī risku vadības bakalaura studiju programmās tiek piedāvāts apgūt dažādus audita kursus, piemēram, "Audits"

\footnotetext{
${ }^{99}$ Ivanova I. (2014) Intervija ar IAI pirmās valdes locekḷiem Māri Graudinuu un Daci Nulli. IAI Vēstnesis, Nr. 7, 5.-10. lpp. Pieejams: http://iai.lv/wp-content/uploads/vestnesis_nr_7.pdf [skatīts 05.07.2015.] ${ }^{100}$ Grūba I. (2011) Auditors kustībā. Intervija ar FM Audita un revīzijas departamenta vadītāju Natu Lasmani. IAI Vēstnesis, Nr. 2, 2.-4. lpp.
} 
2.5. tabula. Ar IA saistītie kursi Latvijas augstskolās 2016./2017. akadēmiskajā gadā

\begin{tabular}{|c|c|c|}
\hline $\begin{array}{l}\text { Mācību iestāde, } \\
\text { fakultāte }\end{array}$ & Studiju programma & $\begin{array}{c}\text { Kursi un to aprakstos iekḷautie } \\
\text { jautājumi }\end{array}$ \\
\hline \multirow[t]{2}{*}{ Latvijas Universitāte } & $\begin{array}{l}\text { Profesionālā bakalaura studiju } \\
\text { programma "Grāmatvedība, analīze } \\
\text { un audits" }\end{array}$ & $\begin{array}{l}\text { "Audits" - ietver ārējā audita procesus } \\
\text { "lekšējā kontrole" }\end{array}$ \\
\hline & Maǵistra programma & "lekšējais audits" ietver IA procesus \\
\hline $\begin{array}{l}\text { Latvijas } \\
\text { Lauksaimniecības } \\
\text { universitāte }\end{array}$ & $\begin{array}{l}\text { EF maǵistra studiju programma } \\
\text { "Ekonomika", apakšprogrammas } \\
\text { "Finanses un kredīts" un } \\
\text { "Grāmatvedība un uzskaites teorija" }\end{array}$ & "lekšējais audits" ietver IA procesus \\
\hline $\begin{array}{l}\text { Rīgas Tehniskā } \\
\text { Universitāte }\end{array}$ & $\begin{array}{l}\text { "Uzñēmējdarbība un vadīšana", } \\
\text { profesionālā un bakalaura studiju } \\
\text { programma }\end{array}$ & $\begin{array}{l}\text { "Revīzija un audits" - ārējā audita } \\
\text { procesi }\end{array}$ \\
\hline $\begin{array}{l}\text { Ekonomikas un kultūras } \\
\text { augstskola }\end{array}$ & $\begin{array}{l}\text { Profesionālā bakalaura studiju } \\
\text { programma "Grāmatvedība un } \\
\text { audits" }\end{array}$ & "Kontrole, revīzija, audits"* \\
\hline \multirow{2}{*}{ Banku augstskola } & $\begin{array}{l}\text { Profesionālā bakalaura studiju } \\
\text { programma "Risku vadība un } \\
\text { apdrošināšana" }\end{array}$ & $\begin{array}{l}\text { "Audits" - ārējā audita procesi } \\
\text { "Risku matemātiskā analīze" } \\
\text { "Risku vadības pamati" }\end{array}$ \\
\hline & $\begin{array}{l}\text { Bakalaura studiju programmas } \\
\text { "Uzñēmējdarbības vadīšana", } \\
\text { "Finanses" }\end{array}$ & "lekšējais audits" \\
\hline
\end{tabular}

Avots: autores veidota tabula, pamatojoties uz augstskolu un universitāšu mājaslapās pieejamo informāciju.

* Kursu apraksti nav publiski pieejami.

vai "Revīzija un audits" (kas vairāk orientēts uz ārējo auditu un LR VK funkcijām), "Iekšējais audits", "Iekšèjā kontrole" u. c. kursus (2.5. tabula), taču nav tādu studiju kursu kā, piemēram, "Valsts pārvaldes iekšējais audits", "Pašvaldību iekšējais audits", "Publiskā sektora risku vadíba" vai "Pašvaldību iekšējā kontrole", kas dotu iespēju topošajiem speciālistiem sagatavoties iekšêjā auditora darbam valsts pārvaldē. Autore iesaka pilnveidot augstskolu studiju programmas, papildinot tās ar studiju kursiem IA jomā un to realizēšanu organizējot sadarbībā ar profesionāliem un valsts un pašvaldību iestāžu pārstāvjiem.

Vērtējot aptaujas rezultātus, jāsecina, ka grāmatvedības un finanšu jautājumi ieņem nozīmīgu lomu IA apjomā (2.10. attēls), kaut gan pēc starptautiskās prakses tā nevajadzētu būt, jo vajadzētu izmantot ārējo revidentu darbu. Pozitīi vērtējams, ka vispārējais IKS novērtējums ieņem otro vietu auditējamo jautājumu sarakstā, taču 2011. gadā iekšējie auditori vēl samērā maz uzmanības ir pievērsuši risku vadībai.

Risku vadības jomas nozīmīgums pēdējos gados arvien ir audzis ne tikai Latvijas valsts pārvaldē. Par to liecina Eiropas Komisijas apkopotais ziṇojums 


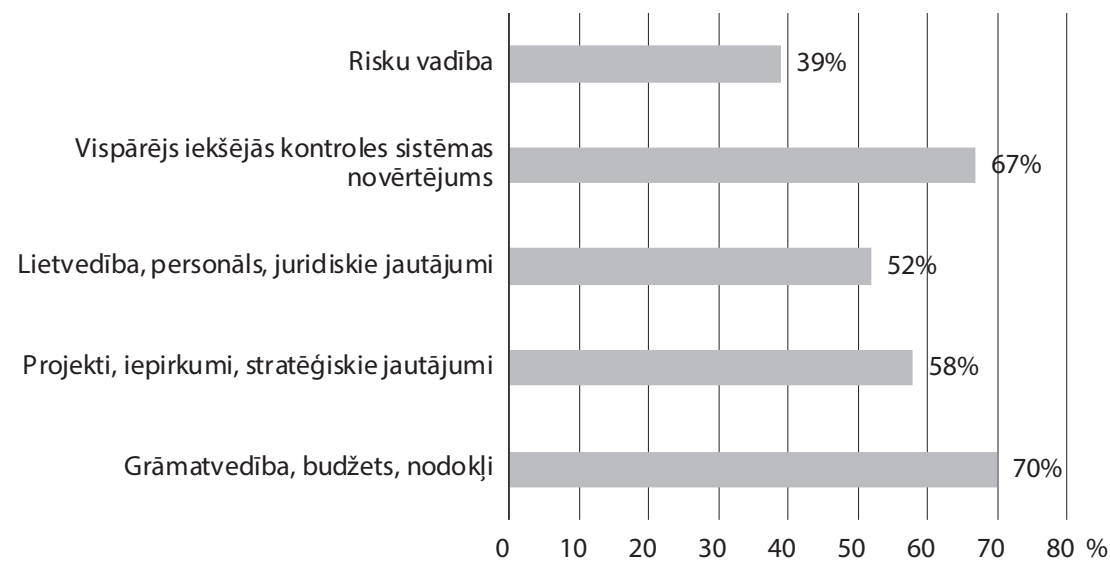

2.10. attēls. Autores aptaujā uzrādīto pēdējo divu gadu laikā auditētās jomas (2010-2011)

Piezīme: respondenti varēja izvēlēties vairākus atbilžu variantus, tāpēc kopsummā atbilžu skaits neveido 100\%. Avots: autores veidota diagramma.

par IKS 28 ES dalībvalstu publiskajā sektorāân ${ }^{101}$, jo daudzās valstīs, arī Latvijas valsts tiešajā pārvaldē, vadītāji pievērš lielu, dažbrīd pat pārspīlētu uzmanību risku vadības pasākumiem, nevis iestādes izvirzìto mērḳu sasniegšanai.

\section{2. lekšējā audita sistēma Latvijas pašvaldībās}

\subsubsection{Latvijas pašvaldību raksturojums}

18.12.2008. ar Saeimas pieņemto Administratīvo teritoriju un apdzīvoto vietu likumu beidza pastāvēt 26 rajonu pašvaldības, un iepriekšējo 522 vietējo pašvaldību vietā izveidojās 118 pašvaldības. Pēc 03.01.2011. grozījumiem Administratīvo teritoriju un apdzīvoto vietu likumā Latvijā ir 119 pašvaldỉbas - deviņas republikas pilsētas un 110 novadi. Administratīvo teritoriju un apdzīvoto vietu likums paredz izveidot arī apriṇkusus kā valsts administratīvās teritorijas. Šobrīd kā koordinācijas un sadarbības institūcijas turpina pastāvēt plānošanas reǵioni. ${ }^{102}$

\footnotetext{
${ }^{101}$ European Commission (2014) Compendium of the Public Internal Control Systems in the EU Member States. Second edition, Luxembourg: Publications Office of the European Union. ISBN: 978-922-79-37868-3. Available at: http://ec.europa.eu/budget/pic/compendium/index_en.cfm [cited 25.03.2018.]

${ }^{102}$ Valsts reǵionālās attīstîbas aǵentūra (2011), Reǵionu attīstība Latvijā 2010. Rīga, 171 lpp.
} 
Kopš 2003. gada Latvijas valdība ir apstiprinājusi piecus plānošanas reǵionus (Rīgas, Vidzemes, Latgales, Kurzemes un Zemgales).

Likuma "Par 1985. gada 15. oktobra Eiropas vietējo pašvaldību hartu" 3. pants nosaka to, ka "vietējā pašvaldība nozīmē vietējās varas tiesības un spēju likumā noteiktajās robežās regulēt un vadīt nozīmīgu valsts lietu daļu uz savu atbildību un vietējo iedzīvotāju interesēs. Šīs tiesības realizē padomes vai pārstāvju sapulces, kuru locekḷus brīvi ievēlē, aizklāti balsojot uz vienlīdzīgu, tiešu un vispārēju vēlēšanu tiesību pamata; tām var būt pakḷautas izpildinstitūcijas. Šis princips nekādā veidā neietekmē tiesības izmantot pilsoṇu sapulces, referendumus vai jebkuru citu pilsoṇu tiešās līdzdalības formu, kur to piel̦auj likums"103.

Likuma "Par pašvaldībām" 3. pants noteic, ka vietējā pašvaldība ir vietējā pārvalde, kas ar pilsoṇu vēlētas pārstāvniecības - domes un tās izveidoto institūciju un iestāžu starpniecību nodrošina likumos noteikto funkciju, kā arī šajā likumā paredzētajā kārtībā Ministru kabineta doto uzdevumu un pašvaldības brīvprātīgo iniciatīvu izpildi, ievērojot valsts un attiecīgās administratīvās teritorijas iedzìvotāju intereses. Savukārt Valsts pārvaldes iekārtas likuma 1. pants nosaka to, ka atvasināta publiska persona ir pašvaldíba vai cita ar likumu vai uz likuma pamata izveidota publiska persona. Tai ar likumu ir piešķirta sava autonoma kompetence, kas ietver arī sava budžeta veidošanu un apstiprināšanu. Tai var būt sava manta. Likuma 8. panta ceturtā dal̦a skaidro, ka pašvaldība, pildot valsts pārvaldes funkcijas, kas saskaṇā ar likumu nodotas tās autonomā kompetencē, atrodas MK pārraudzībā likumā "Par pašvaldībām” noteiktajā kārtībā un apjomā.

Apkopojot visas trīs normatīvajos aktos ietvertās definīcijas, autore secina, ka pašvaldība ir atvasināta publiska persona ar pilsoṇu vēlētu vietējo pārvaldi un autonomu kompetenci, kas nodrošina likumos noteikto, MK uzdoto brīvprātīgu iniciatīvu izpildi, ievērojot vietējo iedzīvotāju intereses.

Likuma “Par pašvaldību budžetiem” 20. un 21. pantā noteikts, ka Latvijas Republikas pilsētu un novadu budžetu ieņēmumus veido atskaitījumi no valsts nodokḷiem un nodevām, pašvaldību nodevas, valsts budžeta dotācijas un mērḳdotācijas, dotācijas no pašvaldību finanšu izlīdzināšanas fonda, norēḳini ar pašvaldību budžetiem, maksājumi par pakalpojumiem, atskaitījumi no kapitālsabiedrību pel̦nas, ien̦ēmumi no pašvaldību īpašuma iznomāšanas (izīrēšanas), īpašuma pārdošanas un citi ar likumu noteikti ieņēmumi. Lai pašvaldībām nodrošinātu līdzīgus apstākḷus to funkciju izpildei, izveido pašvaldību finanšu ${ }^{103}$ Eiropas vietējo pašvaldību harta. Eiropas Padome, Nr. 122. Strasbūra, 15.10.1985. Pieejams: https://m.
likumi.lv/doc.php?id=39149 [skatīts 22.04.2017.] 
izlīdzināšanas fondu. Līdzekḷus pašvaldību finanšu izlīdzināšanas fondā no pašvaldību vai valsts ieņēmumiem ieskaita, kā arī no pašvaldỉbu finanšu izlīdzināšanas fonda izmaksājamo dotāciju apjomu noteic normatīvajos aktos paredzētajā kārtībā. Lai nostiprinātu reǵionu ekonomisko bāzi un nodrošinātu valsts funkciju izpildi, no valsts budžeta var piešķirt dotācijas un mērķdotācijas noteiktu uzdevumu izpildei. Dotācijas un mērḳdotācijas, kas no valsts budžeta tiek piešķirtas noteiktu uzdevumu izpildei, nav pašvaldību finanšu izlīdzināšanas fonda sastāvdaḷa. Latvijas nodokḷu ien̦ēmumi, kas ietekmē Latvijas pašvaldību budžetu 2017. gadā, ir atspoguḷoti 2.6. tabulā.

\section{6. tabula. Latvijas nodokḷu ieṇēmumu sadalijums pa budžetiem (\% no kopējiem ieṇēmumiem) 2017. gadā}

\begin{tabular}{|c|c|c|c|}
\hline $\begin{array}{l}\text { Nr. } \\
\text { p. k. }\end{array}$ & Nodokḷa veids & $\begin{array}{c}\text { Valsts } \\
\text { pamat- } \\
\text { budžets (\%) }\end{array}$ & $\begin{array}{c}\text { Pašvaldību } \\
\text { budžets } \\
(\%)\end{array}$ \\
\hline 1. & ledzīvotāju ienākuma nodoklis & 20 & 80 \\
\hline 2. & Nekustamā īpašuma nodoklis & & 100 \\
\hline 3. & Izložu un azartspēḷu nodoklis no azartspēlēm & 75 & 25 \\
\hline 4. & Izložu un azartspēḷu nodoklis no vietējā mēroga izlozēm & & 100 \\
\hline 5. & $\begin{array}{l}\text { Dabas resursu nodoklis par dabas resursu ieguvi vai vides } \\
\text { piesārņošanu }\end{array}$ & 40 & 60 \\
\hline 6. & Dabas resursu nodoklis par radioaktīvo vielu izmantošanu & & 100 \\
\hline 7. & $\begin{array}{l}\text { Dabas resursu nodoklis par oglekḷa dioksīda }\left(\mathrm{CO}_{2}\right) \text { emisijām gaisā } \\
\text { (no 2017. gada) }\end{array}$ & 60 & 40 \\
\hline 8. & $\begin{array}{l}\text { Dabas resursu nodoklis par zemes dzīḷu derīgo īpašību } \\
\text { izmantošanu, iesūknējot ǵeoloǵiskajās struktūrās dabasgāzi }\end{array}$ & & 100 \\
\hline
\end{tabular}

Avots: autores veidota tabula pēc Latvijas Republikas Finanšu ministrijas datiem (2017).

Pašvaldību kontos un kasēs ienāk ievērojama daḷa nodokḷu summu (2.6. tabula), kas, pēc autores domām, ir būtisks iemesls pašvaldību kvalitatīva, neatkarīga, objektīva iekšèjā un ārējā audita nozīmīgajai lomai, ar ko varētu vērtēt, cik efektīva, racionāla un atbilstoša ir Latvijas pašvaldību ieņēmumu sadale izdevumos un tālāk izdevumu atbilstība paredzētajiem mērķiem.

Baltijas valstu un ES valstu vidējie rādītāji par 2011.-2016. gada periodu procentos apkopoti 2.11. un 2.12. attēlā, kur redzams, ka gan pašvaldību ien̦ēmumi, gan pašvaldỉbu izdevumi visām Baltijas valstīm kopumā ir salīdzinoši tuvu vidējiem rādītājiem ES valstīs. Autore analizēja šo rādìtāju, lai parādītu, ka pašvaldību ieṇēmumi un izdevumi veido vairāk nekā ceturto daḷu no visa kopbudžeta, kas ir būtiska daḷa. Tā kā IA apjoms piecu gadu stratēgiskajā plānā aptver visas institūcijas funkcijas un uzdevumus, tai skaitā arī ieņēmumu un 


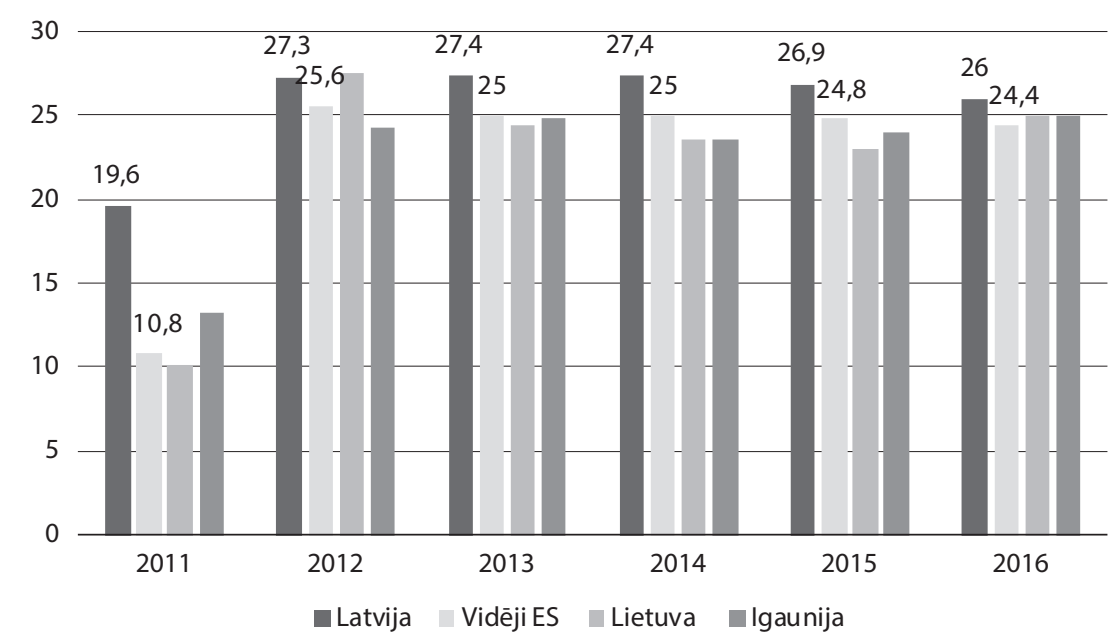

\subsection{1. attēls. Baltijas valstu un vidēji ES pašvaldību ieṇēmumu īpatsvars kopējos valdības ieṇēmumos* (2011-2016, \%)}

* Konsolidētā kopbudžeta uzskaites korekcijas atbilstoši Eiropas kontu sistēmas metodologiijai. Avots: autores veidots attēls, pamatojoties uz Finanšu ministrijas datiem.

izdevumu veidošanas atbilstības novērtējumu, IA loma šajās institūcijās uzskatāma par l̦oti nozīmīgu.

Atbilstoši informācijai, ko publicējusi FM, 2016. gadā Latvijas pašvaldību ien̦ēmumu īpatsvars kopējos ien̦ēmumos, salīdzinot ar iepriekšējiem četriem gadiem, ir pakāpeniski samazinājies, un, salīdzinot ar 2015. gadu, samazinājies par 0,9 procentpunktiem. Igaunijā un Lietuvā pašvaldību ien̦ēmumu īpatsvars kopējos valdības ieṇēmumos ir bijis zemāks nekā Latvijā, taču 2016. gadā nedaudz pārsniedzis ES vidējos rādītājus.

Kopumā secināms, ka Baltijas valstīs ien̦ēmumu īpatsvara izmaiņas vispārējās valdības ieņēmumos jeb kopbudžetā pēdējos trijos gados ir atškirīigas, piemēram, Lietuvā laika periodā no 2012. gada līdz 2015. gadam ir vērojams ieṇēmumu samazinājums, taču 2016. gadā, salīdzinot ar iepriekšējo pārskata gadu, ir pieaugums par diviem procentpunktiem, savukārt Igaunijā kopš 2013. gada vērojams ieņēmumu samazinājums aptuveni par vienu procentpunktu katru gadu.

Atbilstoši informācijai, ko publicējusi FM kopumā, var secināt, ka Latvija pašvaldību ieņēmumu un arī izdevumu īpatsvarā ieņem 1. vietu starp Baltijas valstīm un visos gados pārsniedz ES valstu vidējos rādītājus. Aptuveni viena trešdaḷa no valsts kopbudžeta ieṇēmumiem un izdevumiem ir Latvijas pašvaldỉbu finanšu resursi. 


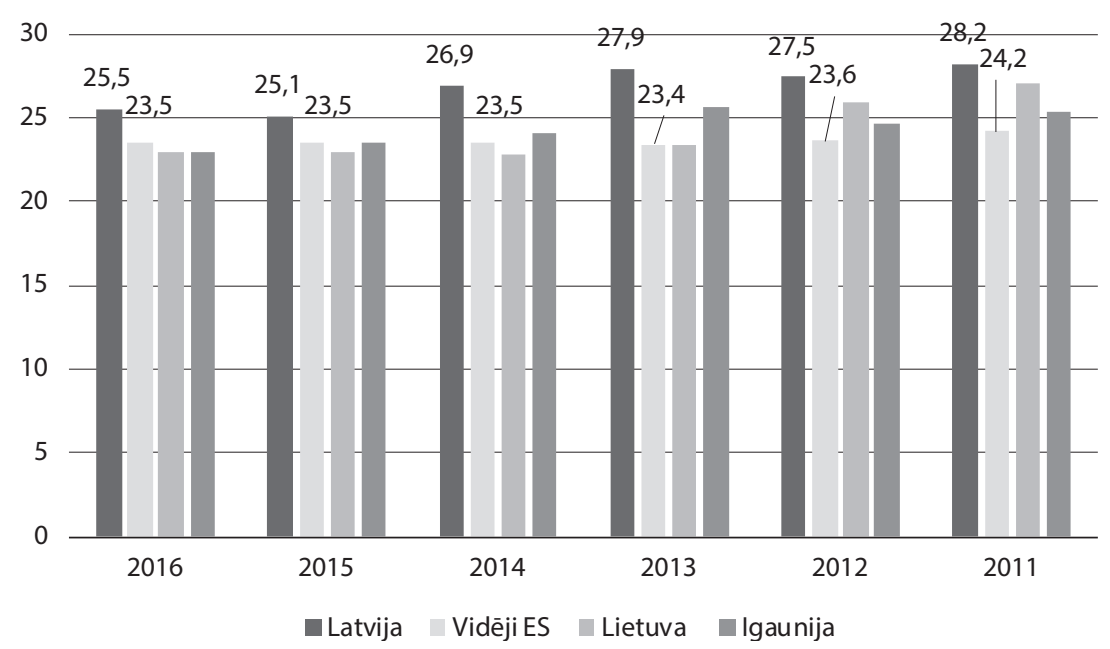

2.12. attēls. Baltijas valstu un vidēji ES pašvaldību izdevumu īpatsvars vispārējās valdības izdevumos* (2011-2016, \%)

* Konsolidētā kopbudžeta uzskaites korekcijas atbilstoši Eiropas kontu sistēmas metodologiijai. Avots: autores veidots attēls, pamatojoties uz Finanšu ministrijas datiem (2017).

Tajās valsts pārvaldes iestādēs un pašvaldībās, kurās ir ieviesta kvalitātes vadības sistēma, IA uzdevums tiek aplūkots integrēti - ar audita ieteikumiem var uzlabot gan kvalitātes vadības sistēmu, gan arī IKS. Tiesa, šīm iestādēm ir cita veida izaicinājums - dokumentācijas apjoms IA un kvalitātes audita veikšanai ir atšķirīgs. Proti, iekšējais kvalitātes audits paredz krietni mazāku aizpildāmo dokumentu skaitu. Iestādēm, kurās ir gan IA, gan kvalitātes vadības sistēma, dažkārt nākas uzturēt divu veidu dokumentu kopas - vienu par IA, otru par iekšējo kvalitātes auditu. Tā kā abos auditos tiek izmantota procesu pieeja, tikai no iestādes darbinieku kvalifikācijas un izpratnes ir atkarīgs tas, cik lielā mērā ir iespējama abu auditu integrācija, izvairoties no darbību dublēšanas. ${ }^{104}$

"Eiropas vietējo pašvaldību hartas" 9. pantā ir noteikts, ka "vietējām varām valsts ekonomiskās politikas ietvaros ir tiesības uz pietiekamiem pašu finanšu resursiem, ar kuriem tās drīkst brīvi rìkoties savu pilnvaru robežās, un finanšu sistēmām, uz kurām ir balstīti vietējām varām pieejamie līdzekḷi, ir jābūt pietiekami daudzveidīgām un elastīgām, lai tās praktiski dotu iespēju sekot

\footnotetext{
${ }^{104}$ Nikolo grupa (2011) Auditoru interviju apkopojums. Nodevums pētījumā "Iekšējās kontroles sistēmas novērtējums un rekomendāciju izstrāde". Rīga, 20 lpp.
} 
izpildāmo uzdevumu izmaksu patiesajai attīstībai”105. Fakts, ka līdzekḷi netiek izlietoti atbilstoši apzināti un/vai neapzināti, dažādās publikācijās ir pierādīts jau vairākus gadus pēc kārtas.

Analizējot Latvijas pašvaldības, svarīga un, autoresprāt, vērā n,emama ir LR VK kā augstākās audita iestādes Latvijā publiskotā informācija (ziṇojumi) par nelietderīgiem tēriniiem dažādās valsts un pašvaldību iestādēs, kaut gan normatīvajos aktos ir paredzētas obligātās zvērinātu revidentu pārbaudes. Autore pētỉjumā iekḷāvusi un analizējusi LR VK 2014., 2015. un 2016. gada ziņojumus. Revīzijas ziņojumā "Par Latvijas Republikas 2013. gada pārskata par valsts budžeta izpildi un par pašvaldību budžetiem pašvaldību gada pārskatu dalıu”106, lai gūtu pārliecību par pašvaldību gada pārskatu daḷas sagatavošanas atbilstību normatīvo aktu prasībām, revīzijas izlasē tika iekḷautas 29 pašvaldỉbas: sešas republikas pilsētu pašvaldības un 23 novadu pašvaldības. Revidenti skaidro, ka par 119 pašvaldību 2013. gada pārskatiem zvērināti revidenti ir snieguši šādus atzinumus: bez iebildēm - 110 pašvaldībām, tajā skaitā četru republikas pilsētu un 106 novadu pašvaldībām, ar iebildēm - astoṇām pašvaldībām, vienai - negatīvs atzinums.

Jautājuma būtības uztveršanai lietderīgi ir izskatīt atsevišķas iebildes zvērinātu revidentu atzinumos, ko apkopojusi LR VK: par pārskata perioda sākuma atlikumu atbilstību; par ziedojumu budžeta izdevumu neatbilstošu klasifikāciju; par revīzijas ierobežojumiem, kas saistīti ar 2013. gada bilances posteņu inventarizēšanu; par bilances posteņu klasifikācijas neatbilstību virsgrāmatas datiem; par ilgtermiņa ieguldījumu neatbilstošu novērtējumu un klasifikāciju; par grāmatvedības politikas nepiemērošanu konsolidācijā iesaistītajās iestādēe ${ }^{107}$. LR VK secināja - 62\% no izlasē iekḷautajām pašvaldībām sniegtā informācija nav patiesa, salīdzināma, nozīmīga, saprotama vai pilnīga, kā rezultātā tā ietekmē pašvaldību gada pārskata daḷas kvalitāti, tajā skaitā iekḷautās informācijas pilnīgumu un patiesumu. LR VK izstrādāja ieteikumu: FM izvērtēt nepieciešamību veikt tā normatīvā regulējuma pilnveidošanu, kas nosaka gada pārskatu sagatavošanas kārtību, lai nepiel̦autu revīzijā konstatētās nepilnības informācijas atklāšanā gada pārskatos. LR VK 2015. gada ziņojumā par 2014. gada pašvaldību

\footnotetext{
${ }^{105}$ Eiropas vietējo pašvaldību harta. Eiropas Padome, Nr. 122. Strasbūra, 15.10.1985. Pieejams: https://m. likumi.lv/doc.php?id=39149 [skatits 22.04.2017.]

${ }^{106}$ Par Latvijas Republikas 2013. gada pārskata par valsts budžeta izpildi un par pašvaldību budžetiem pašvaldïbu. LR VK, Revizijas ziņojums. 15.09.2014. Pieejams: http://www.lrvk.gov.lv/uploads/ reviziju-zinojumi/2013/5.1-2-32-2_2013/pasvaldibu-zinojums-publiskosanai-02-10-2014.pdf [skatits 06.06.2015.]

${ }^{107}$ Turpat.
} 
pārskatiem konstatēja, ka pašvaldỉbās nav izpratnes par grāmatvedības uzskaites kārtību un trūkst iekšējās kontroles ${ }^{108}$.

Valsts kontroliere E. Krūmiņa uzskata, ka būtiskākās problēmas ir saistītas ar gada inventarizācijas veikšanu un ilgtermiņa ieguldījumu uzskaiti. Pašvaldībās, tāpat kā 2013. gadā un iepriekšējos gados, ir konstatētas gan fundamentālas kḷūdas ilgtermiņa ieguldījumu uzskaitē, gan finanšu līdzekḷu piesavināšanās gadījumi. LR VK ieskatā, minētos trūkumus izraisa dažu pašvaldību vadītāju nespēja nodrošināt atbilstošu iekšējās kontroles vidi, nevēlēšanās rīkoties atbilstoši normatīvo aktu prasībām vai nepilnības normatīvajos aktos, kā arī - dažos gadījumos - zvērinātu revidentu darbs, pārbaudot pašvaldību gada pārskatu sagatavošanas atbilstību spēkā esošo normatīvo aktu prasībām, nav pietiekams ${ }^{109}$. 2016. gada LR VK ziņojums par pašvaldību 2015. gada pārskatiem ${ }^{110}$ ietver revidentu viedokli, ka pašvaldībās ir neatbilstoša, neefektīva IKS vai konstatēta tās neesība. Rezultātā ir piel̦autas kḷūdu izraisìtas neatbilstības un normatīvajiem aktiem neatbilstoša grāmatvedības uzskaites kārtošana, kas būtiski ietekmē pašvaldību pārskatos uzrādītās informācijas kvalitāti. LR VK ieskatā tiek norādīta kontroḷu neesība pamatdarbības procesos: īpašuma uzskaitē un pārvaldīšanā, naudas līdzekḷu maksājumu veikšanas procesā, iepirkumu veikšanas procesā un materiālo vērtîbu norakstǐšanā. LR VK veiktajā 119 pašvaldību vadītāju aptaujā apkopotie dati liecina, ka 34\% normatīvajos aktos noteikto prasību IKS nav saprotamas, 94\% uzskata, ka IKS ir liela nozīme, $60 \%$ vēlas uzlabot savas zināšanas par IKS, 4\% (piecās pašvaldībās) ieviesta kvalitātes vadības sistēma, $40 \%$ uzskata, ka vislabāk IKS pilnveidošanu veicinātu skaidrāk noteiktas, uz pašvaldībām attiecinātas normatīvo aktu prasības, 22\% uzskata, ka vislabāk IKS veicinātu augstākā un vidējā līmeṇa vadītāju apmācỉba un pieredzes apmaiṇa starp pašvaldībām. LR VK iesaka MK ierosināt grozījumus normatīvajos aktos, paredzot skaidrāk noteiktas uz pašvaldībām attiecināmas prasības par IKS, tāpat nodrošināt augstākā un vidējā līmeņa vadītāju apmācību iespējas par IKS. Ieteikumi sākotnēji tika sniegti FM, taču FM tos neatbalstija, skaidrojot, ka darbības ieviešana ir citu ministriju/iestāžu kompetences jautājums.

VARAM atzinīgi novērtēja LR VK revīzijas ziņojumā iekl̦autos secinājumus un ieteikumus, kas ir nozīmīgi tālākai pašvaldību darbības sistēmas pilnveidei.

\footnotetext{
${ }^{108}$ Kubliņš I. (2016) Grāmatvedim nebūtu jārīkojas pretēji profesionālajai un ētiskajai pārliecībai" Intervija ar Elitu Krūminuu. Bilance, Nr. 11/12 (383/384), 7.-11. lpp.

${ }^{109}$ Revīiijas ziṇojums par LR 2014. gada pārskata par valsts budžeta izpildi un par pašvaldību budžetiem Pašvaldību gada pārskatu daḷu. 364. lpp. Pieejams: http://www.lrvk.gov.lv/uploads//revizijuzinojumi/2014/2.4-1-39_2014/sgp_zinojums_01102015.pdf [skatīts 18.08.2016.]

${ }^{110}$ Turpat.
} 
Tie parāda realitāti pašvaldībās un norāda virzienus, kuros būtiski vajadzētu izvērtēt un pārskatīt tiesisko regulējumu, kā arī nodrošināt metodisko atbalstu. VARAM regulāri pilnveido metodiskos ieteikumus attīstības programmu izstrādei vietējā līmenī un organizē vietējo pašvaldību attīstības plānošanas speciālistu kapacitāti stiprinošos pasākumus. Līdz ar to revīzijas secinājumi un piemēri sniedz būtisku ieguldījumu VARAM darbā attīstības plānošanas kvalitātes un efektivitātes vietējā līmenī uzlabošanai ${ }^{111}$.

Kopumā secināms, ka kḷūdas un nepilnības konstatētas 2013., 2014. un 2015. gada pārbaudēs un līdz šim nav izdevies mazināt trūkumus IKS, jo IA, kas ir viens no galvenajiem instrumentiem, ar savām pārbaudēm un ziņojumiem, ar konsultācijām un ieteikumiem var nodrošināt pašvaldību IKS sakārtošanu.

Autore uzskata, ka vienota IA ieviešana Latvijas pašvaldībās, paredzot starptautisko standartu ievērošanu auditoru darbā, ir instruments, ar kura palīdzību var nodalīt zvērinātu revidentu, IA un LR VK auditējamās lomas, kā arī novērst funkciju pārklāšanos vai dublēšanos (sk. 3.2. nodaḷu). Ar IA funkcijas ieviešanu būtu iespējams sakārtot IKS, sniedzot novērtējumu un ieteikumus trūkumu novēršanai, kā arī dažādus konsultatīvos pakalpojumus, ja politiskie aspekti netraucētu kvalitatīvam iekšèjo auditoru darbam.

2014. gada vasarā Valsts kanceleja izstrādāja Valsts pārvaldes attīstības pamatnostādnes 2014.-2020. gadam. VARAM tika doti divi uzdevumi:

1) valsts institūciju savstarpējās sadarbības pilnveidošanai noteikt reǵionālo valsts teritoriālo iedalījumu ar administratīvajiem centriem;

2) konsultējoties ar pašvaldībām, noteikt valstī administratīvo teritoriju grupas ap reǵionālās un nacionālās nozīmes centriem, kuru ietvarā pašvaldỉbas var apvienoties un sadarboties.

Likumdošanā ir noteikta apriņ̧̧̧u izveide, tāpēc ka šobrīd 38 pašvaldības ir mazākas un neatbilst likumā noteiktajam kritērijam par 4000 iedzīvotājiem, turklāt ne visas spēj labi pildīt pašvaldībām uzliktās funkcijas, jo nepietiek kapacitātes. ${ }^{112}$

Uz jautājumu, vai pašvaldību rīcība ar mantu un finanšu līdzekḷiem, nodrošinot savām funkcijām atbilstošus maksas pakalpojumus iedzīvotājiem, ir

\footnotetext{
${ }^{111}$ VARAM (2017) Par informatīvo ziņojumu "Par valsts administratīvi teritoriālo iedalijumu un valsts pārvaldes institūciju sadarbības teritoriju izveidi”. Pieejams: http://www.lps.lv/uploads/ docs_module/Par\%20informat\%C4\%ABvo\%20zi\%C5\%86ojumu\%20\%E2\%80\%9CPar\%20valsts\%20 administrat\%C4\%ABvi\%20teritori\%C4\%81lo\%20iedal\%C4\%ABjumu\%20un\%20valsts\%20p\%C4\%81rvaldes\%20instit\%C5\%ABciju\%20sadarb\%C4\%ABbas\%20teritoriju\%20izveidi\%E2\%80\%9D.pdf [skatits 17.04.2017.]

${ }^{112}$ Klismeta G. Saruna ar VARAM ministru K. Gerhardu. Vai nu "A" vai "B". Logs, 2017, Nr. 1 (259). Pieejams: http://www.lps.lv/lv/zurnals-logs-infolapa/zurnals-logs/ [skatits 22.04.2017.]
} 
efektīva un ekonomiska un vai pašvaldību administratīvais resurss to funkciju īstenošanai tiek izlietots produktīvi un ekonomiski, nepārprotamas atbildes nav, taču, autoresprāt, tieši IA ar saviem ziņojumiem spēs atbildēt gan par efektivitātes, gan par ekonomiskuma īpatsvara palielināšanu pašvaldību funkciju īstenošanā.

\subsubsection{Latvijas pašvaldību iekšējā audita pieejas}

Uz 2018. gadu spēkā esošajā "Iekšēja audita likuma" 3. panta otrajā daḷā noteikts: "Atvasinātas publiskas personas iekšējā audita sistēmu, iekšējā audita darba organizāciju un iekšējā audita veikšanas kārtību nosaka tās lēmējinstitūcija. Lai nodrošinātu iekšējā audita funkcijas efektīvāku veikšanu, atvasinātas publiskas personas lēmējinstitūcija, ja nepieciešams, var slēgt sadarbības līgumu ar attiecīgās nozares ministriju par šìs personas iekḷaušanu ministrijas iekšèjā audita sistēmā." ${ }^{113}$ Minētā likuma norma rada situāciju, kurā katra pašvaldība lemj individuāli, vai tai ir nepieciešama IAS vai nav.

13.12.2012. pieņemtajā Iekšèja audita likuma anotācijā FM skaidro: "Lai atvasinātām publiskām personām nodrošinātu vienotas iekšèjā audita sistēmas izveidošanas prasības, no likuma paredzēts izslēgt prasību atvasinātās publiskās personās veidot iekšèjā audita sistēmu. Par iekšèjā audita sistēmas izveides nepieciešamību atvasinātās publiskās personās lemj atvasinātas publiskas personas lēmējinstitūcija." 114

2016. gada pētījumā (sk. 4. pielikumu) autore konstatējusi, ka paši pašvaldību iekšejjie auditori kā vienu no pašvaldību IA attīstību kavējošiem faktoriem min normatīvo aktu un vienotas IA metodikas trūkumu, kā arī pašvaldību vadỉbas neizpratni par IKS un IA lomu iestādes sistēmā kopumā.

Lai padziḷināti izpētītu situāciju valsts un pašvaldību iestāžu iekšējās kontroles jomā, lietišķo pētījumu aǵentūra "Nikolo grupa" laikā no 2010. gada janvāra līdz maijam veica tiešās dal̦ēji strukturētās intervijas ar 40 valsts tiešās pārvaldes iestāžu un 30 pašvaldību iestāžu iekšējiem auditoriem. Vairākos gadījumos pašvaldību auditori uzsvēra, ka IAS vai iekšēja auditora amata izveidošana pašvaldībā ir bijis pašvaldības darbu pozitīvi ietekmējošs faktors, kas šajā gadījumā jāsaista ar novada vadības lēmumu un kopējo pašvaldības administratīvo kultūru. Pašvaldību auditori norādīja, ka pašvaldībām trūkst tikpat skaidru nosacījumu personāla atlases konkursu rīkošanai kā valsts pārvaldei.

\footnotetext{
${ }^{113}$ Iekšèjā audita likums (2012). LR likums spēkā no 11.01.2013. Pieejams: http://likumi.lv/doc. php?id=253680 [skatits 29.06.2015.]

${ }^{114}$ Turpat.
} 
Ir pašvaldības, kurās iekšējais audits pastāv un iekšējā audita darbībā tiek izmantotas tās pašas metodes, pieejas, vadlīnijas, kuras izmanto valsts pārvaldes iestādes. Tā kā IA tiek veikti regulāri, institūciju darbiniekiem tiek raidìts signāls par to, ka kontroles aktivitātes ir regulāras. Intervijās tika arī norādīts, ka dažkārt iekšējie auditori tiek iesaistīti disciplinārlietu izmeklēšanas komisijās, tādēl darbinieki pret auditu izturas mazliet piesardzīgi. ${ }^{115}$

R. Šulca savā pētījumā ${ }^{116}$ konstatējusi, ka Latvijā 2010. gadā IA funkcija darbojās 17 pašvaldībās. Laikam ejot, ir mainījies gan pašvaldību skaits, gan arī pašvaldības, kurās ieviests un darbojas IA kā IKS novērtētājs un padomdevējs vadībai.

2013. gada beigās pētījuma "Latvijas pašvaldības un IA" elektroniska aptauja tika izsūtīta IAS vadītājiem Latvijas pašvaldībās, tāpat LPS pārstāvjiem, kas publicēja informāciju par aptauju savā mājaslapā un izsūtỉja visām 119 Latvijas pašvaldībām. Aptaujas anketu aizpildīja 29 Latvijas pašvaldību pārstāvji, kas kopumā veido $24,37 \%$ izlasi no visas generālkopas, kas uzskatāma par pietiekamu datu analīzei un rezultātu attiecināšanai uz generālkopu jeb Latvijas pašvaldībām kopumā. $40 \%$ no aptaujātajām pašvaldībām ir izveidota IAS vai pieņemts darbā iekšējais auditors, savukārt $60 \%$ gadỉjumu IA nav ieviests.

2016. gada jūlijā un augustā autore veica trešo aptauju "Latvijas pašvaldību IA novērtējums". Aptaujā piedalijāa un anketu aizpildīja sešu Latvijas pašvaldỉbu iekšējie auditori, pārstāvot 27,27\% no kopējā Latvijas pašvaldību skaita ar IA funkciju. Kopumā aptaujātajās pašvaldībās lielākoties ir struktūrvienības ar vienu auditoru, bet ir dažas pašvaldības, kurās ir divi, trīs vai vairāk nekā pieci auditori.

Gan 2013. gadā, gan 2016. gadā pašvaldību iekšējie auditori savā darbā galvenokārt izmantoja Latvijas Republikas normatīvos aktus un pašvaldību saistošos noteikumus, Standartus un savu izstrādāto IA metodiku (2.13. attēls). Paši iekšêjie auditori (71,4\% no viņiem) uzskata, ka ir nepieciešamas izmaiņas regulējumā, nosakot IA funkciju kā obligātu. Viens auditors uzskata, ka arī tagad IA ir obligāts, tikai kārtība jānosaka pašiem. Tas kopumā neatbilst IA mērķim un būtībai, kas vairāk ir pārbaude pēc noteiktas kārtības, mēgénot piesaistìt IA prasībām. Cits auditors domā, ka IA var darboties kā līdz šim, pašvaldībām brīvprātīgi ieviešot IA funkciju.

\footnotetext{
${ }^{115}$ Nikolo grupa (2011) Auditoru interviju apkopojums. Nodevums pētijumā "Iekšējās kontroles sistēmas novērtējums un rekomendāciju izstrāde". Rīga, 20 lpp.

${ }^{116}$ Šulca R. (2010) Latvijas pašvaldìbu iekšèjā audita sistèmas attīstības iespējas. Pētījuma kopsavilkums. Jelgava, 131 lpp.
} 


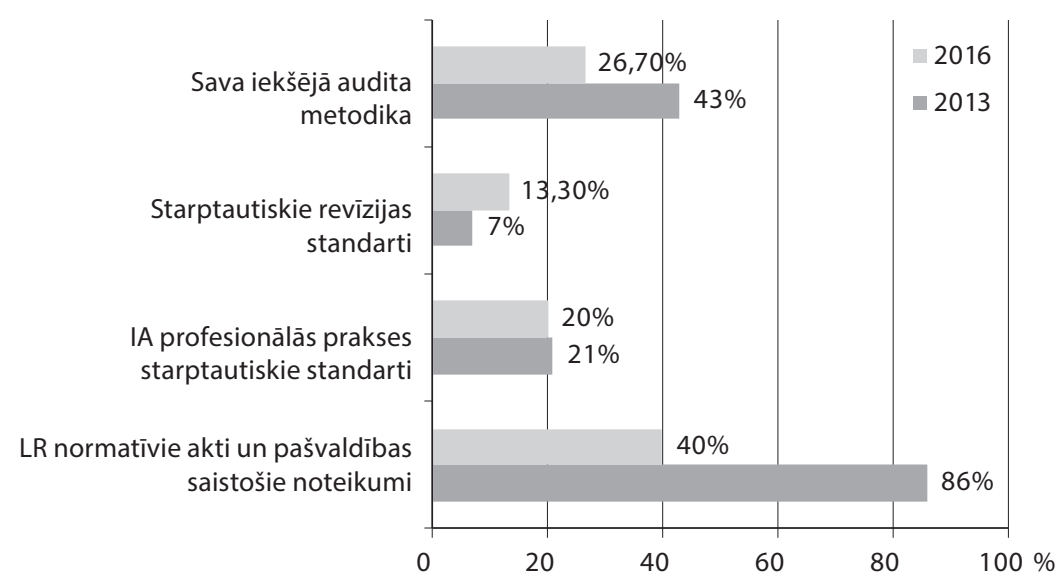

2.13. attēls. Latvijas pašvaldību pamatdokumenti iekšējā audita veikšanai; autores aptaujas dati (2013. un 2016. gads,\%)

Piezīme: respondenti varēja izvēlēties vairākus atbilžu variantus, tāpēc kopsummā atbilžu skaits neveido $100 \%$. Avots: autores veidota diagramma.

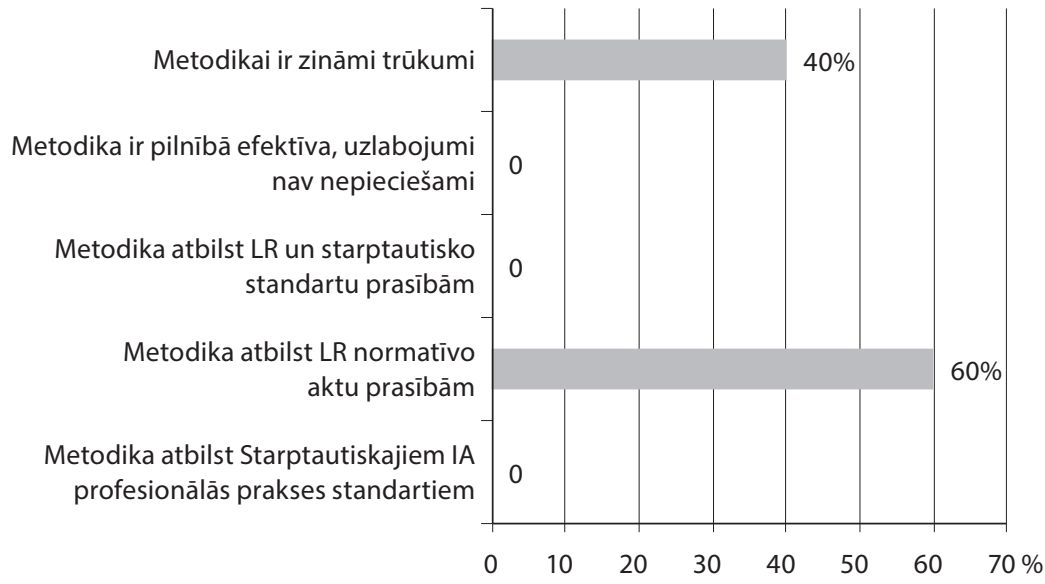

2.14. attēls. Autores aptaujas respondentu atbildes uz jautājumu, kā vērtējat pašreizējo IA metodiku jūsu pašvaldībā (2016, \%)

Avots: autores veidota diagramma.

Daļa pašvaldību iekšējo auditoru savā darbā joprojām piemēro Starptautiskos revīzijas standartus, kas tomēr ir ārējo revidentu pamatdokuments (2.14. attēls). Zīmīgi, ka tikai 58\% no visiem aptaujātajiem pašvaldību iekšējiem auditoriem apmeklē IAI Latvijas nodaļas rīkotos seminārus, kursus, konferences IA jomā, bet pārējie $42 \%$ vispār tos neapmeklē, tikai viens no aptaujātajiem 
auditoriem ir IAI biedrs, kas vēlreiz apstiprina problēmu iekšējo auditoru izglītošanās un kvalifikācijas celšanas jomā (2013. gada aptaujas dati). Savukārt 2016. gada aptaujas dati rāda, ka tikai viens no sešiem iekšējiem auditoriem ir ieguvis iekšējā auditora sertifikātu (neminot, vai tas ir valsts pārvaldes vai starptautiskais sertifikāts). Iekšējo auditoru zināšanas un pieredzi respondenti kopumā vērtē ar pieci (vērtējumu skalā no viens līdz septiņi, kur viens ir slikti un septinini - labi). 2016. gada pētījumā autore konstatējusi, ka pašvaldību auditori uzskata: ir nepieciešamas vienotas apmācības pašvaldību iekšējiem auditoriem (60\%), savukārt 10\% uzskata, ka vajadzīgi garāki kursi, bet 20\% apgalvo, ka trūkst apmācību ārpus Rīgas. Pašvaldỉbu iekšējo auditoru mācību nepietiekamība kā problēma tiek uzsvērta visu sešu respondentu atbildēs, tāpat tiek atzìmēta sertifikācijas nepieciešamība.

Pašvaldību auditoriem pietrūkst zināšanu un prasmju IA un IKS jomā, taču arī kopumā trūkst IT auditēšanas kompetences. Kā risinājums tiek ieteikts pamatā izmantot COSO modeli, kas jau ir integrēts gan Latvijas, gan citu ES dalībvalstu IKS, tomēr būtu jāizmanto arī atsevišķi elementi no citiem iekšêjās kontroles modeliiem. ${ }^{117}$

Pašvaldību iekšējie auditori strādā atbilstoši atškirīgām metodēm, dažās pašvaldībās IA veikšanas metodika vispār nepastāv. Autores veiktajā pētījumā "Latvijas pašvaldības un IA" 2013. gada beigās tika noskaidrots, ka no aptaujātajām 29 pašvaldību IAS 50\% strādā bez metodikas. Uz jautājumu, kā veidojat savu IA metodiku, pašvaldību iekšējie auditori atbildējuši dažādi, atbildes procentuālā sadalījumā ir šādas: 40\% respondentu metodiku veidošanā izmantojuši konsultācijas ar citiem speciālistiem, savukārt $60 \%$ metodikas izstrādājuši paši.

Vairāk nekā puse aptaujāto iekšējo auditoru uzskata, ka izmantotā IA metodika atbilst Latvijas Republikas normatīvo aktu prasībām, savukārt pārējie uzskata, ka metodikai ir zināmi trūkumi. Nevienas pašvaldības metodika neatbilst Standartiem un neviens auditors neapgalvoja, ka metodika ir efektīva un uzlabojumi nav nepieciešami. Tas liecina, ka pašvaldību iekšējie auditori, kritiski vērtējot savus IA veikšanas dokumentus, atzīst, ka tajos ir trūkumi, ko iespējams risināt.

Atbilstoši 2.15. attēlā iekḷautajiem datiem pašvaldību iekšējie auditori galvenokārt veic atbilstības auditus (vidēji $20 \%$ abos periodos), vadības procesu auditus (iepriekšējos gados bijis par 6\% mazāks īpatsvars, bet vidēji 16\% abos periodos) un operatīvos auditus (vidēji $16 \%$ abos periodos). Salīdzinoši mazāka uzmanība tiek veltìta kvalitātes / ISO auditiem (vidēji 4,6\% abos periodos), kas

\footnotetext{
${ }^{117}$ Nikolo grupa (2011) Auditoru interviju apkopojums. Nodevums pētijumā "Iekšējās kontroles sistēmas novērtējums un rekomendāciju izstrāde”. Rīga, 20 lpp.
} 


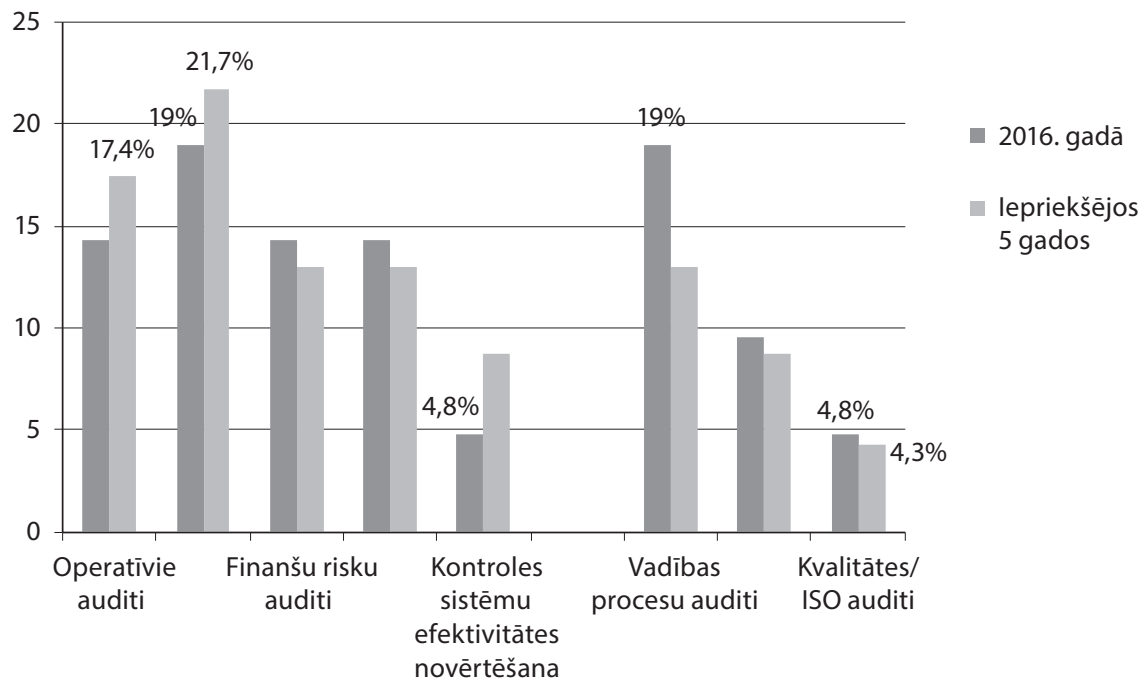

2.15. attēls. Atbildes uz autores aptaujas anketas jautājumu, kādas IA funkcijas tiek veiktas pašvaldībās (2016, \%)

Avots: autores veidota diagramma.

izskaidrojams ar to, ka tikai piecās Latvijas pašvaldībās ir ieviesta kvalitātes vadības sistēma, kas prasa šāda veida auditus. Kontroles sistēmu efektivitātes novērtēšanas auditu īpatsvars vidēji abos periodos bija 6,75\%.

Novērtējot Latvijas pašvaldību IA, respondenti pilnībā piekrīt trīs apgalvojumiem: 1) objektivitāte ir galvenais faktors, lai IA dotu pievienoto vērtību; 2) neatkarība ir galvenais faktors IA pievienotās vērtības radīšanā; un 3) IA rada pievienoto vērtību.

Respondenti pilnībā un daḷēji piekrīt trīs apgalvojumiem: 1) IA ir uzticams; 2) IA ir efektīvs; 3) IA ievēro IAI Ētikas kodeksa prasības.

Respondenti pilnībā vai daḷēji piekrīt apgalvojumiem vai arī nezina, ka 1) IA sniedz sistemātisku IKS efektivitātes novērtēšanu; 2) IA darbojas saskaņā ar Standartiem; 3) IA sniedz sistemātisku pārvaldības procesu efektivitātes novērtēšanu.

Būtiski norādīt, ka mazāk nekā $20 \%$ no auditoriem piekrīt, bet pārējie nepiekrìt apgalvojumam, ka IA ir neatņemama pašvaldības drošas IT un vadības pārvaldības procesa sastāvdaḷa. Tāpat viedokḷi dalās par apgalvojumu, ka IA sniedz sistemātisku efektivitātes un risku vadības novērtēšanu, jo gandrīz $20 \%$ tam nepiekrīt, $45 \%$ piekrìt daḷeji un 35\% piekrìt minētajam apgalvojumam.

Autore apkopojusi IA metodiku analīzi (2015) no septiṇām dažādām Latvijas pašvaldībām (Valmiera, Tukuma novads, Lielvārdes novads, Ķekavas 
novads, Mārupes novads, Daugavpils pilsēta un Jūrmala), kas aptver 31,8\% no visām pašvaldībām, kurās ir ieviesta IAS. Pētījumā konstatēts, ka visas pašvaldības kopumā izmanto valsts pārvaldes normatīvo aktu regulējumu un kādu no valsts tiešās pārvaldes IA metodiskajiem materiāliem. Pašvaldībām ir atšķirīga pieeja iekšèjā audita metodikas izstrādē un nolikumu struktūras veidošanā (2.7. tabula).

Saskan̄ā ar Standartiem IA nolikums ir oficiāls dokuments, kurā noteikts IAS mērķis, pilnvarojums un atbildība. IA nolikumā ir noteikts IAS stāvoklis organizācijā, tai skaitā norādot, kā izpaužas IA vadītāja funkcionālā pakḷautība vadībai, sankcionēta piekḷuve dokumentiem, personālam un fiziskajiem īpašumiem, kas ir būtiski darba uzdevumu izpildei, kā noteikts IA darbïbu apjoms. IA nolikuma galīgo apstiprinājumu sniedz vadība. ${ }^{118}$

Atbilstoši 2.7. tabulas datiem, analizējot IAS nolikumus/kārtības pēc nosaukuma, tika konstatēts, ka divi dokumenti nosaukti par kārtībām un pieci - par nolikumiem, dokumenti apstiprināti laika periodā no 2012. lìdz 2015. gadam. Pašvaldību speciālisti, veidojot IA metodikas, ir pamatojušies uz dažādiem normatīvajiem aktiem, minot trīs dažādus likumus: Valsts pārvaldes iekārtas likumu, likumu "Par pašvaldībām" un Iekšèjā audita likumu. Autore secina, ka izvēelèto pašvaldību dokumenti ir l̦oti atškịingi visos pētāmajos aspektos, kā būtiskākos minot dažādus normatīvos aktus, saskaṇā ar kuriem minētie dokumenti izstrādāti un izdoti, tomēr divos dokumentos trūkst iekšējo auditoru pienākumu un divos dokumentos ienākumi attiecināti uz struktūrvienību kopumā. Arī dokumentu apjomi ir l̦oti atšķirīgi - sākot no 2,5 līdz 10 lappusēm, neskaitot pielikumus. Jāpiebilst, ka tikai divos gadījumos nolikumam/kārtībai pielikumos ir pievienoti dokumentu paraugi.

2.8. tabulā autore ir apkopojusi pētîto pašvaldỉbu metodiku atbilstību IA veikšanas nolikumu/kārtību saskaņā ar MK 09.07.2013. noteikumos Nr. 385 "Iekšèjā audita veikšanas un novērtēšanas kārtība" ietvertajām prasībām par IA veikšanu un novērtēšanu. Vienīgi sadaḷa par IA plāniem ir ietverta visās nolikumos/kārtībās; trijās no septiṇām nav raksturota IA sistēma.

Ar burtiem A, B, C, D, E, F, G tiek apzīmētas pētāmās pašvaldības (Valmiera, Daugavpils pilsēta, Jūrmala, Ḳekavas novads, Lielvārdes novads, Tukuma novads, Mārupes novads).

Kopumā autore secina, ka septiņu Latvijas pašvaldību izvērtētās IA metodikas gan pēc dokumenta veida (nolikums vai kārtỉba), gan pēc būtības un pielietojuma ir ļoti atšḳirīgas un praktiski nav salīdzināmas, jo saskaṇā ar

\footnotetext{
${ }^{118}$ International standards for the professional practice of internal auditing. Available at: http://iai.lv/lv/ standarti [cited 26.01.2012.]
} 
2.7. tabula. Pašvaldību IAS nolikumu/kārtību vispārīgs raksturojums 2015. gadā

\begin{tabular}{|c|c|c|c|c|c|c|}
\hline $\begin{array}{l}\text { Metodika/ } \\
\text { pašvaldība }\end{array}$ & Gads & Nosaukums & Izdots saskaṇā ar & $\begin{array}{l}\text { Vispārīgie } \\
\text { jautājumi }\end{array}$ & $\begin{array}{l}\text { Auditoru } \\
\text { pienākumi, } \\
\text { tiesības, } \\
\text { kompetence }\end{array}$ & $\begin{array}{l}\text { Apjoms, } \\
\text { Ipp. }\end{array}$ \\
\hline A & 2012 & $\begin{array}{l}\text { IA veikšanas } \\
\text { kārtība } \\
\text { pašvaldībā }\end{array}$ & $\begin{array}{l}\text { Valsts pārvaldes } \\
\text { iekārtas likums }\end{array}$ & $\begin{array}{l}\text { Terminu } \\
\text { skaidrojumi }\end{array}$ & Nav norādīts & $\begin{array}{l}10+ \\
\text { pielikumi }\end{array}$ \\
\hline B & 2013 & $\begin{array}{l}\text { Pašvaldības } \\
\text { IA nolikums }\end{array}$ & $\begin{array}{l}\text { Likums "Par } \\
\text { pašvaldībām"; } \\
\text { MK noteikumi "IA } \\
\text { veikšanas kārtība"; } \\
\text { Valsts pārvaldes } \\
\text { iekārtas likums }\end{array}$ & $\begin{array}{l}\text { Skaidrojumi, } \\
\text { pakl̦autība, } \\
\text { pieņemšana } \\
\text { darbā }\end{array}$ & Ir & 4,5 \\
\hline C & 2014 & $\begin{array}{l}\text { IA un revīzijas } \\
\text { veikšanas } \\
\text { kārtība }\end{array}$ & $\begin{array}{l}\text { lekšējā audita } \\
\text { likums; Valsts } \\
\text { pārvaldes iekārtas } \\
\text { likums; likums "Par } \\
\text { pašvaldībām" }\end{array}$ & Vispārīgi & $\begin{array}{l}\text { Nav atsevišksi } \\
\text { izdalīts }\end{array}$ & $\begin{array}{c}5+ \\
\text { pielikumi }\end{array}$ \\
\hline $\mathrm{D}$ & 2015 & $\begin{array}{l}\text { Pašvaldības } \\
\text { audita } \\
\text { darbības } \\
\text { nolikums }\end{array}$ & $\begin{array}{l}\text { Likums "Par } \\
\text { pašvaldībām" } \\
\text { lekšējā audita } \\
\text { likums }\end{array}$ & $\begin{array}{l}\text { Darba vide, } \\
\text { nolikuma } \\
\text { mērksis, IA } \\
\text { likumiskais } \\
\text { pamats }\end{array}$ & Ir & 3,5 \\
\hline$E$ & 2014 & $\begin{array}{l}\text { Pašvaldības } \\
\text { IA nolikums }\end{array}$ & Nav norādīts & $\begin{array}{l}\text { Auditora } \\
\text { kvalifikācija, } \\
\text { pakḷautība, } \\
\text { darba } \\
\text { apjoms } \\
\end{array}$ & Ir & 3 \\
\hline $\mathrm{F}$ & 2014 & $\begin{array}{l}\text { Domes IA } \\
\text { dienesta } \\
\text { nolikums }\end{array}$ & $\begin{array}{l}\text { Valsts pārvaldes } \\
\text { iekārtas likums }\end{array}$ & $\begin{array}{l}\text { Paklautība, } \\
\text { darba } \\
\text { apjoms, } \\
\text { likumiskais } \\
\text { pamats } \\
\end{array}$ & $\begin{array}{l}\text { Nodal̦as } \\
\text { tiesības }\end{array}$ & 2,5 \\
\hline G & $2014 / 2015$ & \begin{tabular}{l|} 
IA un \\
kvalitātes \\
vadības nod. \\
nolikums
\end{tabular} & $\begin{array}{l}\text { Nav norādīts, } \\
\text { apstiprināts ar } \\
\text { domes lēmumu }\end{array}$ & $\begin{array}{l}\text { Nodalas } \\
\text { mērk̦is, } \\
\text { paklautība }\end{array}$ & $\begin{array}{l}\text { Nodaḷas } \\
\text { tiesības un } \\
\text { pienākumi }\end{array}$ & 5,5 \\
\hline
\end{tabular}

Avots: autores veidota tabula.

Ekonomikas skaidrojošajā vārdnīcā ${ }^{119}$ iekḷautajām definīcijām nolikums ir noteikumu kopums par kāda uzņēmuma, organizācijas vadī̌anu, darbības norisi un kontroli, savukārt metodika (kas pēc būtības ir tuvāka kārtībai) ir paṇēmienu kopums un apraksts, kas paredzēts mērkstiecīgai kādu darbu veikšanai.

\footnotetext{
${ }^{119}$ Ekonomikas skaidrojošā vārdnīca (2000) Sastādījis autoru kolektīvs R. Grēviṇas vadībā. Rīga: Zinātne, 702. lpp.
} 
2.8. tabula. Pašvaldību IAS kārtību/nolikumu raksturojums atbilstoši MK 09.07.2013. noteikumiem Nr. 385 "lekšējā audita veikšanas un novērtēšanas kārtība"

\begin{tabular}{|c|c|c|c|c|c|c|c|}
\hline $\begin{array}{c}\text { Pašvaldība / } \\
\text { IA metodika un sadaḷas }\end{array}$ & A & B & C & D & E & $\mathrm{F}$ & G \\
\hline IA sistēma & Nav & $\mathrm{x}$ & $\mathrm{x}$ & $x$ & $x$ & Nav & Nav \\
\hline IA plāni & $x$ & $x$ & $x$ & $x$ & $x$ & $x$ & $x$ \\
\hline IA posmi & $x$ & Nav & $\mathrm{X}$ & Nav & Nav & Nav & Nav \\
\hline $\begin{array}{l}\text { IA izpildes un darba kvalitātes } \\
\text { uzraudzïba }\end{array}$ & $x$ & Daḷēji & $x$ & Dalı̄ēji & Daḷēji & Daḷēji & $x$ \\
\hline $\begin{array}{l}\text { IA struktūrvienības gada } \\
\text { pārskati }\end{array}$ & Nav & Nav & $\mathrm{x}$ & $\begin{array}{c}\text { X } \\
\text { (pusgada } \\
\text { pārskati) }\end{array}$ & $x$ & $x$ & Nav \\
\hline IAS darbības novērtēšana & $\mathrm{Nav}$ & Nav & Nav & Nav & $x$ & Nav & Nav \\
\hline $\begin{array}{l}\text { Pielikumi - dokumentu } \\
\text { veidlapas }\end{array}$ & $x$ & Nav & $x$ & Nav & Nav & Nav & Nav \\
\hline
\end{tabular}

Avots: autores veidota tabula.

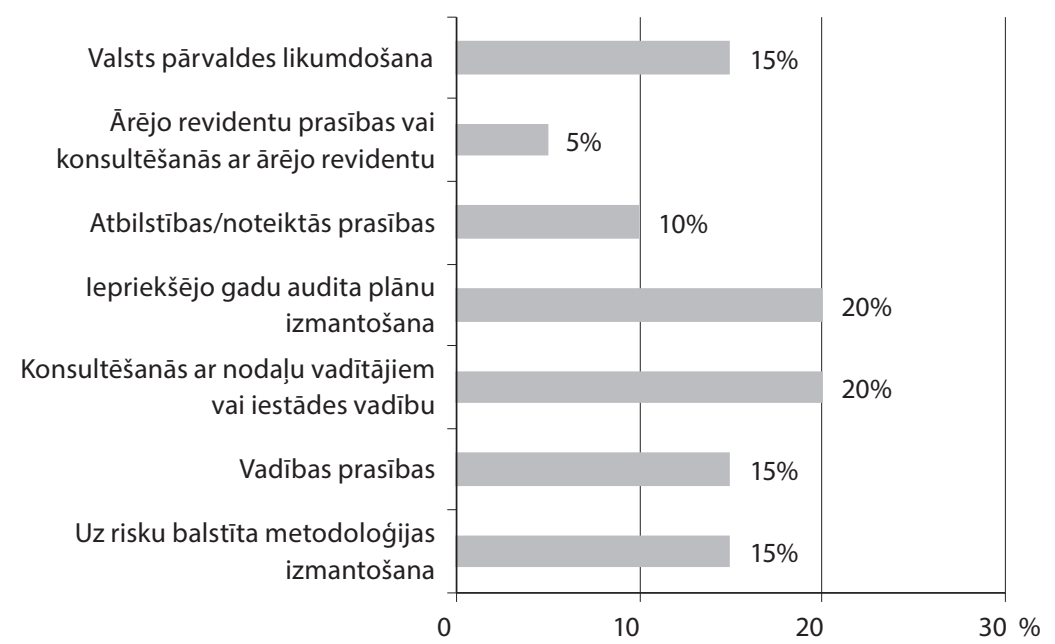

\subsection{6. attēls. Autores aptaujas anketas respondentu atbildes par pašvaldību pieejām, gatavojot IA plānu (2016, \%)}

Avots: autores veidota diagramma. * Respondenti varēja izvēlēties vairāk nekā vienu atbildi.

Gatavojot IA plānus, pašvaldību iekšējie auditori galvenokārt izmanto iepriekšējo gadu IA plānus un/vai konsultēšanos ar nodaļu vadītājiem, iestādes vadību (20\%), par 5\% mazāk tiek izmantotas normatīvo aktu prasības, vadības prasības un uz risku balstītas metodikas, savukārt vismazāk - attiecīgi 5\% un $10 \%$ - iekšējie auditori pašvaldībās izmanto ārējo revidentu prasības vai konsultēšanos ar tiem, kā arī atbilstības noteiktām prasībām (sk. 2.16. attēlu). 


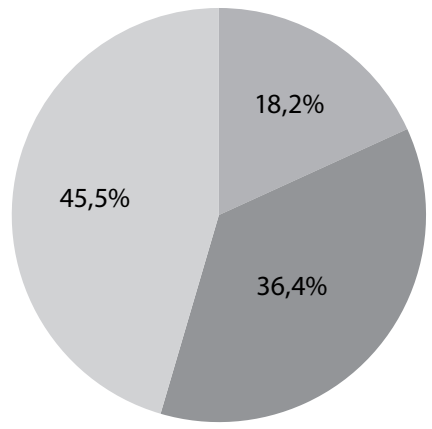

- IA ir l̦oti būtiska nozīme, un pašvaldībās, kur ieviests, tas darbojas efektīvi

IA joprojām nav ieviests daudzās Latvijas pašvaldībās

Likumos trūkst obligāta

IA regulējuma Latvijas pašvaldībās

2.17. attēls. Autores aptaujas respondentu atbildes par IA lomu Latvijas pašvaldībās (2016, \%) Avots: autores veidots attēls.

Vērtējot IA lomu Latvijas pašvaldībās, lielākā daļa respondentu uzskata, ka normatīvajos aktos trūkst obligāta IA regulējuma tajās, savukārt par 9\% mazāk respondentu piekrīt, ka IA joprojām nav ieviests daudzās Latvijas pašvaldībās, un gandrīz viena piektā daļa uzskata, ka IA ir l̦oti būtiska nozīme pašvaldībās, kur tas ieviests un darbojas efektīvi (sk. 2.17. attēlu).

No pozitīvajiem aspektiem jāuzsver, ka pašvaldību iekšējie auditori 2016. gada aptaujā kā motivējošus iekšèjā auditora faktorus ir minējuši labu atalgojumu, darbavietas tuvumu dzīvesvietai un darba atbilstību iegūtajai izglītībai - kopumā $20 \%$ katrs no faktoriem; $40 \%$ minēja faktoru, ka darbs patīk, kas liecina, ka profesijai pašvaldībās ir iespēja attīstīties.

Autore secina, ka IA veikšanas dokumenti pašvaldībām ir ar trūkumiem, tādēl iesaka, ietverot normatīvajos aktos noteiktās vispārējās prasības atbildīgajai ministrijai (FM), izstrādāt IA veikšanas rokasgrāmatu / vadlīnijas, pārṇemot līdzšinējo valsts tiešās pārvaldes pieredzi, proti, izstrādātos MK IA veikšanas noteikumus un IA veikšanas vadlīnijas.

IA pilnveidošanas iespējas Latvijas pašvaldībās autore analizē tālāk 3.2. nodạ̦ā.

Atbilstoši Iekšèjā audita likumam kopīgās valsts pārvaldē auditējamās prioritātes pēc finanšu ministra priekšlikuma nosaka MK. Tādējādi 2012. gadā finanšu ministrs par 2013. gada prioritāti izvirzỉja nepieciešamību veikt pašvaldību finanšu pārskatu sagatavošanas nenodokḷu ieņēmumu un ilgtermiņu ieguldījumu uzskaites jomā uzraudzības un tās IKS darbības auditu. Savukārt 2012. gada 7. decembrī tika izdots Ministru prezidenta V. Dombrovska parakstīts MK rīkojums Nr. 573 "Par kopīgajām valsts pārvaldē auditējamām prioritātēm 2013. gadā" un 2013. gada 26. septembrī rīkojums Nr. 329 "Par pārbaužu veikšanu pašvaldībās”. FM un VARAM iekšêjie auditori 2013. gadā veica pašvaldību 
finanšu pārskatu sagatavošanas nenodokḷu ieņēmumu un ilgtermiņa ieguldījumu uzskaites jomā uzraudzības un tās IKS darbības auditu, kurā izvērtēja:

- kā tiek veikta pašvaldību finanšu pārskatu sagatavošanas uzraudzība nenodokḷu ieņēmumu un ilgtermiņa ieguldỉjumu uzskaites jomā, kā arī novērtēja IKS darbību, identificējot LR VK revīziju ziņojumos sniegto nepilnību cēloṇus;

- pašvaldībām piederošo kapitālsabiedrību darbības pārraudzības pietiekamību.

Saistībā ar Latvijas Lielo pilsētu asociācijas (LLPA) pausto kritiku par pārbaužu veikšanu pašvaldībās, tādējādi neievērojot pašvaldību autonomo kompetenci, VARAM valsts sekretārs Aleksandrs Antonovs 2013. gadā uzsvēra: "Publiskā telpā izskanējusī kritika par VARAM iniciēto pārbaužu veikšanu pašvaldībās ir nekorekta. Uzdevumu îstenot šāda veida pasākumus pašvaldībās VARAM ir devis MK, ar rīkojumu nosakot kopīgās valsts pārvaldē auditējamās prioritātes 2013. gadā.” Šādu pārbaužu veikšanai nepieciešams pilnvarojums, jo pašvaldības nav ne VARAM, ne FM audita apjomā, kā arī atbilstoši likuma "Par pašvaldībām” 5. panta piektajai daḷai pašvaldību darbību pārrauga VARAM. Tāpēc tika sagatavots vides aizsardzības un reǵionālās attīstības ministra rīkojums Nr. 329 "Par pārbaužu veikšanu pašvaldībās”, izveidojot audita grupu, kurai uzdots veikt pārbaudes uz vietas pašvaldībās. "Vēršu uzmanību uz to, ka pārbaudes laikā pašvaldībās uz vietām netiks veikts audits, bet gan iegūta informācija no pašvaldībām, lai audita ietvaros varētu izvērtēt pašvaldību uzraudzības IKS darbību un konstatēt jautājumus, kurus nepieciešams uzlabot valsts pārvaldes līmenī," piebilst A. Antonovs. Auditoru grupa veica pārbaudes 25 pašvaldībās - Viesītes novads, Viḷakas novads, Ventspils novads, Vecpiebalgas novads, Jaunpiebalgas novads, Ropažu novads, Riebiņu novads, Raunas novads, Priekuḷu novads, Pāvilostas novads, Ozolnieku novads, Mērsraga novads, Mārupes novads, Ķekavas novads, Krimuldas novads, Rēzekne un Ventspils, Jēkabpils novads, Dundagas novads, Dobeles novads, Ciblas novads, Beverīnas novads, Baltinavas novads, Alojas novads un Aizkraukles novads. ${ }^{120}$

Galvenie minētā audita pārbaužu dati ir šādi: audita grupa ar VARAM un FM pārstāvjiem; atlasītas 25 pašvaldības, līdz 2013. gada beigām veiktas pārbaudes 23 pašvaldībās, divas (Ventspils un Aizkraukles novads) atteicās sadarboties; katrai pašvaldībai izstrādāts ziņojums ar konstatējumiem un priekšlikumiem; par pārbaužu rezultātiem FM plānoja ziņot 2014. gada informatīvajā ziņojumā par IA darbību ministrijās un iestādēs.

\footnotetext{
${ }^{120}$ Barševska K. VARAM komentārs par pašvaldību pārbaudēm 03.10.2013. Pieejams: http://www.varam. gov.lv/lat/aktual/preses_relizes/?doc=17408 [skatîts 13.08.2015.]
} 
N̦emot vērā lielo darba apjomu un ierobežotos cilvēkresursus, audita kopsavilkums tika sagatavots tikai 2016. gada martā un 2016. gada 8. jūnijā izsūtīts ar vēstuli visām pilsētu un novadu pašvaldībām. Auditori galvenos konstatējumus, secinājumus, ieteikumus un ieteicamos virzienus darbïbas uzlabošanai iedalīja divās daļās:

1) pašvaldību finanšu pārskatu sagatavošanas uzraudzības nenodokḷu ieņēmumu un ilgtermiņa ieguldījumu uzskaites jomā IKS darbība, tai skaitā LR VK revīziju ziņojumos par pašvaldību gada pārskatiem rezultātā sniegto nepilnību cēloṇi; un

2) pašvaldībām piederošo kapitālsabiedrību darbības pārraudzības iekšējās kontroles sistēma. Audita secinājumos norādīts, ka LR VK konstatēto nepilnību cēloṇi ir normatīvo aktu normu neskaidrība, nepietiekama informācija par normatīvo aktu piemērošanu praksē, normatīvo aktu biežās izmaiņas un cilvēciskā faktora kḷūdas risks.

Auditori norādījuši, ka pašvaldībās ir novērojama preventīvo pasākumu nepietiekamība pašvaldību likumīgas un lietderīgas darbības nodrošināšanai, tāpat daudzās pašvaldībās nav veiktas vai nav izsekojamas pārbaudes, kas saistās ar pašvaldību, tās iestāžu, vadītāju, amatpersonu darbībām, budžeta izlietošanu, likumību un lietderību, radot risku, ka pašvaldību darbība netiek nodrošināta likumīgi un efektīvi. Pašvaldību IKS kopumā ir jāuzlabo, lai nodrošinātu sistemātisku, skaidru un vienotu grāmatvedības organizāciju. Kapitālsabiedrību jomā auditori ieteikuši veikt uzlabojumus, veicinot pašvaldību informētību par būtiskajām izmaiņām normatīvajos aktos un par kapitālsabiedrību pārvaldes procesiem, kā arī veicināt normatīvo aktu prasību ievērošanu, izvērtējot iespēju palielināt metodisko atbalstu pašvaldībām līdzdalības izvērtēšanā un regulāru pārvērtēšanu, vidēja termiṇa darbības stratēǵijas izstrādi, kurā ietverti stratēgiskie un finanšu mērḳi, kā arī darbības efektivitāti raksturojoši rezultatīvie rādītāji.

Lai pētìtu IAS ieviešanu pašvaldībās, autore analizē Latvijas pašvaldības, kas atšķiras pēc vairākiem ekonomiskiem kritērijiem, kā galveno kritēriju izvirzot pašvaldību lỉdzekḷus, kas atspoguḷoti bilancē. Atbilstoši likuma "Par pašvaldībām" 76. pantam:

"Pašvaldību ekonomiskais pamats ir manta, tai skaitā finanšu resursi, kas veidojas no: 1) juridisko un fizisko personu nodokḷu maksājumiem pašvaldības budžetā; 2) valsts budžeta dotācijām un mērḳdotācijām; 3) kredītiem; 4) vietējām nodevām un citiem maksājumiem pašvaldības budžetā; 5) pašvaldības budžetā ieskaitāmajiem naudas sodiem; 6) ieņēmumiem no pašvaldības īpašuma apsaimniekošanas un pašvaldības iestāžu saimnieciskās darbības; 7) juridisko un fizisko 
personu brīvprātīgiem maksājumiem noteiktu mērḳu sasniegšanai; 8) citiem ieṇēmumiem."121

Tāpat pašvaldību iespējas ietekmēt vietējās ekonomikas attīstību tiesiskais pamats izriet no likuma "Par pašvaldībām" 15. pantā noteiktajām pašvaldību autonomajām funkcijām. Šāds pamatojums izriet arī no Eiropas vietējo pašvaldību hartas 4. panta pirmās daḷas, kas paredz, ka vietējās pašpārvaldes pilnvaras tiek noteiktas ar konstitūciju vai likumu.

Darbā autore ir veikusi pašvaldību aktīvu un ien̦ēmumu no pamatdarbỉbas (turpmāk - ieņēmumu) analīzi par periodu no 2013. gada līdz 2016. gadam, sīkāk analizējot pašvaldības pēc klasifikācijas attiecībā pret IAS izveidošanas kritēriju 2016. gadā.

Autore izvirza hipotēzi, ka pašvaldību ieņēmumu un aktīvu apjoms ir ietekmējis pašvaldības lēmumu par IAS izveidošanu.

Valsts kases pašvaldību pārskatu datubāzē autore ir izpētījusi katras pašvaldības bilanci un pārskatu par aktīvu un ieṇēmumu rādītājus (noapaḷoti un apkopoti 3. pielikumā), veikusi pašvaldību 2013., 2014., 2015. un 2016. gada ieņēmumu un aktīvu galveno statistikas rādītāju analīzi, grupējot pašvaldības (izslēdzot Rīgas pašvaldību) pēc kritērija - ir vai nav ieviesta IAS, kā arī atsevišķi analizējusi Latvijas statistiskos reǵionus kopā ar lielajām pilsētām, izslēdzot lielo pilsētu pašvaldības (sk. 4. pielikumu). 2.9. tabulā apkopots pašvaldību skaits Latvijas statistiskajos reǵionos, kurās ir vai nav ieviesta IAS uz 2016. gadu. IAS visvairāk ir ieviestas Pierīgas statistiskā reǵiona pašvaldībās (sešās pašvaldībās no 29 pašvaldībām jeb 20,7\% pašvaldību), bet vismazāk Latgales statistiskā reǵiona pašvaldībās (trīs pašvaldībās no 21 pašvaldības jeb 14,3\%). Kurzemē šis rādītājs ir $20 \%$, Zemgalē - $18,2 \%$ un Vidzemē - 15,4\% no visām statistiskā reǵiona pašvaldībām.

Datu analīzes rezultāti par laika periodu no 2013. gada līdz 2016. gadam parāda, ka Latvijas pašvaldībās ar IAS un pašvaldībās bez IAS ieņēmumu un pašvaldību aktīvu apjoms būtiski atškiras. Tā kā Rīgas pašvaldības ieņēmumu un aktīvu apjoms vairāk nekā trīs reizes pārsniedz citu pašvaldību radītājus, autore to izslēdz no tālākiem aprēķiniem (4. pielikuma 1. un 2. tabula). Pašvaldībās, kurās nav bijusi ieviesta IAS, 2013. gadā vidējie ieņēmumi bija 12,37 milj. EUR (aritmētiskais vidējais), pusei pašvald̄̄bu vidējie ieņēmumi bija 8,20 milj. EUR vai mazāki (mediāna); 2014. gadā vidējie ieņēmumi bija 9,30 milj. EUR, pusei pašvaldību vidējie ien̦ēmumi bija 5,90 milj. EUR vai mazāki; 2015. gadā

\footnotetext{
${ }^{121}$ Par pašvaldībām. 19.05.1994. LR likums. Pieejams: http://www.likumi.lv/doc.php?id=57255 [skatìts 23.11.2017.].
} 
vidējie ieņēmumi - 9,46 milj. EUR, pusei pašvaldību vidējie ieņēmumi bija 6,30 milj. EUR vai mazāki, 2016. gadā vidējie ieṇēmumi bija 9,11 milj. EUR, pusei pašvaldību vidējie ieṇēmumi 2016. gadā bija 5,8 milj. EUR vai mazāki.

Tā kā pašvaldības ir dažādas, lietderīgi salīdzināt arī vidējo aktīvu vērtību. Vidējā pašvaldību aktīvu kopsumma 2013. gadā bija 26,68 milj. EUR, pusei pašvaldību vidējo aktīvu kopsumma bija 15,3 milj. EUR vai mazāka; 2014. gadā vidējie aktīvi palielinājās par 1,04 milj. EUR, pusei vidējo aktīvu kopsumma bija 16,4 milj. EUR vai mazāki, 2015. gadā vidējo aktīvu kopsumma palielinājās vēl par 0,83 milj. EUR, salīdzinot ar iepriekšējo pārskata gadu, savukārt 2016. gadā pašvaldību vidējie aktīvi bija 27,69 milj. EUR, bet pusei pašvaldību vidējie aktīvi bija 16,70 vai mazāki.

Pašvaldībās, kurās bija ieviesta IAS, vidējie ieņēmumi no 2013. līdz 2016. gadam bija robežās no 34,02 milj. EUR līdz 47,53 milj. EUR, ieṇēmumu mediānas vērtība bija robežās no 27,50 milj. EUR līdz 35,7 milj. EUR, vidējā aktīvu kopsumma bija robežās no 113,78 milj. EUR līdz 114,35 milj. EUR, aktīvu mediānas vērtība bija robežās no 81,0 milj. EUR līdz 84,4 milj. EUR.

Vidējie ieṇēmumi pašvaldībās, kurās bija ieviesta IAS, laika periodā no 2013. gada līdz 2016. gadam bija aptuveni par 29,42 milj. EUR lielāki un vidējā aktīvu kopsumma aptuveni par 76\% lielāka nekā pašvaldībās, kurās nav ieviesta

2.9. tabula. Latvijas pašvaldību skaits ar un bez IAS (2013-2016)

\begin{tabular}{|c|c|c|c|}
\hline Grupējumi & $\begin{array}{l}\text { Ir ieviesta } \\
\text { IAS }\end{array}$ & $\begin{array}{l}\text { Nav ieviesta } \\
\text { IAS }\end{array}$ & $\begin{array}{c}\text { Kopā } \\
\text { pašvaldības }\end{array}$ \\
\hline Kopā pašvaldības Latvijā & 22 & 97 & 119 \\
\hline Pašvaldības Latgales statistiskajā reǵionā & 3 & 18 & 21 \\
\hline Pašvaldības Zemgales statistiskajā reǵionā & 4 & 18 & 22 \\
\hline Pašvaldības Kurzemes statistiskajā reǵionā & 4 & 16 & 20 \\
\hline Pašvaldības Vidzemes statistiskajā reǵionā & 4 & 22 & 26 \\
\hline Pašvaldības Pierīgas statistiskajā reǵionā & 6 & 23 & 29 \\
\hline Latvijas pašvaldības, izṇemot lielās pilsētas & 14 & 96 & 110 \\
\hline $\begin{array}{l}\text { Pašvaldības Latgales statistiskajā reǵionā, izṇemot } \\
\text { lielās pilsētas (Rēzekne, Daugavpils) }\end{array}$ & 1 & 18 & 19 \\
\hline $\begin{array}{l}\text { Pašvaldības Zemgales statistiskajā reǵionā, } \\
\text { izṇemot lielās pilsētas (Jelgava, Jēkabpils) }\end{array}$ & 2 & 18 & 20 \\
\hline $\begin{array}{l}\text { Pašvaldības Kurzemes statistiskajā reǵionā, } \\
\text { izṇemot lielās pilsētas (Liepāja, Ventspils) }\end{array}$ & 3 & 15 & 18 \\
\hline $\begin{array}{l}\text { Pašvaldības Vidzemes statistiskajā reǵionā, } \\
\text { izṇemot lielās pilsētas (Valmiera) }\end{array}$ & 3 & 22 & 25 \\
\hline $\begin{array}{l}\text { Pašvaldības Pierīgas statistiskajā reǵionā, izṇemot } \\
\text { lielās pilsētas (Jūrmala) }\end{array}$ & 5 & 23 & 28 \\
\hline
\end{tabular}

Avots: autores veidota tabula, pamatojoties uz pašas pētījumu. 
IAS, kas apstiprina hipotēzi, ka lielākajās pašvaldībās (ar lielākiem ieṇēmumiem un aktīviem) ir ieviesta IAS. Jāatzīmē, ka gan pašvaldībās, kurās bija ieviesta IAS, gan pašvaldībās, kurās nebija ieviesta IAS, ieņēmumu un aktīvu summu atšķirības bija l̦oti lielas, ko parāda gan standartnovirze, gan minimālā un maksimālā vērtība (4. pielikuma 1. un 2. tabula).

Analizējot Latvijas statistiskos regionus (4. pielikuma 3.-7. tabula), autore secina, ka visos reǵionos vērojama tā pati sakarība: pašvaldībās, kurās nav ieviesta IAS, vidējās ieņēmumu summas un aktīvu apjoms ir mazāks nekā tajās pašvaldībās, kurās darbojas IAS. Pašvaldībās, kur ir IAS, un pašvaldībās, kur tās nav, ieņēmumu un aktīvu summu atšķirības bija ḷoti lielas, ko parāda gan standartnovirze, gan minimālā un maksimālā vērtība. Autore konstatējusi, ka, skatot statistisko reǵionu grupas bez lielajām pilsētām, situācija ir līdzīga, taču atšķirības ir mazākas, piemēram, Zemgales statistiskajā reǵionā (bez lielajām pilsētām; 4. pielikuma 10. tabula) pašvaldībās bez IAS vidējie ien̦ēmumi 2013.-2016. gadā bija robežās no 8,55 milj. EUR līdz 11,01 milj. EUR, kas ir vidēji par 52\% mazāk nekā pašvaldībās, kurās ir ieviesta IAS.

N̦emot vērā iepriekš konstatēto, autore secina, ka sākotnēji izvirzìtā hipotēze apstiprinās, jo pašvaldību ieņēmumi un aktīvu kopsummas pašvaldībās, kurās nav ieviesta IAS, vidējās ieṇēmumu summas un aktīvu apjoms ir mazāks nekā tajās pašvaldībās, kurās darbojas IAS.

Tā kā pašvaldību kopējo ien̦ēmumu jeb budžetu ietekmējošais faktors ir iedzīvotāju skaits, autore darba 3. nodaḷa iesaka iespējamo risinājumu pašvaldību IA ieviešanai, iedalot pašvaldības pēc iedzīvotāju skaita kritērija.

\section{2. nodal̦as kopsavilkums}

IA valsts tiešajā pārvaldē ir ieviests un darbojas saskaņā ar Latvijas Republikas likumiem un Ministru kabineta noteikumiem. Kopš IA ieviešanas Latvijas valsts tiešajā pārvaldē (no 1999. gada) IA normatīvais regulējums ir attīstījies un pilnveidojies četros secìgos posmos:

1) ieviešana (1999-2002);

2) pārejas periods - statusu maiṇa (2003-2009);

3) starptautisko standartu prasību pārn̦emšana (2010.-2012); un

4) IA sistēmas pilnveidošana no 2013. gada.

Normatīvo aktu izmaiṇas ir ietekmējušas IA procesus un iekšējo auditoru sertifikācijas procesu, kas ar pēdējām izmaiņām tuvināts starptautiskajai sertifikācijas praksei, divu līmeņu sertifikātu aizstājot ar vienu līmeni un 2013. gadā nosakot IA struktūrvienības vadītāja sertifikāciju kā obligātu, lai nodrošinātu plašākas zināšanas un paaugstinātu kompetenci. 
Kopš 2011. gada valsts tiešajā pārvaldē izstrādātas IA veikšanas vadlīnijas, kas ietver gan teorētiskus skaidrojumus, gan praktiskus piemērus ikvienam interesentam par visiem IA posmiem, gan dažādu audita dokumentu paraugus. Sākot ar 2011. gadu, kad sertificēšanās sistēma tika krasi mainìta, sertificēto auditoru skaits līdz 2013. gadam palielinājās, bet pēc tam samazinājās. 2015. gadā iekšējie auditori noslēdza 143 iekšējos auditus un sagatavoja 220 ziņojumus, kuru iesniegšana vidēji tika kavēta $31 \%$ gadijjumu, kas liecina par IA procesa efektivitātes trūkumiem, jo IA gada plāna izpilde, noslēgto IA skaits, IA ziņojumu skaits un to savlaicīgums raksturo IA efektivitāti. Latvijas Republikas izglītîbas sistēmā ir nepietiekama iekšējo auditoru izglītošana, faktiski izglìtošana notiek tikai darba procesā. Jo iekšējo auditoru zināšanas būs plašākas, jo IA rezultāts būs ar lielāku pievienoto vērtību.

Latvijas pašvaldību kontos un kasēs ienāk ievērojama dạ̣a nodokḷu summas, kas ir būtisks iemesls pašvaldību kvalitatìva, neatkarīga un objektīva iekšèjā un ārējā audita nozīmīgajai lomai, lai varētu vērtēt, cik efektīva, racionāla un atbilstoša ir Latvijas pašvaldỉbu ieņēmumu sadale izdevumos un tālāk izdevumu atbilstība paredzamajiem mērķiem. Kaut gan zvērināti revidenti snieguši 101 pozitīvu atzinumu par pašvaldību finanšu pārskatiem, LR VK pēdējos trijos gados konstatējusi būtiskus trūkumus pārskatu sagatavošanā, grāmatvedības uzskaitē un kontroles sistēmās. Lìdz šim nav izdevies mazināt trūkumus IKS, tāpēc darba autore uzskata, ka IA, kas ir viens no galvenajiem instrumentiem, lai ar pārbaudēm un ziņojumiem, ar konsultācijām un ieteikumiem nodrošinātu pašvaldību IKS sakārtošanu, līdz šim nav pienācīgi novērtēts un izmantots.

Latvijas pašvaldību ieņēmumu īpatsvars vispārējās valdỉbas ieṇēmumos pēdējos trīs gadus (2014-2016) bijis vidēji 26,7\%, savukārt pēdējo trīs gadu (2014-2016) pašvaldību izdevumu ipatsvars - $25,8 \%$ no vispārējiem valdības izdevumiem. Pašvaldību iekšējie auditori savā darbā izmanto Latvijas Republikas normatīvos aktus un pašvaldỉbu saistošos noteikumus, Standartus un pašu izstrādāto IA metodiku. $71,4 \%$ no iekšējiem auditoriem uzskata, ka ir nepieciešamas izmaiņas normatīvajos aktos. Pašvaldību iekšējie auditori strādā ar atšķirīgām metodēm, dažās pašvaldībās iekšējie auditori $50 \%$ gadijjumu strādā bez IA metodikas.

Novērtējot Latvijas pašvaldību IA, respondenti pilnībā piekrīt, ka objektivitāte ir galvenais faktors, lai IA dotu pievienoto vērtību; neatkarība ir galvenais faktors IA pievienotās vērtības radīšanā, un IA rada pievienoto vērtību. Atšķirīgi ir respondentu vērtējumi par IA efektivitāti, uzticamību, Ẽtikas kodeksa prasību ievērošanu u. c.

Statistiskās datu analīzes rezultāti (2013-2016) parāda, ka Latvijas pašvaldībās ar IAS un pašvaldībās bez IAS ieṇēmumu un pašvaldību aktīvu apjoms 
būtiski atšķiras. Analizējot Latvijas statistiskos regionus, autore secina, ka vērojama sakarība: pašvaldībās, kurās nav ieviesta IAS, vidējās ieņēmumu summas un aktīvu apjoms ir mazāks nekā tajās pašvaldībās, kurās darbojas IAS. Pašvaldībās, kurās ir ieviesta IAS, laika periodā no 2013. līdz 2016. gadam vidējie ieņēmumi bija aptuveni par 29,42 milj. EUR lielāki un vidējā aktīvu kopsumma aptuveni par 76\% lielāka nekā pašvaldībās, kurās nav ieviesta IAS, kas apstiprina izvirzìto hipotēzi, ka lielākajās pašvaldībās (ar lielākiem ien̦ēmumiem un aktīviem) ir ieviesta IAS. 


\section{LATVIJAS VALSTS TIEŠĀS PĀRVALDES UN LATVIJAS PAŠVALDĪBU IEKŠĒJĀ AUDITA PILNVEIDOŠANAS IESPËJAS}

\section{1. lekšējā audita pilnveidošana valsts tiešajā pārvaldē}

Latvijas valsts pārvades IA ir attīstījies kopš 1999. gada, pilnveidojot normatīvos aktus, iekḷaujot ES un Standartu prasības. Iekšējie auditori kā profesionāḷi ir attīstījuši savu kompetenci un uzkrājuši pieredzi.

Autore piekrīt globālā IAI viedoklim, ka, lai nodrošinātu zināšanu sistemātisku papildināšanu, praktiskās pieredzes attīstība dinamiski mainīgā vidē ir rūpīgi jāuzrauga un nepārtraukti jāanalizēe, lai atklātu būtiskas un svarīgas izpratnes iespējas. Galvenais, kas iekšējiem auditoriem jāmācās profesijā, ir gadiem gūto pieredzi pārveidot atbilstoši pašreizējiem un nākotnes rezultātiem. Lai maksimizētu IA funkciju, neatlaidīgi jāpieņem mūsdienu biznesa vides izaicinājumi. Globalizācija un ātrais izmaiṇu temps sniedz daudzas pārmaiņu iespējas, kas l̦auj IA funkcijai veiksmīgi pilnveidoties dažādos lìmeņos. IA vērtība tiek noteikta ar tās iespēju pozitīvi mainīties un uzlaboties. Tāpat nepieciešama IA profesijas pašreizējo virzienu noteikšana, kas spēj sniegt ieteikumus izmaiñām darbībās, kuras palīdzētu IA:

1) sniegt iestādei augstāko pievienoto vērtību;

2) paredzēt un sasniegt iestādes vajadzības;

3) stratēǵiski pozicionēt IA profesiju ilgtermiṇā. ${ }^{122}$

Iekšējiem auditoriem praktik̦iem ir nepieciešama būtiska un savlaicīga informācija par IA profesijas statusu un labākās iekšējo auditoru prakses ieviešanu pasaulē. Iekšèjie auditori praktiḳi cenšas uzlabot IAD efektivitāti un lietderību.

\footnotetext{
${ }^{122}$ Standards \& Guidance. Available at: https://global.theiia.org/standards-guidance/Pages/Standardsand-Guidance-IPPF.aspx [cited 29.06.2017.]
} 
Autoresprāt, l̦oti atbilstoša ir valsts kontrolieres E. Krūmin̦as atziņa: "Publiskajā sektorā lielāka nozīme ir tam, vai institūcija rīkojusies lietderīgi, efektīvi, likumīgi (..)."123

Lai novērtētu šo jomu, autore 2015. gadā veica ekspertu aptauju par Latvijas valsts tiešās pārvaldes IA efektivitāti un galvenajiem metodikas pilnveidošanu noteicošajiem faktoriem. Anketa nebija anonīma, kas, iespējams, vairākiem ekspertiem kaut kādu iemeslu dēl lika atteikties no piedalīšanās pētījumā, taču kopumā apkopošanai tika saṇemtas sešu ekspertu pilnībā aizpildìtas anketas. Aptaujā piedalijjās un savu viedokli pauda šādi eksperti:

1) FM ES fondu revīzijas departamenta direktore (iepriekš Lauku atbalsta dienesta IAS vadītāja un FM IA departamenta direktore), zvērināta revidente Nata Lasmane;

2) Zemkopības ministrijas IAS vecākā referente Jel̦ena Šokele;

3) LU Biznesa, vadības un ekonomikas fakultātes Finanšu un grāmatvedības nodaļas profesore, kursa "Iekšējais audits" docētāja Inta Brūna;

4) LR VK padomes locekle, Otrā revīzijas departamenta direktore Ilze Grīnhofa;

5) FM IAD IA nodaļas vadītāja Laila Lazdāne;

6) IAI valdes locekle, Latvijas Bankas iekšejjā auditore, pirms tam direktores vietniece Valsts Kases IAD Ingrīda Ivanova.

Visiem ekspertiem pieredze IA jomā ir vairāk nekā 10 gadi, eksperti pārstāv dažādas valsts tiešās pārvaldes iestādes. Pēc anketu apkopojuma iezīmējās vairākas valsts tiešās pārvaldes IA pilnveidošanas jomas.

Autore anketā 14 apgalvojumus par Latvijas valsts tiešās pārvaldes IA adaptējusi no IAIPF 2010. gada pasaules iekšējo auditoru aptaujas Charasteristics of an Internal Audit Activity. Eksperti (3.1. att.):

1) pilnībā vai daḷēji piekrīt apgalvojumam: objektivitāte ir galvenais faktors, lai iekšējais audits dotu pievienoto vērtību (67\% pilnībā piekrīt, 33\% daḷeji piekrīt); viens no ekspertiem uzskata, ka iespējama diskusija par vārdu "galvenais"; IA ir neatkarīgas objektīvas pārliecības radī̌̌ana un konsultēěanas darbības (83\% pilnībā piekrīt, 17\% daḷēji piekrīt);

2) pilnībā vai daḷẹi piekrīt apgalvojumam, ka Latvijas valsts tiešās pārvaldes IA sniedz sistemātisku pārvaldības procesu efektivitātes novērtēšanas pieeju (33\% pilnībā piekrìt, $67 \%$ daḷēji piekrìt); darbojas saskaṇā ar Standartiem (33\% pilnībā piekrìt, 67\% daḷēji piekrīt); sniedz

\footnotetext{
${ }^{123}$ Kubliṇš I. (2016) Grāmatvedim nebūtu jārîkojas pretēji profesionālajai un ētiskajai pārliecībai. Intervija ar Elitu Krūmiṇu, Bilance, Nr. 11/12 (383/384), 2016. gada 1. jūn., 7.-11. lpp.
} 
IA sniedz sistemātisku pārvaldības procesu efektivitātes novērtēšanas pieeju

IA darbojas saskanāar Starptautiskajiem iekšējā audita profesionālās prakses standartiem

IA ievēro IAI Étikas kodeksa prasības

IAI Ētikas kodeksa ievērošana ir galvenais faktors, kas sniedz pievienoto vērtību pārvaldības procesiem

IA sniedz sistemātisku efektivitātes un risku vadības novērtēšanas pieeju

IA ir neatņemama valsts pārvaldes drošas informācijas un vadības pārvaldības procesu sastāvdaḷa

IA ir efektīvs

IA ietekmē svarīgu finanšu notikumu, risku un IK novērtējumu

IA ir uzticams

IA sniedz sistemātisku pieeju IK efektivitātes novērtēšanai

IA rada pievienoto vērtību

Neatkarība ir galvenais faktors iekšējā audita pievienotās vērtības radīšanā

IA ir neatkarīgas objektīvas pārliecības radīšana un konsultēšanas darbības

Objektivitāte ir galvenais faktors, lai IA dotu pievienoto vērtību

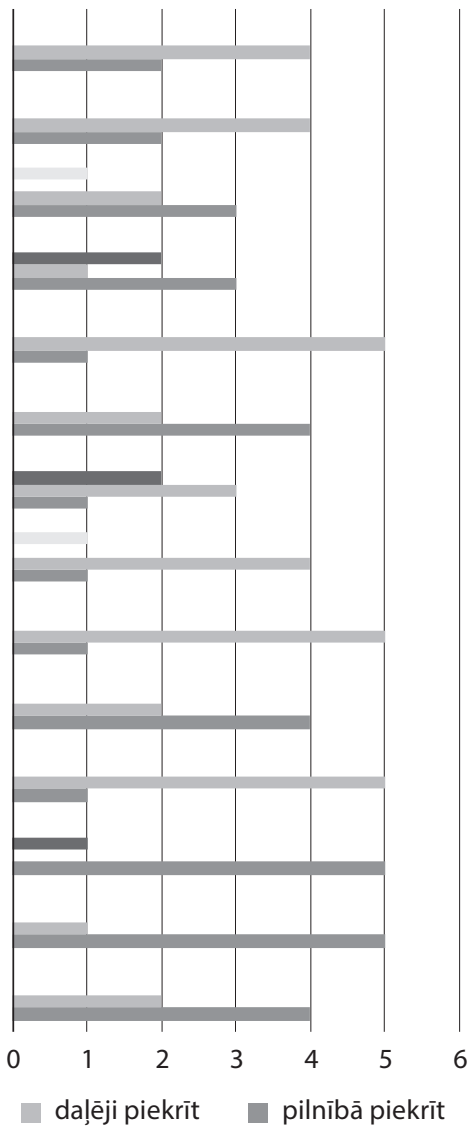

nezina $\square$ nepiekrīt

daḷejii piekrīt

pilnībā piekrīt

\section{1. attēls. Ekspertu vērtējumi par Latvijas valsts tiešās pārvaldes IA vērtēšanas kritērijiem (2015)}

Avots: autores veidota diagramma.

sistemātisku efektivitātes un risku vadības novērtēšanas pieeju (17\% pilnībā piekrìt, 83\% daḷēji piekrīt); ir neatņemama valsts pārvaldes drošas informācijas un vadības pārvaldības procesu sastāvdaḷa (67\% pilnībā piekrīt, 33\% dal̦ēji piekrīt); ir uzticams (17\% pilnībā piekrìt, 83\% dal̦ēji piekrīt); sniedz sistemātisku pieeju iekšējās kontroles efektivitātes novērtēšanai (67\% pilnībā piekrīt, 33\% daḷēji piekrīt); rada pievienoto vērtību (17\% pilnībā piekrīt, 83\% dậ̄ēii piekrīt);

3) pilnībā vai daḷeji piekrìt vai nepiekrīt apgalvojumam Latvijas valsts tiešajā pārvaldē: IAI Ētikas kodeksa ievērošana ir galvenais faktors, kas sniedz pievienoto vērtību pārvaldības procesiem (67\% pilnībā piekrīt, $17 \%$ dalẹji piekrīt un 33\% nepiekrît); IA ir efektīvs (17\% pilnībā piekrìt, 
50\% daḷeji piekrìt un 33\% nepiekrìt); neatkarība ir galvenais faktors IA pievienotās vērtības radīšanā (83\% pilnībā piekrīt, 17\% nepiekrīt);

4) pilnībā vai daḷeji piekrīt apgalvojumam vai nezina, ka Latvijas valsts tiešās pārvaldes iekšējais audits ievēro IAI Ėtikas kodeksa prasības (50\% pilnībā piekrìt, 33\% daḷēji piekrìt un 17\% nezina); ietekmē svarīgu finanšu notikumu, risku un iekšējās kontroles novērtējumu (17\% pilnībā piekrìt, $17 \%$ daḷeji piekrìt un $67 \%$ nezina).

No apkopotajām atbildēm autore secina, ka ekspertu viedoklị ir samērā atšķirīgi, ņemot vērā vairākus faktorus (pārstāvētā iestāde, pieredze, ieņemamais amats), taču aptuvena vienprātîba valsts tiešās pārvaldes IA ekspertu vērtējumā ir 83\% ekspertu, kuri pilnībā piekrīt apgalvojumam, ka neatkarība ir galvenais faktors IA pievienotās vērtības radīšanā un ka IA ir neatkarīgas objektīvas pārliecības radīšana un konsultēšanas darbības, kas ir vairāk teorētiski jautājumi. Tāpat 83\% ekspertu daḷeji piekrīt apgalvojumiem, ka Latvijas valsts tiešās pārvaldes IA sniedz sistemātisku efektivitātes un risku vadības novērtēšanas pieeju, ka IA ir uzticams un rada pievienoto vērtību.

Autore uzskata, ka svarīgs ir ekspertu "nepiekrìt apgalvojumam" vērtējums, jo 33\% ekspertu uzskata, ka IA nav efektīvs. Uz jautājumu, kā eksperti vērtē pašreizējo IA metodiku valsts tiešajā pārvaldē, viņu viedokḷi dalās (3.2. attēls). Pieci eksperti uzskata, ka metodika Latvijas valsts tiešajā pārvaldē atbilst gan Standartiem, gan Latvijas Republikas normatīvajiem aktiem, savukārt divi eksperti uzskata, ka metodika ir veidota atbilstoši Latvijas Republikas normatīvajiem aktiem, bet viens eksperts uzskata, ka metodikā ir zināmi trūkumi (3.2. attēls).

Apkopojot ekspertu viedokḷus par IA metodiku, autore secina, ka valsts pārvaldē iekšējo auditoru vidū viedokḷi dalās - augstākā līmeņa vadītāji uzskata, ka ir vērojamas metodikas izmantošanas problēmas, savukārt pārējie eksperti norāda atsevišķus trūkumus, kas kopumā liecina par to, ka ir nepieciešami zināmi uzlabojumi FM veikto pārbaužu metodikā vai arī "jāveic korekcijas" darbinieku attieksmē pret veicamajiem pienākumiem.

Uz jautājumu, kā eksperti vērtē IA lomu šobrīd Latvijas valsts tiešajā pārvaldē, pieci no sešiem ekspertiem ir vienisprātis, ka IA loma vēl joprojām netiek pienācīgi novērtēta, tā nav ieviesta un nefunkcionē daudzās tiešās un pastarpinātās valsts pārvaldes institūcijās.

Autore secina: kopumā IA joprojām netiek pienācīgi novērtēts, pie kā dal̦ejji vainojami arī paši iekšējie auditori. Tāpat būtiska loma ir iestādes vadìtāja pienācīgai izpratnei par IA funkciju îstenošanu gan paša vadītajā iestādē, gan kopumā valsts pārvaldes IA jomā. Jāuzsver, ka noteikti viens no vissvarīgākajiem faktoriem ir paša iekšèjā auditora kvalifikācija, kompetence un attieksme pret IA uzdevumu kvalitatīvu izpildi. 


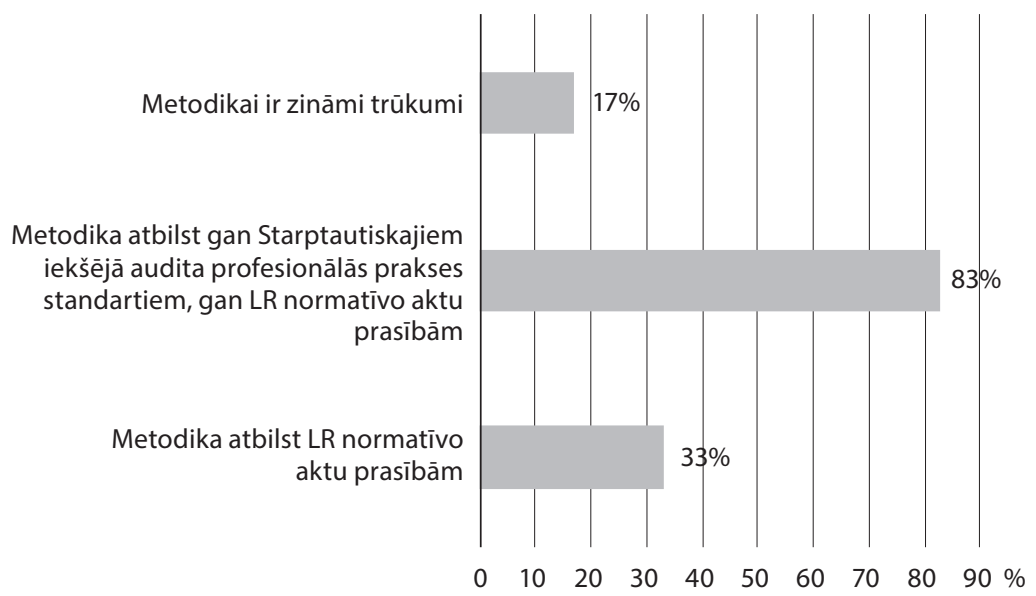

\section{2. attēls. Ekspertu vērtējums par valsts tiešās pārvaldes IA metodiku (2015)}

Avots: autores veidota diagramma.

* Ekspertiem bija iespēja izvēlēties vairākus atbilžu variantus, tāpēc kopējo atbilžu skaits ir vairāk nekā 100\%.

Lai risinātu minētās problēmas, lietderīgi īstenot šādus ieteikumus: turpināt FM organizētās regulāras tikšanās un diskusijas gan IAS darbiniekiem, gan tikai IAS vadītājiem; pašiem iekšējiem auditoriem vairāk iesaistīties IAI rīkotajos pasākumos, diskusijās; iespēju robežās regulāri izglītot IAS darbiniekus IA pienācīgā popularizēšanā; rīkot regulāras tikšanās ar iestāžu un ministriju vadītājiem, veicinot vadītāju pienācīgu izpratni par IA funkciju îstenošanu. Svarīgs uzdevums būtu organizēt kvalifikācijas celšanas mācību kursus sadarbībā ar Latvijas augstākajām mācību iestādēm.

Ekspertu viedoklis par Latvijas Republikas ministriju un iestāžu IA problēmām ir atšksirīgs:

1. Iekšējo auditoru zināšanas un pieredze nav pietiekama. Autores secinājums - ekspertu viedokḷi arī šajā jautājumā dalās. Trīs eksperti piekrīt, divi dal̦ēji piekrìt un viens nepiekrìt apgalvojumam, ka iekšējo auditoru zināšanas un pieredze nav pietiekama. Kopumā autore jau iepriekšējos pētijumos ir konstatējusi, ka auditoru zināšanas un pieredze, kas savukārt atkarīga no darbinieku mainības, būtiski ietekmē IA kvalitāti valsts tiešajā pārvaldē. Ekspertu viedokḷ̆os skaidri saskatāma galvenā problēma - atalgojuma nesabalansētība. Autore uzskata, ka tas kopumā būtiski ietekmē auditora motivāciju iegūt papildu zināšanas par saviem lìdzekḷiem, ja darbavieta to nevar nodrošināt, bet auditoram ir nepieciešamas papildu zināšanas, ņemot vērā gan viņu iepriekšējo izglîtību, pieredzi, gan personiskās ìpašibas un prasmes. Lai risinātu šo 
problēmu, viens no ekspertiem ir ierosinājis veidot IA darbinieku motivācijas programmu, kas l̦autu sabalansēt IA darbinieku atalgojumu visā valsts pārvaldē, kā arī sistēmu, kurā darbinieki daļu apmācību sedz no saviem lìdzekliem.

2. Iekšèjo auditoru skaits turpina samazināties, ir apgrūtināta plānu izpilde. Analīze rāda, ka eksperti arī šo jautājumu vērtē dažādi, to skaidrojot gan ar kopējo valsts ekonomisko situāciju, gan politisko ietekmi, ko autore uzskata par svarīgu. Valsts pārvaldē ministrijās un iestādēs atalgojumi ir samērā atšķirīgi, n̦emot vērā darbinieku grupas, kategorijas, kā arī minimālās un maksimālās summas atbilstoši MK noteikumiem Nr. 66 "Noteikumi par valsts un pašvaldību institūciju amatpersonu un darbinieku darba samaksu un tās noteikšanas kārtību”. Tāpat autore pilnībā piekrìt viedoklim, ka auditoru skaits ne vienmēr ietekmē plānu izpildi, jo l̦oti būtiska ir IA plānošana un efektivitāte, kas ir neatṇemamas jebkura procesa sastāvdaļas. IA liela nozīme ir arī katra darbinieka individuālajām īpašībām un prasmēm strādāt ar liela apjoma informāciju. Ieteikums: IAS vadītājiem, veicot IA plānošanu un paaugstinot plānu izpildi, kā arī sadalot darba pienākumus, pievērst uzmanību darba efektivitātei un noteikt apjoma darbu atbilstoši katra darbinieka individuālajām spējām, tā veicinot darbinieku motivāciju darbam valsts pārvaldē.

3. Zems IAS novērtējums - struktūrvienības darbojas ar būtiskām nepilnībām. Autore piekrīt ekspertu viedoklim, ka zemais IA struktūrvienību novērtējums - audita struktūrvienību darbošanās ar būtiskām nepilnībām - ir vērojams tikai atsevišķās iestādēs un ministrijās. Taču, ja valsts pārvaldē ir šādi gadījumi, tad ir jautājums, vai var apgalvot, ka ministriju un iestāžu IA darbības pārskati liecina par IA sekmīgu darbību? Ja teorētiski pieņemam, ka dažas IAS darbojas izcili, dažas teicami, citas labi un vairākas vāji vai ḷoti vāji, tad kopumā rezultāts, protams, ir pozitīvs!

4. IAS darbības novērtēšanu veic nepraktizējoši iekšējie auditori. Ekspertiem arī šajā jautājumā nav vienprātības: četri eksperti piekrīt, bet viens apgalvo pretējo, ka IAS darbības novērtēšanu veic nepraktizējoši iekšējie auditori. Autore pilnībā piekrīt ekspertu viedoklim, ka IA darbība tiek vērtēta galvenokārt no teorētiskā aspekta, iespējams, nepietiekami novērtējot IA veikšanas praksi. Problēmas risināšanai iesakāms FM izvērtēt iespēju IA struktūrvienību darbības novērtēšanas darba grupā iekļaut dažādu sektoru IA speciālistus ekspertus, kas pārstāvētu gan valsts pārvaldi, gan privāto sektoru, gan banku sektoru, bet, veicot novērtējumu, akcentēt IA ìstenošanas praksi. 


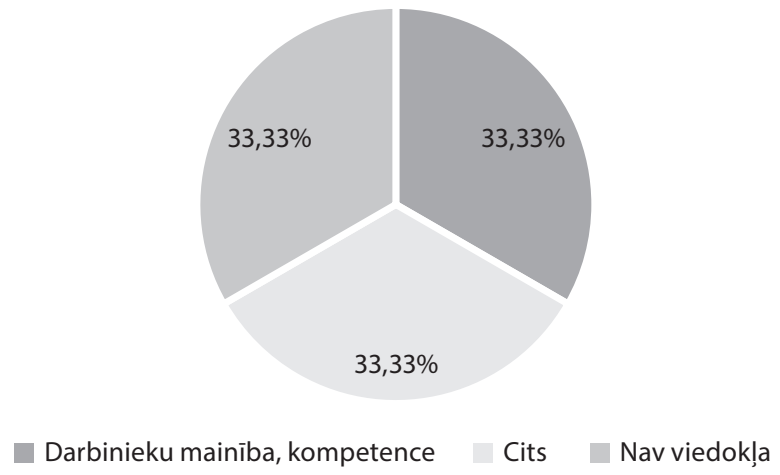

3.3. attēls. Ekspertu viedoklis par trūkumu iemesliem dažu IA struktūrvienību darbā

Avots: autores veidots grafiks, pamatojoties uz autores veikto ekspertu aptauju.

Uz jautājumu, kāpēc Latvijas valsts tiešajā pārvaldē - Ārlietu ministrijā, Satiksmes ministrijā un Korupcijas novēršanas un apkarošanas birojā - jau vairākus gadus ir trūkumi IAS darbā, ekspertu viedokḷi dalās līdzīgi (sk. 3.3. attēlu).

Divi eksperti uzskata, ka galvenais iemesls ir darbinieku mainiba un darbinieku kompetences trūkums, divi eksperti neizsaka savu viedokli, savukārt pārējiem diviem ekspertiem ir šāds viedoklis:

- visdrīzāk viss ir atkarīgs no vadītāja, auditors nevar darboties bez vadības atbalsta;

- Latvijas valsts pārvaldē trūkst pieredzējušu iekšējo auditoru, kas gribētu strādāt valsts pārvaldē. Iemesls - slikta motivācija. Vadība neprot šo rìku izmantot. Latvijas valsts pārvalde kopumā ir tendēta uz korektīviem, nevis preventīiem pasākumiem.

Izvērtējot ekspertu izteikumus, var secināt, ka kopumā valsts tiešās pārvaldes iestāžu un ministriju IA sistēmas nepilnību svarīgs iemesls ir neatbilstoša darbinieku motivācija attīstìties un izglìtoties, kas tālāk neveicina darbinieku kompetenci, ietekmē kadru mainību un arī dažādu konfliktsituāciju veidošanos. Situācijas uzlabošanai svarīgi īstenot autores izvirzìto priekšlikumu - FM kopumā kompleksi risināt situāciju, sākot ar iekšējo auditoru profesijas standartu ieviešanu valstī, kas noteiktu stingru sertifikāciju un auditoru specializēšanos konkrētās jomās: IT, personālvadība, finanses un budžets, grāmatvedības uzskaite, projekti u. c.

Jautājumā par to, ka IA padome jau vairākus gadus aicina risināt IT auditu jautājumus un problēmas, bet, lai gan arvien pieaug IT riski ministriju un iestāžu darbībā, situācija līdz 2015. gadam nav mainījusies, eksperti izteikuši samērā atšḳirīgus viedokḷus un komentārus. 
Autore secina, ka situācija IT jomā valsts tiešajā pārvaldē nav sakārtota, par ko liecina 2015. gadā sāktais IT audits. Stāvokḷa uzlabošanai autore FM piedāvā šādu risinājumu - valsts tiešās pārvaldes IT audita rezultāti jāizvērtē neatkarīgai IT speciālistu komisijai un pēc nepieciešamības jāveic atkārtots IT audits, pieaicinot ekspertus. Kopumā jāpiekrīt līdzīgiem apgalvojumam, kas pausti vairākos informatīvajos ziņojumos par pēdējo gadu IA sistēmu valsts pārvaldē - sistēma kopumā darbojas, taču ir nepieciešami atsevišķi uzlabojumi trūkumu novēršanai.

Situācijas pilnveidošana iespējama, ja iekšējie auditori turpinātu darbu pie tālākas attīstības, popularizējot iekšējo auditoru profesiju, kas ir viens no globālā IAI mērkiiem. Savukārt struktūrvienību un iestāžu vadītājiem, nodrošinot darbinieku izglītošanās, profesionālās pilnveides un sertifikācijas iespējas, vajadzētu motivēt iekšējos auditorus palikt strādāt valsts pārvaldē, kā arī rūpēties par IA sistēmas pilnveidošanu kopumā.

\subsection{Latvijas pašvaldību iespējamie risinājumi iekšējāa audita jomā}

\subsection{1. lekšējā audita nepieciešamība}

Iepriekšèjā nodạ̧ā pētītā pašvaldību situācija liecina par nopietniem trūkumiem IKS, sākot ar vadītāju un finanšu speciālistu nepilnīgu izpratni par normatīvo aktu prasībām un beidzot ar darbinieku apzinātām vai neapzinātām kḷūdām un krāpšanos.

Latvijas pašvaldības ir būtiska Latvijas kopējās valsts pārvaldes daḷa. Atbilstoši 2015. gada CSP datiem no 2010. gada līdz 2016. gadam Latvijas pašvaldībās un pašvaldību padotības iestādēs strādājuši par aptuveni no $33000 \mathrm{līdz}$ 42000 darbinieku vairāk nekā Latvijas valsts tiešajā pārvaldē - ministrijās, centrālās valsts iestādēs un to padotības iestādēs (sk. 3.4. attēlu). Interesanti, ka pēdējos trīs gados darbinieku skaits ir bijis nemainīgs, izņemot 2016. gadu, kad ministriju un valsts iestāžu darbinieku skaits palielinājās par vienu tūkstoti.

Jebkura Latvijas pašvaldība ir vistuvāk mūsu valsts iedzīvotājiem, un no pašvaldību pakalpojumu kvalitātes un efektivitātes ir atkarīgs vērtējums par valsts pārvaldes darbību kopumā.

Procentuāli konsekventais pašvaldību darbinieku skaita pārsvars pār kopējo darbinieku skaitu ministrijās, centrālajās valsts iestādēs un to padotības iestādēs jeb valsts tiešajā pārvaldē visos gados liecina, ka pašvaldību un to iestāžu darbinieku skaits ir palielinājies par 4,23 procentpunktiem laika periodā no 2010. gada lìdz 2016. gadam (3.4. attēls). 


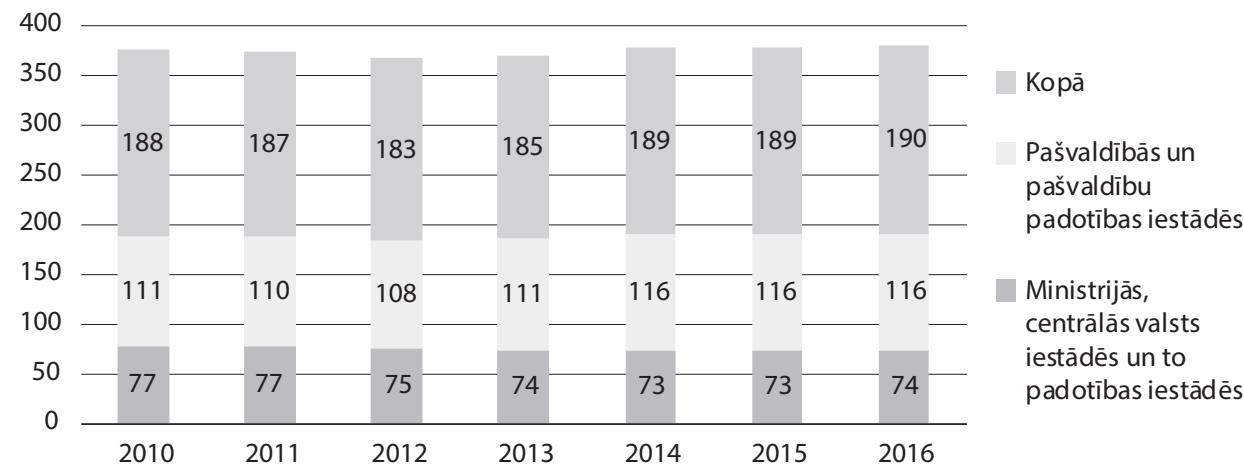

3.4. attēls. Darbinieku skaits pašvaldībās un valsts tiešajā pārvaldē, tūkst. darbinieki (2010-2016)

Avots: autores veidota diagramma, pamatojoties uz Centrālās statistikas pārvaldes datiem.

Jau 2005. gadā SIGMA eksperti norādỉja:

"IA vietējām pašvaldībām un valsts uzṇēmumiem normatīvos aktos netiek pieprasìts, bet tam vajadzētu būt. Kad normatīvie akti to noteiks, standarti, rokasgrāmatas un instrukcijas, ko izstrādāja IAD [FM - aut. piezīme] par IA, būtu jāpiemēro arī šajās jomās. Jāpadomā, kā paplašināt IAD un IA padomes lomu šajās jomās. To varētu izveidot ar politikas dokumenta palīdzību un ietvert tajā iekšējās kontroles, finanšu pārvaldības un pārskatu sniegšanas jautājumus, kā arī IA kārtību - tā, lai nodrošinātu maksimālu sistēmas kvalitāti un efektivitāti, tajā pašā laikā atbrīvojoties no visas nevajadzīgās dublēšanās."124

Autore uzskata - kamēr normatīvajos aktos nebūs noteiktas pašvaldību IA ieviešanas prasības, nekas pats no sevis neattīstīsies un nenotiks.

Pētijjuma laikā autore ir apkopojusi Valsts kontrolieru I. Sudrabas un E. Krūmiņas viedokḷus par IA nepieciešamību Latvijas pašvaldībās:

I. Sudraba (2012):

"LR VK kopumā veiksmīgi sadarbojas gan ar valsts iestāžu, gan pašvaldību iekšējiem auditoriem. Iekšējo un ārējo auditoru sadarbību nosaka 610. starptautiskais revīzijas standarts "Iekšējo revidentu darba izmantošana". Saistībā ar IA attīstỉbu pašvaldībās būtu rūpīgi izvērtējams, vai katrā pašvaldībā būtu jāievieš un jāuztur IA funkcija, vai tas ir ekonomiski pamatoti. IA funkcija ir efektīvs veids, kā pilnveidot un

\footnotetext{
${ }^{124}$ SIGMA ekspertu palīdzība valsts iekšejjā audita sistēmai Latvijā. SIGMA ekspertu sagatavotais detalizētais ziņojums. 2005. gada aprīlis, 16. lpp.
} 
nodrošināt iekšējo kontroli, tomēr tas ir saistīts ar papildu izmaksām. Turklāt atbilstoši likuma "Par pašvaldībām" 71. pantam: "Finanšu revīziju veikšanai, revīzijas pārskatu sagatavošanai un atzinuma sniegšanai par saimnieciskā gada pārskatu dome ne retāk kā reizi gadā uzaicina auditorfirmas vai zvērinātus revidentus, kuru darbu apmaksā no attiecīgās pašvaldības budžetā paredzētajiem lìdzekḷiem un kuru sniegtais atzinums var dot pašvaldībām zināmu pārliecību par iekšèjās kontroles sistēmas darbību." 125

E. Krūmiņa (2014):

"Iekšèjais audits varētu būt viens no IKS posmiem. LR VK, veicot finanšu, likumības un lietderības revīzijas pašvaldībās, līdz šim nav izmantojusi IA veikto darbu, bet gan vērtējusi, vai pašvaldība ir nodrošinājusi IKS darbïbas pamatprasības, kas ir noteiktas MK 2012. gada 8. maija noteikumos Nr. 326 "Noteikumi par IKS tiešās pārvaldes iestādēs" 2. punktā:

1) efektīvu, lietderīgu un ekonomisku pašvaldības darbību atbilstoši tās kompetencei, izvirzìtajiem mērķiem, uzdevumiem un pieejamajiem resursiem;

2) pašvaldības darbību iedzīvotāju interesēs, nodrošinot labu pārvaldību;

3) pašvaldību darbỉbu atbilstoši normatīvajos aktos noteiktajai kompetencei;

4) iespējamo korupcijas un interešu konflikta izveidošanās risku novēršanu;

5) mantas un finanšu līdzekḷu izšḳērdēšanu, neefektīvas un nelietderīgas izmantošanas novērtēšanu;

6) piel̦auto kḷūdu savlaicīgu identificēšanu un novēršanu un nepieciešamo uzlabojumu veikšanu;

7) savlaicīgas, ticamas finanšu vai vadības informācijas iegūšanai.

Savukārt veicot revīzijas ministrijās un centrālajās valsts iestādēs, LR VK revidenti aktīvi sadarbojas ar iestāžu IAS. IA veiktais darbs tiek izmantots izpratnes gūšanai par iestādi un revīzijā tiek novērtēta arī iespēja paļauties uz IA veikto darbu."126

${ }^{125}$ Sudraba I. Par diskusiju LU doktorantūras skolā. E-pasts 2012. gadā ar viedokli par iekšèjā audita ieviešanu Latvijas pašvaldībās.

${ }^{126}$ Par informācijas sniegšanu. LR VK 12.11.2014. vēstule Nr. 11.3.5.4.2/156 I. Faitušai. 
No iepriekš minētā autore secina, ka valsts kontrolieri nav pilnībā gatavi paļauties uz IA viedokli arī valsts tiešās pārvaldes iestādēs, savukārt pašvaldībās vispār nav izmantojuši IA darbu.

2015. gada LR VK ziņojumāā ${ }^{127}$ minēts, ka pašvaldībās, tāpat kā iepriekšèjos gados, ir konstatētas gan fundamentālas kḷūdas ilgtermiṇa ieguldījumu uzskaitē, gan finanšu līdzekḷu piesavināšanās gadījumi. Revidentu ieskatā, minētos trūkumus izraisa dažu pašvaldību vadītāju nespēja nodrošināt atbilstošu iekšējās kontroles vidi, nevēlēšanās rīkoties atbilstoši normatīvo aktu prasībām vai nepilnības normatīvajos aktos, kā arī dažos gadījumos zvērinātu revidentu darbs. LR VK 2014. gadā nevarēja sniegt viedokli par pašvaldību gada pārskata daḷā iekḷautajiem aktīviem un pasīviem pārskata gada sākumā 10,6 milj. EUR vērtībā un pārskata gada beigās 11,6 milj. EUR vērtībā, ieṇēmumiem 6,4 milj. EUR vērtībā un izdevumiem 6,3 milj. EUR vērtībā.

Pārbaudēs revidenti konstatējuši krāpšanas un kḷūdu izraisītas neatbilstības, kā rezultātā fiziskajām personām nelikumīgi pārskaitīti pašvaldības naudas līdzekḷi, nav nodrošināta iekasēto naudas līdzekḷu saglabāšana, pārbaudēs konstatēta nepamatota ilgtermiņa ieguldījumu vērtỉbu palielināšana vairāku miljonu apmērā.

Pašvaldību grāmatvedības uzskaite nav organizēta tā, lai nodrošinātu līdzekḷu uzrādīšanu saskaņā ar attaisnojuma dokumentiem un darījuma ekonomisko būtību.

2016. gada LR VK ziņojumā minēts, ka pašvaldību gada pārskatu dạ̦ā uzrādìtā informācija nav patiesa un salīdzināma:

1) zemes, èku un būvju vērtība gada sākumā ir nepamatoti palielināta vismaz par 77 milj. par pamatlīdzekḷu izveidošanu un nepabeigto būvniecību, jo pārskata gada sākumā bilances posteņa vērtība ir nepamatoti samazināta vismaz par 386,5 tūkst. EUR;

2) biolog̣isko un pazemes aktīvu vērtība ir nepamatoti palielināta vismaz par 64,4 tūkst. EUR;

3) ilgtermiņa finanšu ieguldījumu vērtība pārskata gada sākumā ir nepamatoti palielināta par 286 tūkst. EUR;

4) viena pašvaldība saistības 321,9 milj. EUR apmērā ir uzrādījusi pretēji darïjuma ekonomiskajai būtībai kā ilgtermiņa parādu piegādātājiem un darbuzñēmējiem un pārskata pielikumā nav uzrādījusi aizṇēmumu 571,5 milj. EUR apmērā.

\footnotetext{
${ }^{127}$ LR 2015. gada pārskatu par valsts budžeta izpildi un par pašvaldību budžetiem, LR VK, Rīga, 2016. gada 15. septembris. Pieejams: http://www.lrvk.gov.lv/uploads/reviziju-zinojumi/2015/2.4.134_2015/3.3.-revizijas-zinojums-sgp-2015_publicesanai.pdf [skatīts 27.01.2017.]
} 
Neatbilstošas iekšèjās kontroles vides - IKS - neesības dēḷ pašvaldībās vai tās neefektivitātes rezultātā tiek piel̦autas kḷūdas un normatīvajiem aktiem neatbilstoša grāmatvedības uzskaites kārtošana, kas būtiski ietekmē pašvaldību gada pārskatos un saimnieciskā gada pārskatā uzrādītās informācijas kvalitāti.

Valsts pārvaldes iekārtas likuma 17. panta otrā daļa un 30. panta otrā daļa un likuma "Par budžetu un finanšu vadību" 46. panta pirmā daļa nosaka to, ka pašvaldību vadītāji:

- organizē iestādes funkcijas pildīšanu un atbild par to, vada iestādes administratīvo darbu, nodrošinot tā nepārtrauktību, lietderību un tiesiskumu, tajā skaitā pārvalda iestādes finanšu, personāla un citus resursus, kā arī izveido iestādes IKS, uzrauga un uzlabo to;

- ir atbildīgi par budžeta līdzekḷu efektīvu un ekonomisku izlietošanu atbilstoši paredzētajiem mērḳiem.

Šì uzdevuma veikšanai informāciju var iegūt MK 08.05.2012. noteikumos Nr. 326 "Noteikumi par iekšējās kontroles sistēmu tiešajās valsts pārvaldes iestādēs", kas nosaka IKS darbïbas pamatprasības, kontroles vides izveidošanu, risku novērtēšanu u. c. Pašvaldību vadītāji gan norāda minēto MK noteikumu darbïbas jomas un uzskata, ka noteikumi neattiecas uz pašvaldībām, bet gan uz valsts tiešās pārvaldes institūcijām, tomēr likumā "Par budžetu un finanšu vadību" noteiktie pienākumi pašvaldību vadītājiem liek izveidot IKS.

LR VK Ministru kabinetam ir ieteikusi:

1) ierosināt grozijumus normatìvajos aktos, paredzot uz pašvaldībām un to iestādēm attiecināmas normatīvo aktu prasības par IKS izveidi; un

2) nodrošināt pašvaldības augstākā un vidējā līmeņa vadītāju apmācību iespējas par IKS izveidošanu, dokumentēšanu, kontroles pasākumu īstenošanu, informācijas un saziņas nodrošināšanu, IKS uzraudzību un uzlabošanu.

Ieteikumi sākotnēji tika sniegti FM, taču FM neatbalstija šo ieteikumu, skaidrojot, ka ieteikumu ieviešana ir citu ministriju/iestāžu kompetences jautājumi. Iepriekšminēto problēmu risinājums varētu būt IA funkcijas izveidošana un nostiprināšana pašvaldībās, kas ievērojami uzlabotu kontroles vidi un procedūras.

Autores secinājums - IA pašvaldībās ir nepieciešams, ko ir pierādījusi prakse. 2016. gadā 22 no 119 pašvaldībām ir ieviesušas IA struktūrvienību vai iekšêjā auditora štata vietu. Protams, IA pozitīvā ietekme ir atkarīga no iekšèjā auditora profesionalitātes, kas pašvaldībās pašlaik nav izmērāma, taču kā viens no galvenajiem IA kvalitātes rādītājiem būs sakārtota pašvaldību IKS.

Autores ekspertu aptaujas rezultāti parādīja, ka ekspertiem ir atšķirīgi viedokḷi par IA pamatprincipu ievērošanu. 
Autore uzskata, ka IA pamatprincipi, kas ir noteikti Standartos, Ētikas kodeksā un IA definīcijā, skaidri noteic, ka ir jānodrošina neatkarība, objektivitāte un efektivitāte neatkarīgi no iestādes, kurā iekšējais auditors pilda savus pienākumus, neatkarīgi no dažādām problēmsituācijām, kas var rasties darba gaitā.

Jaunas sistēmas IA ieviešana pašvaldībās prasīs noteiktus resursus darba vietas izveidei un darba samaksai, taču iekšêjās kontroles sistēmas tiks sakārtotas, izmantojot IA funkciju.

Pētijuma rezultātā autore izstrādājusi ieteikumu - FM, sadarbojoties ar VARAM, jāizstrādā vienota IA ieviešanas sistēma Latvijas Republikas pašvaldībās, normatīvajos aktos nosakot pamatprasības, kas nodrošinās vienotu pieeju audita sistēmas izveidei un isstenošanai, IA rezultātu vienotai apkopošanai, publicěšanai un sabiedrības informēšanai. Apkopojot iepriekšminēto, autore piedāvā priekšlikumu - likuma "Par pašvaldībām" 5. pantā iekḷaut normu šādā redakcijā: "Efektīvas un lietderīgas pašvaldību pārvaldes darbības nodrošināšanai pašvaldībās un to iestādēs tiek nodrošināta IA funkcija." Savukārt 5. panta ceturtā dą̧a jāpapildina ar FM pienākumu koordinēt IA darbību pašvaldībās.

Iekšèjā audita likuma 2. panta 6. punkts ir papildināms un izsakāms šādā redakcijā: "Iekšějais audits - iekšejjā auditora neatkarīga un objektīva darbība, kuras rezultātā tiek sniegts iekšèjās kontroles sistēmas darbības novērtējums, lai pilnveidotu iekšèjās kontroles sistēmas darbību ministrijā, iestādē un pašvaldībā."

Minētā likuma 3. panta pirmajā daḷā iekḷaujama norma, ka likums attiecas uz ministrijām, iestādēm un pašvaldībām, savukārt 2. punkta redakcija grozāma un izsakāma šādi: "Atvasinātās publiskās personās, izṇemot pašvaldības, iekšèjā audita sistēmu, iekšējā audita darba organizāciju un iekšèjā audita veikšanas kārtību nosaka tās lēmējinstitūcija."

Lai nodrošinātu IA funkcijas efektīvāku veikšanu, atvasinātas publiskas personas lēmējinstitūcija, ja nepieciešams, var slēgt sadarbības līgumu ar attiecīgās nozares ministriju par šis personas iekḷaušanu ministrijas IA sistēmā.

\section{Pašvaldību IA sistēmas izveidei autore piedāvā divas alternatīvas:}

1. alternatīva. IA struktūrvienība izveidojama lielās un ḷoti lielās pašvaldībās (iedzīvotāju skaits pārsniedz 20 000; atbilstoši MK 30.11.2010. noteikumu Nr. 1075 "Valsts un pašvaldību institūciju amatu katalogs"; sk. 5. pielikumu). IA tiek plānoti katru gadu, un iekšējie auditori katru gadu sagatavo ziņojumu atbildīgajai ministrijai (FM) par IA darbību pašvaldībā. Pārējās pašvaldībās jānodrošina IA veikšana 3-5 gados, atkarībā no prioritātes aptverot visas pašvaldības sistēmas. Darbu var organizēt, pieaicinot ārpakalpojuma speciālistus vai pien,emot darbā iekšējo auditoru uz noteiktu laiku. 
2. alternatīva. Pēc pašvaldību reformas, pie kuras izveides pašreiz strādā VARAM, lai vairotu teritoriju ekonomiskās attīstības potenciālu un pašvaldību sadarbību publisko pakalpojumu sniegšanā, par 29 apriņ̧̧̧u jeb pašvaldības sadarbības teritorijām ieviest IAS visos pašvaldību 29 sadarbības teritoriju jeb apriņķu centros. Divdesmit deviņas sadarbības teritorijas ir 21 regiionālās nozīmes attīstības centrs un deviņas republikas pilsētas (Jūrmala pie Rīgas). IA plānošana lielajās pašvaldībās būtu nepārtraukta, bet mazajās un vidēji lielajās pašvaldībās (līdz 20000 iedzīvotāji) - periodiska, kas praktiski îstenotos šādā veidā: lielajās pašvaldỉbās sistēmas tiek auditētas vismaz reizi 3-5 gados, atkarībā no prioritātes, savukārt mazajās - vispārējs IA, kas aptvertu visas pašvaldības sistēmas, tiktu veikts vismaz reizi piecos gados. Autore uzskata, ka abas izvirzìtās alternatīvas ir viena otru izslēdzošas.

Ir secināts, ka viena pakalpojuma sniegšanas izmaksas dažādās pašvaldībās būtiski atškiiras un, pašvaldībām sadarbojoties, iespējams tās samazināt. Tādējādi pašvaldības budžetā tiktu ietaupîti papildu resursi, ko varētu izmantot citu iedzìvotājiem nepieciešamu pakalpojumu kvalitatīvai sniegšanai. ${ }^{128}$

Autore uzskata, ka IAS būtu apriṇku centrā, un auditoru darbība tiktu nodrošināta visās pašvaldībās, kas ietilpst šajā teritorijā, piemēram, Rēzeknes apriṇ̂,ị ietilpst Rēzeknes pilsēta, Rēzeknes novads, Viḷānu novads vai Talsu apriņķī ir Talsu novads, Mērsraga novads, Rojas novads, Dundagas novads utt. Iekšējo auditoru pakalpojumu izmantošana iespējama šādi: tiek slēgti līgumi ar katru pašvaldỉbu atsevišķi vai arī viens līgums ar apriņķa vadību, ja tāda tiek izveidota pēc reformas īstenošanas.

2017. gada sākumā veiktās LR VK revīzijās par pašvaldību administratīvo resursu produktīvu un ekonomisku izlietojumu konstatētas vairākas neproduktīvas darbības - lieku dokumentu sagatavošana, drukāšana, pavairošana, aprite un uzglabāšana, nepilnvērtīga pašvaldību rīcībā esošo informācijas sistēmu izmantošana. Piemēram, LR VK revidenti aprēḳinājuši - kādā no novadiem veidojas vismaz četru grāmatvedības darbinieku slodžu rezerve un potenciālais ietaupijums gadā varētu būt vismaz 43000 EUR.

Autore uzskata, ka šādas minētās vai citas rezerves vietā pašvaldībā vai centralizēti sadarbības teritorijā ir iespēja nodarbināt iekšējos auditorus, kas varētu uzsākt un pakāpeniski sakārtot iekšējās kontroles procesus.

IA darba grupas veido vismaz no diviem auditoriem, viens auditors varētu būt tikai izṇēmuma gadījumos. Autore piekrīt $H$. Kagerman viedoklim, ka viens

\footnotetext{
${ }^{128}$ Klismeta G. Saruna ar VARAM ministru K. Gerhardu. Vai nu "A" vai "B". Logs, 2017, Nr. 1 (259). Pieejams: http://www.lps.lv/lv/zurnals-logs-infolapa/zurnals-logs/ [skatits 22.04.2017.]
} 
iekšējais auditors ir struktūrvienības vadītājs, kas ir atbildīgs kopumā par IA funkcijas nodrošināšanu - plānošanu, ziņošanu, bet otrs ir izpildītājs ${ }^{129}$.

Autore uzskata, ka IAS jābūt pakḷautai pašvaldības domei (sk. 3.5. attēlu), kas veicinātu standartu un labās prakses pieredzi, tādējādi nodrošinot IA neatkarību un log̣isku ziņošanu augstākajai vadỉbai 1. alternatīvas gadỉjumā. Pēc pašvaldību reformas, izpildoties 2. alternatīvas nosacỉjumiem, IAS būs pakḷauta sadarbības teritorijas vadíbai jeb apriņķa vadíbai.

Apkopojot iepriekš konstatēto, autore izstrādājusi priekšlikumu: IAS izveidei un darbïbas pamatprincipiem ir jābūt iekḷautiem likumos un MK noteikumos, turklāt ir jābūt skaidri noteiktai IA struktūrai, iekšējo auditoru ziņošanas kārtībai attiecībā uz vadību un audita komitejas funkcijām. Tāpat jānosaka tas, ka visu pašvaldību IA gada ziṇojums "Par IA rezultātiem Latvijas pašvaldībās kārtējā gadā” ir publiski pieejams.

\subsection{2. lespējamie iekšējā audita risinājumi pašvaldībās}

Pamatojoties uz teorētisko pētijumu un IAI praktiķu viedokḷiem, autore izveidojusi Latvijas pašvaldībām pielāgotu IA modeli (sk. 3.6. attēlu). Modelī tiek piedāvāts veidot Audita komiteju, kuras sastāvā jāietver atbildīgo un nozares ministriju (FM un VARAM) pārstāvji, IA un pašvaldību lietu profesionāḷi un eksperti. Augstākā vadība pašvaldībās ir dome un domes priekšsēdētājs kā vadītājs. Atbilstoši normatīvajiem aktiem ārējo auditu pašvaldībās veic gan LR VK, gan zvērināti revidenti. IA ir pakḷauts pašvaldības domei un audita komitejai, kas ir valsts līmeņa uzraugošã institūcija.

Triju aizsardzības līniju principu - iekšèjās kontroles un risku vadības modeli - ir mēginājušas piemērot un ieviest dažādas organizācijas pasaulē, pamatojoties gan uz regulatora prasībām (Basel II - finanšu institūcijām), gan citām, arī IAI, iniciatīvām. Modelis aptver visus organizācijas procesus un pats par sevi var nedarboties, ja organizācijā nebūs spēcìga risku kultūra, laba komunikācija un izpratne, kā arī spēcīga risku sapratne/apzināšanās. ${ }^{130}$

3.6. attēlā redzamās aizsardzības līnijas autore modelī iekḷauj nemainītas, kādas tās atspogulotas IAI izstrādātajā modelī: pirmā aizsardzības līnija ietvert atbildību par novērtēšanu, par risku mazināšanu, vienlaikus saglabājot efektīvu iekšējo kontroli; otrā aizsardzības līnija nodrošina efektīvu riska vadības procesu ar darbību pārvaldību; trešajā aizsardzības līnijā IA funkcija nodrošina iestādes vadību ar informāciju un vērtējumu, cik efektīvi iestāde pārvalda tās riskus.

\footnotetext{
${ }^{129}$ Kagerman H., Kinney W. et al. Internal Audit Hanbook. Germany, Springer, 2008, p. 608.

${ }^{130}$ Miķelsons S. Iekšējais audits kā uzṇemmuma treša aizsardzības liniija. Iekšějo auditoru institūts, 15.12.2011.
} 


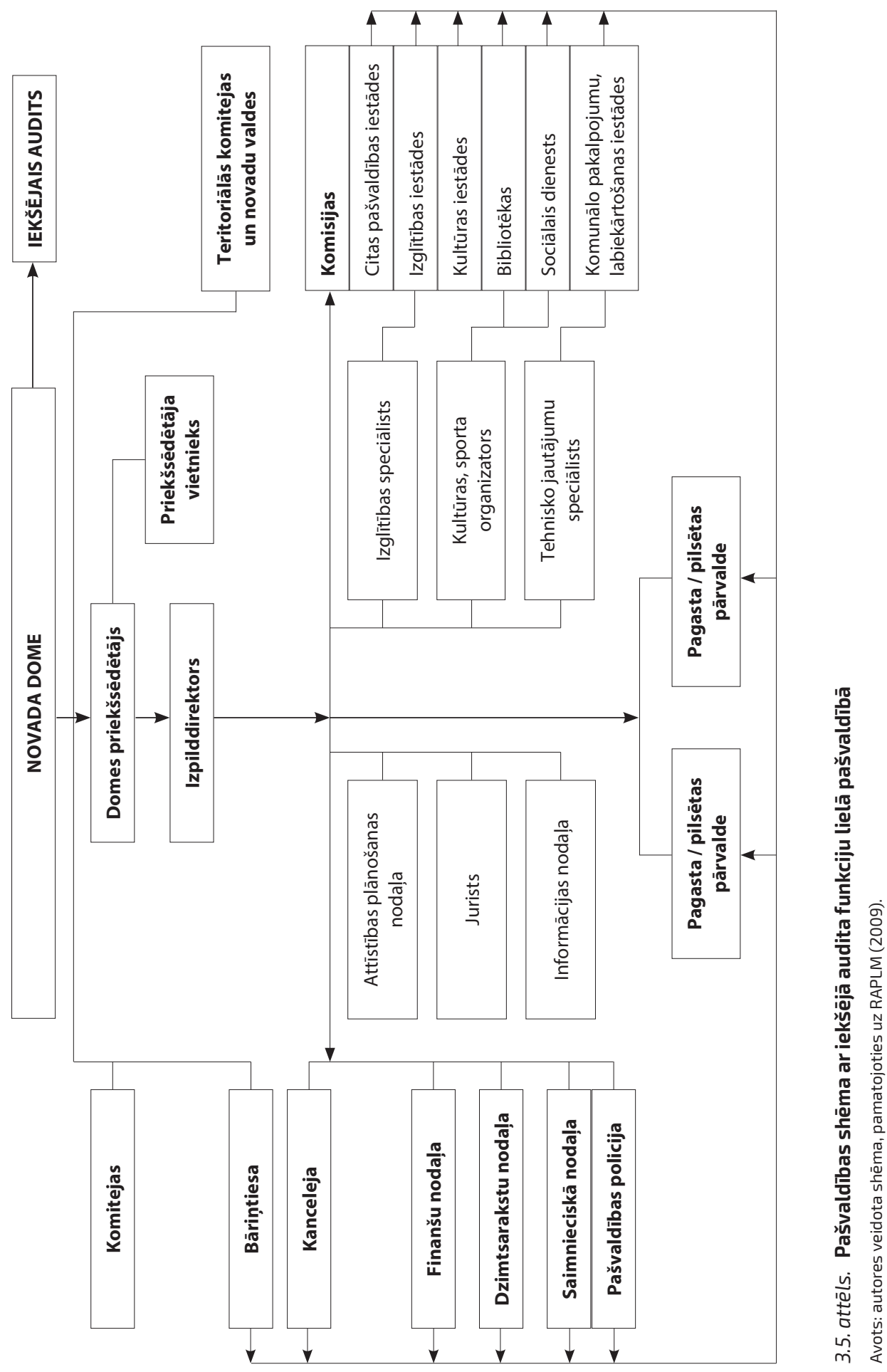




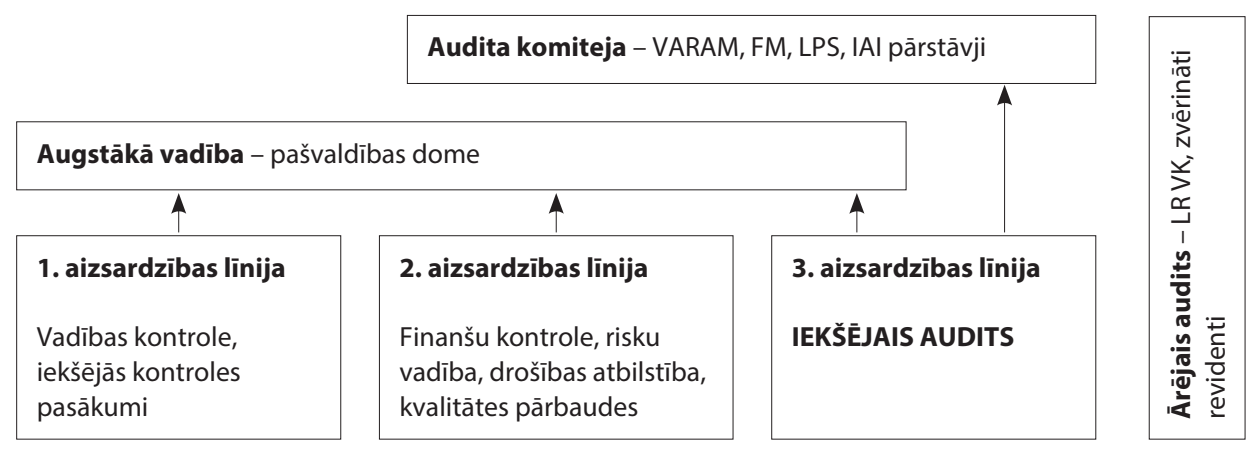

3.6. attēls. lespējamais IA un trīs līniju aizsardzības modelis Latvijas pašvaldībās Avots: autores veidots modelis, izmantojot ECIIA FERMA (2012).

Autore uzskata, ka normatīvajos aktos ietvertajam IA regulējumam jābūt elastīgam un pašvaldībām jālauj izvēlēties kādu no pasaulē un Latvijā pārbaudītām praktiskajām pieejām IA funkcijas īstenošanā. Lai nodrošinātu neatkarīgu un objektīvu IKS novērtēšanu, lai uzlabotu šìs sistēmas darbību pašvaldībās, autore piedāvā vairākas pētījuma gaitā radušās pieejas IA funkcijas ieviešanas risinājumiem:

1) valsts tiešās pārvaldes IA metodikas pārṇemšana, to pielāgojot pašvaldību vajadzībām;

2) IA kā ārpakalpojums;

3) risku vadǐšanas iespējas;

4) brieduma model̦a ieviešana;

5) kontroles pašnovērtējums.

Autore uzskata, ka jāizmanto vairākus gadu desmitus ilgā pasaules un nu jau arī Latvijas 17 gadu pieredze, kā Latvijas pašvaldību IA jāizmanto jau pārbaudìtas un praksē esošās vai kāda no jaunākajām pieejām IA jomā.

Tālāk sīkāk tiks analizēti visi pieci minētie IA funkcijas risinājumi.

1. Valsts tiešās pārvaldes IA metodikas pārṇemšana, pielāgojot pašvaldību vajadzībām. Pieredze, kas Latvijas valsts pārvaldē veidojusies 17 gadu laikā, ir vērā ņemama.

Izmantojot esošos IA regulējošos normatīos aktus, atbildīgā ministrija (FM) var izveidot IA rokasgrāmatu pašvaldībām, aizvietojot ar to VARAM mājaslapas sadạ̣ā Publikācijas un pētījumi > Metodiskie materiāli pašvaldībām izvietoto Latvijas Pašvaldību audita vienību rokasgrāmatu latviešu un anģ̣u valodā un iekḷaujot jaunizveidotajā rokasgrāmatā izmaiṇas, kas nepieciešamas saskaņā ar pašvaldības regulējumu. 
2. Iekšējais audits kā ārpakalpojums. Latvijā jau daudzus gadus pastāv ārpakalpojumi grāmatvedībā, lietvedībā, IT u. c. jomās. IA nodošana ārpakalpojumā gan nav guvusi pietiekami lielu popularitāti.

Standarti nosaka: IAS vadītājam ir jānodrošina, ka jebkurš audits tiek isstenots, nodrošinot auditoriem tā veikšanai nepieciešamās zināšanas, iemaņas un citu veidu kompetences. Šķiet, ka šāds savu zināšanu izvērtējums ir diezgan liels izaicinājums lielākajai dal̦ai iekšējo auditoru, jo pastāv diezgan daudz organizāciju, kurās ir tikai viens auditors, tomēr iekšējais audits tiek veikts bez jebkāda ārpakalpojuma sniedzēja piesaistes. Standarti ir obligāti, ja tie ir iekḷauti struktūrvienības nolikumā, kā arī individuāli IAI biedriem, tomēr pārliecību var sniegt tikai IAS novērtējums. ${ }^{131}$

No vienas puses, nepieciešamais prasmju kopums un zināšanas ir visai daudzpusīgas un sarežg̀itas, tāpēc tās reti ir apvienotas vienā atsevišķā personā vai nelielā organizācijas darbinieku pulciṇā. Tas varētu būt galvenais faktors, lai izvēlētos IA pakalpojumu. No otras puses, jānnem vērā šāda pakalpojuma augstās izmaksas, kas liek samazināt IA atvēlēto laiku. Turklāt pastāv risks, ka pakalpojumu sniedzošais auditors nepilnīgi pārzina organizācijas mērķus, kultūru vai biznesu. Tajā pašā laikā IA pakalpojuma formā vairāk fokusēsies uz izmaksām un efektivitāti, pakalpojuma nolīgšana varētu palielināt IA neatkarību un, visbeidzot, izmantojot pakalpojuma sniedzēju - profesionāli, IA prasīs mazāk vadības laika, turklāt pakalpojumus iespējams nolīgt uz noteiktu laiku ${ }^{132}$.

Speciālisti raksturo iespējamos trīs veidu ārpakalpojums: ierobežots ārpakalpojums, dalı̄ēs ārpakalpojums un pilnīgs ārpakalpojums.

Ierobežots ārpakalpojums - parasti šādā ārpakalpojumā tiek nodota ierobežota IA funkcija, piemēram, iekšējo procedūru izstrāde, dažu speciālistu piesaiste konkrētos auditos, tomēr IAS un audita projektus pārrauga struktūrvienības vadītājs. Ieguvumi - uzlabota IA pakalpojumu kvalitāte, kas tiek iegūta, nodrošinot resursu piesaisti tikai jomās, kurās trūkst kompetences vai nepietiek laika resursu to veikt ar iekšējiem resursiem. IA programmas iegādājas no ārpakalpojumu sniedzēja, auditu veicot ar iekšèjiem resursiem un tādējādi nodrošinot kvalitatīvu risku izvērtējumu, kas jau daļeji samazina risku, ka audits nespēs atklāt būtiskākos IKS trūkumus, ja tādi pastāvētu.

Daḷējs ārpakalpojums - tajā iekšējais resurss ir IAS vadītājs, kas izmanto ārpakalpojuma sniedzēja piedāvāto audita darba grupu. IAS atbildība ir IA

\footnotetext{
${ }^{131}$ Grūba I. (2010) Nodošana ārpakalpojumā - plusi un mīnusi. Saldo. Dienas Bizness, Nr. 6, 18. lpp. ${ }^{132}$ Movsisjana A. (2006) Iekšějā audita nenovērtētāā loma: no diagnozes līdz prognozei. Bilance, Nr. 3, 30.-31. lpp.
} 
projektu pārraudzība, komunikācija ar vadỉbu un audita komiteju (ja tāda pastāv) par secinājumiem. Ieguvumi - tiek nodrošināta skaidra vadības atbildība par IA secinājumiem, tiek nodrošināti piemērotākie cilvēkresursi, ātrāk tiek izmantota jaunākā IA metodika, pastāv niecīga iespēja pakḷauties auditējamo spiedienam saistībā ar IA secinājumiem.

Pilns ārpakalpojums - ārpakalpojumā tiek nodota visa IA funkcija, tiek norīkota atbildīgā persona par komunikācijas nodrošināšanu, vadība apstiprina IA plānu un periodiski saņem informāciju par IA projektos atklāto. Šajā modelī IA tiek nodrošināta maksimāla neatkarība un viedokḷu objektivitāte, kā arì tas prasa mazāk vadības uzmanības ${ }^{133}$.

Autore uzskata, ka visi trīs ārpakalpojumu veidi ir izmantojami pašvaldībās, jo situācijas var būt dažādas, it īpaši sākotnējā posmā. Pilnīgs ārpakalpojums, iespējams, būs dārgāks, bet līguma slēgšana, skaidri definējot uzdevumus, ir vienkāršāka salīdzinājumā ar ierobežotu vai daḷēju ārpakalpojumu, kur darbs komandā varētu radīt papildu škēesšlıs savlaicīgam un kvalitatīvam IA rezultātam.

3. Risku vadīšanas iespējas pašvaldībās. Tā, pēc autores domām, ir viena no galvenajām un svarīgākajām IA ieviešanas pieejām.

Savlaicīga, profesionāla un precīza risku analīze ir viens no veiksmīgas uzņēmējdarbības priekšnoteikumiem. Atbilstoši ekonomikas teorijai jebkurš uzņēmums ir pakḷauts dabas riskam, politiskajam riskam, tirgus riskam, finansiālajam riskam, ražošanas riskam un cilvēciskā faktora riskam. ${ }^{134}$

Riska vadība ir kḷuvusi par neatņemamu vadītāju ikdienas darba sastāvdaļu, un termins "risks" tiek lietots biežāk un biežāk, lai ikdienas profesionālajā darbībā aizvien gudrāk un efektīvāk novērstu jebkādus šḳērṣ̌lus ceḷā uz izvirzìtajiem mērksiem. IAI sadarbībā ar FM 2011. gada nogalē izstrādāja kopīgu projektu valsts pārvaldes iestāžu darbībā pastāvošo risku apzināšanai. Projekta rezultātā tapa kopīgs valsts pārvaldes iestāžu ikdienas darbu tādu ietekmējošo risku saraksts, kuri analīzes nolūkos tika grupēti četrās riska jomās un 19 riska kategorijās ${ }^{135}$.

\footnotetext{
${ }^{133}$ Grūba I. (2010) Nodošana ārpakalpojumā - plusi un mīnusi. Saldo. Dienas Bizness, Nr. 6, 18.-19. lpp.

${ }^{134}$ Liepiṇa I. (2009) Uzṇēmuma risku atklāšana un novērtēšana ar pašu spēkiem. Bilance, Nr. 18 (22), 28.-31. lpp.

${ }^{135}$ Sīle L. (2012) IAI un FM īstenotais kopprojekts "Risku modelis valsts pārvaldei". IAI Vēstnesis, Nr. 4, 7. lpp.
} 


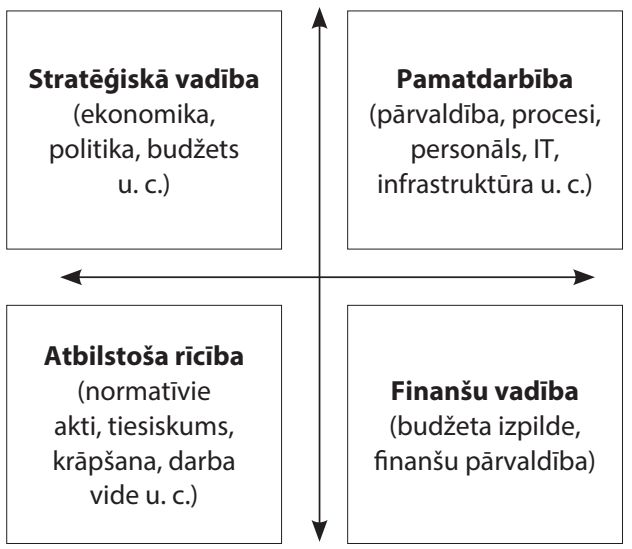

\section{7. attēls. Risku grupēšana pēc riska jomas un riska kategorijas}

Avots: autores veidots, pamatojoties uz Sïle (2012) 7. lpp.

Autore uzskata, ka minētais risku saraksts (sk. 3.7. attēlu) izmantojams pašvaldībās, jo ḷauj norādītās jomas un kategorijas papildināt pēc nepieciešamības. Šādu risku sarakstu iespējams iekḷaut pašvaldību IA regulējošos normatīvajos aktos.

Iekšèjiem auditoriem un riska vadības speciālistiem ir dažas kopīgas zināšanas, prasmes un vērtības. Piemēram, abu tipu speciālistiem ir izpratne par uzṇēmumu pārvaldības prasībām, projektu vadības, analìtiskās un organizatoriskās prasmes, tādas vērtības kā lìdzsvarota riska apziṇa, nevis maksimāla riska uzņemšanās vai nepiel̦aušanas taktika. Taču pēc būtības riska vadības speciālisti strādā tikai organizācijas vadības labā un to pienākumos nav neatkarīgas, objektīvas pārliecības sniegšana audita komitejai. Iekšējiem auditoriem, kas plāno uzṇemties plašākus riska vadības pienākumus, nevajadzētu nenovērtēt riska vadības speciālistu zināšanas jomās, kuras ir ārpus lielākās iekšējo auditoru daḷas kompetences (piemēram, riska pārnešanas, riska kvantitatīvās analīzes un modelěšanas metodes). Iekšêjiem auditoriem, kuriem nepiemīt atbilstoša līmeņa prasmes vai nav zināšanu minētajos jautājumos, nevajadzētu uzņemties ar tiem saistītus darba uzdevumus. Vēl jo vairāk tad, ja nav iespējams nodrošināt attiecīgās prasmes un zināšanas ne IA struktūrvienībā, ne iegūt tās no citām pusēm, IA vadītājam vajadzētu atteikties arī no konsultāciju sniegšanas minētajos jautājumos. ${ }^{136}$

\footnotetext{
${ }^{136}$ IAI oficiālā nostāja par iekšējā audita lomu kompleksajā uzṇēmuma riska vadībā. Pieejams: http:// www.iai.lv/files/Biedriem/standarti/2010/ippf_pp_role_of_ia_in_erm_lv_01.09.2010.pdf [skatits 23.08.2012.]
} 
Autore ierosina izmantot valsts tiešãs pārvaldes MK 09.07.2013. noteikumos Nr. 385 "IA veikšanas un novērtēšanas kārtība" ietvertos riska faktorus. Lai noteiktu IA vidē iekḷauto sistēmu prioritāti, IAS valsts tiešās pārvaldes iestādēs izvērtē astoņus faktorus, bet pašvaldībās autore ierosina risku noteikšanas vērtējamo faktoru sarakstā papildus iekḷaut faktoru "iedzīvotāju skaita izmaiṇas pašvaldībā".

Pašvaldību risku noteikšanas vērtējamie faktori būtu šādi:

1) iesaistìto resursu apjoms;

2) problēmas, par kurām ziņots iepriekšējos iekšējos auditos vai citos iekšējos informācijas avotos un ārējos auditos;

3) sistēmas nozīme pašvaldības mērķu sasniegšanā;

4) izmaiņas;

5) korupcijas (krāpšanas) iespēja;

6) nepieciešamā darbinieku kompetence;

7) pašvaldības reputācijas pasliktināšanās;

8) sistēmas sarežg̀itīiba;

9) iedzìvotāju skaita izmaiņas pašvaldībās.

Pēc tam kad riski ir identificēti, iekšējais auditors var aizpildìt risku vērtēšanas tabulu (sk. 3.1. tabulu).

Autore piedāvā izmantot risku noteikšanas faktoru vērtēšanu, veicot secīgas darbības: norādìt auditējamo objektu (projekts, sistēma); izvēlēties risku noteikšanas faktorus, noteikt faktora nozīmību procentos (visi faktori kopā veido 100\%); noteikt faktoru novērtēšanas skalu (skaitlisks novērtējums no viens līdz pieci vai aprakstošs - zems, vidējs, augsts); aprēķināt datus; novērtēt auditējamās sistēmas un aprēķināt galīgo rezultātu; noteikt audita prioritātes, pamatojoties uz iegūtajiem risku vērtēšanas rezultātiem.

Novērtējot savas pašvaldības auditējamās struktūrvienības riskus, autore iesaka pašvaldību iekšèjiem auditoriem vai iekšèjās kontroles speciālistiem darbā izmantot pašvaldības risku noteikšanas faktoru vērtēšanu atbilstoši 3.1. tabulas piemēram, mainot un papildinot faktorus pēc nepieciešamības un sadalot svara procentus starp izvēlētajiem faktoriem tā, lai kopsummā veidotos 100\%.

Riska pakāpes novērtējumu (RPN) iekšèjais auditors veic, pamatojoties uz savu pieredzi, kompetenci un zināšanām skalā no viens līdz pieci, savukārt svērtais riska pakāpes novērtējums (SRPN) jāaprēkinina pēc formulas, kurā riska pakāpes novērtējums (RPN) tiek reizināts ar konkrētā faktora svara \%, iegūstot koeficientu.

Autores veidotajā nosacītajā piemērā 3.1. tabulā ir iekḷauti tikai četri faktori no piedāvātajiem devininiem faktoriem, ko iekšējais auditors izvēlas, kad izvērtē katras konkrētās pašvaldības situāciju un auditējamās prioritātes, pamatojoties 
3.1. tabula. Piemērs pašvaldības risku noteikšanas faktoru vērtēšanai

\begin{tabular}{|c|c|c|c|c|c|c|c|c|c|}
\hline \multirow{3}{*}{ 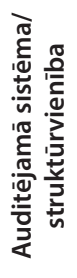 } & \multicolumn{2}{|c|}{$\begin{array}{c}\text { 1. faktors - } \\
\text { iesaistīto resursu } \\
\text { apjoms }\end{array}$} & \multicolumn{2}{|c|}{$\begin{array}{l}\text { 2. faktors - } \\
\text { problēmas, par } \\
\text { kurām zin̨ots } \\
\text { iepriekšejos } \\
\text { auditos }\end{array}$} & \multicolumn{2}{|c|}{$\begin{array}{c}\text { 3. faktors - } \\
\text { sistēmas nozīme } \\
\text { pašvaldības mērḳu } \\
\text { sasniegšanai }\end{array}$} & \multicolumn{2}{|c|}{$\begin{array}{c}\text { 4. faktors - } \\
\text { korupcijas } \\
\text { (krāpšanas) iespēja }\end{array}$} & 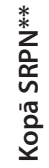 \\
\hline & \multicolumn{2}{|c|}{ Svars $40 \%$} & \multicolumn{2}{|c|}{ Svars $10 \%$} & \multicolumn{2}{|c|}{ Svars $20 \%$} & \multicolumn{2}{|c|}{ Svars 30\% } & \\
\hline & $\mathrm{RPN}^{*}$ & SRPN** & $\mathrm{RPN}^{*}$ & SRPN** & $\mathrm{RPN}^{*}$ & SRPN ${ }^{* *}$ & RPN* & SRPN** & \\
\hline A & 5 & 2 & 1 & 0,1 & 4 & 0,8 & 5 & 1,5 & 4,4 \\
\hline B & 2 & 0,8 & 2 & 0,2 & 4 & 0,8 & 5 & 1,5 & 3,3 \\
\hline C & 3 & 1,2 & 3 & 0,3 & 3 & 0,6 & 2 & 0,6 & 2,7 \\
\hline
\end{tabular}

$\mathrm{RPN}^{*}$ - riska pakāpes novērtējums skalā 1-5, kur 5 - visaugstākais risks. SRPN ** - svērtais riska pakāpes novērtējums, ko aprēkinina no RPN* faktora svara procentos.

Avots: autores veidota tabula, pamatojoties uz Finanšu ministrija, PricewaterhouseCoopers (2006).

uz intervijām ar vadību un darbiniekiem un ņemot vērā iepriekšējos iekšêjos auditos atklātās nepilnības, kā arī iekšèjā auditora personīgo pieredzi un zināšanas. Piemērā ir iekḷautas trīs dažādas struktūrvienības (A, B un C), kurām nosacīti novērtēti risku noteikšanas faktori.

4. Brieduma modeḷu izvēle - rīks pārliecības gūšanai un konsultāciju pakalpojums. J. Rose uzskata, ka brieduma modeḷi nosaka sistemātiskus novērtēšanas principus procesa pašreizējā stāvokḷa aprakstī̌sanai. Turpmāk procesa brieduma stāvokli iespējams salīdzināt ar rezultātiem, ko sagaida vadība, vai izmantot citu līdzīgu procesu brieduma stāvokḷa mērījumu veikšanai. Modelis l̦auj gūt ieskatu saistībā ar uzlabojumu alternatīvām, kuras vairo iespēju, ka laika gaitā procesa mērḳi tiks sasniegti. Brieduma modelis apraksta tās procesa sastāvdaļas, kuras, kā tiek uzskatīts, sekmē labākus iznākumus un rezultātus. ${ }^{137}$ 3.8. attēlā autore ir parādījusi brieduma izveides trīs soḷus un piecus papildsoḷus.

1. solī (sk. 3.8. attēlu) auditoram jāapsver, ko vadība vēlas novērtēt, vai modelis tiks piemērots dažādos vadības procesos vispārējai pārvaldībai, kontrolei vai organizēšanai, kāds ir IA uzdevums, kā audits var definēt procesu rezultātu, rādìtājus vai kvalitatīvu apgalvojumu ${ }^{138}$.

\footnotetext{
${ }^{137}$ Rose J. (2013) Brieduma modeḷu izvēle, izmantošana un izveide: Rīks izmantošanai pārliecības gūšanas, konsultāciju pakalpojumos. (IAI tulkojums)

${ }^{138}$ Turpat.
} 


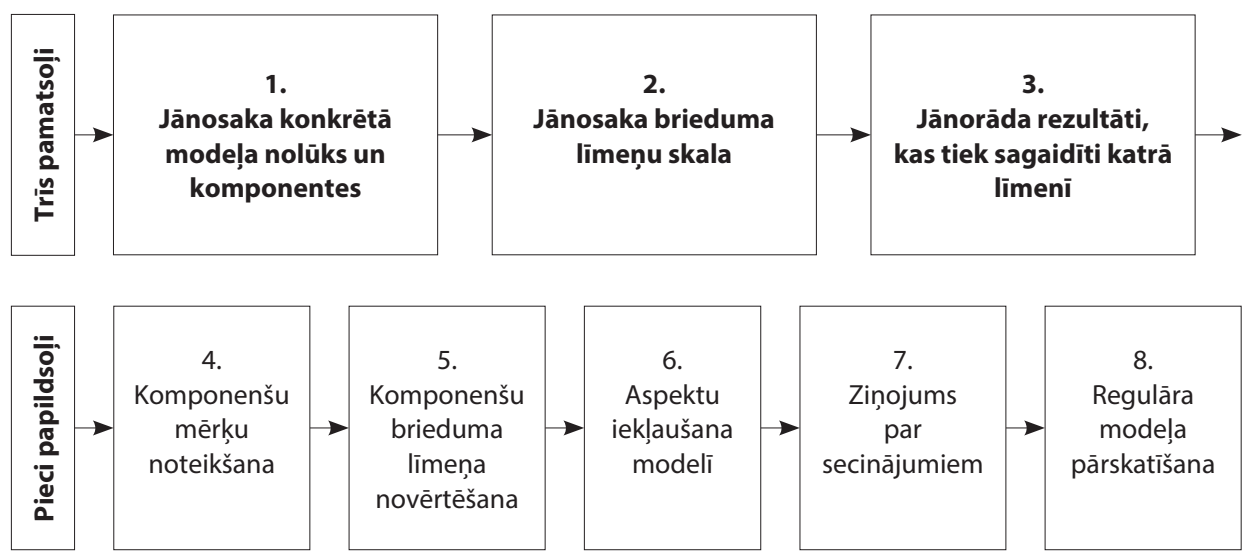

3.8. attēls. Brieduma modeḷa izveides un izmantošanas soḷi

Avots: autores veidota shēma, pamatojoties uz Rose (2013).

Valsts sektora IA spēju kontroles jeb brieduma modelis (sk. 3.2. tabulu), kas izveidots, pamatojoties uz IAIPF pieeju, lai novērtētu, kā valsts sektora IAS ietver IA spēju kontroli piecos dažādos līmen,os, attēlojot to, kā IAS var attīstīties un pilnveidoties.

Modeḷa 2. solī līmeņu skala jānosaka piecos līmeņos, kā attīstīties IA: 1. - sākotnējais jeb bāzes, 2. - infrastruktūras, 3. - integrētais, 4. - pārvaldītais un 5. - optimālais lìmenis.

3. solis definē sagaidāmos rezultātus, aplūkojot katram līmenim noteiktos mērḳus. To piemērojot, īpaši rūpīgi jāapsver vairāki jautājumi: cik veiksmīgi izdodas veidot katru līmeni, pamatojoties uz iepriekšèjo līmeni, vai visām komponentēm ir noteikti vienādi sagaidāmie rezultāti u. c.

4. solis - ne visām komponentēm būtu jāfunkcionē augstākajā brieduma pakāpē, turklāt organizācija var nevēlēties tērēt resursus. IA jāṇem vērā standartu prasības, kas attiecas uz risku un komunikāciju par riska uzņemšanos.

5. solis - auditori novērtē pašu procesu, veicot novērošanu, aptaujas, atkārtojot pārbaudes, procesa pašnovērtējumu.

6. solis - nevienā modelī nav iespējams iekḷaut visus faktorus, kuri var mazināt risku, ka netiks sasniegts kāds rezultāts. Modelis nav vienkāršs jautājumu saraksts.

7. solis - ziņojumā jāiekḷauj modeḷa izvēles pamatojums, sīkāka informācija par modeḷa uzbūvi. Auditoriem "jādomā ārpus modeḷa”, jāapsver, vai pārbaudāmie apstākḷi var radīt citas neatbilstības pārvaldībā, riskos un kontroles procesu ieviešanā. 


\section{2. tabula. lekšējā audita spēju kontroles matrica}

\begin{tabular}{|c|c|c|c|c|c|}
\hline 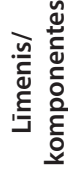 & $\begin{array}{c}\text { IA pakalpojumi / } \\
\text { loma }\end{array}$ & $\begin{array}{c}\text { Personāla } \\
\text { vadīšana }\end{array}$ & $\begin{array}{l}\text { Profesionālie } \\
\text { standarti }\end{array}$ & $\begin{array}{l}\text { Veiktspējas } \\
\text { pārvaldība un } \\
\text { atbildība }\end{array}$ & $\begin{array}{c}\text { Attiecības un kultūra } \\
\text { organizācijā } \\
\text { Pārvaldības } \\
\text { struktūra }\end{array}$ \\
\hline 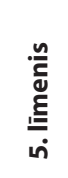 & $\begin{array}{l}\text { Galvenais izmainu } \\
\text { veikšanas faktors }\end{array}$ & $\begin{array}{l}\text { Augstākā līmeṇa } \\
\text { vadības iesaistī- } \\
\text { šana, darbaspēka } \\
\text { resursu plānošana }\end{array}$ & $\begin{array}{l}\text { Nepārtraukti } \\
\text { uzlabojumi, } \\
\text { stratēǵiska IA } \\
\text { resursu plāno- } \\
\text { šana }\end{array}$ & $\begin{array}{l}\text { Sabiedrības } \\
\text { informēšana } \\
\text { par IA darbī- } \\
\text { bas lietderī- } \\
\text { gumu }\end{array}$ & $\begin{array}{l}\text { Efektīvas un pastāvī- } \\
\text { gas attiecības } \\
\text { IAS neatkarība, piln- } \\
\text { varas, tiesības }\end{array}$ \\
\hline 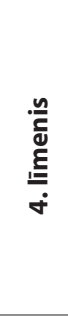 & $\begin{array}{l}\text { Pārliecība par } \\
\text { risku pārvaldību un } \\
\text { kontroli }\end{array}$ & $\begin{array}{l}\text { IA veicina pārval- } \\
\text { dības attīstību, } \\
\text { atbalsta profesio- } \\
\text { nālās organizāci- } \\
\text { jas, darbaspēka } \\
\text { resursu plānošanu }\end{array}$ & $\begin{array}{l}\text { Audita stratēǵi- } \\
\text { jā tiek izmanto- } \\
\text { ta organizācijas } \\
\text { risku pārvaldība }\end{array}$ & $\begin{array}{l}\text { Kvalitatīvo } \\
\text { un kvantita- } \\
\text { tīvo darbības } \\
\text { rezultātu } \\
\text { mērītāju } \\
\text { integrācija }\end{array}$ & $\begin{array}{l}\text { IAS konsultē aug- } \\
\text { stākā līmeña vadību } \\
\text { un ietekmē tās } \\
\text { lēmumus. } \\
\text { Neatkarīga IA darbī- } \\
\text { bas pārraudzība, IAS } \\
\text { sagatavo atskaites } \\
\text { augstākā līmeṇa } \\
\text { vadībai }\end{array}$ \\
\hline $\begin{array}{l}\stackrel{n}{E} \\
\stackrel{\underline{E}}{\underline{E}} \\
\dot{m}\end{array}$ & $\begin{array}{l}\text { Konsultācijas, } \\
\text { darbības rezultātu } \\
\text { un naudas līdzekl̦u } \\
\text { izlietojuma efektivi- } \\
\text { tātes auditi }\end{array}$ & $\begin{array}{l}\text { Komandu veidoša- } \\
\text { na, kompetenču } \\
\text { attīstīšana, kvali- } \\
\text { ficēts personāls, } \\
\text { darbaspēka resur- } \\
\text { su koordinēšana }\end{array}$ & $\begin{array}{l}\text { Kvalitātes } \\
\text { pārvaldības sis- } \\
\text { tēma (ietvars). } \\
\text { Uz risku balstīti } \\
\text { audita plāni }\end{array}$ & $\begin{array}{l}\text { Darbības } \\
\text { rezultātu } \\
\text { mērītāji, in- } \\
\text { formācija par } \\
\text { izmaksām, } \\
\text { IA vadības } \\
\text { ziṇojumi }\end{array}$ & $\begin{array}{l}\text { Koordinācija ar citām } \\
\text { pārbaudes grupām. } \\
\text { Vadības komandas } \\
\text { neatṇemama sastāv- } \\
\text { daḷa. } \\
\text { Vadības uzraudzība } \\
\text { par IAS darbību, } \\
\text { finansēšanas mehā- } \\
\text { nismi }\end{array}$ \\
\hline 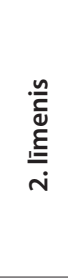 & Atbilstības auditi & $\begin{array}{l}\text { Individuāla profe- } \\
\text { sionālā attīstība, } \\
\text { darbā pieñemti } \\
\text { kvalificēti darbi- } \\
\text { nieki }\end{array}$ & $\begin{array}{l}\text { Profesionālo } \\
\text { standartu un } \\
\text { procesu ietvars. } \\
\text { Audita plāns ir } \\
\text { balstīts uz vadī- } \\
\text { bas ieinteresēto } \\
\text { pušu prioritā- } \\
\text { tēm }\end{array}$ & $\begin{array}{l}\text { IA operatīvais } \\
\text { budžets, } \\
\text { IA biznesa } \\
\text { plāns }\end{array}$ & $\begin{array}{l}\text { Pārvaldība IA struk- } \\
\text { tūrvienībā. } \\
\text { Pilnīga pieeja organi- } \\
\text { zācijas informācijai, } \\
\text { aktīviem un cilvēk- } \\
\text { resursiem, atskaites } \\
\text { par nodibinātām } \\
\text { attiecībām }\end{array}$ \\
\hline 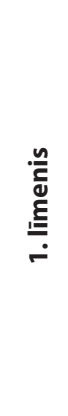 & $\begin{array}{l}\text { Situatīvas, nestruk- } \\
\text { turētas darbības, } \\
\text { daži vienreizēji audi- } \\
\text { ti, dokumentu un } \\
\text { darījumu pārbaude, } \\
\text { atbilstības novērtē- } \\
\text { šana, finansējums } \\
\text { pēc nepiecieša- } \\
\text { mības, rezultāts } \\
\text { atkarīgs no amata } \\
\text { prasmēm, nav infra- } \\
\text { struktūras }\end{array}$ & & & & \\
\hline
\end{tabular}

Avots: autores veidota tabula, pamatojoties uz Rey (2009) un Rose (2013). 
8. solis - pēc model̦a pielietošanas IA vajadzēs atkārtoti pārbaudìt, kāds ir katra ieviestā modeḷa elementa (lïmeņi, komponentes, mērķi) progress, virzoties uz vēlamajiem procesa rezultātiem (adaptēts pēc ${ }^{139}$ ).

Šo modeli autore pašvaldībām piedāvā kā vienu no iespējamām IA pieejām. Modeḷa ieviešana pašvaldībās prasītu ilgāku laiku, taču, novērtējot pašvaldību IAS pēc šīs vienotās sistēmas, būtu iespēja veikt Latvijas pašvaldību IAS novērtējumu un salīdzinājumu ilgtermin̄ā.

No IAIPF zinātnieku pētījuma rezultātiem (sk. 3.2. tabulu) autore secina, ka Latvijas pašvaldību IA spējas novērtējamas kopumā 1. līmenī, bet, iespējams, dažos gadījumos varbūt arī 2. vai 3. līmenī tajās pašvaldībās, kurās ir izveidota IAS, nevis ir tikai viens auditors.

5. Kontroles pašnovērtējums jeb kontroles sistēmas un risku pašnovērtējums ir nākamā iespēja Latvijas pašvaldībām - lietojot šo pieeju, iespējams radìt apstākḷus, kuros pašvaldības vadība un darbinieki spētu kritiski novērtēt savu IKS attiecībā pret pašvaldības funkciju mērķiem, riskiem un apstākḷiem.

Atbilstoši MK 09.07.2013. noteikumiem Nr. 385 "IA veikšanas un novērtēšanas kārtība” un FM publikācijām pašnovērtējuma procesā IAS pati novērtē savu darbu - audita efektivitāti, novirzes, cēloṇus un pilnveidojumus. Tā pašvaldību darbinieki aizpilda apmierinātības anketas, novērtējot savas zināšanas un prasmes vai izpratni par konkrētām jomām, kas ir svarīgas darbā, piemēram, struktūrvienības mērḳi, standarti, novērtējot to, vai pašvaldība vai struktūrvienība ir sniegusi iespējas pilnveidot zināšanas noteiktās jomās. Jebkura struktūrvienība, piemēram, Grāmatvedības nodal̦a vai Administratīvais departaments, var veikt pašnovērtējumu, atbildot uz jautājumu, vai struktūrvienība pašvaldībā ir stratēgiski izvietota tā, lai sekmētu organizācijas mērķu sasniegšanu un darba izpildi? Pašnovērtējuma mērķis - iegūt apliecinājumu, vai struktūrvienība darbojas atbilstoši normatīvajiem aktiem un labas prakses principiem, kā arī iegūt informāciju struktūrvienības novērtēšanai.

Kontroles pašnovērtējums pilnībā neaizstāj IAS funkcijas un darbību, tās mērķis ir papildināt audita funkciju, identificējot un samazinot riskus, koordinējot IK procedūras. Pašvaldību funkcijas ir reglamentētas ar dažādiem saistošiem dokumentiem - tām politikām, procedūrām, noteikumiem organizācijas iekšienē, kas ir pamatotas uz ārējiem likumiem, noteikumiem un prasībām. Saistošie dokumenti ir veidoti tā, lai finanšu, darbības un vadības informācija būtu

\footnotetext{
${ }^{139}$ Rose J. (2013) Brieduma modeḷu izvēle, izmantošana un izveide: Rīks izmantošanai pārliecības gūšanas, konsultāciju pakalpojumos. (IAI tulkojums)
} 
uzticama, skaidra, pilnīga, savlaicīga un lietojama. Vadībai jāievēro darījumu un darbības regularitāte, ekonomija, iegādājoties un izmantojot resursus, aktīvu saglabāšana, nodrošinoties pret zaudējumiem un bojājumiem. ${ }^{140}$

Lai varētu efektīvi novērtēt iespējamos riskus, jebkuru funkciju (darījumu) katra struktūrvienība pati analizē no sākuma līdz brīdim, kad to var uzskatīt par pabeigtu, uzdodot šādus jautājumus: kādas ir iespējamās kḷūdas, kas var atgadīties, kādas nepilnības iespējamas? Šādā izvērtēšanā vērtīgs atbalsts ir darbinieki, kuri ikdienā veic šos uzdevumus. Viņi nosaka riskus un veic riska līmen̦a novērtējumu - augsts, vidējs vai zems. Struktūrvienību darbinieki veic nepieciešamos pasākumus (izmaina procedūras, noteikumus utt.), lai nodrošinātos pret riskiem, kas traucē sasniegt noteiktos mērķus. Katra struktūrvienība ir pilnībā atbildīga par to risku pārvaldīšanu, kas ir saistīta ar tās aktivitātēm. Struktūrvienības vadītājs un darbinieki diskusijā vispirms apspriež visus nodal̦as mērķus, pēc tam soli pa solim iziet visas darbïbas, izvērtējot iespējas kḷūīities, t. i., identificē riskus, tālāk pašsaprotami seko risku un jomu novērtēšana, tiek noteikti kontroles elementi un pārskatīta pienākumu sadale un atbildība procedūrās, nodalot pienākumus un nosakot pilnvaras. Secīgi pašnovērtējuma procesā jāpārskata amatu apraksti un pastāvošās procedūras, jāveic labojumi pastāvošajās procedūrās, jāaizpilda risku kopsavilkumu tabula (sk. 3.3. tabulu) un noslēgumā gan šì tabula, gan pārējie secinājumi jāiesniedz audita komitejai vai vadỉbai.

\section{3. tabula. Paraugs "Risku novērtēšana pašvaldībā"}

\begin{tabular}{|c|c|c|c|c|c|c|c|}
\hline \multirow[b]{2}{*}{$\frac{\tilde{n}}{\frac{\tilde{n}}{x}}$} & \multicolumn{3}{|c|}{ Riska lïmenis } & \multirow[b]{2}{*}{$\begin{array}{c}\text { Kontroles } \\
\text { instrumenti, lai } \\
\text { šo risku novērstu }\end{array}$} & \multirow[b]{2}{*}{ Procedūra } & \multirow[b]{2}{*}{$\begin{array}{c}\text { Atbildīgā } \\
\text { persona }\end{array}$} & \multirow[b]{2}{*}{$\begin{array}{c}\text { Nepieciešamās } \\
\text { aktivitātes }\end{array}$} \\
\hline & 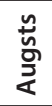 & $\frac{n}{i \frac{0}{0}}$ & $\stackrel{n}{\tilde{N}}$ & & & & \\
\hline 1. & $X$ & & & $\begin{array}{l}\text { Procedūras, } \\
\text { darbinieku } \\
\text { instruktāžas }\end{array}$ & Nr. 5 & K. K. & $\begin{array}{l}\text { Procedūru pārskatīšana, } \\
\text { darbinieku kontrole }\end{array}$ \\
\hline 2 & & $x$ & & $\begin{array}{l}\text { Darbinieku } \\
\text { regulārs } \\
\text { novērtējums }\end{array}$ & Nr. 3 & A. B. & $\begin{array}{l}\text { Darbu izpildes izlases } \\
\text { kontrole }\end{array}$ \\
\hline \multicolumn{8}{|c|}{ u. c. } \\
\hline \multicolumn{5}{|c|}{$\begin{array}{l}\text { Atbildīgā struktūrvienība. Darbinieks. } \\
\text { Amats }\end{array}$} & \multicolumn{2}{|l|}{$\begin{array}{l}\text { Datums } \\
+.20\end{array}$} & Paraksts \\
\hline
\end{tabular}

Avots: autores veidota tabula, pamatojoties uz Blažēviča (2000).

\footnotetext{
${ }^{140}$ Blažěviča I. (2000, febr.) Iekšējais audits. Grāmatvedība un revizija, LRZA, 32.-35. lpp.
} 
Kontroles pašnovērtējuma priekšrocības vadībai ir informācijas sniegšana par kontroles sistēmas stāvokli; iespēju piedāvāšana nodrošināties pret pastāvošajiem riskiem; nepieciešamās dokumentācijas un darbības plāna līmeṇa nodrošināšana, lai novērstu trūkumus. Tāpat pašnovērtējums ievieš skaidrību par atbildības līmeni un pievērš vadības uzmanību tādiem jautājumiem kā krāpšana, normatīvo aktu prasības, izmaksu samazināšana, ienesīgums un palīdzība vadībai veikt savus pienākumus attiecībā uz kontroles vadības jautājumiem, kā arī iespējamo komunikācijas iespēju piedāvāšana.

Apkopojot iepriekš nodaḷā piedāvāto, autore izveidojusi tiešu pašvaldību IA funkcijas pielietošanas un alternatīvo pieeju modeli (sk. 3.9. attēlu). Lai raksturotu katras vienības galvenos uzdevumus, autore izmantojusi Latvijas Republikas normatīvos aktus, kas attiecas uz valsts tiešās pārvaldes IA sistēmu, IAI piedāvāto modeli IAS un Standartus. Modelī tiek pieņemts, ka IA ir ieviests pēc vienas no alternatīvām, pārņemot valsts tiešās pārvaldes metodiku vai strādājot pēc alternatīiem pasaules IA praksē pārbaudītiem risinājumiem.

3.9. attēla modelī autore parāda IA iespējamo ieviešanas modeli, piedāvā katras institūcijas galvenos uzdevumus saistībā ar IA ieviešanu, veikšanu, novērtēšanu un uzraudzību, izmantojot valsts tiešās pārvaldes normatìvo aktu regulējumu, tomēr to pielāgojot Latvijas pašvaldību sistēmai.

\section{Pašvaldỉbas domes uzdevumi IA jomā:}

1) izveidot IAS atbilstoši normatīvo aktu prasībām, informēt par to atbildīgo ministriju;

2) noteikt IA darba organizācijas un IA ieteikumu ieviešanas uzraudzības kārtību pašvaldībā;

3) apstiprināt IAS stratēgisko plānu un gada plānu;

4) apstiprināt IA ziņojumus un gada ziņojumus atbildīgajai ministrijai un audita komitejai;

5) iesniegt atbildīgajai nozares ministrijai darbības novērtēšanai nepieciešamo informāciju un dokumentus.

Audita komitejas galvenais mērķis ir palīdzēt vadībai uzraudzìt finanšu ziņošanas procesus, IKS, auditu procesus un atbilstību normatīvo aktu un Ėtikas kodeksa prasībām. Audita komitejā jābūt no trim līdz sešiem locekḷiem, ko ar rīkojumu nosaka atbildīgā nozares ministrija. Audita komitejas sanāksmes notiek vismaz četras reizes gadā, pieaicinot sanāksmēs nozares ministriju, pašvaldību pārstāvjus, IAS vadītājus u. c. Audita komitejas galvenie uzdevumi ir šādi:

1) apstiprināt audita plānu;

2) izvērtēt pašvaldību IAS gada pārskatus un citu informāciju par IAS darbību, sagatavot atzinumus un nosūtīt tos atbildìgajai ministrijai un konkrētajai pašvaldībai; 
3) vērtēt FM iesniegto gada pārskatu par IA darbību pašvaldībās un sniegt savu atzinumu;

4) izvērtēt pašvaldību priekšlikumus IA darba pilnveidošanai vai uzlabošanai un sniegt ieteikumus FM;

5) izvērtēt pašvaldības IAS iesniegto informāciju par IA neatkarības vai objektivitātes ietekmēšanas gadijjumiem un izteikt viedokli FM vai pašvaldības vadībai.

Iekšějā audita departaments/nodaḷa, ko izveido pašvaldības dome saskaņā ar normatīvajiem aktiem. Iekšêjie auditori ir speciālisti ar atbilstošu augstāko izglìtību, sertifikāciju pirmajos divos darba gados un profesionālo pilnveidošanos atbilstoši mācību plānam. Iekšējiem auditoriem ir pieeja visām pašvaldības

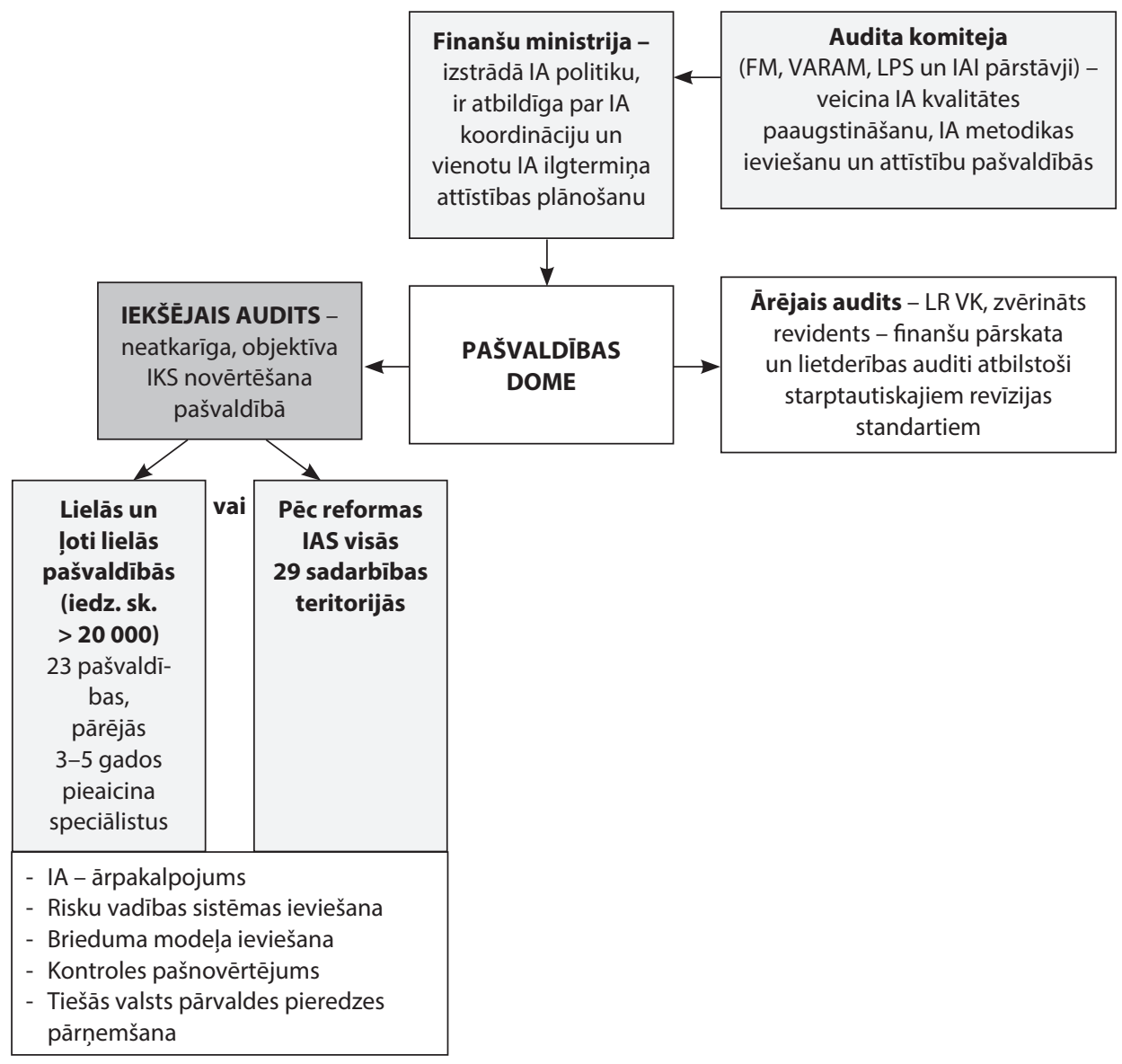

\section{9. attēls. lekšējā audita ieviešanas modelis pašvaldībās}

Avots: autores veidots, pamatojoties uz pētīto literatūru un Latvijas Republikas normatīvajiem aktiem. 
struktūrvienībām, datiem un programmām, tiek nodrošināta auditējamo sadarbība ar iekšējiem auditoriem. IAD/nodaļas galvenie uzdevumi:

1) izstrādā un iesniedz apstiprināšanai pašvaldības domei IA stratēǵisko plānu un gada plānu;

2) veic uz risku novērtējumu balstìtus plānotos IA, kuros sniedz vērtējumu par IK darbïbas atbilstību pašvaldības mērḳiem, pašvaldỉbas finanšu uzskaites un citas informācijas ticamību un pietiekamību, pašvaldỉbas struktūrvienību darbības atbilstību normatīvajiem aktiem, noteiktajām funkcijām un apstiprinātajiem rīcības plāniem, pašvaldības darbības resursu izmaksu efektivitāti, ekonomisko efektivitāti un funkcionālo efektivitāti, resursu sargāšanu no zaudējumiem;

3) sniedz pašvaldíbas domei ieteikumus par nepieciešamajiem uzlabojumiem IKS, uzrauga pašvaldības domes apstiprināto IA ieteikumu ieviešanu;

4) sniedz konsultācijas, lai sekmētu pašvaldības mērķu sasniegšanu;

5) iesniedz pašvaldības domei IAD/nodal̦as darbības gada pārskatu, kurā atbilstoši noteiktajam darba apjomam ietver viedokli par pašvaldības IKS;

6) koordinē iekšējo un ārējo auditoru sadarbỉbu un informācijas apmaiṇu;

7) nosaka iekšējo auditoru mācību vajadzības;

8) nodrošina ar IA saistītā darba izpildes un kvalitātes uzraudzību visos IA posmos. Ja pašvaldības IAD/nodaḷas noteiktos uzdevumus veic viens iekšējais auditors, pastāvīgu IA darba izpildes un kvalitātes uzraudzỉbu visos IA posmos var nodrošināt attiecīgi citas pašvaldības IAD/nodaļas vai pieaicināts ārpakalpojuma speciālists;

9) nodrošina LR VK revīiiju un ārējo auditoru ieteikumu ieviešanas uzraudzību pašvaldībā;

10) IAS vadītājs nosaka šīs struktūrvienības IA veikšanas un darba dokumentu izstrādes metodiku atbilstoši normatīvo aktu kārtībai.

Izstrādātajā pašvaldību IA modelī noteikta loma ir nozares atbildīgajai ministrijai (FM), kuras galvenie uzdevumi ir šādi:

1) izstrādāt IA politiku, kuras mērḳis ir sniegt pārliecību par IKS darbību pašvaldībās;

2) sagatavot un iesniegt audita komitejai apkopoto gada pārskatu par IAS darbību pašvaldībās;

3) koordinēt iekšējo auditoru mācības un profesionālās kvalifikācijas paaugstināšanu;

4) sniegt pašvaldībām konsultācijas IA jomā;

5) vismaz reizi piecos gados novērtēt pašvaldību izveidoto IAS darbību. Ministrijas darbiniekiem attiecīgajā pašvaldībā ir tiesības iepazìties 


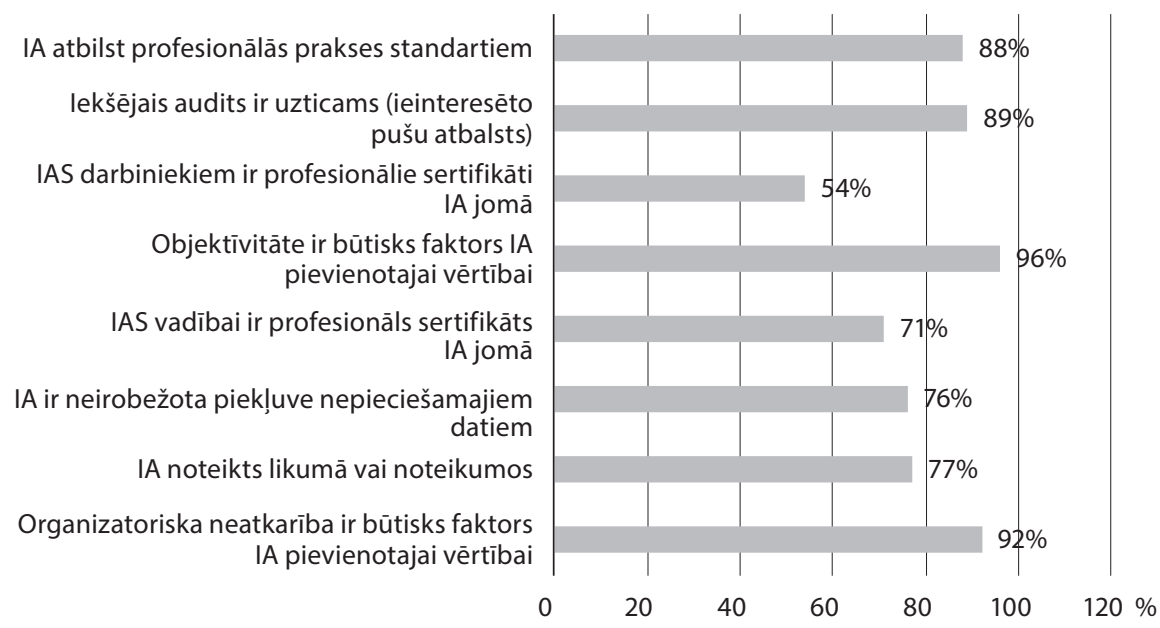

3.10. attēls. Efektīva valsts pārvaldes iekšējā audita pamatelementi atbilstoši starptautiskās IAl aptaujas rezultātiem (2010)

Avots: autores veidots attēls, pamatojoties uz MacRae, Gils (2014).

ar informāciju un dokumentiem, kuri nepieciešami IAS darbības novērtēšanai;

6) pārraudzīt iekšējo auditoru sertifikācijas sistēmu;

7) izstrādāt IA metodikas vadlīnijas.

IAIPF veiktajā 2010. gada pētỉjumā (CBOK), kurā piedalījās 2824 pasaules publiskā sektora iekšêjie auditori no kopumā 13500 aptaujātajiem iekšējiem auditoriem, tika apkopoti deviņi efektīvas valsts pārvaldes IA pamatelementi ${ }^{141}$.

Aptaujātie profesionāḷi uzskata, ka ne visi elementi ir vienādi būtiski, piemēram, 96\% no aptaujātajiem uzskata, ka objektīvi darbinieki nosaka IA efektivitāti, tāpat būtiska loma ir standartu izmantošanai un ieinteresēto pušu atbalstam (tā domā gandrīz $90 \%$ respondentu).

Auditori (sk. 3.10. attēlu) uzskata, ka kompetents personāls un kompetenta vadība ir efektīvas pārvaldes IA pamatelementi. Tikai $8 \%$ no visiem aptaujātajiem iekšējiem auditoriem pasaulē neuzskata, bet visi pārējie apliecina, ka neatkarība ir noteicošais faktors iekšējā audita pievienotajai vērtībai. Apmēram $3 / 4$ jeb 77\% no iekšējiem auditoriem apstiprina, ka IA organizācijā tiek veidots, pamatojoties uz normatīvo aktu prasībām, bet $76 \%$ uzskata, ka vinu IA struktūrvienībai ir pietiekama piekḷuve informācijai.

\footnotetext{
${ }^{141}$ MacRae E, Gils D. Nine Elements Required for Internal Audit Effectiveness in the Public Sector. IIARF, Altamonte Springs, Florida, 2014, p. 48.
} 
Auditori nav snieguši vērtējumu par finansējuma nozīmīgumu, kaut gan aptaujas veidotāji un datu apkopotāji uzskata, ka nepietiekams finansējums var radīt nopietnas problēmas, pildot iekšējo auditoru pienākumus valsts pārvaldē, kam autore pilnībā piekrīt. Vadības un personāla kompetences nozīmīgums noteikti nav diskutējams. Aptaujas dati sniedz arī informāciju par trīs galvenajām, biežāk pieminētajām iekšèjā auditora kompetencēm. Tās ir spēja veicināt IA vērtību organizācijā, komunikācijas prasmes un sekošana līdzi izmaiṇām. Tāpat gandrīz visi aptaujas dalībnieki (izṇemot 4\%) apgalvo, ka darbinieku objektivitāte ir nozīmīgs un būtisks elements IA efektivitātes nodrošināšanā. Gandrīz 90\% uzskata, ka ieinteresēto pušu atbalsts un profesionālie standarti (to piemērošana) ir neatņemams IA efektivitātes nodrošināšanas elements.

Atbilstoši Standartu prasībām IAS vadītājam ir jāizstrādā un jāuztur kvalitātes nodrošināšanas un uzlabošanas programma ${ }^{142}$, tāpat jāveic IAS regulāra iekšèjā novērtēšana un vismaz vienu reizi piecos gados - ārējā novērtēšana.

Pašvaldību IA darbības novērtěšanu, pēc autores domām, var veikt gan atbildīgā ministrija sadarbībā ar audita komiteju, veicot ārējo novērtējumu, gan IAS, izstrādājot pašnovērtējumu atbilstoši LR FM noteiktajiem IAS darbības jomu novērtēšanas kritērijiem ${ }^{143}$ :

1) IA sistēmas darbība, novērtējot IAS sistēmu noteikšanas kārtību, pasākumus, sadarbību ar pašvaldības vadītāju;

2) neatkarība un objektivitāte, novērtējot pašvaldības organizatorisko struktūru, reglamentus, amata aprakstus, plānošanas īstenošanu, darba izpildi un ziņošanu;

3) IAS stratēg̣ija un gada plāns, novērtējot, vai plāni tiek izstrādāti, vai plāni tiek īstenoti, vai ir sabalansēti plānotie resursi, vai tas nodrošina IAS ilgtermiṇa attīstību un spēju sniegt viedokli par IKS;

4) IAS resursi, novērtējot, vai resursi ir pietiekami un profesionālā kvalifikācija ir pietiekama, lai sasniegtu IA funkcijas mērķi;

5) IA process, novērtējot, vai IA metodika nodrošina pietiekamus pierādījumus IKS novērtēšanā, vai trešā persona var izsekot IA procesam;

6) IA rezultāti, novērtējot ziņošanas procesu, tā atbilstību normatīvajiem aktiem, vai ir sniegti ieteikumi IKS darbības pilnveidošanai, vai pašvaldỉbas vadỉba pieņem lēmumus par ieteikumu ieviešanu;

\footnotetext{
${ }^{142}$ IA profesionālās prakses starptautiskie standarti (standarti). IAI. Pieejams: https://global.theiia.org/ translations/PublicDocuments/IPPF-Standards-2017-Latvian.pdfs [skatīts 01.03.2018.]

${ }^{143}$ IA darbības novērtēšana. Pieejams: http://www.fm.gov.lv/lv/sadalas/iekseja_audita_politika/iekseja_ audita_darbibas_novertesana/ [skatīts 01.03.2018.].
} 
7) IA darba izpildes un kvalitātes nodrošināšana, novērtējot, vai pasākumi sekmē nepārtrauktu IAS izaugsmi;

8) IAS sadarbïba ar citiem pārliecības sniedzējiem, novērtējot sadarbību ar ārējiem auditoriem, lai samazinātu audita apjomu un nodrošinātu efektivitāti.

Pamatojoties uz šì pētījuma secinājumiem, kā arī IAI The Common Body of Knowledge starptautisko pētijumu datiem, kas pamatoti ar 14518 respondentu atbildēm no 166 valstīm par IA praksi pasaulē un tajos iekḷautajiem norādījumiem veiksmīgas IA darbības nodrošināšanai, autore ir izstrādājusi pašvaldību IA vērtēšanas pieeju.

Šo pieeju ieteicams izmantot, veicot ārējo novērtējumu gan atbildīgās nozares ministrijas komisijai, audita komitejas pārstāvjiem, gan pašvaldības vadībai un auditējamiem, pieaicinot neatkarīgus ekspertus IA jomā, novērtējot pašvaldības IAS efektivitāti, atbilstību IA regulējošiem normatīvajiem aktiem, Standartiem un labākajai praksei audita jomā.

Vērtējuma procesā pašvaldības IA vērtētājs aizpilda 3.4. tabulu atbilstoši dokumentu pārbaužu, interviju ar iekšêjiem auditoriem, IAS vadību un pašvaldības vadību rezultātiem, 12 faktorus novērtējot ailē "Vērtējums punktos" un piešķirot atbilstošu - punktu skaitu - 2, 1 vai 0 .

1) konkrētā faktora vērtējums ir 2 , un tas nozìmēe $k a$ šajā faktorā $I A$ darbības ir atbilstošas Standartu vai normatīvo aktu prasībām, ir veikti metodikā un plānos noteiktie pasākumi, ja 2.2. faktoram izpildās četri vai pieci nosacījumi; 5.1. faktoram nav atklāti konstatējumu mainī̌sanas gadỉjumi; 6.1. faktors - darbinieki strādā ilgāk nekā divus gadus, pārējie faktori izpildās;

2) konkrētā faktora vērtējums ir 1, un tas nozīmēe, ka šajā faktorā IA darbības ir daḷēji atbilstošas Standartu vai normatìvo aktu prasībām, ir daḷeji veikti metodikā un plānos noteiktie pasākumi, ja 2.2. faktoram izpildās divi vai trīs nosacījumi; 5.1. faktoram nav tiešu pierādijjumu IA konstatējumu mainīšanas gadījumiem ziṇojumos; 6.1. faktors - darbinieki strādā ilgāk par gadu; pārējie faktori izpildās daḷēji;

3) konkrētā faktora vērtējums ir 0 , un tas nozìmēe, ka šajā faktorā konstatētās IA darbības nav atbilstošas Standartu vai normatīvo aktu prasībām, nav veikti metodikā un plānos noteiktie pasākumi, ja 2.2. faktoram izpildās viens nosacijums; 5.1. faktoram ir atklāti IA konstatējumu mainišanas gadījumi; 6.1. faktoru vērtējot ir konstatēts, ka IAS darbinieki mainās un nestrādā ilgāk par gadu; pārējie faktori neizpildās. 
3.4. tabula. Pašvaldību iekšējā audita vērtēšanas pieeja

\begin{tabular}{|c|c|c|c|c|}
\hline Pamatelements* & Faktors** & $\begin{array}{c}\text { Dokuments pārbaudei, } \\
\text { vērtējumam }\end{array}$ & Vērtējums punktos**** & 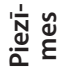 \\
\hline $\begin{array}{l}\text { 1. Organizatoriskā } \\
\text { neatkarība }\end{array}$ & $\begin{array}{l}\text { 1.1. Korekta } \\
\text { IA ieviešana } \\
\text { un paḳlautība } \\
\text { organizācijas } \\
\text { struktūrāa*** }\end{array}$ & $\begin{array}{l}\text { Organizatoriskās struktūras } \\
\text { shēma, rīkojumi, nolikumi }\end{array}$ & $\begin{array}{l}2 \text { - atbilst Standartu un } \\
\text { labās prakses prasībām } \\
1 \text { - dal̄ēji atbilst } \\
\text { Standartu un labās } \\
\text { prakses prasībām } \\
0 \text { - neatbilst Standartu } \\
\text { un labās prakses } \\
\text { prasībām }\end{array}$ & \\
\hline \multirow[t]{3}{*}{$\begin{array}{l}\text { 2. Kompetenta } \\
\text { vadība }\end{array}$} & $\begin{array}{l}\text { 2.1. Pašvaldības } \\
\text { vadības vajadzību } \\
\text { apzināšana un } \\
\text { novērtēšana }\end{array}$ & $\begin{array}{l}\text { Sanāksmju protokoli, } \\
\text { audita plāni }\end{array}$ & $\begin{array}{l}2 \text { - veikta vajadzību } \\
\text { apzināšana } \\
1 \text { - darbības veiktas } \\
\text { dal̦ēji } \\
0 \text { - nav veikta vajadzību } \\
\text { apzināšana }\end{array}$ & \\
\hline & $\begin{array}{l}\text { 2.2. Pašvaldības } \\
\text { vadības un } \\
\text { audita komitejas } \\
\text { konsultēšana }\end{array}$ & $\begin{array}{l}\text { Sanāksmju protokoli, ziņojumi, } \\
\text { kas: } \\
\text { 1) sniedz informāciju par } \\
\text { riskiem; } \\
\text { 2) nodrošina viedokli par } \\
\text { sistēmas darbību kopumā; } \\
\text { 3) paredz izmaksu } \\
\text { optimizāciju, likvidē } \\
\text { kontroles un darbības, } \\
\text { kas nesniedz pievienoto } \\
\text { vērtību; } \\
\text { 4) sniedz padomus, kuriem } \\
\text { jautājumiem pievēršama } \\
\text { regulāra uzmanība; } \\
\text { 5) sniedz kopainu par } \\
\text { kontroles vidi, ziño } \\
\text { par nepieciešamajiem } \\
\text { uzlabojumiem. }\end{array}$ & $\begin{array}{l}2 \text { - izpildīti četri vai pieci } \\
\text { nosacījumi } \\
1 \text { - izpildīti divi vai trīs } \\
\text { nosacījumi } \\
0 \text { - izpildīts viens } \\
\text { nosacījums }\end{array}$ & \\
\hline & $\begin{array}{l}\text { 2.3. IAS vadība ir } \\
\text { kompetenta }\end{array}$ & $\begin{array}{l}\text { Pašvaldības IAS vadītājam } \\
\text { ir atbilstoša līmeña izglītība } \\
\text { un profesionāls sertifikāts IA } \\
\text { jomā }\end{array}$ & $\begin{array}{l}2 \text { - atbilst } \\
1 \text { - dal̦ēji atbilst } \\
0 \text { - neatbilst }\end{array}$ & \\
\hline $\begin{array}{l}\text { 3. Oficiāls } \\
\text { pilnvarojums }\end{array}$ & $\begin{array}{l}\text { 3.1. IA veicina } \\
\text { organizācijas } \\
\text { darbības mērksu } \\
\text { sasniegšanu }\end{array}$ & $\begin{array}{l}\text { IA piedalīšanās pašvaldības } \\
\text { gada pārskata sagatavošanā. } \\
\text { Konsultācijas, interviju } \\
\text { protokoli, IA darba } \\
\text { dokumenti, ziņojums }\end{array}$ & $\begin{array}{l}2 \text { - atbilst } \\
1 \text { - dal̦ēji atbilst } \\
0 \text { - neatbilst }\end{array}$ & \\
\hline \multirow{2}{*}{$\begin{array}{l}\text { 4. Neierobežota } \\
\text { piekl̦uve } \\
\text { informācijai un } \\
\text { resursiem }\end{array}$} & $\begin{array}{l}\text { 4.1. Datu analīzes } \\
\text { izmantošana IA }\end{array}$ & IA darba dokumenti, zin,ojumi & $\begin{array}{l}2 \text { - atbilst } \\
1 \text { - dal̦ēji atbilst } \\
0 \text { - neatbilst }\end{array}$ & \\
\hline & $\begin{array}{l}\text { 4.2. IT risku } \\
\text { apzināšana IA } \\
\text { plānos }\end{array}$ & IA plānos iekḷautas IT sistēmas & $\begin{array}{l}2 \text { - atbilst } \\
1 \text { - dalēji atbilst } \\
0 \text { - neatbilst }\end{array}$ & \\
\hline
\end{tabular}




\begin{tabular}{|c|c|c|c|c|}
\hline Pamatelements* & Faktors** & $\begin{array}{c}\text { Dokuments pārbaudei, } \\
\text { vērtējumam }\end{array}$ & Vērtējums punktos**** & $\frac{1}{\stackrel{N}{\alpha}} \stackrel{\varrho}{\varepsilon}$ \\
\hline $\begin{array}{l}\text { 5. Objektīvi } \\
\text { darbinieki }\end{array}$ & $\begin{array}{l}\text { 5.1. Patiesas } \\
\text { informācijas } \\
\text { sniegšana IA } \\
\text { zin,ojumos }\end{array}$ & $\begin{array}{l}\text { IA ziņojumi, } \\
\text { intervijas ar auditoriem } \\
\text { (IAS vadītājs, auditējamās } \\
\text { struktūrvienības vadītājs vai } \\
\text { augstākā vadība likusi mainīt } \\
\text { IA konstatējumus) }\end{array}$ & $\begin{array}{l}2 \text { - nav atklāti } \\
\text { konstatējumu } \\
\text { mainīšanas gadījumi } \\
1 \text { - nav tiešu } \\
\text { pierādījumu } \\
\text { konstatējumu } \\
\text { mainīšanas gadījumiem } \\
0 \text { - konstatējumu } \\
\text { mainīšanas gadījumi } \\
\text { atklāti }\end{array}$ & \\
\hline \multirow[t]{2}{*}{$\begin{array}{l}\text { 6. Kompetents } \\
\text { personāls }\end{array}$} & $\begin{array}{l}\text { 6.1. Motivēta un } \\
\text { profesionāla IA } \\
\text { komanda }\end{array}$ & $\begin{array}{l}\text { lekšējo auditoru darba līgumi, } \\
\text { CV, apmācību profesionālās } \\
\text { kvalifikācijas sertifikāti }\end{array}$ & $\begin{array}{l}2 \text { - strādā ilgāk par } \\
\text { diviem gadiem } \\
1 \text { - darbinieki strādā } \\
\text { ilgāk par gadu } \\
0 \text { - darbinieki mainās, } \\
\text { nestrādā ilgāk par vienu } \\
\text { gadu }\end{array}$ & \\
\hline & $\begin{array}{l}\text { 6.2. lekšējā } \\
\text { auditora } \\
\text { profesionālā } \\
\text { pilnveide, mācības }\end{array}$ & IAS darbinieku mācību plāns & $\begin{array}{l}2 \text { - tiek plānotas un } \\
\text { ìstenotas regulāras } \\
\text { mācības (atbilst) } \\
1 \text { - tiek īstenotas } \\
\text { neregulāras mācības } \\
\text { (dalēeji atbilst) } \\
0 \text { - netiek plānotas } \\
\text { mācības (neatbilst) }\end{array}$ & \\
\hline $\begin{array}{l}\text { 7. leinteresēto } \\
\text { pušu atbalsts }\end{array}$ & $\begin{array}{l}\text { 7.1. Progresīvas } \\
\text { risku vadības } \\
\text { prakses attīstīšana }\end{array}$ & $\begin{array}{l}\text { IA plāni, to aktualizācijas } \\
\text { biežums, saskaṇojums ar } \\
\text { pašvaldības stratēǵisko plānu }\end{array}$ & $\begin{array}{l}2 \text { - veikti risku vadības } \\
\text { pilnveidošanas } \\
\text { pasākumi } \\
1 \text { - dal̦ēji izmantota } \\
\text { risku vadības prakse } \\
0 \text { - nav izmantota risku } \\
\text { vadības prakse }\end{array}$ & \\
\hline $\begin{array}{l}\text { 8. Profesionālie } \\
\text { audita standarti }\end{array}$ & $\begin{array}{l}\text { 8.1. Standartu } \\
\text { pamatprincipu } \\
\text { ievērošana }\end{array}$ & IA darba dokumenti, ziņojums & $\begin{array}{l}2 \text { - ir ievēroti pilnībā } \\
1 \text { - ir ievēroti dalēeji } \\
0 \text { - nav ievēroti }\end{array}$ & \\
\hline
\end{tabular}

Avots: autores veidota tabula:

* atbilstoši 2010. gada IAIPF CBOK aptaujas datiem;

** adaptēti saskaṇā ar 2015. gada IAIPF CBOK globālo aptauju;

*** atbilstoši pamatelementam "organizatoriskā neatkarība";

**** vērtējuma piešḳiršana. 
Kad vērtējums ir izdarīts, vērtētājs saskaita iegūtos punktus un identificē IA darba novērtējuma atbilstošo grupu:

1) ja kopējais vērtējums punktos ir no 12 līdz 24 punktiem - IA darbība tiek nodrošināta veiksmīgi. IA funkcija ir piemērs citām IAS. Auditā piemērotās metodes un labo praksi kā paraugu var izmantot citas IAS (nevienā faktorā vērtējums nav 0, visi 12 faktori saṇēmuši vērtējumu 1 vai 2$)$;

2) no 7 līdz 11 punktiem - IA darbības nodrošinājums tiek vērtēts kā daḷēji veiksmīgs. IA ir funkcionējošs, bet konstatētie trūkumi ietekmē IA funkcijas mērḳa sasniegšanu (vismaz septiṇi analizētie faktori saṇēmuši vērtējumu 1);

3) no 0 līdz 6 punktiem - IA darbība nedod pievienoto vērtību. IA funkcija ir pilnveidojama, konstatētie trūkumi kavē sasniegt IA funkcijas mērḳi (tikai no viena faktora līdz sešiem faktoriem ir vidējais vai augstākais vērtējums 1 vai 2 ).

Lai aprobētu izstrādāto pieeju, tika izmantota ekspertu metode. 2018. gada maijā autorei savu viedokli un komentārus sniedza deviņi eksperti:

1) Iveta Reinholde, asoc. prof. LU Politikas zinātnes nodaļas vadītāja, Eiropas Padomes Reǵionālo un vietējo pašvaldību kongresa neatkarīgā eksperte, IAI Latvijas nodalas valdes locekle;

2) Iveta Cipruse, Rēzeknes pilsētas domes IA un kapitālsabiedrību pārraudzības nodalıas vadìtāja-revidente;

3) Aivars Valters, Valsts Kancelejas IAS konsultants;

4) Indra Ozola, Valsts Kancelejas IAS vadìtāja;

5) Laila Lazdāne, FM IAD direktores p. i.;

6) Elīna Gabranova, FM IAD Iekšējā audita nodaļas vadītāja;

7) Nata Lasmane, FM ES fondu revīzijas departamenta direktore;

8) Olga Guza, FM ES fondu revizijas departamenta direktores vietniece;

9) Kārlis Majevskis, IAI Latvijas nodaḷas valdes priekšsēdētājs, Kesko-K Group IA vadìtājs.

Apkopojot ekspertu viedokḷıs un komentārus par izstrādāto vērtēšanas pieeju, secināms: lielākā daļa uzskata, ka kopumā autores izstrādātā pašvaldību IA vērtēšanas pieeja ir izmantojama.

Viena eksperta skatījumā, pašvaldības varētu izmantot kādas valsts pārvaldes iestādes izstrādāto pašnovērtējuma pieeju, kam autore piekrīt, jo kā vienu no IA funkcijas risinājumiem autore piedāvā pašvaldībām pārņemt valsts tiešās pārvaldes IA metodiku, pielāgojot to pašvaldību vajadzībām.

Trīs no ekspertiem iesaka izmantot arī citus faktorus, kam autore piekrìt. Divi eksperti iesaka pamatelementam "oficiāls pilnvarojums" vērtēt 
likumā/reglamentā noteiktos pilnvarojumus, tāpat arī veikto auditu proporciju (atbilstības auditi, efektivitātes auditi); raksturojot pamatelementu "objektīvi darbinieki", eksperti iesaka vērtēt darbinieku ètisko uzvedību, prasmi piemērot to praksē; savukārt pamatelementam "kompetents personāls" eksperti iesaka vērtēt ieteikumu ieviešanu, t. sk. atcelto ieteikumu ipatsvaru.

Divi no ekspertiem uzskata, ka vērtējumā jāiekḷauj visi IA standarti, kam autore piekrīt dậ̣ji, jo sākotnējā IA ieviešanas posmā nav iespējams ieviest visus standartus, taču jāvērtē galvenie posmi, bet astoņus pamatelementus autore sevis izstrādātajai pieejai n̦ēmusi par pamatu atbilstoši starptautiskā pētỉjumā apkopotajiem valsts pārvaldes profesionāḷu viedokḷiem. Visu standartu iekḷaušana pašvaldības IA vērtēšanā, autoresprāt, iespējama pēc pirmo piecu gadu IA funkcijas pastāvēšanas, kad būtu auditētas visas sistēmas, bet iekšējie auditori ieguvuši profesionālos sertifikātus un atbilstošu kvalifikāciju, lai pildītu pienākumus atbilstoši Standartiem.

Viens no ekspertiem uzskata, ka pieejā trūkst dažu elementu saistībā ar gada plānošanu, ko nevar uztvert nepārprotami, jo IA plāni ir iekḷauti elementu "kompetenta vadība", "neierobežota piekḷuve informācijai un resursiem", "ieinteresēto pušu atbalsts" un "profesionālie audita standarti” vērtēšanā. Eksperts arī norādījis, ka izstrādātā pieeja neietver konstatēto problēmu ieviešanas pārraudzību (follow-up), kas, autores ieskatā, ir iekḷauts faktorā "Standartu pamatprincipu ievērošana”. Saskaņā ar Standartu būtỉbu tieši šajā elementā ir ietverti visi IA procesi, kur ir gan darba uzdevumu plānošana, darba uzdevuma izpilde, gan rezultātu paziņošana un darba gaitas pārraudzība.

Autore pierìt ekspertu ieteikumiem un uzskata, ka pamatelementu novērtējums ir papildināms un vērtētājs var iekḷaut papildu dokumentus procesu vērtēšanā katrā individuālā gadỉjumā atkarībā no konkrētās pašvaldỉbas specifiskajiem faktoriem (īstenots starptautisks projekts, veiktas būtiskas teritoriālas izmainas, rekonstrukcijas u. c.).

IAS saskaṇā ar Standartiem sniedz pievienoto vērtību organizācijai un tās ieinteresētajām pusēm, ja tāejejādi nodrošina objektīvu un pietiekamu pārliecību, kā arī veicina pārvaldības, riska vadības un kontroles procesu efektivitāti un lietderību. Intervijās ar pašvaldības vadību, ar pašvaldības struktūrvienību vadītājiem iespējams noskaidrot, vai iekšējais auditors ir pietiekami kompetents, kas ir viens no būtiskajiem iekšèjā audita pievienotās vērtības elementiem.

Lai noteiktu pašvaldības IA pievienoto vērtību, pamatojoties uz teorētisko analīzi, autore izstrādājusi pašvaldību IA pievienotās vērtības jeb ieguvumu sarakstu (3.5. tabula). Autore piedāvā šo sarakstu papildināt pēc nepieciešamības ar citiem katrai pašvaldībai specifiskiem un būtiskiem ieguvumiem. 


\section{5. tabula. Pašvaldību IA pievienotās vērtības (ieguvumu) saraksts}

\begin{tabular}{|c|c|c|}
\hline $\begin{array}{l}\text { Nr. } \\
\text { p. k. }\end{array}$ & IA radītā pievienotā vērtība (ieguvums) pašvaldībā & $\begin{array}{c}\text { Eksperta } \\
\text { vērtējums }\end{array}$ \\
\hline 1. & Pašvaldības vadības procesu pilnveidošana & 012 \\
\hline 2. & Bāriṇtiesas darbības procesu pilnveidošana & 012 \\
\hline 3. & Finanšu procesi: & \\
\hline 3.1. & Pašvaldības budžeta plānošanas un izpildes kontroles procesa pilnveidošana & 012 \\
\hline 3.2. & Grāmatvedības uzskaites procesu pilnveidošana & 012 \\
\hline 3.3. & Finanšu atskaišu sagatavošanas procesa uzlabošana & 012 \\
\hline 3.4. & Gada pārskata sagatavošanas procesa pilnveidošana & 012 \\
\hline 3.5. & Sadarbības ar Valsts kasi veicināšana & 012 \\
\hline 3.6. & Sadarbības ar ārējo auditu veicināšana & 012 \\
\hline 4. & Lietvedíba & \\
\hline 4.1. & $\begin{array}{l}\text { Vienotas lietvedības darba un dokumentu } \\
\text { aprites procesu pilnveidošana pašvaldībā }\end{array}$ & 012 \\
\hline 4.2. & $\begin{array}{l}\text { Domes un pašvaldības organizatoriskā un tehniskā darba nodrošināšanas un } \\
\text { koordinēšanas procesu pilnveidošana }\end{array}$ & 012 \\
\hline 4.3. & $\begin{array}{l}\text { Domes un pašvaldības administrācijas dokumentu uzkrāšanas un uzglabāšanas, } \\
\text { arhīva darba nodrošināšanas funkcijas pilnveidošana }\end{array}$ & 012 \\
\hline 5. & Personālvadība & \\
\hline 5.1. & Personāla atlases procesu pilnveidošana & 012 \\
\hline 5.2 & Personāla lietvedības uzlabošana & 012 \\
\hline 5.3. & Pašvaldības darbinieku vērtēšanas procesa pilnveidošana & 012 \\
\hline 6. & Juridiskā atbalsta procesu pilnveidošana & 012 \\
\hline 7. & lepirkumu procesi & \\
\hline 7.1. & Efektīvāku iepirkumu plānu nodrošināšana & 012 \\
\hline 7.2 & lepirkumu procedūru pilnveidošana & 012 \\
\hline 7.3. & $\begin{array}{l}\text { Domes dibināto iestāžu / institūciju atbalsta un konsultēšanas funkcijas } \\
\text { iepirkumu jomā pilnveidošana }\end{array}$ & 012 \\
\hline 8. & Būvvaldes darba procesu pilnveidošana & 012 \\
\hline 9. & Dzimtsarakstu nodaḷas procesu pilnveidošana & 012 \\
\hline 10. & Ekonomiskāka projektu īstenošana & 012 \\
\hline 11. & Darbinieku izpratnes veicināšana par pašvaldības procesu pilnveidošanu & 012 \\
\hline 12 & Pašvaldības kapitālsabiedrības & \\
\hline 12.1. & Budžeta plānošanas un izpildes procesu pilnveidošana & 012 \\
\hline 12.2. & Grāmatvedības procesu pilnveidošana & 012 \\
\hline 12.3. & Finanšu pārskatu kvalitātes uzlabošana & 012 \\
\hline 13. & * & 012 \\
\hline 14. & * & 012 \\
\hline
\end{tabular}

Avots: autores veidota tabula.

* Papildināms pēc nepieciešamības. 
Novērtējot katras pašvaldības IA pievienoto vērtību jeb ieguvumus novērtētājam (pašvaldības vadībai vai ārējam novērtētājam, IAS novērtētājam), jāsniedz vērtējums 0,1 vai 2 šãdi: 0 - ja ieguvums neuzlabo pašvaldības darbību; 1 - ja ieguvums nedaudz uzlabo pašvaldỉbas darbïbu; un 2 - ja ieguvums būtiski uzlabo pašvaldības darbu.

Autore iesniedza ekspertiem novērtēšanai arì pētījumā izstrādāto pašvaldības IA pievienoto vērtību jeb ieguvumu sarakstu un 2018. gada maijā saṇēma iepriekšminēto deviņu ekspertu vērtējumu. Divi eksperti neizteica skaitlisko vērtējumu pašvaldību IA pievienotās vērtības jeb ieguvumu pašvaldības procesu uzlabošanā, viens no ekspertiem nenovērtēja četrus procesus, savukārt seši no deviņiem ekspertiem novērtēja autores piedāvāto pašvaldību IA pievienoto vērtību jeb ieguvumus visos minētajos procesos.

Pēc ekspertu domām, lielāko IA pievienoto vērtību sniedz jeb būtiski uzlabo tie ieguvumi, kas saistīti ar pašvaldības vadības, budžeta plānošanas un izpildes kontroles pilnveidošanu, vienotas lietvedības darba un dokumentu aprites nodrošināšanu, domes un pašvaldības organizatoriskā un tehniskā darba koordinēšanas uzlabošanu, kā arī iepirkumu procesu pilnveidošanu un efektīvāku iepirkumu plānu nodrošināšanu. Savukārt vismazāko vērtējumu eksperti piešķīuši darbinieku izpratnes veicināšanai par pašvaldības darbu pilnveidošanai, juridiskā atbalsta procesu un sadarbïbas ar Valsts kasi veicināšanai. Lỉdz ar to autores izstrādātā pieeja ir aprobēta ekspertu novērtējuma rezultātā un izmantojama pašvaldỉbas IA ieguvumu novērtēšanai.

\section{3. nodal̦as kopsavilkums}

No sabiedrības viedokḷa ir nozīmīgi, vai institūcija valsts pārvaldē rīkojusies lietderīgi, efektīvi un likumīgi. Arī IA jomā tiek vērtēta efektivitāte. Ar šādu mērķi autore analizējusi sešu ekspertu aptaujas. Galvenie ekspertu viedokḷi raksturojami ar šādiem izteikumiem: Latvijas valsts tiešajā pārvaldē IA ir efektīvs, balstīts uz risku vadības novērtēšanas pieeju; IA ir uzticams un rada pievienoto vērtību; IA sistēma kopumā darbojas, taču ir nepieciešami daži uzlabojumi trūkumu novēršanai. Ekspertu vērtējumā neatkarība ir galvenais faktors IA pievienotās vērtības radīšanā, IA sniedz sistemātisku efektivitātes un risku vadības novērtēšanas pieeju.

Joprojām IA netiek pienācīgi novērtēts, un daḷa atbildības par to ir jāuzņemas iestāžu vadītājiem. Auditoru zināšanas un pieredze, ko savukārt ietekmē darbinieku mainība, būtiski ietekmē IA kvalitāti valsts tiešajā pārvaldē. Auditoru skaits ne vienmēr ietekmē plānu izpildi; l̦oti būtiska ir plānošana un efektivitāte, kas ir neatņemama jebkura procesa sastāvdaḷa, tostarp arī IA. 
Būtiska loma efektivitātes nodrošināšanā ir katra darbinieka individuālajām īpašībām un prasmēm strādāt ar liela apjoma informāciju. Svarīgs iemesls IA sistēmas nepilnībām valsts tiešās pārvaldes iestādēs un ministrijās ir zema darbinieku motivācija attīstīties un izglìtoties.

Jau 2005. gadā, vērtējot IA sistēmu Latvijā, ārvalstu eksperti norādīja, ka pašvaldībās būtu jāievieš IA, nodrošinot LR VK auditoriem iespēju izmantot iekšējo auditoru darba rezultātu, kā arī paaugstināt sistēmas kvalitāti un efektivitāti, atbrīvojoties no funkciju dublēšanās.

Jau vairākus gadus LR VK revidenti finanšu revīzijā par Pašvaldību gada pārskata daḷu un likumības/lietderības revīiijās pašvaldībās ir konstatējusi dažādu normatīvo aktu pārkāpumus. Revidenti aprēķinājuši, ka dažos novados veidojas vairāku grāmatvedības darbinieku slodžu rezerve un potenciālais ietaupījums gadā varētu būt vismaz 43000 EUR. Autore uzskata, ka minētās rezerves ir iespēja pašvaldībā vai centralizēti sadarbības teritorijā nodarbināt iekšējos auditorus, kas varētu uzsākt un pakāpeniski sakārtot iekšejēās kontroles procesus.

Autore piedāvā divas alternatīvas Latvijas pašvaldību IA sistēmas izveidei:

1) IA struktūrvienība izveidojama lielās un ḷoti lielās pašvaldībās, IA tiek plānoti katru gadu, un iekšejie auditori katru gadu sagatavo ziņojumu atbildīgajai ministrijai, bet pārējās pašvaldībās jānodrošina IA veikšana reizi 3-5 gados, atkarībā no prioritātes aptverot visas pašvaldības sistēmas;

2) pēc pašvaldību reformas īstenošanas par 29 apriņ̧̧̧u jeb pašvaldības sadarbības teritorijām ieviest IAS visos pašvaldību 29 sadarbības teritoriju jeb apriņķu centros.

Normatīvajos aktos ietvertajam IA regulējumam jābūt elastīgam, un pašvaldībām jālauj izvēlēties kādu no pasaulē un Latvijā pārbaudītām praktiskām pieejām IA funkcijas īstenošanā:

1) valsts tiešās pārvaldes IA metodikas pārṇemšana, pielāgojot pašvaldību vajadzībām;

2) iekšèjais audits kā ārpakalpojums;

3) risku vadǐšanas iespējas;

4) brieduma model̦a ieviešana;

5) kontroles pašnovērtējums.

Autore piedāvā pašvaldību IA ieviešanas modeli, kurā ietverti katras institūcijas galvenie uzdevumi saistībā ar IA ieviešanu, veikšanu, novērtēšanu un uzraudzību, izmantojot valsts tiešās pārvaldes normatīvo aktu regulējumu un pielāgojot Latvijas pašvaldību sistēmai. 
Pamatojoties uz teorētisko pētījumu, autore izmantoja šādus IA vērtēšanas pamatelementus: organizatoriskā neatkarība, kompetenta vadỉba, oficiāls pilnvarojums, neierobežota piekḷuve informācijai un resursiem, objektīvi darbinieki, kompetents personāls, ieinteresēto pušu atbalsts un profesionālie iekšējā audita standarti. Tas l̦āvis izstrādāt jaunu pašvaldību IA vērtēšanas pieeju, kas izmantojama, veicot ārējo novērtējumu. To apstiprinājuši ekspertu vērtējumi: seši eksperti uzskata, ka vērtēšanas pieeja izmantojama pašvaldību IA vērtēšanā, trīs eksperti uzskata, ka izstrādātā pieeja ir jāpapildina, taču to var piemērot katras konkrētās novērtēšanas gadijumā.

Autores pētỉjumā uzrādītā novitāte ir arī pašvaldību IA sniegtās pievienotās vērtības jeb ieguvumu saraksts, kas ir l̦oti nozīmīgs elements IA funkcionēšanas novērtēšanā. Saskaṇā ar ekspertu vērtējumu lielākā IA pievienotā vērtība jeb ieguvums ir pašvaldības vadības, budžeta plānošanas un izpildes kontroles uzlabošana, lietvedības un dokumentu aprites procesu pilnveidošana, kā arī domes un pašvaldības organizatoriskā un tehniskā darba veikšanas, iepirkumu procesu, personāla lietvedības un iepirkumu procesu pilnveidošana. 


\section{NOBEIGUMS}

IA pirmsākumi meklējami vienlaikus ar grāmatvedības rašanos jau pirms mūsu ēras, savukārt mūsdienu IA ir attīstījies kopš IAI dibināšanas ASV 1941. gadā.

Autore savā pètījumā konstatējusi, ka IA un auditora profesijas attīstībā ievērojamu ieguldījumu devuši daudzi pētījumi dažādās pasaules valstīs, analizējot IA metodiku, IA pievienoto vērtību, audita efektivitāti, iekšējā un ārējā audita sadarbību, audita komitejas lomu u. c. Pētot IA attīstību Eiropas valstīs, autore secinājusi, ka valstis dažādi ievieš, interpretē un skaidro IA un iekšējās kontroles procesus, tāpat katrai valstij ir sava prakse un atšķirīgas IA funkcijas, ko citas valstis var izmantot kā labākās prakses paraugu.

Analizējot Latvijas valsts pārvaldes iekšējo auditu, autore secinājusi, ka samērā augsta ir auditoru mainība, kas ietekmē iekšêjā audita kvalitāti, tāpat Iekšèjā audita padome pēdējo gadu atzinumos akcentē esošã iekšèjā audita kompetences un efektivitātes nepietiekamību, kā arī atalgojuma problēmu, kas izskaidrojams ar pašreizējās Latvijas Republikas augstākās izglìtības sistēmas nepilnīgajām iespējām IA jomā, jo faktiskā iekšèjā auditora izglìtošana notiek tikai darba procesā.

Ekspertu aptaujas rezultāti liecina, ka neatkarība ir viens no galvenajiem faktoriem IA pievienotās vērtības radī̌nanā, un Latvijas valsts tiešās pārvaldes IA sniedz sistemātisku efektivitātes un risku vadības novērtēšanas pieeju, taču tiek uzskatīts, ka IA metodikai ir nepieciešami uzlabojumi.

Jau 2005. gadā, vērtējot IA sistēmu Latvijā, ārvalstu eksperti norādīja, ka pašvaldībās būtu jāievieš IA funkcija, nodrošinot LR VK auditoriem iespēju izmantot iekšêjo auditoru darba rezultātu, kā arī nodrošināt sistēmas kvalitāti un efektivitāti, atbrīvojoties no funkciju dublēšanās. Autore konstatējusi, ka Latvijas pašvaldību iekšējie auditori savā darbā izmanto Latvijas Republikas normatīvos aktus un pašvaldību saistošos noteikumus, Standartus un savu izstrādāto audita metodiku. 71,4\% no iekšējiem auditoriem uzskata, ka ir nepieciešamas izmaiņas normatīvajos aktos, tomēr vairāki auditori uzskata, ka IA var darboties kā līdz šim - brīvprātīgi. Daži iekšejjie auditori savā darbā joprojām izmanto 
Starptautiskos revīzijas standartus, kas ir ārējiem revidentiem saistošs pamatdokuments. Pašvaldību iekšējie auditori strādā, ievērojot atšķirīgas metodes, bet dažās pašvaldībās IA veikšanas metodikas vispār nav.

Pētījumā iekḷautās statistiskās datu analīzes rezultāti par laika periodu no 2013. gada līdz 2016. gadam parādīja, ka Latvijas pašvaldībās ar IA un pašvaldībās bez IA ieṇēmumu un pašvaldību aktīvu apjoms būtiski atšksiras. Analizējot Latvijas statistiskos reǵionus, vērojama sakarība: pašvaldībās, kurās nav IA, vidējās ieņēmumu summas un aktīvu apjoms ir mazāks nekā tajās pašvaldībās, kurās darbojas IA.

Ekspertu vērtējumā, autores veidotajā pašvaldību IA pievienotās vērtības jeb ieguvumu sarakstā nozīmīgākie elementi ir pašvaldības vadỉbas, budžeta plānošanas un izpildes kontroles uzlabošana, vienotas lietvedỉbas darba un dokumentu aprites nodrošināšana, domes un pašvaldības organizatoriskā un tehniskā darba veikšana un koordinēšana, kā arī iepirkumu procesu pilnveidošana un personāla vadības sistēmu efektīvāka nodrošināšana.

Pamatojoties uz veikto pētījumu un tam atbilstošajiem secinājumiem, autore ir izstrādājusi priekšlikumus, ar kuriem būtu iespējams uzlabot valsts pārvaldes IA funkcijas kvalitāti un ieviest vienotu IA funkciju Latvijas pašvaldībās.

Eiropas Komisijai veidot vadlīnijas regulāru pārskatu sagatavošanai par valsts pārvaldes un pašvaldību IAS, ziņojumā ietverot kvantitatīvos datus par IA, kas būtu salīdzināmi visās ES valstīs, piemēram, personāla kvalifikāciju (darba stāžu, sertificēto iekšèjo auditoru skaitu), IA procesa efektivitāti (noslēgto IA skaitu, gada plāna izpildi procentos, termiņu ievērošanu audita ziņojumu iesniegšanai), IAS pievienoto vērtību (ieviesto ieteikumu īpatsvaru, auditoru dienu īpatsvaru, IAS vadītāja novērtējumu, ārējās novērtēšanas rezultātu, IA padomes novērtējumu u. c).

Latvijas Zinātṇu akadēmijas Terminologijas komisijai iekḷaut termina “iekšējais audits" skaidrojumu akadēmiskajā terminu datubāzē, priekšlikumā ietverot šādu Iekšèjā auditoru institūta definīciju, kas vispilnīgāk raksturo IA: "Iekšejjais audits ir neatkarīga, objektīva pārliecības radī̌ana un konsultēšana, lai palielinātu organizācijas vērtību un pilnveidotu tās darbības. Iekšējais audits palīdz organizācijai sasniegt tās mērḳus, ieviešot sistemātisku, disciplinētu pieeju, lai novērtētu un pilnveidotu riska vadības, kontroles un pārvaldības procesu efektivitāti organizācijā vai iestādē risku vadības, kontroles un pārvaldes procesos."

Finanšu ministrijai kā atbildīgajai par IA koordināciju un vienotu IA ilgtermiņa attīstības plānošanu Latvijas valsts pārvaldes IA attīstības veicināšanai izskatīt iespēju pārṇemt dažu Eiropas valstu pieredzi šajā jomā: no Igaunijas 
valsts pārvaldes - IA sistēmas ieviešanas pašvaldībās noteikšanu normatīvajos aktos; no Lietuvas un Ungārijas valsts pārvaldes - sertifikācijas programmu iekšējiem auditoriem ar apmācības moduļiem, pieaicinot universitātes profesorus un praktiķus; no Polijas valsts pārvaldes - audita komitejas izveidošanu katrā ministrijā; no Maltas valsts pārvaldes - iekšējā un ārējā audita sadarbības šḳēršlu risinājumu, lai tiktu veicināta sadarbība labākai komunikācijai, kas noteikta normatīvajos aktos, tiktu piešķirti pietiekami resursi, notiktu konsultēšanas darbs; no Lielbritānijas valsts pārvaldes - iekšējā un ārējā audita sadarbība, daloties ar audita stratēǵijām, plāniem, samazinot audita slogu uz organizāciju; no Kipras valsts pārvaldes - iekšējo auditoru specializēšanās konkrētās jomās; izstrādāt grozijumus MK 30.04.2013. noteikumos Nr. 238 "Iekšējo auditoru sertifikācijas kārtība” par iekšējo auditoru profesijas standarta ieviešanu valstī, kas noteiktu stingru sertifikāciju un auditoru specializēšanos konkrētās jomās: IT, personālvadība, finanses un budžets, grāmatvedības uzskaite, projekti u. c.

Vides aizsardzības un reǵionālās attīstības ministrijai sadarbībā ar Finanšu ministriju izstrādāt grozījumus likumā "Par pašvaldībām" un Iekšējā audita likumā tā, lai likumi attiektos uz ministrijām, iestādēm un pašvaldībām pēc viena no diviem autores piedāvātajiem scenārijiem: 1) IA struktūrvienība izveidojama lielās un l̦oti lielās pašvaldībās (iedzīvotāju skaits pārsniedz 20 000), pārējās pašvaldībās jānodrošina IA veikšana vismaz reizi piecos gados; 2) ieviest IAS visās pašvaldību 29 sadarbības teritoriju jeb apriṇķu centros. Izstrādāt "Rokasgrāmatu Latvijas pašvaldību iekšejjā audita struktūrvienībām” ar iespējamām IA veikšanas pieejām: valsts tiešās pārvaldes metodikas pārṇemšana; ārpakalpojuma pieeja; risku vadīšanas pieeja; brieduma modeḷu izmantošana; kontroles pašnovērtējuma ieviešana, iekḷaujot autores izstrādāto pašvaldību IA vērtēšanas pieeju.

Latvijas augstākajās mācību iestādēs izstrādāt studiju kursus, kas nepieciešami iekšējā audita sistēmas apguvei dažādos aspektos, proti, "Valsts pārvaldes iekšējais audits", "Pašvaldību iekšējais audits", "Publiskā sektora risku vadība" vai "Pašvaldību iekšējā kontrole", kursu realizēšanu veidojot sadarbībā ar profesionāliem. To saturs dotu iespēju jaunajiem speciālistiem sagatavoties iekšèjā audita darbam valsts pārvaldē un pašvaldībās.

Latvijas pašvaldību vadītājiem, novērtējot IA lomu iekšējās kontroles sistēmas sakārtošanā, pēc nepieciešamības rast iespēju izveidot IAS savā pašvaldībā ar autores piedāvāto IA ieviešanas modeli un IA vērtēšanas pieeju. 


\section{PATEICİBAS}

Autore izsaka vislielāko pateicību Latvijas Universitātes profesorei Dr. oec. Intai Brūnai par ieteikumiem, iedrošinājumu, kritiku un veltīto laiku monogrāfijas tapšanā.

Liels paldies redaktorei Sandrai Priedītei par sapratni un literāro rediǵēšanu. Liels paldies maketētājai Andrai Liepiṇai par pacietību un grāmatas noformējumu.

Liels paldies gimenei par atbalstu un iedrošinājumu. 


\section{ABREVIATŪRU SARAKSTS}

\begin{tabular}{|c|c|}
\hline $\mathrm{BOK}-$ & The Common Body of Knowledge \\
\hline $\mathrm{COSO}-$ & The Committee of Sponsoring Organizations of the Treadway Commission \\
\hline CSP - & Centrālā statistikas pārvalde (Central Statistical Bureau of Latvia) \\
\hline ECIIA - & European Confederation of Institutes of Internal Auditing \\
\hline $\mathrm{FM}-$ & Finanšu ministrija (Ministry of Finance) \\
\hline IA - & iekšejais audits (Internal audit) \\
\hline IAI $(I I A)-$ & Iekšējo auditoru institūts (The Institute of Internal Auditors) \\
\hline $\mathrm{IAD}-$ & Iekšējā audita departaments (Internal Audit Department) \\
\hline F) & $\begin{array}{l}\text { Iekšèjo auditoru institūta Pētījumu fonds (The Institute of Internal } \\
\text { Auditors Research Foundation) }\end{array}$ \\
\hline IAS - & ruktūrvienība (Internal Audit Unit) \\
\hline IKS (ICS) - & iekšējās kontroles sistēma (Internal control system) \\
\hline IT - & informācijas tehnologijas (Information Technology) \\
\hline KNAB - & $\begin{array}{l}\text { Korupcijas novēršanas un apkarošanas birojs (Corruption Prevention and } \\
\text { Combating Bureau of Latvia) }\end{array}$ \\
\hline LR VK - & $\begin{array}{l}\text { Latvijas Republikas Valsts kontrole (The State Audit Office of Republic of } \\
\text { Latvia) }\end{array}$ \\
\hline LPS - & $\begin{array}{l}\text { Latvijas Pašvaldibu savieniba (The Latvian Association of Local and } \\
\text { Regional Governments) }\end{array}$ \\
\hline $\mathrm{RN}-$ & riska novērtējums (Risk Assesment) \\
\hline SIGMA - & $\begin{array}{l}\text { "Atbalsts pārvaldības un vadības uzlabošanā Centrālās un } \\
\text { Austrumeiropas valstīs" (tulkojumā) ir kopīga ESAO }(O E C D) \text { un ES } \\
\text { iniciatīva. Šì iniciatīva atbalsta valsts pārvaldes reformas centienus } 13 \\
\text { valstīs ar pārejas perioda ekonomiku, un to galvenokārt finansē Eiropas } \\
\text { Savienības Phare programma }\end{array}$ \\
\hline SPPI $(I P P F)-$ & $\begin{array}{l}\text { Starptautiskais profesionālās prakses ietvars (International Professional } \\
\text { Practice Framework) }\end{array}$ \\
\hline Standarti - & $\begin{array}{l}\text { Iekšejāa audita profesionālās prakses starptautiskie standarti (International } \\
\text { Standards for the Professional Practice of Internal Auditing) }\end{array}$ \\
\hline VARAM - & $\begin{array}{l}\text { Vides aizsardzības un regionālās attīstības ministrija (The Ministry of } \\
\text { Environmental Protection and Regional Development) }\end{array}$ \\
\hline VK - & Valsts kase (Treasury of Republic of Latvia) \\
\hline VRAA - & $\begin{array}{l}\text { Valsts regionālās attīstības agentūra (The State Regional Development } \\
\text { Agency) }\end{array}$ \\
\hline
\end{tabular}




\section{IZMANTOTĀS LITERATŪRAS UN AVOTU SARAKSTS}

\section{Latvijas Republikas likumi, valdības noteikumi u. c. normatīvie akti, statistikas dati}

1. Centrālās statistikas pārvaldes dati par Latvijas valsts pārvaldes un pašvaldību darbinieku skaitu 2015., 2018. gadā.

2. Eiropas vietējo pašvaldību harta. Eiropas Padome (1985), Nr. 122. Strasbūra, 15.10.1985. Pieejams: https://m.likumi.lv/doc.php?id=39149 [skatîts 22.04.2017.]

3. Eiropas Savienības pilnīgi vai dal̦ēji finansēto programmu un projektu iekšèjā audita metodika (2008). MK instrukcija Nr. 4, spēkā no 24.04.2008.; zaudējis spēku 01.10.2010. Pieejams: http://www.likumi.lv/doc.php?id=174335\&from=off [skatīts 14.05.2012.]

4. Iekšèjā audita likums (2002). Latvijas Republikas likums spēkā no 04.12.2002., zaudējis spēku 16.03.2010. Pieejams: http://www.likumi.lv/doc.php?id=68523 [skatīts 14.05.2012.]

5. Iekšèjā audita likums (2010). Latvijas Republikas likums spēkā no 16.03.2010., zaudējis spēku 11.01.2013. Pieejams: http://www.likumi.lv/doc.php?id=205906\&from=off [skatìts 14.05.2012.]

6. Iekšèjā audita likums (2012). Latvijas Republikas likums spēkā no 11.01.2013. Pieejams: http://likumi.lv/doc.php?id=253680 [skatīts 29.06.2015.]

7. Iekšèjā audita likuma anotācija. MK 24.07.2012. vēstule Nr. 90/TA-1504. Pieejams: http://titania.saeima.lv/LIVS11/SaeimaLIVS11.nsf/0/81316E6CBC37664DC2257A460 0429842?OpenDocument\#b [skatīts 25.02.2017.]

8. Iekšèjā audita metodika (2007). MK instrukcija Nr. 8, spēkā no 27.04.2007., zaudējis spēku 01.10.2010. Pieejams: http://www.likumi.lv/doc.php?id=156401 [skatīts 15.05.2012.]

9. Iekšèjā audita padomes nolikums (1999). MK noteikumi Nr. 346, spēkā ar 09.10.1999., zaudējis spēku 05.06.2003. Pieejams: http://www.likumi.lv/doc.php?id= $16234 \&$ from $=$ off [skatīts 14.05 .2012 .]

10. Iekšèjā audita padomes nolikums (2003). MK noteikumi Nr. 305, spēkā ar 21.06.2003., zaudējis spēku 05.08.2006. Pieejams: http://www.likumi.lv/doc.php?id= 76478\&from $=$ off [skatīts 15.05 .2012 .]

11. Iekšèjā audita padomes nolikums (2006). MK noteikumi Nr. 625, spēkā ar 05.08.2006., zaudējis spēku 24.11.2010. Pieejams: http://www.likumi.lv/doc.php?id= 76478\&from=off [skatīts 15.05.2012.]

12. Iekšejā audita padomes nolikums (2010). MK noteikumi Nr. 1047, spēkā no 24.11.2010. Pieejams: http://www.likumi.lv/doc.php?id=221562 [skatīts 15.05.2012.] 
13. Iekšējā audita veikšanas kārtība (2010). MK noteikumi Nr. 918, spēkā no 07.10.2010., zaudējis spēku 01.06.2013. Pieejams: http://www.likumi.lv/doc. php?id=219073\&from=off [skatīts 08.05.2015.]

14. Iekšējā audita veikšanas un novērtēšanas kārtība (2013). MK noteikumi Nr. 385. Pieejams: http://likumi.lv/doc.php?id=258270 [skatīts 08.05.2015.]

15. Iekšējo auditoru sertifikācijas kārtība (2003). MK noteikumi Nr. 307, zaudējis spēku 01.10.2010. Pieejams: http://www.likumi.lv/doc.php?id=76498 [skatïts 14.05.2012.]

16. Iekšējo auditoru sertifikācijas kārtība (2010). MK noteikumi Nr. 1128, zaudējis spēku 09.05.2013. Pieejams: http://likumi.lv/ta/id/223293-ieksejo-auditoru-sertifikacijaskartiba [skatīts 08.05.2015.]

17. Iekšējo auditoru sertifikācijas kārtība (2013). MK noteikumi Nr. 238, spēkā no 30.04.2013. Pieejams: http://likumi.lv/doc.php?id=256562 [skatīts 08.05.2015.]

18. Kārtība, kādā iestādē tiek veikts iekšējais audits (2003). MK noteikumi Nr. 306, spēkā no 21.06.2003., zaudējis spēku 01.10.2010. Pieejams: http://www.likumi.lv/doc. php?id=76500 [skatīts 14.05.2012.]

19. Latvijas lielo pilsētu asociācijas 02.10.2013. vēstule Nr. 5-1/177 Latvijas Republikas Ministru prezidentam "Par VARAM rīkojumu veikt pārbaudes pašvaldībās".

20. Latvijas Republikas Vides aizsardzības un regionālās ministrijas 26.09.2013. rīkojums Nr. 329 "Par pārbaužu veikšanu pašvaldībās".

21. Likumprojekta "Iekšējā audita likums" anotācijas, 2009., 2012. gads.

22. Noteikumi par iekšējo auditu (1999). MK noteikumi Nr. 342, zaudējis spēku 05.06.2003. Pieejams: http://www.likumi.lv/doc.php?mode=DOC\&id=16230 [skatîts 15.05.2012.]

23. Noteikumi par iekšējās kontroles sistēmas izveidošanas pamatprasībām (2003). MK noteikumi Nr. 466, spēkā no 23.08.2003., zaudējis spēku 01.10.2010. Pieejams: http:// www.likumi.lv/doc.php?id=78263\&from $=$ off [skatìts 15.05.2012.]

24. Noteikumi par iekšējās kontroles sistēmu tiešās pārvaldes iestādēs. MK noteikumi Nr. 326, spēkā no 08.05.2012. Pieejams: http://likumi.lv/doc.php?id=247746 [skatīts 10.06.2015.]

25. Noteikumi par valsts un pašvaldỉbu institūciju amatpersonu un darbinieku darba samaksu un tās noteikšanas kārtību (2013). MK noteikumi Nr. 66 spēkā no 06.02.2013. Pieejams: http://likumi.lv/doc.php?id=254560 [skatìts 05.08.2015.]

26. Par 1985. gada 15. oktobra Eiropas vietējo pašvaldību hartu. Latvijas Republikas likums spēkā no 28.02.1996. Pieejams: http://likumi.lv/doc.php?id=39139 [skatìts 06.06.2015.]

27. Par kopējām valsts pārvaldē auditējamām prioritātēm 2011.-2019. gadā. MK rīkojumi. Pieejams: http://www.fm.gov.lv/lv/sadalas/iekseja_audita_politika/ normativie_akti/ [skatīts 14.03.2019.]

28. Par pasākumu plānu iekšējā audita sistēmas pilnveidošanai. MK 24.02.2010. rīkojums Nr. 114. Pieejams: http://www.likumi.lv/doc.php?id=205819 [skatīts 12.04.2012.]

29. Latvijas Republikas likums "Par pašvaldībām" (1994). Pieejams: http://www.likumi. lv/doc.php?id=57255 [skatīts 23.11.2017.]

30. Latvijas Republikas likums "Par pašvaldību budžetiem" (1995). Pieejams: http://www. likumi.lv/doc.php?mode=DOC\&id=34703 [skatits 12.04.2012.] 
31. Par Valsts pārvaldes politikas attīstības pamatnostādnēm 2014.-2020. gadam. MK rīkojums Nr. 827, Rīgā, 2014. gada 30. decembrī (prot. Nr. 69, 47. §). Pieejams: http:// likumi.lv/doc.php?id=271384 [skatīts 10.08.2015.]

32. Valsts pārvaldes iekārtas likums (2003). Pieejams: http://likumi.lv/doc.php?id= 63545 [skatits 13.05.2015.]

33. Pārskati par iekšējā audita sistēmas darbību valsts pārvaldē 2000.-2016. gadā. Pieejams: http://www.fm.gov.lv/lv/sadalas/iekseja_audita_politika/parskati/ [skatīts 07.05.2015.]

34. Pārskats par iekšèjā audita sistēmas darbību valsts pārvaldē 2001. gadā. Pieejams: http://www.fm.gov.lv/lv/sadalas/iekseja_audita_politika/parskati/2001_gada/ [skatits 25.09.2017.]

35. Pašvaldību pārskati par 2013., 2014., 2015., 2016. gadu. Pieejams: https://www.kase. gov.lv/parskati/pasvaldibu-menesa-un-gada-parskati [skatìts 26.01.2018.]

\section{Autoru darbi}

36. Abdolmohammadi M., D’onza G., Sarens G. (2016) Bechmarking Internal Audit Maturity. CBOK IIARF, 43 p. Available at: www.theiia.org/gotoCBOK [cited 03.08.2016.]

37. Alic M., Rusjan B. (2010) Contribution of the ISO 9001 internal audit to business performance. International Journal of Quality \&Reliability Management, Vol. 27, Iss. 8, pp. 916-937.

38. Anderson U. L. et al. (2010) Effective Sizing of Internal Audit Departments. IIA Research Foundation, Altamonte Springs, Florida, 80 p.

39. Arhipova I., Bāliṇa S. (2003) Statistika ekonomikā. Risinājumi ar SPSS un Microsoft Excel. Datorzinību centrs, 203.-352. lpp.

40. Baggett W. O. (2003) Creating a Culture of Security. Internal Auditor, June, pp. 1-5.

41. Barševska K. (2013) VARAM komentārs par pašvaldību pārbaudèm. Pieejams: http:// www.varam.gov.lv/lat/aktual/preses_relizes/?doc $=17408$ [skatìts 13.08.2015.]

42. Bērzkalns I., Boulton I. (2000) Iekšējās kontroles sistēmas rokasgrāmata. Rīga: Īpašu uzdevumu ministra valsts reformu lietās sekretariāts, 45. lpp.

43. Blažēviča I. (2000) Iekšejjais audits. Grāmatvedība un revīzija. LRZA, febr., 32.-35. lpp.

44. Brink V. Z. (1943) Managerial control through internal auditing. La Salle extension university, $55 \mathrm{p}$.

45. Brink V. Z., Cadmus B. (1950) Internal auditing in industry. Developed under the direction of the Research Committee. 1950, 404 p.

46. Brief R. P., Stern L. N. (1996) New Works in Accounting history. Garnald Publishing, New York and London, 1996, 198 p. Available at: https://books.google.lv/books?id=j kej1jGaqcgC\&pg=PA198\&lpg=PA198\&dq=internal+audit+Dr.Aubrey+Smith+1933\&s ource $=$ bl\&ots $=$ mcGNx_nZz5\&sig=jm6Tc26wEtiRjCGzb5jCm99Tp8A\&hl=lv\&sa=X\& ved=0ahUKEwiciuPL14fOAhUEFSwKHZd5DXQQ6AEIJTAB\#v=onepage\&q=intern al\%20audit\%20Dr.Aubrey\%20Smith\%201933\&f=false [cited 22.07.2016.]

47. Bruna I. (2010) Enterprise Internal Audit and Control. Riga, University of Latvia, $166 \mathrm{p}$. 
48. Bruna I. (2014) Performance of the Public sector's internal audit in Baltic States. The $8^{\text {th }}$ International Days of Statistics and Economics, Prague, September 11-12, pp. 199-209.

49. Burnaby A. P., Hass S. (2011) Internal Auditing in the Americas. Managerial Auditing Journal, Vol. 26, No. 8. Available at: http://www.emeraldinsight.com/search.htm.

50. Chambers A. D., Odar M. (2015) A new vision for internal audit. Managerial Auditing Journal, Vol. 30, No. 1, pp. 34-55. Available at EBSCO data base [cited 03.08.2016.]

51. Chambers A. D. (2014) New guidance on internal audit - an analysis and appraisal of recent developments. Commentary. Managerial Auditing Journal, Vol. 29, No. 2, pp. 196-218.

52. Chapon N. (2012) Questioning the Impact of IA in the Public Sector. Conference on "Public Internal Control systems in the EU Member states", Brussels, 27/28 February Discussion paper on Internal Audit, $8 \mathrm{p}$.

53. Characteristics of an Internal Audit Activity. Dec., 2010, 50 p. IIARF.

54. Chartered Institute of Internal Auditors (2017) Position paper: Internal audit's relationship with external audit. November, $5 \mathrm{p}$.

55. Chen J.-F., Lin W.-F. (2011) Measuring Internal Auditing's Value. The IIA Global Audit Survey. A component of the CBOK Study. IIARF, pp. 1-2.

56. Coetzee P., Fourie H. \& Burnaby P. A. (2015) The growth of the internal audit profession is more than just numbers. Fact or fiction? Evidence from South Africa. Managerial Auditing Journal, Vol. 30, No. 6/7, pp. 514-538. Available at: www.emeraldinsight.com [cited 25.07.2016.]

57. Dābola V. (2013) Iekšejjais audits atbilstoši starptautiskajiem standartiem. IAI Latvijas nodal̦a, semināra materiāli, 28.11.2013.

58. Dābola V. (2016) Izmaiņas standartos. Jauna struktūra jaunam laikmetam. IAI Vēstnesis, 2016, Nr. 9, 5. lpp.

59. Danish Ministry of Finance Internal audit department (2014) Presentation. IAS Conference. Adding value through Internal audit, Brussels, 23.09.2014.

60. Davies M. (2009) Effective working relationships between audit committees and internal audit - the cornerstone of corporate governance in local authorities a Welsh perspective. Available at: https://link.springer.com/article/10.1007/s10997-008-9070-9 [cited 20.02.2019.]

61. Diamond J. (2002) The Role of Internal Audit in Government Financial Management: An International Perspective. International Monetary Fund, 2002, Working Paper, 02/94, 35 p. Doane T. Public Sector Innovation. Internal Auditor, April 2016, 68 p.

62. Dragia M. et al. (2011) Internal Audit and Control Trends in the Public Sector of Transition Countries. Proceeding of the International Scientific Conference, Juraj Dobrila University of Pula, December 1, pp. 62-80. Available at: http://connection. ebscohost.com/c/articles/89602694/internal-audit-control-trends-public-sectortransition-countries [cited 26.02.2019.]

63. Dubis G. S., Jain P., Manchanda A., Thakkar R. (2010) Measuring Internal Audit Efectiveness And Efficiency, Dec., IPPF - Practice Guide. The IIA. 16 p.

64. ECIIA FERMA (2010) Guidance for boards and audit committees. Guidance on the $8^{\text {th }}$ EU Company law directive 2006/43/EC, article 41-46, 21 sept., pp. 7-17.

65. ECIIA (2013) Improving Cooperation Between Internal and External Audit. Position Paper, $11 \mathrm{p}$. 
66. Ekonomikas un finanšu vārdnīca (2003) Rīga: Norden AB, 58.-59. lpp.

67. Ekonomisko terminu vārdnīca uzn̦ēmējdarbībai (1997) Latviešu-angḷu. Ekonomisko reformu institūts. Rīga: Preses nams, $111 \mathrm{lpp}$.

68. Ekonomikas skaidrojošā vārdnīca (2000) Sastādījis autoru kolektīvs R. Grēviṇas vadībā. Rīga: Zinātne, 702 lpp.

69. Ėtikas kodekss. Iekšējo auditoru institūts, 2009. gada janvāris.

70. Faituša I. (2010) Development of Internal audit in Latvia. International Conference "New Socio-Economic Challenges of Development in Europe 2010": Riga, Latvia, October 7-9, 2010. Conference Proceedings. Riga: University of Latvia, 2011, pp. 434-440.

71. Faituša I. (2013) Iekšèjā audita veikšanas metodes. Sabiedrība un Kultūra. Rakstu krājums XV. Liepājas Universitāte. Dabas un sociālo zinātṇu fakultāte, Liepāja, 627.-637. lpp.

72. Faituša I. (2014) Internal Audit System Changes in Local Governments of Latvia "International Conference "New Challenges of Economic and Business Development 2014” (Riga, Latvia, May 8-10): Conference proceedings, pp. 142-148.

73. Faituša I. (2012) Internal Auditing in Local Governments. In International Scientific Conference "New Challenges of Economic and Business Development - 2012". Riga, Latvia, May 10-12, University of Latvia; Conference Proceedings. Riga: University of Latvia, 2012, pp. 171-176.

74. Faituša I. (2012) Opportunities for the Development of Internal Audits Procedures at Local Government Level in Latvia. Journal Economic and Management Research. University of Latvia, Faculty of Economics and Management. Vol. 1, 2012, pp. 45-53.

75. Faitusa I., Grima S., Baldacchino P. J. A. (2016) Comparative Analysis of the EU Public Sector Internal Audit Methodology and Requirements. Proceedings of International Scientific Conference New Challenges of Economic and Business Development - 2016, May 12-14, Riga, University of Latvia, pp. 231-243.

76. Faitusa I. (2015) Public Internal Control in the European Union. Proceedings of the 2015. International Conference Economics Science for Rural Development No. 37 Jelgava, LLU ESAF, 23-24 April 2015, pp. 252-257.

77. Gleizda G. (2013) Jāsaprot, ko tas dara un kur aiziet nauda. Intervija ar IAI valdes priekšsēdētāju un Huawei Technologies IAD viceprezidentu Phil Tarling, 2013. gada 14. marts. Saldo. Dienas Bizness, 1.-2. lpp.

78. Grūba I. (2011) Auditors kustībā. Intervija ar FM Audita un revīzijas departamenta vadìtāju Natu Lasmani. IAI Vēstnesis, Nr. 2, 2.-4. lpp.

79. Grūba I. (2010) Nodošana ārpakalpojumā - plusi un mīnusi. Saldo. Dienas Bizness, Nr. 6, 18.-19. lpp.

80. Guillot C. (2016) Expanding the Foundation. Internal Auditor, February, pp. 17-20. Available at e-resources of University of Latvia Library [cited 21.07.2016.]

81. Gupta P. P. \& Ray M. R. (1992) The Changing Roles of the Internal Auditor. Managerial Auditing Journal, Vol. 7 No. 1, pp. 3-8. Available at: http://datubazes.lanet.lv:3532/ eds/search/basic?sid=8bf55204-5fa $8-4 d 71-9263-6$ d89e36ed39c\%40sessionmgr104\&vi $\mathrm{d}=0$ \&hid=104 [cited 25.07.2016.]

82. Gurkovska V. (2012) Noderīgi: Eiropas Komisijas kopsavilkums par auditoru kontroles sistēmu 27 ES dalïbvalstīs. IAI Vēstnesis, Nr. 4, 5.-6. lpp. 
83. Harrington L., Piper A. (2016) Driving Success in a Changing World. 10 Imperatives for Internal Audit. IIARF, CBOK, 27 p. Available at: www.theiia.org/goto/CBOK [cited 03.08.2016.]

84. Hāznere A. (2006) Risku pārvaldības process, risku identificēšanas un vērtēšanas metodika. Rīga, SEE semināra materiāli, 3.-4. nov.

85. Ievads auditā (2000) ACCA, LU, tulkojusi I. Brūna, E. Kassalis, V. Paupa. 2000, 167 lpp.

86. Ivanova I. Intervija ar IAI pirmās valdes locekḷiem Māri Graudiṇu un Daci Nulli. IAI Vēstnesis Nr. 7, 2014, 5.-10. lpp. Pieejams: http://iai.lv/wp-content/uploads/vestnesis_ nr_7.pdf [skatits 05.07.2015.]

87. Ivanova I., Spruča K. (2015) CBOK aptauja - tendences pasaulē un Baltijas reǵionā. IAI Vēstnesis, Nr. 8, 2015, 5.-12. lpp. Pieejams: http://iai.lv/iai-vestnesis-nr-8oktobris-2015/ [skatìts 17.07.2016.]

88. Jaunzems A. (2009) Risku analize un vadišana. Ventspils: Ventspils Augstskola, $361 \mathrm{lpp}$.

89. Kagerman H., Kinney W. et al. (2008) Internal Audit Hanbook. Springer 2008, Germany, 608 p.

90. Kozlova K., sast. (2016) Atgriešanās Eiropā. Latvijas prezidentu, premjerministru, ministru un diplomātu esejās. ES 1990-2015. Rīga: Zinātne, 8. lpp.

91. Krastiņš O. (1998) Statistika un ekonometrija. Riga: LR CSP.

92. Kubliņš I. (2016) Grāmatvedim nebūtu jārīkojas pretēji profesionālajai un ètiskajai pārliecībai. Intervija ar Elitu Krūmin̦u. Bilance, Nr. 11/12 (383/384), 7.-11. lpp.

93. Kvēle V. (2005) Grāmatvedības jēdzienu skaidrojošā vārdnīca. Rīga: Avots, 253 lpp.

94. Lambrechts A. J., Lourens J. E., Millar P. B., Sparks D. E. (2011) Global Technology Audit Guide (GTAG) 16 Data Analysis Technologies. IIA, Altamonte Springs, Florida, USA, $21 \mathrm{p}$.

95. Lasmane N. (2010) Iekšējais audits valsts pārvaldē - izmaiṇas normatīvajos aktos. Bilance, Nr. 19 (247), 14.-15. lpp.

96. Lenz R., Hahn U. (2015) A synthesis of empirical internal audit effectiveness literature pointing to new research opportunities. Managerial Auditing Journal, Vol. 30, No. 1, pp. 5-363. Available at: http://datubazes.lanet.lv:3532/eds/search/basic?sid=8bf552045fa8-4d71-9263-6d89e36ed39c\%40sessionmgr104\&vid=0\&hid=104 [cited 03.08.2016.]

97. Leung P. et al. (2011) Accountability structures and management relationships of internal audit. An Australian study. Managerial Auditing Journal, Vol. 26, No. 9, pp. 794-816.

98. Liepiņa I. (2009) Uzņēmuma risku atklāšana un novērtēšana ar pašu spēkiem. Bilance, Nr. 18 (22), 28.-31. lpp.

99. MacRae E., Gils D. (2014) Nine Elements Required for Internal Audit Effectiveness in the Public Sector. IIARF, Altamonte Springs, Florida, 48 p.

100. Mālderis G. (2008) Grāmatvedība. Revīzija. Audits. Rīga: SIA “Biznesa augstskola Turība"

101. Mālderis G. (2001) Revīzija un audits. Rìga: SIA "Biznesa augstskola Turība”, 92 lpp.

102. Marks N. (2018) How to Assess the Efectiveness of Internal Audit. Internal Auditor. 3 p. Available at: https://iaonline.theiia.org/how-to-assess-the-effectiveness-ofinternal-audit [cited 25.03.2018.] 
103. Masane-Ose J. (2007) Growing Prestige of Internal auditor Profession in Europe. 10. profesionālā konference "Audits. Revīzija. Nodokḷi. Grāmatvedība”. 88.-89. lpp.

104. Miķelsons S. (2011) Iekšējais audits kā uzṇèmuma treša aizsardzības līnija. Iekšējo auditoru institūts, XII.

105. Model Internal Audit Activity Charter. The Institute of Internal Auditors. Revised: 05/2013.

106. Movsisjana A. (2006) Iekšèjā audita nenovērtētā loma: no diagnozes līdz prognozei. Bilance, Nr. 3, 30.-31. lpp.

107. Nedea C.L. (2015) The Role and Prospects of the Internal Audit in Improving management of Public Institutions. Valahian Journal of Economic Studies, Vol. 6 (20), Issue 3, pp. 7-14.

108. Niekwlands H. (2006) Sustainability and Internal Auditing. IIA Research Foundation, pp. 67-73.

109. Nikolo grupa (2011) Auditoru interviju apkopojums. Nodevums pētījumā "Iekšējās kontroles sistēmas novērtējums un rekomendāciju izstrāde”. Rīga, 20 lpp.

110. Norman C. S. et al. (2010) Internal audit reporting lines, fraud risk decomposition, and assessments of fraud risk. Accounting. Organizations and Society, Vol. 35, pp. 546-557. Available at ScienceDirect.

111. O’Regan D. (2001) Auditing International Entities: a practical guide to risks, objectives and reporting. The IIA Research Foundation, $103 \mathrm{p}$.

112. O’Regan D. (2014) Auditor's Dictionary: Terms, Concepts, Processes, and Regulations. John Wiley \& Sons. Inc, Hoboken, I Jersey, pp. 51-52.

113. Parker G. W. (1995) Auditing of Management Systems. Hampshire, England, 135 p.

114. Paul E. Lindow and Jill D. Race (2002) Beyond Traditional Audit Techniques. Journal of Accountancy, July.

115. Pētersone B. (2010) Iekšējās kontroles sistēmas attīstība valsts pārvaldē. IAI 5. gadskārtējā konference. Rīgā, IX.

116. Pelletier J., Tophoff V. (2016) Inspire, Implement, Assure - How Internal Auditors Can Leverage the International Framework Good Governance in The Public Sector. Oct. 11. Available at: https://www.ifac.org/global-knowledge-gateway/governance/ discussion/inspire-implement-assure-how-internal-auditors-can [cited 25.01.2017.]

117. Pickett K. H. S. (2003) The internal auditing handbook. John Wiley \& Sons Ltd., 786 p.

118. Pilcher R. et al. (2013) The Interface between Internal and External Audit in the Australian Public Sector. Australian Accounting Review, Vol. 23, No. 67, Issue 4, pp. 330-340.

119. Piper A. (2015) Auditing the Public Sector. Managing Expectations, Delivering Results. IIARF, Altamonte Springs, Florida 32701-4201, USA, IIARF, 23 p.

120. Ramamoorti S. (2003) Chapter 1: Internal Auditing: History, Evolution, and Prospects. The IIA Research Foundation, Altamonte Springs, Florida, pp. 2-14.

121. Ramamoorti S., Siegfried A. N. (2016) Promoting and Supporting Effective Organizational Governance. Internal Audit's Role. CBOK, IIARF, 39 p.

122. Ray E. (2009) Adding Value: How Modern Internal Auditing Assists Organizations in Achieving Strategic Objectives. IIARF, pp. 4-5.

123. Reding Kurt F. et al. (2007) Internal Auditing Assurance \& Consulting Services. IIA Research Foundation, Altamonte Springs, 45 p.

124. Rouldigins V. Starptautiskā biznesa skaidrojošā vārdnīca. Rīga: Jumava, 2005, 36. lpp. 
125. Rose J. (2013) Brieduma model̦u izvēle, izmantošana un izveide: rīks izmantošanai pārliecības gūšanas, konsultāciju pakalpojumos. IAI tulkojums

126. Sarens G. et al. (2011) Are internal auditing practices related to the age of the internal audit function? Managerial Auditing Journal, Vol. 26, No. 1, 2011, pp. 51-64.

127. Sarens G., Lamboglia R. (2014) The (mis) fit between the profile of internal auditors and internal audit activities. Accounting and business Research, Vol. 44, No. 1, pp. 41-62.

128. Sawyer L. B., Dittenhofer M. A. (1996) Sawyer's internal auditing: the practice of modern internal auditing. Altamonte Springs, Florida. Institute of Internal Auditors, $1499 \mathrm{p}$.

129. Sawyer L. B. (1995) An Internal Audit Philosophy. Internal Auditor. Aug., Vol. 52, Issue 4, p. 10. Available at e-resources of University of Latvia http://datubazes.lanet.lv: [cited 23.02.2019.]

130. SIGMA (2005). Ekspertu palīdzība valsts iekšējā audita sistēmai Latvijā. SIGMA ekspertu sagatavotais detalizētais ziņojums; aprīlis, 88 lpp.

131. Sīle L. (2012) IAI un Finanšu ministrijas isstenotais kopprojekts "Risku modelis valsts pārvaldei”. IAI Vēstnesis, Nr. 4, 7. lpp.

132. Strazdiņš P. (2008) Pieci izaicinoši aspekti iekšejāa audita profesijā. Bilance, Nr. 13 (193), 6.-8. lpp.

133. Supplemental guidance (2012) The Role of Auditing in Public Sector Governance, $2^{\text {nd }}$ edition. Altamote Springs FL, The IIA, January, pp. 6-8.

134. Šulca R. (2010) Latvijas pašvaldību iekšèjā audita sistēmas attīstības iespējas. Pētījuma kopsavilkums. Jelgava, 2010, 131 lpp.

135. Soh D. S. B. and Martinov-Bennie N. (2011) The internal audit function. Perceptions of internal audit roles, effectiveness and evaluation. Managerial Auditing Journal, Vol. 27, No. 7, pp. 605-622.

136. State Regional Development Agency (2011) Development of Regions in Latvia. Riga, $171 \mathrm{p}$.

137. Swinkels W. H. A. (2012) Exploration of a theory of internal audit. Akademisch proefschrift. Universiteit van Amsterdam, $241 \mathrm{p}$.

138. Taxation trends in the European Union (2014 edition). Taxation and Customs Union, EU, 2014, $308 \mathrm{p}$.

139. Taylor D. H., Glezen G. W. (1997) Auditing An Assertion Approach. $7^{\text {th }}$ ed., New York, pp. $5-7,712-713$.

140. Taylor D. H., Glezen G. W. (1994) Auditing integrated concepts and procedures. Canada, 1994, 1023 p.

141. The audit committee and the CAE (2013) Sustainable a strategic partnership. The IIARF White paper, IIARF, 2013. Altamonte Spring, Florida, e/SBN-13: 978-0-89413730-3, pp. 5-18.

142. The IIA Global Internal Audit Survey (2010) Characteristics of an Internal Audit Activity. A Component of the CBOK Study, IIARF, Dec., 2010, Altamonte Springs, Florida, $60 \mathrm{p}$.

143. The IIA (2014) Vērtības radīšana sadarbojoties: aicinājums rīkoties. Globālais ziņojums, jūlijs, 15. lpp.

144. The Institute of Internal Auditors (2001) Independence and Objectivity: A Framework for Internal Auditors. Altamonte Springs, FL, $61 \mathrm{p}$. 
145. Uzulāns J. (2004) Projektu vadība. Rīga: Jumava, Biroja sērija, 2004, 82.-92., 117.-120., 244. lpp.

146. Uzulāns J. (2010) Risku vadība projektu kontekstā. Rīga: Drukātava, 2.-27., 42.-51., 136. lpp.

147. Vaitkevicius J. (2014) Public sector internal audit in the Republic of Lithuania. Meeting of the INTOSAI Internal Control Standards Subcommittee. Vilnius, 27-28 May.

148. Valsts reǵionālās attīstības aǵentūra (2011) Reǵionu attīstība Latvijā 2010, Rīga, 171 lpp.

149. Vanags E. (2007) Valsts pārvaldes reformas ārvalstīs un Latvijā. Rīga: Latvijas Statistikas institūts, 35.-36. lpp.

150. Vērdiṇa G. (2012) Iekšéjās kontroles sistēmas pilnveidošanas iespējas studiju programmas ìstenošanas procesos. Promocijas darbs vadībzinātnes doktora zinātniskā grāda iegūšanai izglīiības vadības apakšnozarē. Rīga: LU PPMF, 252 lpp.

151. Wade K. W. (2001) Iekšējā audita apjoms. Grāmatvedība un revĩzija. 2001/5, 11.-13. lpp.

152. William C. B., Raymond N. J., Walter G. K. (2001) Modern Auditing. $7^{\text {th }}$ edition, John Wiley \& Sons, Inc., 1044 p.

153. Zaman M., Sarens G. (2013) Informal interactions between audit committees and internal audit functions. Explorary evidence and directions for future research. Managerial Auditing Journal, Vol. 28, No. 6, pp. 495-515.

154. Zammit S., Baldacchino P. (2012) Overcoming Barriers between the Internal and External Audit Functions in Malta. International Journal of Government Auditing, April, pp. 14-18.

155. Теория статистики (2000) Учебник. Под ред. проф. Г. Л. Громыко. Серия «Высшее образование». Москва, ИНФРА-М, 414 с.

\section{Interneta resursi}

156. About The Committee of Sponsoring Organizations of the Treadway Commission COSO. Available at http://info.knowledgeleader.com/bid/161685/what-are-the-fivecomponents-of-the-coso-framework [cited 23.02.2018.]

157. Akadēmiskā terminu datubāze AkadTerm. Audita un revīzijas definīcijas. Pieejams: http://termini.lza.lv/term.php?term=rev\%C4\%ABzija\&list=rev\%C4\%ABzija\&lang= LV [skatìts 11.02.2016.]

158. Astrals Internal Audit Methodology, (India). Available at http://www.advanceecom solutions.com/newsletter/internal_audit_services_at_astral.html [cited 05.08.2012.]

159. Audit Committee Institute. KPMG. Available at www.kpmg.co.uk/aci [cited: 02.02.2018.]

160. Compendium of the Public Internal Control Systems in the EU Member States 2012. Luxembourg: Publications Office of the European Union, 2011. Available at http:// ec.europa.eu/budget/library/biblio/publications/2011/compendium_27_countries_ en.pdf [cited 09.07.2015.]

161. Compendium of the Public Internal Control Systems in the EU Member States. Second edition, Luxembourg: Publications Office of the European Union, 2014, ISBN: 978-922-79-37868-3. Available at http://ec.europa.eu/budget/pic/compendium/ index_en.cfm [cited 09.07.2015.] 
162. Dābola V. Izmaiṇas standartos. Pieejams: http://iai.lv/izmainas-standartos-jaunastruktura-jaunam-laikmetam / [skatīts 30.06.2017.]

163. Davide McCabe. Lawrence B. Sawyer The Father of Modern Internal Auditing, 2004. Available at http://www.thesawyerlegacy.com/ [cited 12.05.2015.]

164. Eiropas valstu 2015. gada pašvaldību ien̦ēmumu īpatsvars vispārējās valdības ieṇēmumos, \%. Pieejams: http://www.fm.gov.lv/lv/sadalas/pasvaldibu_finansu_uzraudziba/ latvijas_pasvaldibu_budzeta_raditaju_salidzinajums_ar_eiropas_valstim/2015_ gads/ [skatīts 20.10.2017.]

165. Ëtikas kodekss. Pieejams: https://na.theiia.org/standards-guidance/mandatoryguidance/Pages/Code-of-Ethics.aspx [cited 26.01.2018.]

166. Iekšejāa audita darbības novērtēšana. Pieejams: http://www.fm.gov.lv/lv/sadalas/ iekseja_audita_politika/iekseja_audita_darbibas_novertesana/ [skatīts 01.07.2016.]

167. Iekšējā audita definīcija. Iekšējo auditoru institūts, 2008. Pieejams: http://iai.lv/lv/ standarti [skatīts 20.01.2012.]

168. Iekšèjā auditoru institūta skaidrojumi IA definīcijai. Pieejams: http://iai.lv/ieksejamauditoram/iekseja-audita-definīcija [skatīts 26.08.2015.]

169. IAI oficiālie auditori par iekšêjā audita lomu kompleksajā uzṇēmuma riska vadībā. Pieejams: http://www.iai.lv/files/Biedriem/standarti/2010/ippf_pp_role_of_ia_in_erm_ lv_01.09.2010.pdf [skatīts 23.08.2012.]

170. Iekšējā audita profesionālās prakses starptautiskie standarti (Standarti), IAI. Pieejams: https://global.theiia.org/translations/PublicDocuments/IPPF-Standards-2017Latvian.pdf [skatīts 30.06.2017.]

171. Iekšejo auditoru institūta misija, auditor. Pieejams: https://na.theiia.org/about-us/ Pages/About-The-Institute-of-Internal-Auditors.aspx [skatits 08.05.2015.]

172. Internal audit. Interactive Terminology for Europe. Available at http://iate.europa.eu/ SearchByQuery.do [cited 25.01.2017.]

173. Internal audit definition. Glossary IFAC. Available at http://www.ifac.org/system/ files/downloads/a005-2010-iaasb-handbook-handbook-glossary.pdf [cited 24.01.2017.]

174. Termina "Internal audit" tulkojums. Letonika: Angḷu-latviešu vārdnīca. Pieejams: http://www.letonika.lv/groups/default.aspx?cid=269404\&r=10331062\&lid=269404\&g= $2 \& \mathrm{q}=$ internal\%20audit $\& \mathrm{~h}=4708$ [pēdējo reizi skatīts 25.01.2017.]

175. Internal Audit Competency Framework. Available at https://global.theiia.org/about/ about-internal-auditing/Pages/Competency-Framework.aspx [skatīts 29.06.2017.]

176. Internal audit methodology, BDO Belgium. Available at http://www.bdo.be/ internal\%20audit [cited 05.08.2012.]

177. International Professional Practices Framework, 2009. Available at http://www.svir. ch/xml_1/internet/en/application/d271/d272/f273.cfm [cited 06.08.2012.]

178. International standards for the professional practice of internal auditing. Available at http://iai.lv/lv/standarti [cited 26.01.2012.]

179. Klismeta G. Saruna ar VARAM ministru K. Gerhardu "Vai nu "A" vai "B”". Logs, 2017, Nr. 1 (259). Pieejams: http://www.lps.lv/lv/zurnals-logs-infolapa/zurnals-logs/ [skatìts 22.04.2017.]

180. Latvijas Pašvaldību audita vienību ROKASGRĀMATA. Pieejams: http://varam.gov. $\mathrm{lv} / \mathrm{lat} / \mathrm{publ} / \mathrm{met} / \mathrm{pasv} /$ ?doc=13181 [skatīts 28.01.2017.] 
181. Latvijas pašvaldību budžeta rādītāju salīdzinājums ar Eiropas valstīm. Pieejams: http:// www.fm.gov.lv/lv/sadalas/pasvaldibu_finansu_uzraudziba/latvijas_pasvaldibu_ budzeta_raditaju_salidzinajums_ar_eiropas_valstim/2016_gads/ [skatīts 31.01.2018.]

182. Latvijas Republikas Vides aizsardzības un regionālās ministrijas komentārs par pašvaldību pārbaudēm 03.10.2013. Pieejams: http://www.varam.gov.lv/lat/aktual/ preses_relizes/ [skatīts 13.10.2017.]

183. Liepiņš V. Vēlēšanu sistēmas. Priekšrocības un trūkumi. Pieejams: http://www. lvportals.lv/visi/likumi-prakse/186897-velesanu-sistemas-prieksrocibas-un-trukumi/ [skatìts 28.01.2017.]

184. Linnas R. Legal Regulation of Internal audit in Estonia. Conference on Internal Audit and Corporate Governance, April 18-19, 2012. Available at http://www.iacmaster. it/iacgconference2012/wp-content/uploads/2012/04/Raivo-Linnas.pdf [cited 12.03. 2016.]

185. Latvijas Republikas 2015. gada pārskats par valsts budžeta izpildi un par pašvaldību budžetiem. LR VK, Rīga, 2016. gada 15. septembris. Pieejams: http://www.lrvk.gov. lv/uploads/reviziju-zinojumi/2015/2.4.1-34_2015/3.3.-revizijas-zinojums-sgp-2015_ publicesanai.pdf [skatīts 27.01.2017.]

186. Nodokḷu ien̦ēmumu sadalījums pa budžetiem procentos no kopējiem ien̦ēmumiem 2017. gadā. Pieejams: http://www.fm.gov.lv/lv/sadalas/valsts_budzets/nodoklu_ienemumu_sadalijums_pa_budzetiem/ [skatīts 26.02.2017.]

187. Novadu veidošanas rokasgrāmata. Reǵionālās attīstības un pašvaldību lietu ministrija, 01.08.2009. Pieejams: http://www.varam.gov.lv/lat/publ/met/pasv/?doc=13181 [skatits 22.04.2017.]

188. Par Ditenhoffer M. A. Pieejams: http://www.legacy.com/obituaries/washingtonpost/ obituary.aspx?pid=178032786 [cited 03.08.2016.]

189. Par Sawyer L. B. The Sawyer Legacy. Available at http://www.thesawyerlegacy.com/ [cited 22.07.2016.]

190. VARAM (2017) par informatīvo ziņojumu "Par valsts administratīvi teritoriālo iedalījumu un valsts pārvaldes institūciju sadarbības teritoriju izveidi". Pieejams: http://www.lps.lv/uploads/docs_module/Par\%20informat\%C4\%ABvo\%20 zi\%C5\%86ojumu\%20\%E2\%80\%9CPar\%20valsts\%20administrat\%C4\%ABvi\%20 teritori\%C4\%81lo\%20iedal\%C4\%ABjumu\%20un\%20valsts\%20p\%C4\%81rvaldes\%20 instit\%C5\%ABciju\%20sadarb\%C4\%ABbas\%20teritoriju\%20izveidi\%E2\%80\%9D.pdf [skatits 17.04.2017.]

191. Par Latvijas Republikas 2013. gada pārskatu par valsts budžeta izpildi un par pašvaldību budžetiem. LR VK Revizijas ziņojums, 15.09.2014. Pieejams: http://www. lrvk.gov.lv/uploads/reviziju-zinojumi/2013/5.1-2-32-2_2013/pasvaldibu-zinojumspubliskosanai-02-10-2014.pdf [skatìts 06.06.2015.]

192. Pasaules iekšējā audita publikāciju un auditoru vēsturiskais katalogs. Pieejams: http:// catalog.hathitrust.org/Record/007903615 [skatīts 19.08.2015.]

193. Pašvaldību administratīvi teritoriālās vienības uz 06.01.2010. Pieejams: http://www. lps.lv/Pasvaldibas/ [skatīts 18.03.2010.]

194. Pašvaldību finanšu rādītāju analīze. Latvijas Republikas Finanšu ministrijas Pašvaldību finansiālās darbības uzraudzības un finansēšanas departaments. Pieejams: http:// fm.gov.lv/?lat/pasvaldibam/pasvaldibu_finansu_raditaju_analize [skatits 03.01.2012.] 
195. Revīzijas ziņojums par Latvijas Republikas 2014. gada pārskatu. Par valsts budžeta izpildi un par pašvaldỉbu budžetiem. Pieejams: http://www.lrvk.gov.lv/uploads// reviziju-zinojumi/2014/2.4-1-39_2014/sgp_zinojums_01102015.pdf skatīts 18.08.2016.]

196. Riski valsts pārvaldes iestādēs. Informatīvs materiāls iekšējiem uditorium. IAI, 04.01.2012. Pieejams: http://iai.lv/wp-content/uploads/vadlinijas_risku_modelis_ valsts_prvaldeil.pdf [skatìts 28.08.2015.]

197. Role of Audit Committees for IA in the public sector. Discussion paper No. 4 PIC an EU Approach, ref. 2014-4. Available at http://ec.europa.eu/budget/pic/lib/docs/ pic_paper4_en.pdf [cited 24.02.2018.]

198. Skujiņa V. Vai termini audits un revizzija un arī auditors un revidents ir sinonīmi? Terminologijas Jaunumi. Pieejams: http://termini.lza.lv/article.php?id=70 [skatīts 14.03.2010.]

199. Standards \& Guidance. Available at https://global.theiia.org/standards-guidance/ Pages/Standards-and-Guidance-IPPF.aspx [cited 29.06.2017.]

200. Sudraba I. Par diskusiju LU doktorantūras skolā. E-pasts, 2012. Ar viedokli par iekšējā audita ieviešanu Latvijas pašvaldībās.

201. Termini metodika un nolikums (2000) Ekonomikas skaidrojošā vārdnīca. Rīga: Zinātne. Pieejams: http://termini.lza.lv/term.php?term=metodika\&lang=LV un http:// termini.lza.lv/term.php?term=nolikums\&lang=LV [skatìts 12.03.2017.]

202. Terminu skaidrojums par tiešo valsts pārvaldi. Pieejams: http://tpi.mk.gov.lv/Terms. html [skatīts 13.05.2015.]

203. The International Professional Practices Framework (IPPF). Available at https://na.theiia. org/standards-guidance/Pages/Standards-and-Guidance-IPPF.aspx [cited 26.01.2018.]

204. LR VK revīzijas secinājumi apliecina nepieciešamību veidot sadarbības teritorijas Latvijā. 24.03.2017. Pieejams: http://www.varam.gov.lv/lat/aktual/preses_relizes/?doc= 23982 [skatīts 17.04.2017.]

205. Valsts tiešās pārvaldes iestāžu datubāze. Pieejams: http://tpi.mk.gov.lv/ui/default. aspx?MenuID=4 [skatīts 13.05.2015.]

206. Zaman A. New IPPF 2015 (Summary). 09.08.2015. Available at https://www.linkedin. com/pulse/new-ippf-2015-summary-cia-cisa-cpa-cfe-ccsa-crma-cga [cited 29.06.2017.]

\section{Citi avoti}

207. Finanšu ministrija (2011) Iekšējā audita veikšanas vadlīnijas. Nepublicētā informācija.

208. Izraksts no LZA TK 13.09.2016. sēdes protokola Nr. 6/1130.

209. Latvijas Republikas Finanšu ministrija, PricewaterhouseCoopers (2006) Latvijas Republikas Izpildes novērtējuma auditi.

210. Par informācijas sniegšanu. LR VK 12.11.2014. vēstule Nr. 11.3.5.4.2/156 Ivitai Faitušai.

211. VARAM IAS sniegtā nepublicētā informācija par pašvaldību pārbaužu rezultātiem. 


\section{PIELIKUMI}

1. pielikums

\section{Normatīvie akti iekšējā audita jomā no 1999. gada līdz 2013. gadam}

\begin{tabular}{|c|c|c|c|}
\hline Datums & Normatīvā akta veids un nosaukums & Darbïbas laiks & Periods \\
\hline 05.10.1999. & $\begin{array}{l}\text { MK noteikumi Nr. } 342 \text { "Noteikumi par iekšējo } \\
\text { auditu" }\end{array}$ & 09.10.1999.-05.06.2003. & \multirow{2}{*}{$\begin{array}{l}\text { lekšējā audita } \\
\text { ieviešana } \\
\text { Latvijas valsts } \\
\text { pārvaldē }\end{array}$} \\
\hline 05.10.1999. & $\begin{array}{l}\text { MK noteikumi Nr. } 346 \text { "lekšējā audita } \\
\text { padomes nolikums" }\end{array}$ & 09.10.1999.-05.06.2003. & \\
\hline 31.10.2002. & lekšējā audita likums & 04.12.2002.-16.03.2010. & \multirow{8}{*}{$\begin{array}{l}\text { Pārejas } \\
\text { periods - } \\
\text { statusu } \\
\text { maiṇa - } \\
\text { ES prasību } \\
\text { iekḷaušana IA } \\
\text { normatīvajos } \\
\text { aktos }\end{array}$} \\
\hline 10.06.2003. & $\begin{array}{l}\text { MK noteikumi Nr. } 306 \text { "Kārtība, kādā iestādē } \\
\text { tiek veikts iekšējais audits" }\end{array}$ & 21.06.2003.-01.10.2010. & \\
\hline 10.06.2003. & $\begin{array}{l}\text { MK noteikumi Nr. } 305 \text { "lekšējā audita } \\
\text { padomes nolikums" }\end{array}$ & 21.06.2003.- 05.08.2006. & \\
\hline 10.06.2003. & $\begin{array}{l}\text { MK noteikumi Nr. } 307 \text { "lekšējo auditoru } \\
\text { sertifikācijas kārtība" }\end{array}$ & 21.06.2003.- 01.10.2010. & \\
\hline 19.08.2003. & $\begin{array}{l}\text { MK noteikumi Nr. } 466 \text { "Noteikumi par } \\
\text { iekšējās kontroles sistēmas izveidošanas } \\
\text { pamatprasībām” }\end{array}$ & 23.08.2003.-01.10.2010. & \\
\hline 16.01.2007. & $\begin{array}{l}\text { MK noteikumi Nr. } 55 \text { "IAS darba salīdzinošo } \\
\text { pārbaužu veikšanas kārtība” }\end{array}$ & 19.01.2007.- 18.08.2010. & \\
\hline 24.04.2007. & MK instrukcija Nr. 8 "lekšējā audita metodika" & 27.04.2007.-01.10.2010. & \\
\hline 21.04 .2008 & $\begin{array}{l}\text { MK instrukcija Nr. } 4 \text { "Eiropas Savienības } \\
\text { pilnīgi vai dalēji finansēto programmu un } \\
\text { projektu iekšejjā audita metodika" }\end{array}$ & 24.04.2008.- 01.10.2010. & \\
\hline 11.02.2010. & lekšējā audita likums & 16.03.2010.-11.01.2013. & \multirow{4}{*}{$\begin{array}{l}\text { Starptautisko } \\
\text { standartu } \\
\text { prasību } \\
\text { iekḷaušana } \\
\text { normativajos } \\
\text { aktos }\end{array}$} \\
\hline 10.08.2010. & $\begin{array}{l}\text { MK noteikumi Nr. } 760 \text { "IAS darba salīdzinošo } \\
\text { pārbaužu veikšanas kārtība" }\end{array}$ & 19.08.2010.-01.06.2013. & \\
\hline 28.09.2010. & $\begin{array}{l}\text { MK noteikumi Nr. } 918 \text { "lekšējā audita } \\
\text { veikšanas kārtība" }\end{array}$ & 07.10.2010.-01.06.2013. & \\
\hline 14.12.2010. & $\begin{array}{l}\text { MK noteikumi Nr. } 1128 \text { “lekšējo auditoru } \\
\text { sertifikācijas kārtība” }\end{array}$ & 29.12.2010.- 09.05.2013. & \\
\hline 13.12.2012. & lekšējā audita likums & Kopš 11.01.2013. & \multirow{3}{*}{$\begin{array}{l}\text { lekšējā audita } \\
\text { sistēmas, } \\
\text { tiesiskā } \\
\text { regulējuma } \\
\text { pilnveidošana }\end{array}$} \\
\hline 30.04.2013. & $\begin{array}{l}\text { MK noteikumi Nr. } 238 \text { "lekšējo auditoru } \\
\text { sertifikācijas kārtība" }\end{array}$ & Kopš 08.05.2013. & \\
\hline 09.07.2013. & $\begin{array}{l}\text { MK noteikumi Nr. } 385 \text { "lekšējā audita } \\
\text { veikšanas un novērtēšanas kārtība" }\end{array}$ & Kopš 17.07.2013. & \\
\hline
\end{tabular}

Avots: autores veidota tabula, pamatojoties uz normatīvajiem aktiem. 


\section{Atsevišḳas kopējās valsts pārvaldē auditējamās prioritātes 2013.-2018. gadā}

\begin{tabular}{|c|c|}
\hline Gads, MK rīkojums & Kopējās valsts pārvaldē auditējamās prioritātes \\
\hline $\begin{array}{l}2013 . \\
\text { MK 07.12.2012. } \\
\text { rīkojums Nr. } 573 \\
\text { "Par kopējām } \\
\text { valsts pārvaldē } \\
\text { auditējamām } \\
\text { prioritātēm } \\
\text { 2013. gadam" }\end{array}$ & $\begin{array}{l}\text { FM un VARAM IAS 2013. gadā veikt pašvaldību finanšu pārskatu sagatavošanas } \\
\text { nenodoklu ieñēmumu un ilgtermiṇa ieguldījumu uzskaites jomā uzraudzības un } \\
\text { IKS darbības auditu: } \\
\text { * } \quad \text { kā tiek veikta pašvaldību finanšu pārskatu sagatavošanas uzraudzība, novērtēt } \\
\text { IKS darbību, identificējot LR VK revīziju ziṇojumos sniegto nepilnību cēloṇus; } \\
\text { * novērtēt pašvaldībām piederošo kapitālsabiedrību darbības pārraudzības } \\
\text { pietiekamību. } \\
\text { Ministriju un iestāžu IAS 2013. gadā katra IA ietvaros atbilstoši IA jomu } \\
\text { reglamentējošajos normatīvajos aktos noteiktajai metodikai novērtēt: } \\
\text { * interešu konflikta iespējamību; } \\
\text { * interešu konflikta mazināšanai izveidotās kontroles sistēmas atbilstību } \\
\text { noteiktajam mērksim un pietiekamību; } \\
\text { * interešu konflikta mazināšanai izveidotās kontroles sistēmas darbību. }\end{array}$ \\
\hline $\begin{array}{l}2014 . \\
\text { MK 04.12.2013. } \\
\text { rīkojums Nr. } 591 \\
\text { "Par kopējām } \\
\text { valsts pārvaldē } \\
\text { auditējamām } \\
\text { prioritātēm } \\
\text { 2014. gadam" }\end{array}$ & $\begin{array}{l}\text { Novērtēt ministrijās un iestādēs izveidotās likumu un MK noteikumu izstrādes un } \\
\text { virzības IKS, tajā skaitā novērtējot: } \\
\text { * } \quad \text { likumu un MK noteikumu izstrādes savlaicīgumu un atbilstību prasībām } \\
\text { (termiṇi, kārtība); } \\
\text { * } \quad \text { sabiedrības līdzdalības nodrošināšanu likumu un MK noteikumu izstrādē } \\
\text { atbilstoši šo jomu reglamentējošo normatīvo aktu prasībām. Novērtēt arī, vai } \\
\text { ministriju un iestāžu ētikas kodeksos ir iekḷauti valsts amatpersonu uzvedības } \\
\text { noteikumi komunikācijā ar lobētājiem; } \\
\text { * likumu un MK noteikumu izstrādes ekonomisko efektivitāti (laiks, izmaksas, } \\
\text { izveidotās kontroles, lai novērstu ārējo normatīvo aktu dublēšanos, un to } \\
\text { darbība); } \\
\text { *ai ministrijām un iestādēm izlases veidā atbilstoši riska novērtējumam } \\
\text { turpināt vienlaikus veikt līdzīgu procesu auditus attiecīgā resora iestādēs. }\end{array}$ \\
\hline $\begin{array}{l}2015 . \\
\text { MK 28.10.2014. } \\
\text { rīkojums Nr. } 615 \\
\text { "Par kopējām } \\
\text { valsts pārvaldē } \\
\text { auditējamām } \\
\text { prioritātēm } \\
\text { 2015. gadam" }\end{array}$ & $\begin{array}{l}\text { 1. Veikt IT vadības sistēmas IA, novērtējot informācijas un komunikācijas } \\
\text { tehnoloǵiju pārvaldības organizēšanu, nepieciešamo resursu plānošanu, } \\
\text { uzskaiti, sagādi, ieviešanu, izmantošanu, uzturēšanu, koplietošanu, } \\
\text { optimizēšanu un valsts informācijas sistēmu drošības pasākumu izveidi. } \\
\text { 2. FM sadarbībā ar VARAM izstrādāt un līdz 2014. gada 30. decembrim } \\
\text { elektroniski nosūtīt ministriju un iestāžu IAS IA veikšanas vadlīnijas. } \\
\text { 3. Ministrijas un iestādes IAS pēc IA slēgšanas, bet ne vēlāk kā līdz 2016. gada } \\
\text { 15. janvārim iesniegt FM IA ziṇojumu, ieteikumu ieviešanas grafiku un } \\
\text { pārskatu. } \\
\text { 4. Ministrijām un iestādēm izlases veidā atbilstoši riska novērtējumam turpināt } \\
\text { vienlaikus veikt līdzīgu procesu auditus attiecīgā resora iestādēs. } \\
\text { 5. FM apkopot IA rezultātus un līdz 2016. gada 15. martam iesniegt VARAM. }\end{array}$ \\
\hline $\begin{array}{l}2016 . \\
\text { MK 01.10.2015. } \\
\text { rīkojums Nr. } 609 \\
\text { "Par kopējām } \\
\text { valsts pārvaldē } \\
\text { auditējamām } \\
\text { prioritātēm } 2016 . \\
\text { gadam" }\end{array}$ & $\begin{array}{l}\text { 1. Veikt attiecīgi ministrijā un iestādē izveidotās IT vadības sistēmas iekšējo } \\
\text { auditu, novērtējot iekšējās IKS informācijas un komunikāciju tehnoloǵiju } \\
\text { projektu vadībā (turpmāk - informācijas un komunikāciju tehnoloǵiju audits). } \\
\text { 2. FM sadarbībā ar VARAM izstrādāt un līdz 2016. gada 19. februārim elektroniski } \\
\text { nosūtīt ministriju un iestāžu iekšējā IAS informācijas un komunikāciju } \\
\text { tehnoloǵiju audita vadlīnijas. } \\
\text { 3. Ministrijas un iestādes IAS struktūrvienībai pēc informācijas un komunikāciju } \\
\text { tehnoloǵiju audita slēgšanas, bet ne vēlāk kā līdz 2017. gada 15. janvārim } \\
\text { iesniegt FM šī audita ziñojumu, ieteikumu ieviešanas grafiku un pārskatu, kas } \\
\text { sagatavots atbilstoši vadlīnijās noteiktajai struktūrai. }\end{array}$ \\
\hline
\end{tabular}


2. pielikuma turpinājums

\begin{tabular}{|c|c|}
\hline Gads, MK rīkojums & Kopējās valsts pārvaldē auditējamās prioritātes \\
\hline & $\begin{array}{l}\text { 4. Ministriju un iestāžu IAS izlases veidā atbilstoši riska novērtējumam turpināt } \\
\text { vienlaikus veikt līdzīgu procesu IA attiecīgā resora iestādēs. } \\
\text { 5. FM apkopot informācijas un komunikāciju tehnoloǵiju auditu rezultātus un } \\
\text { līdz 2017. gada 15. martam iesniegt VARAM. }\end{array}$ \\
\hline $\begin{array}{l}2017 . \\
\text { MK 26.10.2016. } \\
\text { rīkojums Nr. } 625 \\
\text { "Par kopējām } \\
\text { valsts pārvaldē } \\
\text { auditējamām } \\
\text { prioritātēm } 2017 . \\
\text { gadam" }\end{array}$ & $\begin{array}{l}\text { 1. Veikt valsts pārvaldes pakalpojumu IA, novērtējot: } \\
\text { 1.1. valsts pārvaldes pakalpojumu kvalitāti; } \\
\text { 1.2. valsts pārvaldes pakalpojumu organizāciju un pieejamību } \\
\text { privātpersonām (vienas pieturas aǵentūras principa ieviešana, } \\
\text { e-pakalpojumu attīstība); } \\
\text { 1.3. administratīvo slogu un tā mazināšanas iespējas valsts pārvaldes } \\
\text { pakalpojumu sniegšanas nodrošināšanā. } \\
\text { 2. FM sadarbībā ar VARAM, VRAA un Valsts kanceleju izstrādāt IA vadlīnijas. } \\
\text { 3. Ministriju un iestāžu IAS pēc IA slēgšanas, bet ne vēlāk kā līdz 2018. gada } \\
\text { 1. martam iesniegt FM IA ziņojumu, ieteikumu ieviešanas grafiku un pārskatu, } \\
\text { kas sagatavots atbilstoši vadlīnijās noteiktajai struktūrai. } \\
\text { 4. Ministriju un iestāžu IAS izlases veidā atbilstoši riska novērējumam turpināt } \\
\text { vienlaikus veikt līdzīgu procesu IA attiecīgā resora iestādēs. } \\
\text { 5. Politiku, kuras plānošana, īstenošana un uzraudzība mijiedarbojas ar citiem } \\
\text { resoriem, auditēšana, nodrošinot savstarpēju sadarbību un pēc iespējas } \\
\text { veidojot starpresoru IA komandas. } \\
\text { 6. FM apkopot IA rezultātus un līdz 2018. gada 1. jūnijam iesniegt tos VARAM un } \\
\text { Valsts kancelejā. }\end{array}$ \\
\hline $\begin{array}{l}2018 . \\
\text { MK 25.10.2017. } \\
\text { rīkojums Nr. } 605 \\
\text { "Par kopējām } \\
\text { valsts pārvaldē } \\
\text { auditējamām } \\
\text { prioritātēm } 2018 . \\
\text { gadam" }\end{array}$ & $\begin{array}{l}\text { 1. Ministriju un iestāžu IAS atbilstoši normatīvajos aktos noteiktajai kārtībai un } \\
\text { metodikai, kā arī vadlīnijām veikt valsts pārvaldes uzdevumu deleǧēšanas } \\
\text { iekšējo auditu. } \\
\text { 2. Ministriju un iestāžu IAS plānoto IA ietvaros: } \\
\text { 1) novērtēt, vai ieviestie IKS elementi sekmē procesu efektīvāku norisi un } \\
\text { veicina orientāciju uz sasniedzamo rezultātu; } \\
\text { 2) izlases veidā atbilstoši riska novērtējumam turpināt vienlaikus veikt līdzīgu } \\
\text { procesu IA attiecīgā resora iestādēs; } \\
\text { 3) nodrošināt savstarpēju sadarbību un pēc iespējas veidot starpresoru IA } \\
\text { komandas, auditējot tādu politiku, kura tiek plānota, īstenota un uzraudzīta } \\
\text { mijiedarbībā ar citiem resoriem. } \\
\text { 3. FM sadarbībā ar Valsts kanceleju izstrādāt vadlīnijas, ieklaut pārskata } \\
\text { struktūru. } \\
\text { 4. Ministriju un iestāžu iekšējā audita struktūrvienībām līdz 2019. gada 30. } \\
\text { janvārim iesniegt FM valsts pārvaldes uzdevumu deleǵēšanas IA ziñojumu, } \\
\text { ieteikumu ieviešanas grafiku un pārskatu, kas sagatavots atbilstoši vadlīnijās } \\
\text { noteiktajai struktūrai. Pārskatā par iekšējā audita struktūrvienības darbību } \\
\text { 2018. gadā iekḷaut informāciju par izpildi, norādot to ietekmējušos apstākḷus. } \\
\text { 5. FM apkopot ministriju un iestāžu iesniegto informāciju par iekšējā audita } \\
\text { rezultātiem un līdz 2019. gada 29. martam iesniegt Valsts kancelejā valsts } \\
\text { pārvaldes uzdevumu deleǵēšanas iekšējo auditu rezultātu apkopojumu }\end{array}$ \\
\hline
\end{tabular}

*Avots: autores veidota tabula, pamatojoties uz MK 25.10.2017. rīkojumu Nr. 605, MK 26.10.2016. rīkojumu Nr. 625, MK 01.10.2015. rīkojumu Nr. 609, MK 28.10.2014. rīkojumu Nr. 615, MK 04.12.2013. rīkojumu Nr. 591, MK 07.12.2012. rīkojumu Nr. 573. 
3. pielikums

\section{Latvijas pašvaldību aktīvi un ieṇēmumi no pamatdarbības kopsummas (milj. EUR) no 2013. gada līdz 2016. gadam}

\begin{tabular}{|c|c|c|c|c|c|c|c|c|c|c|}
\hline Pašvaldība & $\begin{array}{l}\text { Satis- } \\
\text { tiskais } \\
\text { reǵions }\end{array}$ & $\begin{array}{c}1-\text { ir } \\
\text { ieviesta } \\
\text { IAS, } \\
0-\text { nav } \\
\text { ieviesta } \\
\text { IAS }\end{array}$ & $\begin{array}{c}\text { leņē- } \\
\text { mumi, } \\
2013\end{array}$ & $\begin{array}{c}\text { leṇē- } \\
\text { mumi, } \\
2014\end{array}$ & $\begin{array}{l}\text { leṇē- } \\
\text { mumi, } \\
2015\end{array}$ & $\begin{array}{c}\text { leṇē- } \\
\text { mumi, } \\
2016\end{array}$ & $\begin{array}{c}\text { Aktivi, } \\
2013\end{array}$ & $\begin{array}{c}\text { Aktivi, } \\
2014\end{array}$ & $\begin{array}{c}\text { Aktīvi, } \\
2015\end{array}$ & $\begin{array}{c}\text { Aktivi, } \\
2016\end{array}$ \\
\hline Aglonas & 1 & 0 & 6,3 & 4,9 & 5,8 & 3,9 & 10 & 11 & 11,5 & 10,7 \\
\hline Aizkraukles & 2 & 0 & 17,2 & 12,1 & 9,5 & 9,1 & 39,0 & 38,0 & 36,8 & 36,0 \\
\hline Aizputes & 3 & 0 & 14,1 & 10,8 & 10,6 & 10,0 & 25,0 & 26,0 & 28,0 & 28,5 \\
\hline Aknīstes & 2 & 0 & 5,5 & 2,5 & 25,9 & 24,3 & 9,5 & 10,0 & 9,2 & 8,8 \\
\hline Alojas & 5 & 0 & 7,0 & 5,3 & 5,6 & 5,6 & 17,0 & 16,4 & 17,7 & 18,4 \\
\hline Alsungas & 3 & 0 & 1,8 & 1,6 & 1,5 & 1,5 & 3,6 & 3,4 & 3,1 & 3,0 \\
\hline Alūksnes & 4 & 0 & 20,9 & 20,7 & 22 & 17,0 & 45,8 & 49,7 & 52,5 & 51,5 \\
\hline Amatas & 4 & 0 & 11,9 & 6,7 & 7,5 & 7,9 & 13,9 & 14,6 & 15,0 & 15,4 \\
\hline Apes & 4 & 0 & 5,8 & 5,2 & 4,9 & 4,5 & 12,0 & 14,6 & 11,3 & 11,0 \\
\hline Auces & 2 & 0 & 9,4 & 7,1 & 7,0 & 6,9 & 14,9 & 14,7 & 13,1 & 12,4 \\
\hline Ādažu & 5 & 0 & 11,6 & 12,8 & 13,6 & 14,0 & 35,7 & 37 & 37,1 & 36,8 \\
\hline Babītes & 5 & 0 & 11,6 & 12,3 & 13,4 & 13,4 & 27,2 & 29,7 & 31,5 & 32,8 \\
\hline Baldones & 5 & 0 & 5,4 & 5,1 & 5,4 & 5,8 & 14,0 & 13,9 & 14,6 & 13,9 \\
\hline Baltinavas & 1 & 0 & 2,4 & 1,8 & 1,7 & 1,3 & 3,7 & 4,1 & 3,9 & 3,9 \\
\hline Balvu & 1 & 0 & 22,0 & 17,0 & 16,6 & 15,4 & 44 & 45,5 & 44,7 & 43,1 \\
\hline Bauskas & 2 & 0 & 28,1 & 29,5 & 26,5 & 26,1 & 69,8 & 76,7 & 75,4 & 76,2 \\
\hline Beverīnas & 4 & 0 & 5,5 & 3,2 & 2,9 & 3,3 & 9,5 & 9,0 & 8,5 & 8,4 \\
\hline Brocēnu & 3 & 1 & 9,0 & 7,6 & 28,3 & 6,6 & 10,7 & 11,6 & 33,5 & 31,7 \\
\hline Burtnieku & 4 & 0 & 10,2 & 6,8 & 6,3 & 6,3 & 22,2 & 24,4 & 23,0 & 23,0 \\
\hline Carnikavas & 5 & 0 & 13,6 & 12,2 & 11,7 & 10,5 & 20,9 & 27,1 & 29,8 & 30,6 \\
\hline Cesvaines & 4 & 0 & 8,7 & 3,8 & 3,2 & 3,3 & 13,6 & 13,9 & 13,6 & 13,4 \\
\hline Cēsu & 4 & 1 & 45 & 27,6 & 28,0 & 24,1 & 100,1 & 104,0 & 103,7 & 102,5 \\
\hline Ciblas & 1 & 0 & 4,6 & 3,8 & 3,2 & 2,9 & 6,5 & 7,1 & 7,3 & 7,2 \\
\hline Dagdas & 1 & 0 & 10,7 & 9,1 & 9,0 & 8,7 & 19,5 & 19,1 & 18,4 & 17,6 \\
\hline Daugavpils & 1 & 1 & 35,7 & 27,9 & 26,9 & 22,9 & 67,9 & 77,7 & 76,1 & 73,3 \\
\hline DAUGAVPILS * & 1 & 1 & 132 & 86,8 & 84,8 & 83,8 & 269,2 & 278,7 & 275,1 & 275,6 \\
\hline Dobeles & 2 & 0 & 31,5 & 22,8 & 23,7 & 22,6 & 71,9 & 73,9 & 73,8 & 73,7 \\
\hline Dundagas & 3 & 0 & 4,1 & 4,2 & 4,0 & 4,2 & 8,3 & 8,2 & 7,8 & 7,9 \\
\hline Durbes & 3 & 0 & 4,2 & 2,9 & 2,6 & 2,5 & 9,7 & 9,6 & 9,0 & 8,5 \\
\hline Engures & 5 & 0 & 11,2 & 10,5 & 9,5 & 9,6 & 27,6 & 28,5 & 28,4 & 28,2 \\
\hline Ërglı & 4 & 0 & 5,4 & 3,1 & 3,3 & 3,3 & 8,8 & 8,5 & 8,0 & 8,0 \\
\hline Garkalnes & 5 & 0 & 12,1 & 11,2 & 12,6 & 12,2 & 19,2 & 20,6 & 22,0 & 22,6 \\
\hline Grobinas & 3 & 0 & 9,9 & 9,3 & 10,4 & 9,7 & 22,1 & 24,1 & 25,6 & 25,6 \\
\hline Gulbenes & 4 & 0 & 36,8 & 26,2 & 26,7 & 26 & 63,3 & 67,0 & 65,7 & 62,0 \\
\hline lecavas & 2 & 1 & 11,1 & 10,0 & 10,6 & 10,7 & 17,7 & 17,6 & 18,9 & 19,4 \\
\hline Ikšksiles & 5 & 0 & 10,3 & 10,7 & 10,9 & 11,5 & 21,6 & 23,3 & 22,2 & 21,5 \\
\hline Ilūkstes & 1 & 0 & 15,1 & 8,5 & 8,0 & 7,5 & 27,5 & 27,4 & 26,6 & 25,8 \\
\hline Inčukalna & 5 & 0 & 9,5 & 7,0 & 7,0 & 7,4 & 16,9 & 17,3 & 17,4 & 17,6 \\
\hline
\end{tabular}


3. pielikuma turpinājums

\begin{tabular}{|c|c|c|c|c|c|c|c|c|c|c|}
\hline Pašvaldība & $\begin{array}{l}\text { Satis- } \\
\text { tiskais } \\
\text { reǵions }\end{array}$ & $\begin{array}{c}1-\text { ir } \\
\text { ieviesta } \\
\text { IAS, } \\
0-\text { nav } \\
\text { ieviesta } \\
\text { IAS } \\
\end{array}$ & $\begin{array}{l}\text { leṇē- } \\
\text { mumi, } \\
2013\end{array}$ & $\begin{array}{c}\text { leñē- } \\
\text { mumi, } \\
2014\end{array}$ & $\begin{array}{l}\text { leṇē- } \\
\text { mumi, } \\
2015\end{array}$ & $\begin{array}{c}\text { leṇē- } \\
\text { mumi, } \\
2016\end{array}$ & $\begin{array}{c}\text { Aktīvi, } \\
2013\end{array}$ & $\begin{array}{c}\text { Aktīvi, } \\
2014\end{array}$ & $\begin{array}{c}\text { Aktīvi, } \\
2015\end{array}$ & $\begin{array}{c}\text { Aktīvi, } \\
2016\end{array}$ \\
\hline Jaunjelgavas & 2 & 0 & 14,4 & 7,5 & 6,5 & 5,6 & 20,0 & 23,0 & 22,1 & 21,0 \\
\hline Jaunpiebalgas & 4 & 0 & 4,9 & 2,5 & 2,7 & 2,6 & 8,1 & 7,8 & 7,7 & 7,8 \\
\hline Jaunpils & 5 & 0 & 2,3 & 2,5 & 2,5 & 2,5 & 5,4 & 6,1 & 6,8 & 6,5 \\
\hline Jelgavas & 2 & 1 & 32,7 & 24,5 & 24,0 & 24,4 & 74,3 & 78,6 & 78,6 & 78,9 \\
\hline JELGAVA* & 2 & 1 & 81,8 & 64,9 & 56,9 & 78,3 & 219,1 & 228,8 & 226,5 & 237,4 \\
\hline Jēkabpils & 2 & 0 & 7,1 & 4,8 & 4,7 & 4,8 & 15,7 & 15,4 & 15,0 & 14,8 \\
\hline JËKABPILS* & 2 & 1 & 26,2 & 23,2 & 22,1 & 21,0 & 72,0 & 74,3 & 73,6 & 74,0 \\
\hline JŪRMALA* & 5 & 1 & 109,3 & 68,1 & 73,5 & 76,0 & 245,8 & 257,5 & 273,8 & 274,7 \\
\hline Kandavas & 5 & 0 & 10,3 & 11,5 & 9,9 & 9,9 & 19,7 & 20,8 & 20,8 & 20,1 \\
\hline Kārsavas & 1 & 0 & 9,3 & 6,1 & 6,0 & 5,2 & 14,3 & 15,0 & 14,8 & 15,3 \\
\hline Kocēnu & 4 & 0 & 10,7 & 7,4 & 7,4 & 7,8 & 25,9 & 26,4 & 27,1 & 28,0 \\
\hline Kokneses & 2 & 0 & 9,6 & 8,2 & 8,0 & 8,0 & 17,5 & 18,4 & 17,9 & 17,8 \\
\hline Krāslavas & 1 & 0 & 27,8 & 21,0 & 16,7 & 15,3 & 63,1 & 62,4 & 62,1 & 60,1 \\
\hline Krimuldas & 5 & 0 & 8,0 & 5,6 & 4,7 & 5,4 & 15,1 & 15,4 & 14,7 & 14,3 \\
\hline Krustpils & 2 & 0 & 8,0 & 8,3 & 7,9 & 7,6 & 15,3 & 15,8 & 17,0 & 16,7 \\
\hline Kuldīgas & 3 & 0 & 58,4 & 26,9 & 28 & 27,4 & 99,0 & 95,3 & 94,8 & 93,8 \\
\hline Ķeguma & 5 & 0 & 6,0 & 5,4 & 4,8 & 5,2 & 14,4 & 14,8 & 13,9 & 13,8 \\
\hline Ķekavas & 5 & 1 & 26,8 & 25,7 & 27,1 & 28,7 & 53,4 & 59,6 & 63,0 & 71,3 \\
\hline Lielvārdes & 5 & 1 & 10,3 & 9,8 & 10,7 & 11,0 & 24,7 & 26,2 & 25,7 & 22,5 \\
\hline LIEPĀJA* & 3 & 1 & 114,9 & 227,3 & 103,4 & 89,3 & 500,9 & 430,6 & 383,4 & 368,1 \\
\hline Limbažu & 5 & 1 & 29,4 & 17,5 & 21,3 & 18,2 & 55,1 & 56,6 & 55,9 & 55,5 \\
\hline Līgatnes & 4 & 0 & 6,6 & 3,8 & 3,5 & 3,2 & 13,6 & 13,2 & 12,7 & 12,3 \\
\hline Līvānu & 1 & 0 & 23,7 & 14,9 & 15,9 & 12,4 & 45,4 & 46,6 & 47,0 & 47,7 \\
\hline Lubānas & 4 & 0 & 4,0 & 2,4 & 2,4 & 2,5 & 5,2 & 5,3 & 5,5 & 5,3 \\
\hline Ludzas & 1 & 0 & 20,9 & 15,6 & 14,6 & 13,0 & 47,1 & 46,7 & 45,4 & 44,5 \\
\hline Madonas & 4 & 1 & 28,8 & 27,6 & 28,8 & 27,5 & 88,3 & 91,4 & 85,0 & 84,4 \\
\hline Mazsalacas & 4 & 0 & 4,8 & 3,2 & 3,4 & 3,0 & 13,1 & 13,2 & 13,1 & 10,3 \\
\hline Mālpils & 5 & 0 & 6,0 & 4,9 & 4,6 & 4,9 & 13,8 & 13,7 & 13,3 & 13,0 \\
\hline Mārupes & 5 & 1 & 23,6 & 25,2 & 24,3 & 26,1 & 44,0 & 51,8 & 68,1 & 70,4 \\
\hline Mērsraga & 3 & 0 & 2,6 & 1,6 & 1,7 & 1,4 & 3,3 & 3,4 & 32,1 & 3,0 \\
\hline Naukšēnu & 4 & 0 & 2,5 & 2,1 & 2,1 & 2,1 & 5,0 & 5,0 & 51,2 & 5,0 \\
\hline Neretas & 2 & 0 & 7,7 & 3,9 & 3,6 & 3,8 & 10,5 & 10,3 & 9,7 & 9,4 \\
\hline Nìcas & 3 & 0 & 5,7 & 4,2 & 4,0 & 5,1 & 7,2 & 8,2 & 11,3 & 12,6 \\
\hline Ogres & 5 & 0 & 64,2 & 58,7 & 46,7 & 53,1 & 119,5 & 136,7 & 134,6 & 135,0 \\
\hline Olaines & 5 & 0 & 21,8 & 18,2 & 18,2 & 18,6 & 52,1 & 55,2 & 55,5 & 57,4 \\
\hline Ozolnieku & 2 & 0 & 10,9 & 10,7 & 10,9 & 12,2 & 27,6 & 28,9 & 28,2 & 28,8 \\
\hline Pārgaujas & 4 & 0 & 5,8 & 4,7 & 4,6 & 4,9 & 9,5 & 9,5 & 9,1 & 9,3 \\
\hline Pāvilostas & 3 & 0 & 4,3 & 2,7 & 2,8 & 2,8 & 10,5 & 9,7 & 9,2 & 9,2 \\
\hline Pḷaviņu & 2 & 0 & 10,0 & 5,3 & 5,4 & 4,9 & 15,8 & 16,4 & 15,9 & 16,0 \\
\hline Preilu & 1 & 0 & 11,8 & 11,6 & 10,6 & 10,6 & 26,6 & 28,9 & 28,0 & 27,6 \\
\hline Priekules & 3 & 0 & 8,2 & 7,6 & 6,8 & 6,4 & 19,7 & 19,4 & 19,5 & 19,2 \\
\hline Priekulu & 4 & 0 & 15,0 & 9,8 & 8,7 & 8,7 & 23,2 & 23,2 & 22,5 & 22,3 \\
\hline
\end{tabular}


3. pielikuma turpinājums

\begin{tabular}{|c|c|c|c|c|c|c|c|c|c|c|}
\hline Pašvaldība & $\begin{array}{l}\text { Satis- } \\
\text { tiskais } \\
\text { reǵions }\end{array}$ & $\begin{array}{c}1-\text { ir } \\
\text { ieviesta } \\
\text { IAS, } \\
0-\text { nav } \\
\text { ieviesta } \\
\text { IAS }\end{array}$ & $\begin{array}{c}\text { leṇē- } \\
\text { mumi, } \\
2013\end{array}$ & $\begin{array}{c}\text { leṇē- } \\
\text { mumi, } \\
2014\end{array}$ & $\begin{array}{l}\text { leṇē- } \\
\text { mumi, } \\
2015\end{array}$ & $\begin{array}{c}\text { leṇē- } \\
\text { mumi, } \\
2016\end{array}$ & $\begin{array}{l}\text { Aktīvi, } \\
2013\end{array}$ & $\begin{array}{l}\text { Aktīvi, } \\
2014\end{array}$ & $\begin{array}{l}\text { Aktīvi, } \\
2015\end{array}$ & $\begin{array}{c}\text { Aktīvi, } \\
2016\end{array}$ \\
\hline Raunas & 4 & 0 & 9,9 & 3,5 & 3,8 & 3,6 & 10,2 & 9,9 & 9,6 & 8,9 \\
\hline Rēzeknes & 1 & 0 & 49,7 & 31,0 & 31,8 & 35,9 & 61,8 & 68,4 & 72,6 & 73,1 \\
\hline RĒZEKNE* & 1 & 1 & 60,0 & 35,3 & 37,0 & 34,0 & 130,1 & 131,0 & 133,0 & 134,5 \\
\hline Riebingu & 1 & 0 & 6,1 & 5,7 & 4,8 & 4,7 & 19,4 & 20,9 & 20,5 & 19,9 \\
\hline RĪGA* & 6 & 1 & 773,0 & 755,9 & 825,9 & 915,5 & 3486,5 & 3425 & 3392,7 & 3411 \\
\hline Rojas & 3 & 0 & 6,5 & 3,4 & 3,4 & 3,5 & 9,3 & 9,2 & 8,9 & 8,9 \\
\hline Ropažu & 5 & 0 & 5,7 & 5,4 & 5,8 & 6,0 & 15,1 & 16,6 & 17,6 & 20,2 \\
\hline Rucavas & 3 & 0 & 3,9 & 1,7 & 1,8 & 1,9 & 7,8 & 7,4 & 7,6 & 7,6 \\
\hline Rugāju & 1 & 0 & 3,4 & 2,7 & 2,3 & 2,4 & 8,0 & 7,9 & 7,8 & 7,8 \\
\hline Rundāles & 2 & 0 & 5,5 & 5,4 & 5,0 & 4,0 & 11,3 & 13,0 & 13,7 & 14,0 \\
\hline Rūjienas & 4 & 0 & 5,9 & 5,8 & 8,1 & 6,2 & 19,4 & 20,4 & 21,6 & 21,4 \\
\hline Salacgrīvas & 5 & 0 & 14,5 & 7,9 & 7,7 & 7,7 & 26,7 & 27,9 & 27,3 & 27,1 \\
\hline Salas & 2 & 0 & 6,2 & 4,7 & 4,5 & 4,2 & 7,4 & 7,3 & 7,0 & 6,6 \\
\hline Salaspils & 5 & 0 & 21,3 & 21,4 & 21,3 & 22,4 & 63,3 & 66,2 & 67,8 & 74,7 \\
\hline Saldus & 3 & 1 & 48,9 & 33,1 & 29,4 & 28,4 & 88,6 & 92,3 & 94,9 & 92,3 \\
\hline Saulkrastu & 5 & 0 & 9,3 & 8,8 & 17 & 7,7 & 22,8 & 24,1 & 33,5 & 32,7 \\
\hline Sējas & 5 & 0 & 4,2 & 3,1 & 2,7 & 2,5 & 8,4 & 9,1 & 9,0 & 8,9 \\
\hline Siguldas & 5 & 0 & 33,4 & 18,7 & 22,8 & 19,1 & 51,6 & 51,4 & 54,2 & 59,6 \\
\hline Skrīveru & 2 & 0 & 4,7 & 3,9 & 3,8 & 4,0 & 8,3 & 8,0 & 7,8 & 7,7 \\
\hline Skrundas & 3 & 0 & 6,0 & 6,5 & 8,0 & 6,3 & 14,1 & 16,4 & 17,4 & 17,0 \\
\hline Smiltenes & 4 & 0 & 16,1 & 13,2 & 13,3 & 13,8 & 44,9 & 45,2 & 43,9 & 40,9 \\
\hline Stopinu & 5 & 0 & 21,7 & 18,1 & 19,5 & 17,4 & 35,0 & 38,0 & 38,7 & 40,0 \\
\hline Strenču & 4 & 0 & 7,5 & 5,9 & 4,8 & 3,7 & 13,3 & 15,6 & 14,6 & 14,1 \\
\hline Talsu & 3 & 1 & 43,6 & 33,5 & 32,9 & 31,1 & 98,3 & 98,1 & 94,7 & 94,7 \\
\hline Tērvetes & 2 & 0 & 4,8 & 4,4 & 4,4 & 4,6 & 8,4 & 9,4 & 9,5 & 9,3 \\
\hline Tukuma & 5 & 1 & 50,2 & 31,2 & 36,4 & 31,5 & 81 & 82,5 & 84,3 & 84,4 \\
\hline Vain,odes & 3 & 0 & 5,6 & 3,6 & 5,1 & 3,5 & 8,1 & 8,5 & 8,4 & 8,3 \\
\hline Valkas & 4 & 1 & 21,5 & 11,0 & 13,4 & 10,4 & 37,5 & 39,7 & 40,8 & 42,3 \\
\hline VALMIERA * & 4 & 1 & 57,4 & 29,4 & 31,5 & 30,4 & 110,6 & 108 & 108,8 & 113,4 \\
\hline Varakḷānu & 4 & 0 & 5,1 & 3,3 & 3,4 & 3,3 & 9,9 & 9,7 & 9,6 & 9,3 \\
\hline Vārkavas & 1 & 0 & 1,8 & 2,7 & 1,9 & 1,7 & 3,3 & 3,3 & 3,2 & 3,2 \\
\hline Vecpiebalgas & 4 & 0 & 6,0 & 4,6 & 4,9 & 4,5 & 13,2 & 13,8 & 13,3 & 12,2 \\
\hline Vecumnieku & 2 & 0 & 11,1 & 8,3 & 9,3 & 13,2 & 16,7 & 18,0 & 17,9 & 23,0 \\
\hline VENTSPILS* & 3 & 0 & 79,5 & 47,4 & 49,2 & 46,1 & 415,3 & 412 & 408,7 & 401,8 \\
\hline Viesītes & 2 & 0 & 6,5 & 4,5 & 3,7 & 3,8 & 7,2 & 9,3 & 9,0 & 9,5 \\
\hline Viḷakas & 1 & 0 & 11,0 & 5,9 & 5,7 & 5,2 & 13,9 & 14,1 & 14,4 & 14,5 \\
\hline Viḷānu & 1 & 0 & 6,6 & 7,1 & 7,7 & 5,7 & 15,8 & 17,4 & 18,9 & 18,3 \\
\hline Zilupes & 1 & 0 & 5,9 & 3,1 & 3,2 & 2,2 & 5,4 & 5,8 & 6,0 & 5,9 \\
\hline Ventspils & 3 & 0 & 16,7 & 16,5 & 14,3 & 14,1 & 36,2 & 40,4 & 38,0 & 37,8 \\
\hline
\end{tabular}

* Republikas nozīmes pilsētas 
4. pielikums

\section{Pašvaldību ieṇēmumu un aktīvu summu galvenie statistiskie rādītāji}

Pašvaldību ieṇēmumu un aktīvu summu galvenie statistiskie rādītāji (milj. EUR), grupējot atbilstoši tam, vai ir ieviesta vai nav ieviesta IAS (2013-2016)

\begin{tabular}{|c|c|c|c|c|c|c|c|}
\hline & & $\begin{array}{l}\text { Aritmē- } \\
\text { tiskais } \\
\text { vidējais }\end{array}$ & Mediāna & $\begin{array}{c}\text { Standart- } \\
\text { novirze }\end{array}$ & $\begin{array}{c}\text { Variācijas } \\
\text { amplitūda }\end{array}$ & $\begin{array}{l}\text { Mini- } \\
\text { mums }\end{array}$ & $\begin{array}{l}\text { Maksi- } \\
\text { mums }\end{array}$ \\
\hline \multirow{8}{*}{$\begin{array}{l}\text { Nav } \\
\text { ieviesta } \\
\text { IAS } \\
(N=97)\end{array}$} & leņēmumi (2013, milj. EUR) & 12,37 & 8,20 & 12,90 & 77,7 & 1,8 & 79,5 \\
\hline & leņēmumi (2014, milj. EUR) & 9,30 & 5,90 & 9,15 & 57,1 & 1,6 & 58,7 \\
\hline & leņēmumi (2015, milj. EUR) & 9,46 & 6,30 & 8,85 & 47,7 & 1,5 & 49,2 \\
\hline & Ieņēmumi (2016, milj. EUR) & 9,11 & 5,80 & 8,93 & 51,8 & 1,3 & 53,1 \\
\hline & Aktīvi (2013, milj. EUR) & 26,68 & 15,30 & 44,85 & 412,0 & 3,3 & 415,3 \\
\hline & Aktīvi (2014, milj. EUR) & 27,72 & 16,40 & 45,07 & 408,7 & 3,3 & 412,0 \\
\hline & Aktīvi (2015, milj. EUR) & 28,55 & 17,40 & 44,71 & 405,6 & 3,1 & 408,7 \\
\hline & Aktīvi (2016, milj. EUR) & 27,69 & 16,70 & 44,26 & 398,8 & 3,0 & 401,8 \\
\hline \multirow{8}{*}{$\begin{array}{l}\text { Ir } \\
\text { ieviesta } \\
\text { IAS } \\
(N=22)\end{array}$} & leņēmumi (2013, milj. EUR) & 80,51 & 39,65 & 158,37 & 764,0 & 9,0 & 773,0 \\
\hline & leņēmumi (2014, milj. EUR) & 72,87 & 27,75 & 159,36 & 748,3 & 7,6 & 755,9 \\
\hline & leṇēmumi (2015, milj. EUR) & 71,69 & 28,55 & 170,10 & 815,3 & 10,6 & 825,9 \\
\hline & leṇēmumi (2016, milj. EUR) & 74,09 & 27,95 & 189,52 & 908,9 & 6,6 & 915,5 \\
\hline & Aktīvi (2013, milj. EUR) & 267,08 & 84,65 & 727,51 & 3475,8 & 10,7 & 3486,5 \\
\hline & Aktīvi (2014, milj. EUR) & 264,60 & 86,95 & 712,88 & 3413,0 & 11,6 & 3424,6 \\
\hline & Aktīvi (2015, milj. EUR) & 263,19 & 84,65 & 705,12 & 3373,8 & 18,9 & 3392,7 \\
\hline & Aktīvi (2016, milj. EUR) & 264,20 & 84,40 & 708,78 & 3391,6 & 19,4 & 3411,0 \\
\hline
\end{tabular}


Pašvaldību ieṇēmumu un aktīvu summu galvenie statistiskie rādītāji (milj. EUR), grupējot atbilstoši tam, vai ir ieviesta vai nav ieviesta IAS (2013-2016); bez Rīgas

\begin{tabular}{|c|c|c|c|c|c|c|c|}
\hline & & $\begin{array}{c}\text { Aritmētis- } \\
\text { kais vidējais }\end{array}$ & Mediāna & $\begin{array}{c}\text { Standart- } \\
\text { novirze }\end{array}$ & $\begin{array}{c}\text { Variācijas } \\
\text { amplitūda }\end{array}$ & $\begin{array}{l}\text { Mini- } \\
\text { mums }\end{array}$ & $\begin{array}{l}\text { Maksi- } \\
\text { mums }\end{array}$ \\
\hline \multirow{8}{*}{$\begin{array}{l}\text { Nav } \\
\text { ieviesta } \\
\text { IAS } \\
(N=97)\end{array}$} & Ieņēmumi (2013, milj. EUR) & 12,37 & 8,20 & 12,90 & 77,7 & 1,8 & 79,5 \\
\hline & leṇēmumi (2014, milj. EUR) & 9,30 & 5,90 & 9,15 & 57,1 & 1,6 & 58,7 \\
\hline & leņēmumi (2015, milj. EUR) & 9,46 & 6,30 & 8,85 & 47,7 & 1,5 & 49,2 \\
\hline & leņēmumi (2016, milj. EUR) & 9,11 & 5,80 & 8,93 & 51,8 & 1,3 & 53,1 \\
\hline & Aktīvi (2013, milj. EUR) & 26,68 & 15,30 & 44,85 & 412,0 & 3,3 & 415,3 \\
\hline & Aktīvi (2014, milj. EUR) & 27,72 & 16,40 & 45,07 & 408,7 & 3,3 & 412,0 \\
\hline & Aktīvi (2015, milj. EUR) & 28,55 & 17,40 & 44,71 & 405,6 & 3,1 & 408,7 \\
\hline & Aktīvi (2016, milj. EUR) & 27,69 & 16,70 & 44,26 & 398,8 & 3,0 & 401,8 \\
\hline \multirow{8}{*}{$\begin{array}{l}\text { Ir ievies- } \\
\text { ta IAS } \\
(N=21)\end{array}$} & leņēmumi (2013, milj. EUR) & 47,53 & 35,70 & 34,87 & 123,0 & 9,0 & 132,0 \\
\hline & leņēmumi (2014, milj. EUR) & 40,34 & 27,60 & 47,22 & 219,7 & 7,6 & 227,3 \\
\hline & leņēmumi (2015, milj. EUR) & 35,78 & 28,30 & 24,15 & 92,8 & 10,6 & 103,4 \\
\hline & len̦ēmumi (2016, milj. EUR) & 34,02 & 27,50 & 25,07 & 82,7 & 6,6 & 89,3 \\
\hline & Aktīvi (2013, milj. EUR) & 113,78 & 81,00 & 113,26 & 490,2 & 10,7 & 500,9 \\
\hline & Aktīvi (2014, milj. EUR) & 114,12 & 82,50 & 102,73 & 419,0 & 11,6 & 430,6 \\
\hline & Aktīvi (2015, milj. EUR) & 114,16 & 84,30 & 95,07 & 364,5 & 18,9 & 383,4 \\
\hline & Aktīvi $(2016$, milj. EUR) & 114,35 & 84,40 & 93,74 & 348,7 & 19,4 & 368,1 \\
\hline
\end{tabular}

Pašvaldību ieṇēmumu un aktīvu summu galvenie statistiskie rādītāji (milj. EUR), grupējot atbilstoši tam, vai ir ieviesta vai nav ieviesta IAS (2013-2016); bez lielajām pilsētām

\begin{tabular}{|c|c|c|c|c|c|c|c|}
\hline & & $\begin{array}{c}\text { Aritmētis- } \\
\text { kais vidējais }\end{array}$ & Mediāna & $\begin{array}{c}\text { Standart- } \\
\text { novirze }\end{array}$ & $\begin{array}{c}\text { Variācijas } \\
\text { amplitūda }\end{array}$ & $\begin{array}{l}\text { Mini- } \\
\text { mums }\end{array}$ & $\begin{array}{l}\text { Maksi- } \\
\text { mums }\end{array}$ \\
\hline \multirow{8}{*}{$\begin{array}{l}\text { Nav } \\
\text { ieviesta } \\
\text { IAS } \\
(N=96)\end{array}$} & Ieṇēmumi (2013, milj. EUR) & 11,67 & 8,10 & 10,96 & 62,4 & 1,8 & 64,2 \\
\hline & leņēmumi (2014, milj. EUR) & 8,91 & 5,90 & 8,32 & 57,1 & 1,6 & 58,7 \\
\hline & Ieṇēmumi (2015, milj. EUR) & 9,05 & 6,15 & 7,90 & 45,2 & 1,5 & 46,7 \\
\hline & leņēmumi (2016, milj. EUR) & 8,73 & 5,75 & 8,13 & 51,8 & 1,3 & 53,1 \\
\hline & Aktīvi (2013, milj. EUR) & 22,63 & 15,20 & 20,64 & 116,2 & 3,3 & 119,5 \\
\hline & Aktīvi (2014, milj. EUR) & 23,72 & 16,10 & 21,95 & 133,4 & 3,3 & 136,7 \\
\hline & Aktīvi (2015, milj. EUR) & 24,59 & 17,40 & 21,98 & 131,5 & 3,1 & 134,6 \\
\hline & Aktīvi (2016, milj. EUR) & 23,79 & 16,35 & 22,17 & 132,0 & 3,0 & 135,0 \\
\hline \multirow{8}{*}{$\begin{array}{l}\text { Ir } \\
\text { ieviesta } \\
\text { IAS } \\
(N=14)\end{array}$} & Ieṇēmumi (2013, milj. EUR) & 29,76 & 29,10 & 13,94 & 41,2 & 9,0 & 50,2 \\
\hline & leṇēmumi (2014, milj. EUR) & 22,30 & 25,45 & 9,23 & 25,9 & 7,6 & 33,5 \\
\hline & leṇēmumi (2015, milj. EUR) & 24,44 & 27,00 & 7,90 & 25,8 & 10,6 & 36,4 \\
\hline & Ieņēmumi (2016, milj. EUR) & 21,54 & 24,25 & 8,54 & 24,9 & 6,6 & 31,5 \\
\hline & Aktīvi (2013, milj. EUR) & 60,11 & 61,50 & 30,00 & 89,4 & 10,7 & 100,1 \\
\hline & Aktīvi (2014, milj. EUR) & 63,41 & 68,65 & 30,63 & 92,4 & 11,6 & 104,0 \\
\hline & Aktīvi (2015, milj. EUR) & 65,94 & 72,10 & 27,30 & 84,8 & 18,9 & 103,7 \\
\hline & Aktīvi (2016, milj. EUR) & 65,97 & 72,30 & 27,32 & 83,1 & 19,4 & 102,5 \\
\hline
\end{tabular}


4. pielikuma turpinājums 4. tabula

Pašvaldību ieṇēmumu un aktīvu summu galvenie statistiskie rādītāji (milj. EUR), grupējot atbilstoši tam, vai ir ieviesta vai nav ieviesta IAS (2013-2016); Latgales statistiskais reġions

\begin{tabular}{|c|c|c|c|c|c|c|c|}
\hline & & $\begin{array}{c}\text { Aritmētis- } \\
\text { kais vidējais }\end{array}$ & Mediāna & \begin{tabular}{|c} 
Standart- \\
novirze
\end{tabular} & $\begin{array}{l}\text { Variācijas } \\
\text { amplitūda }\end{array}$ & $\begin{array}{l}\text { Mini- } \\
\text { mums }\end{array}$ & $\begin{array}{l}\text { Maksi- } \\
\text { mums }\end{array}$ \\
\hline \multirow{8}{*}{$\begin{array}{l}\text { Nav } \\
\text { ieviesta } \\
\text { IAS } \\
(N=18)\end{array}$} & leṇēmumi (2013, milj. EUR) & 13,28 & 10,00 & 11,97 & 47,9 & 1,8 & 49,7 \\
\hline & Ien̦ēmumi (2014, milj. EUR) & 9,58 & 6,60 & 7,72 & 29,2 & 1,8 & 31,0 \\
\hline & leṇēmumi (2015, milj. EUR) & 9,19 & 6,85 & 7,60 & 30,1 & 1,7 & 31,8 \\
\hline & Ien̦ēmumi (2016, milj. EUR) & 8,56 & 5,45 & 8,25 & 34,6 & 1,3 & 35,9 \\
\hline & Aktīvi (2013, milj. EUR) & 24,18 & 17,60 & 19,73 & 59,8 & 3,3 & 63,1 \\
\hline & Aktīvi (2014, milj. EUR) & 25,09 & 18,25 & 20,40 & 65,1 & 3,3 & 68,4 \\
\hline & Aktīvi (2015, milj. EUR) & 25,17 & 18,65 & 20,77 & 69,4 & 3,2 & 72,6 \\
\hline & Aktīvi (2016, milj. EUR) & 24,79 & 17,95 & 20,59 & 69,9 & 3,2 & 73,1 \\
\hline \multirow{8}{*}{$\begin{array}{l}\text { Ir } \\
\text { ieviesta } \\
\text { IAS } \\
(N=3)\end{array}$} & leņēmumi (2013, milj. EUR) & 75,90 & 60,00 & 50,08 & 96,3 & 35,7 & 132,0 \\
\hline & leṇēmumi (2014, milj. EUR) & 50,00 & 35,30 & 32,08 & 58,9 & 27,9 & 86,8 \\
\hline & leṇēmumi (2015, milj. EUR) & 49,57 & 37,00 & 30,93 & 57,9 & 26,9 & 84,8 \\
\hline & leṇēmumi (2016, milj. EUR) & 46,90 & 34,00 & 32,43 & 60,9 & 22,9 & 83,8 \\
\hline & Aktīvi (2013, milj. EUR) & 155,73 & 130,10 & 103,07 & 201,3 & 67,9 & 269,2 \\
\hline & Aktīvi (2014, milj. EUR) & 162,47 & 131,00 & 104,13 & 201,0 & 77,7 & 278,7 \\
\hline & Aktīvi (2015, milj. EUR) & 161,40 & 133,00 & 102,49 & 199,0 & 76,1 & 275,1 \\
\hline & Aktīvi (2016, milj. EUR) & 161,13 & 134,50 & 103,75 & 202,3 & 73,3 & 275,6 \\
\hline
\end{tabular}

5. tabula

Pašvaldību ieṇēmumu un aktīvu summu galvenie statistiskie rādītāji (milj. EUR), grupējot atbilstoši tam, vai ir ieviesta vai nav ieviesta IAS (2013-2016); Zemgales statistiskais reǵions

\begin{tabular}{|c|c|c|c|c|c|c|c|}
\hline & & $\begin{array}{l}\text { Aritmētis- } \\
\text { kais vidējais }\end{array}$ & Mediāna & $\begin{array}{c}\text { Standart- } \\
\text { novirze }\end{array}$ & $\begin{array}{c}\text { Variācijas } \\
\text { amplitūda }\end{array}$ & $\begin{array}{l}\text { Mini- } \\
\text { mums }\end{array}$ & $\begin{array}{l}\text { Maksi- } \\
\text { mums }\end{array}$ \\
\hline \multirow{8}{*}{$\begin{array}{l}\text { Nav } \\
\text { ieviesta } \\
\text { IAS } \\
(N=18)\end{array}$} & leṇēmumi (2013, milj. EUR) & 11,01 & 8,70 & 7,61 & 26,8 & 4,7 & 31,5 \\
\hline & leṇēmumi (2014, milj. EUR) & 8,55 & 6,25 & 6,97 & 27,0 & 2,5 & 29,5 \\
\hline & leņēmumi (2015, milj. EUR) & 9,46 & 6,75 & 7,65 & 22,9 & 3,6 & 26,5 \\
\hline & leņēmumi (2016, milj. EUR) & 9,43 & 6,25 & 7,42 & 22,3 & 3,8 & 26,1 \\
\hline & Aktīvi (2013, milj. EUR) & 21,49 & 15,50 & 19,59 & 64,7 & 7,2 & 71,9 \\
\hline & Aktīvi (2014, milj. EUR) & 22,58 & 15,60 & 20,69 & 69,4 & 7,3 & 76,7 \\
\hline & Aktīvi (2015, milj. EUR) & 22,17 & 15,45 & 20,51 & 68,4 & 7,0 & 75,4 \\
\hline & Aktīvi (2016, milj. EUR) & 22,32 & 15,40 & 20,63 & 69,6 & 6,6 & 76,2 \\
\hline \multirow{8}{*}{$\begin{array}{l}\text { Ir } \\
\text { ieviesta } \\
\text { IAS } \\
(N=4)\end{array}$} & leṇēmumi (2013, milj. EUR) & 37,95 & 29,45 & 30,60 & 70,7 & 11,1 & 81,8 \\
\hline & leṇēmumi (2014, milj. EUR) & 30,65 & 23,85 & 23,75 & 54,9 & 10,0 & 64,9 \\
\hline & leṇēmumi (2015, milj. EUR) & 28,40 & 23,05 & 19,90 & 46,3 & 10,6 & 56,9 \\
\hline & leṇēmumi (2016, milj. EUR) & 33,60 & 22,70 & 30,36 & 67,6 & 10,7 & 78,3 \\
\hline & Aktīvi (2013, milj. EUR) & 95,78 & 73,15 & 86,28 & 201,4 & 17,7 & 219,1 \\
\hline & Aktīvi (2014, milj. EUR) & 99,83 & 76,45 & 90,37 & 211,2 & 17,6 & 228,8 \\
\hline & Aktīvi (2015, milj. EUR) & 99,40 & 76,10 & 88,94 & 207,6 & 18,9 & 226,5 \\
\hline & Aktīvi (2016, milj. EUR) & 102,43 & 76,45 & 93,94 & 218,0 & 19,4 & 237,4 \\
\hline
\end{tabular}


Pašvaldību ieṇēmumu un aktīvu summu galvenie statistiskie rādītāji (milj. EUR), grupējot atbilstoši tam, vai ir ieviesta vai nav ieviesta IAS (2013-2016); Kurzemes statistiskais reǵions

\begin{tabular}{|c|c|c|c|c|c|c|c|}
\hline & & $\begin{array}{c}\text { Aritmētis- } \\
\text { kais vidējais }\end{array}$ & Mediāna & $\begin{array}{c}\text { Standart- } \\
\text { novirze }\end{array}$ & $\begin{array}{l}\text { Variācijas } \\
\text { amplitūda }\end{array}$ & $\begin{array}{l}\text { Mini- } \\
\text { mums }\end{array}$ & $\begin{array}{l}\text { Maksi- } \\
\text { mums }\end{array}$ \\
\hline \multirow{8}{*}{$\begin{array}{l}\text { Nav } \\
\text { ieviesta } \\
\text { IAS } \\
(N=16)\end{array}$} & leṇēmumi (2013, milj. EUR) & 14,47 & 5,85 & 21,98 & 77,7 & 1,8 & 79,5 \\
\hline & Ieṇēmumi (2014, milj. EUR) & 9,43 & 4,20 & 12,13 & 45,8 & 1,6 & 47,4 \\
\hline & leņēmumi (2015, milj. EUR) & 9,64 & 4,55 & 12,51 & 47,7 & 1,5 & 49,2 \\
\hline & leņēmumi (2016, milj. EUR) & 9,15 & 4,65 & 11,83 & 44,7 & 1,4 & 46,1 \\
\hline & Aktīvi (2013, milj. EUR) & 43,70 & 10,10 & 101,75 & 412,0 & 3,3 & 415,3 \\
\hline & Aktīvi (2014, milj. EUR) & 43,83 & 9,65 & 100,73 & 408,6 & 3,4 & 412,0 \\
\hline & Aktīvi (2015, milj. EUR) & 45,59 & 14,35 & 99,31 & 405,6 & 3,1 & 408,7 \\
\hline & Aktīvi (2016, milj. EUR) & 43,29 & 10,90 & 98,12 & 398,8 & 3,0 & 401,8 \\
\hline \multirow{8}{*}{$\begin{array}{l}\text { Ir } \\
\text { ieviesta } \\
\text { IAS } \\
(N=4)\end{array}$} & leṇēmumi (2013, milj. EUR) & 54,10 & 46,25 & 44,23 & 105,9 & 9,0 & 114,9 \\
\hline & leṇēmumi (2014, milj. EUR) & 75,38 & 33,30 & 102,01 & 219,7 & 7,6 & 227,3 \\
\hline & leṇēmumi (2015, milj. EUR) & 48,50 & 31,15 & 36,65 & 75,1 & 28,3 & 103,4 \\
\hline & leṇēmumi (2016, milj. EUR) & 38,85 & 29,75 & 35,38 & 82,7 & 6,6 & 89,3 \\
\hline & Aktīvi (2013, milj. EUR) & 174,63 & 93,45 & 221,02 & 490,2 & 10,7 & 500,9 \\
\hline & Aktīvi (2014, milj. EUR) & 158,15 & 95,20 & 185,87 & 419,0 & 11,6 & 430,6 \\
\hline & Aktīvi (2015, milj. EUR) & 151,63 & 94,80 & 157,20 & 349,9 & 33,5 & 383,4 \\
\hline & Aktīvi (2016, milj. EUR) & 146,70 & 93,50 & 150,45 & 336,4 & 31,7 & 368,1 \\
\hline
\end{tabular}

7. tabula

Pašvaldību ieṇēmumu un aktīvu summu galvenie statistiskie rādītāji (milj. EUR), grupējot atbilstoši tam, vai ir ieviesta vai nav ieviesta IAS (2013-2016); Vidzemes statistiskais reǵions

\begin{tabular}{|c|c|c|c|c|c|c|c|}
\hline & & $\begin{array}{c}\text { Aritmētis- } \\
\text { kais vidējais }\end{array}$ & Mediāna & $\begin{array}{l}\text { Standart- } \\
\text { novirze }\end{array}$ & $\begin{array}{c}\text { Variācijas } \\
\text { amplitūda }\end{array}$ & $\begin{array}{l}\text { Mini- } \\
\text { mums }\end{array}$ & $\begin{array}{l}\text { Maksi- } \\
\text { mums }\end{array}$ \\
\hline \multirow{8}{*}{$\begin{array}{l}\text { Nav } \\
\text { ieviesta } \\
\text { IAS } \\
(N=22)\end{array}$} & leṇēmumi (2013, milj. EUR) & 9,55 & 6,30 & 7,55 & 34,3 & 2,5 & 36,8 \\
\hline & Ieñēmumi (2014, milj. EUR) & 6,72 & 4,65 & 6,07 & 24,1 & 2,1 & 26,2 \\
\hline & Ieṇēmumi (2015, milj. EUR) & 6,81 & 4,70 & 6,30 & 24,6 & 2,1 & 26,7 \\
\hline & Ieṇēmumi (2016, milj. EUR) & 6,43 & 4,10 & 5,75 & 23,9 & 2,1 & 26,0 \\
\hline & Aktīvi (2013, milj. EUR) & 18,35 & 13,25 & 14,80 & 58,3 & 5,0 & 63,3 \\
\hline & Aktīvi (2014, milj. EUR) & 19,09 & 13,85 & 15,71 & 62,0 & 5,0 & 67,0 \\
\hline & Aktīvi (2015, milj. EUR) & 20,87 & 13,45 & 16,95 & 60,2 & 5,5 & 65,7 \\
\hline & Aktīvi (2016, milj. EUR) & 18,17 & 12,25 & 15,14 & 57,0 & 5,0 & 62,0 \\
\hline \multirow{8}{*}{$\begin{array}{l}\text { Ir } \\
\text { ieviesta } \\
\text { IAS } \\
(N=4)\end{array}$} & Ieñēmumi (2013, milj. EUR) & 38,18 & 36,90 & 16,15 & 35,9 & 21,5 & 57,4 \\
\hline & leņēmumi (2014, milj. EUR) & 23,91 & 27,60 & 8,63 & 18,4 & 11,0 & 29,4 \\
\hline & Ieṇēmumi (2015, milj. EUR) & 25,43 & 28,40 & 8,16 & 18,1 & 13,4 & 31,5 \\
\hline & leņēmumi (2016, milj. EUR) & 23,10 & 25,80 & 8,85 & 20,0 & 10,4 & 30,4 \\
\hline & Aktīvi (2013, milj. EUR) & 84,13 & 94,20 & 32,39 & 73,1 & 37,5 & 110,6 \\
\hline & Aktīvi (2014, milj. EUR) & 85,78 & 97,70 & 31,52 & 68,3 & 39,7 & 108,0 \\
\hline & Aktīvi (2015, milj. EUR) & 84,58 & 94,35 & 30,92 & 68,0 & 40,8 & 108,8 \\
\hline & Aktīvi (2016, milj. EUR) & 85,65 & 93,45 & 31,28 & 71,1 & 42,3 & 113,4 \\
\hline
\end{tabular}


4. pielikuma turpinājums

8. tabula

Pašvaldību ieṇēmumu un aktīvu summu galvenie statistiskie rādītāji (milj. EUR), grupējot atbilstoši tam, vai ir ieviesta vai nav ieviesta IAS (2013-2016); Pierīgas statistiskais reǵions

\begin{tabular}{|c|c|c|c|c|c|c|c|}
\hline & & $\begin{array}{c}\text { Aritmētis- } \\
\text { kais vidējais }\end{array}$ & Mediāna & \begin{tabular}{|c} 
Standart- \\
novirze
\end{tabular} & \begin{tabular}{|l} 
Variācijas \\
amplitūda
\end{tabular} & $\begin{array}{l}\text { Mini- } \\
\text { mums }\end{array}$ & $\begin{array}{l}\text { Maksi- } \\
\text { mums }\end{array}$ \\
\hline \multirow{8}{*}{$\begin{array}{l}\text { Nav } \\
\text { ieviesta } \\
\text { IAS } \\
(N=23)\end{array}$} & leṇēmumi (2013, milj. EUR) & 13,96 & 10,30 & 13,06 & 61,9 & 2,3 & 64,2 \\
\hline & leṇēmumi (2014, milj. EUR) & 12,06 & 10,50 & 11,46 & 56,2 & 2,5 & 58,7 \\
\hline & leṇēmumi (2015, milj. EUR) & 12,08 & 9,90 & 9,65 & 44,2 & 2,5 & 46,7 \\
\hline & leṇēmumi (2016, milj. EUR) & 11,84 & 9,60 & 10,52 & 50,6 & 2,5 & 53,1 \\
\hline & Aktīvi (2013, milj. EUR) & 28,83 & 20,90 & 24,47 & 114,1 & 5,4 & 119,5 \\
\hline & Aktīvi (2014, milj. EUR) & 30,86 & 23,30 & 27,51 & 130,6 & 6,1 & 136,7 \\
\hline & Aktīvi (2015, milj. EUR) & 31,67 & 22,20 & 27,26 & 127,8 & 6,8 & 134,6 \\
\hline & Aktīvi (2016, milj. EUR) & 32,42 & 22,60 & 28,08 & 128,5 & 6,5 & 135,0 \\
\hline \multirow{8}{*}{$\begin{array}{l}\text { Ir } \\
\text { ieviesta } \\
\text { IAS } \\
(N=6)\end{array}$} & leṇēmumi (2013, milj. EUR) & 41,60 & 28,10 & 35,58 & 99,0 & 10,3 & 109,3 \\
\hline & leṇēmumi (2014, milj. EUR) & 29,58 & 25,45 & 20,29 & 58,3 & 9,8 & 68,1 \\
\hline & leṇēmumi (2015, milj. EUR) & 32,22 & 25,70 & 21,88 & 62,8 & 10,7 & 73,5 \\
\hline & leṇēmumi (2016, milj. EUR) & 31,92 & 27,40 & 22,86 & 65,0 & 11,0 & 76,0 \\
\hline & Aktīvi (2013, milj. EUR) & 84,00 & 54,25 & 81,33 & 221,1 & 24,7 & 245,8 \\
\hline & Aktīvi (2014, milj. EUR) & 89,03 & 58,10 & 84,47 & 231,3 & 26,2 & 257,5 \\
\hline & Aktīvi (2015, milj. EUR) & 95,13 & 65,55 & 89,62 & 248,1 & 25,7 & 273,8 \\
\hline & Aktīvi (2016, milj. EUR) & 96,47 & 70,85 & 89,86 & 252,2 & 22,5 & 274,7 \\
\hline
\end{tabular}

9. tabula

Pašvaldību ieṇēmumu un aktīvu summu galvenie statistiskie rādītāji (milj. EUR), grupējot atbilstoši tam, vai ir ieviesta vai nav ieviesta IAS (2013-2016); Latgales statistiskais reǵions bez lielajām pilsētām

\begin{tabular}{|c|c|c|c|c|c|c|c|}
\hline & & $\begin{array}{c}\text { Aritmētis- } \\
\text { kais vidējais }\end{array}$ & Mediāna & \begin{tabular}{|c|}
$\begin{array}{c}\text { Standart- } \\
\text { novirze }\end{array}$ \\
\end{tabular} & $\begin{array}{c}\text { Variācijas } \\
\text { amplitūda }\end{array}$ & $\begin{array}{l}\text { Mini- } \\
\text { mums }\end{array}$ & $\begin{array}{l}\text { Maksi- } \\
\text { mums }\end{array}$ \\
\hline \multirow{8}{*}{$\begin{array}{l}\text { Nav } \\
\text { ieviesta } \\
\text { IAS } \\
(N=18)\end{array}$} & leṇēmumi (2013, milj. EUR) & 13,28 & 10,00 & 11,97 & 47,9 & 1,8 & 49,7 \\
\hline & leṇēmumi (2014, milj. EUR) & 9,58 & 6,60 & 7,72 & 29,2 & 1,8 & 31,0 \\
\hline & leṇēmumi (2015, milj. EUR) & 9,19 & 6,85 & 7,60 & 30,1 & 1,7 & 31,8 \\
\hline & len̦ēmumi (2016, milj. EUR) & 8,56 & 5,45 & 8,25 & 34,6 & 1,3 & 35,9 \\
\hline & Aktīvi (2013, milj. EUR) & 24,18 & 17,60 & 19,73 & 59,8 & 3,3 & 63,1 \\
\hline & Aktīvi (2014, milj. EUR) & 25,09 & 18,25 & 20,40 & 65,1 & 3,3 & 68,4 \\
\hline & Aktīvi (2015, milj. EUR) & 25,17 & 18,65 & 20,77 & 69,4 & 3,2 & 72,6 \\
\hline & Aktīvi (2016, milj. EUR) & 24,79 & 17,95 & 20,59 & 69,9 & 3,2 & 73,1 \\
\hline \multirow{8}{*}{$\begin{array}{l}\text { Ir } \\
\text { ieviesta } \\
\text { IAS } \\
(N=1)\end{array}$} & len̦ēmumi (2013, milj. EUR) & 35,70 & & & & & \\
\hline & leṇēmumi (2014, milj. EUR) & 27,90 & & & & & \\
\hline & Ieņēmumi (2015, milj. EUR) & 26,90 & & & & & \\
\hline & leṇēmumi (2016, milj. EUR) & 22,90 & & & & & \\
\hline & Aktīvi (2013, milj. EUR) & 67,90 & & & & & \\
\hline & Aktīvi (2014, milj. EUR) & 77,70 & & & & & \\
\hline & Aktīvi (2015, milj. EUR) & 76,10 & & & & & \\
\hline & Aktīvi (2016, milj. EUR) & 73,30 & & & & & \\
\hline
\end{tabular}


Pašvaldību ieṇēmumu un aktīvu summu galvenie statistiskie rādītāji (milj. EUR), grupējot atbilstoši tam, vai ir ieviesta vai nav ieviesta IAS (2013-2016); Zemgales statistiskais regions bez lielajām pilsētām

\begin{tabular}{|c|c|c|c|c|c|c|c|}
\hline & & $\begin{array}{c}\text { Aritmētis- } \\
\text { kais vidējais }\end{array}$ & Mediāna & $\begin{array}{l}\text { Standart- } \\
\text { novirze }\end{array}$ & $\begin{array}{c}\text { Variācijas } \\
\text { amplitūda }\end{array}$ & $\begin{array}{l}\text { Mini- } \\
\text { mums }\end{array}$ & $\begin{array}{l}\text { Maksi- } \\
\text { mums }\end{array}$ \\
\hline \multirow{8}{*}{$\begin{array}{l}\text { Nav } \\
\text { ieviesta } \\
\text { IAS } \\
(N=18)\end{array}$} & leṇēmumi (2013, milj. EUR) & 11,01 & 8,70 & 7,61 & 26,8 & 4,7 & 31,5 \\
\hline & leņēmumi (2014, milj. EUR) & 8,55 & 6,25 & 6,97 & 27,0 & 2,5 & 29,5 \\
\hline & Ieņēmumi (2015, milj. EUR) & 9,46 & 6,75 & 7,65 & 22,9 & 3,6 & 26,5 \\
\hline & Ieņēmumi (2016, milj. EUR) & 9,43 & 6,25 & 7,42 & 22,3 & 3,8 & 26,1 \\
\hline & Aktīvi (2013, milj. EUR) & 21,49 & 15,50 & 19,59 & 64,7 & 7,2 & 71,9 \\
\hline & Aktīvi (2014, milj. EUR) & 22,58 & 15,60 & 20,69 & 69,4 & 7,3 & 76,7 \\
\hline & Aktīvi (2015, milj. EUR) & 22,17 & 15,45 & 20,51 & 68,4 & 7,0 & 75,4 \\
\hline & Aktīvi (2016, milj. EUR) & 22,32 & 15,40 & 20,63 & 69,6 & 6,6 & 76,2 \\
\hline \multirow{8}{*}{$\begin{array}{l}\text { Ir } \\
\text { ieviesta } \\
\text { IAS } \\
(N=2)\end{array}$} & leņēmumi (2013, milj. EUR) & 21,90 & 21,90 & 15,27 & 21,6 & 11,1 & 32,7 \\
\hline & len̦ēmumi (2014, milj. EUR) & 17,25 & 17,25 & 10,25 & 14,5 & 10,0 & 24,5 \\
\hline & Ieņēmumi (2015, milj. EUR) & 17,30 & 17,30 & 9,48 & 13,4 & 10,6 & 24,0 \\
\hline & Ieņēmumi (2016, milj. EUR) & 17,55 & 17,55 & 9,69 & 13,7 & 10,7 & 24,4 \\
\hline & Aktīvi (2013, milj. EUR) & 46,00 & 46,00 & 40,02 & 56,6 & 17,7 & 74,3 \\
\hline & Aktīvi (2014, milj. EUR) & 48,10 & 48,10 & 43,13 & 61,0 & 17,6 & 78,6 \\
\hline & Aktīvi (2015, milj. EUR) & 48,75 & 48,75 & 42,21 & 59,7 & 18,9 & 78,6 \\
\hline & Aktīvi (2016, milj. EUR) & 49,15 & 49,15 & 42,07 & 59,5 & 19,4 & 78,9 \\
\hline
\end{tabular}

11. tabula

Pašvaldību ieṇēmumu un aktīvu summu galvenie statistiskie rādītāji (milj. EUR), grupējot atbilstoši tam, vai ir ieviesta vai nav ieviesta IAS (2013-2016); Kurzemes statistiskais reġions bez lielajām pilsētām

\begin{tabular}{|c|c|c|c|c|c|c|c|}
\hline & & $\begin{array}{c}\text { Aritmētis- } \\
\text { kais vidējais }\end{array}$ & Mediāna & $\begin{array}{c}\text { Standart- } \\
\text { novirze }\end{array}$ & $\begin{array}{c}\text { Variācijas } \\
\text { amplitūda }\end{array}$ & $\begin{array}{l}\text { Mini- } \\
\text { mums }\end{array}$ & $\begin{array}{l}\text { Maksi- } \\
\text { mums }\end{array}$ \\
\hline \multirow{8}{*}{$\begin{array}{l}\text { Nav } \\
\text { ieviesta } \\
\text { IAS } \\
(\mathrm{N}=15)\end{array}$} & leṇēmumi (2013, milj. EUR) & 10,13 & 5,70 & 13,97 & 56,6 & 1,8 & 58,4 \\
\hline & leṇēmumi (2014, milj. EUR) & 6,90 & 4,20 & 6,91 & 25,3 & 1,6 & 26,9 \\
\hline & leṇēmumi (2015, milj. EUR) & 7,00 & 4,00 & 6,95 & 26,5 & 1,5 & 28,0 \\
\hline & leṇēmumi (2016, milj. EUR) & 6,69 & 4,20 & 6,78 & 26,0 & 1,4 & 27,4 \\
\hline & Aktīvi (2013, milj. EUR) & 18,93 & 9,70 & 23,91 & 95,7 & 3,3 & 99,0 \\
\hline & Aktīvi (2014, milj. EUR) & 19,28 & 9,60 & 23,29 & 91,9 & 3,4 & 95,3 \\
\hline & Aktīvi (2015, milj. EUR) & 21,4 & 11,30 & 22,83 & 91,7 & 3,1 & 94,8 \\
\hline & Aktīvi (2016, milj. EUR) & 19,4 & 9,20 & 22,86 & 90,8 & 3,0 & 93,8 \\
\hline \multirow{8}{*}{$\begin{array}{l}\text { Ir } \\
\text { ieviesta } \\
\text { IAS } \\
(\mathrm{N}=3)\end{array}$} & leṇēmumi (2013, milj. EUR) & 33,8 & 43,60 & 21,67 & 39,9 & 9,0 & 48,9 \\
\hline & leņēmumi (2014, milj. EUR) & 24,7 & 33,10 & 14,84 & 25,9 & 7,6 & 33,5 \\
\hline & Ieṇēmumi (2015, milj. EUR) & 30,2 & 29,40 & 2,40 & 4,6 & 28,3 & 32,9 \\
\hline & leņēmumi (2016, milj. EUR) & 22,0 & 28,40 & 13,43 & 24,5 & 6,6 & 31,1 \\
\hline & Aktīvi (2013, milj. EUR) & 65,9 & 88,60 & 48,02 & 87,6 & 10,7 & 98,3 \\
\hline & Aktīvi (2014, milj. EUR) & 67,3 & 92,30 & 48,35 & 86,5 & 11,6 & 98,1 \\
\hline & Aktīvi (2015, milj. EUR) & 74,4 & 94,70 & 35,39 & 61,4 & 33,5 & 94,9 \\
\hline & Aktīvi (2016, milj. EUR) & 72,9 & 92,30 & 35,70 & 63,0 & 31,7 & 94,7 \\
\hline
\end{tabular}


4. pielikuma turpinājums

12. tabula

Pašvaldību ieṇēmumu un aktīvu summu galvenie statistiskie rādītāji (milj. EUR), grupējot atbilstoši tam, vai ir ieviesta vai nav ieviesta IAS (2013-2016); Vidzemes statistiskais regions bez lielajām pilsētām

\begin{tabular}{|c|c|c|c|c|c|c|c|}
\hline & & $\begin{array}{l}\text { Aritmētis- } \\
\text { kais vidējais }\end{array}$ & Mediāna & $\begin{array}{c}\text { Standart- } \\
\text { novirze }\end{array}$ & $\begin{array}{c}\text { Variācijas } \\
\text { amplitūda }\end{array}$ & $\begin{array}{l}\text { Mini- } \\
\text { mums }\end{array}$ & $\begin{array}{l}\text { Maksi- } \\
\text { mums }\end{array}$ \\
\hline \multirow{8}{*}{$\begin{array}{l}\text { Nav } \\
\text { ieviesta } \\
\text { IAS } \\
(N=22)\end{array}$} & leņēmumi (2013, milj. EUR) & 9,55 & 6,30 & 7,55 & 34,3 & 2,5 & 36,8 \\
\hline & leṇēmumi (2014, milj. EUR) & 6,72 & 4,65 & 6,07 & 24,1 & 2,1 & 26,2 \\
\hline & leņēmumi (2015, milj. EUR) & 6,81 & 4,70 & 6,30 & 24,6 & 2,1 & 26,7 \\
\hline & leṇēmumi (2016, milj. EUR) & 6,43 & 4,10 & 5,75 & 23,9 & 2,1 & 26,0 \\
\hline & Aktīvi (2013, milj. EUR) & 18,35 & 13,25 & 14,80 & 58,3 & 5,0 & 63,3 \\
\hline & Aktīvi (2014, milj. EUR) & 19,09 & 13,85 & 15,71 & 62,0 & 5,0 & 67,0 \\
\hline & Aktīvi (2015, milj. EUR) & 20,87 & 13,45 & 16,95 & 60,2 & 5,5 & 65,7 \\
\hline & Aktīvi (2016, milj. EUR) & 18,17 & 12,25 & 15,14 & 57,0 & 5,0 & 62,0 \\
\hline \multirow{8}{*}{$\begin{array}{l}\text { Ir } \\
\text { ieviesta } \\
\text { IAS } \\
(N=3)\end{array}$} & leņēmumi (2013, milj. EUR) & 31,77 & 28,80 & 12,03 & 23,5 & 21,5 & 45,0 \\
\hline & leņēmumi (2014, milj. EUR) & 22,07 & 27,60 & 9,57 & 16,6 & 11,0 & 27,6 \\
\hline & leņēmumi (2015, milj. EUR) & 23,40 & 28,00 & 8,67 & 15,4 & 13,4 & 28,8 \\
\hline & Ieṇēmumi (2016, milj. EUR) & 20,67 & 24,10 & 9,05 & 17,1 & 10,4 & 27,5 \\
\hline & Aktīvi (2013, milj. EUR) & 75,30 & 88,30 & 33,26 & 62,6 & 37,5 & 100,1 \\
\hline & Aktīvi (2014, milj. EUR) & 78,37 & 91,40 & 34,07 & 64,3 & 39,7 & 104,0 \\
\hline & Aktīvi (2015, milj. EUR) & 76,50 & 85,00 & 32,30 & 62,9 & 40,8 & 103,7 \\
\hline & Aktīvi (2016, milj. EUR) & 76,40 & 84,40 & 30,89 & 60,2 & 42,3 & 102,5 \\
\hline
\end{tabular}

13. tabula

Pašvaldību ieṇēmumu un aktīvu summu galvenie statistiskie rādītāji (milj. EUR), grupējot atbilstoši tam, vai ir ieviesta vai nav ieviesta IAS (2013-2016); Pierīgas statistiskais regions bez lielajām pilsētām

\begin{tabular}{|c|c|c|c|c|c|c|c|}
\hline & & $\begin{array}{c}\text { Aritmētis- } \\
\text { kais vidējais }\end{array}$ & Mediāna & \begin{tabular}{|c|}
$\begin{array}{c}\text { Standart- } \\
\text { novirze }\end{array}$ \\
\end{tabular} & \begin{tabular}{|l} 
Variācijas \\
amplitūda
\end{tabular} & $\begin{array}{l}\text { Mini- } \\
\text { mums }\end{array}$ & $\begin{array}{l}\text { Maksi- } \\
\text { mums }\end{array}$ \\
\hline \multirow{8}{*}{$\begin{array}{l}\text { Nav } \\
\text { ieviesta } \\
\text { IAS } \\
(N=23)\end{array}$} & leṇēmumi (2013, milj. EUR) & 13,96 & 10,30 & 13,06 & 61,9 & 2,3 & 64,2 \\
\hline & leṇēmumi (2014, milj. EUR) & 12,06 & 10,50 & 11,46 & 56,2 & 2,5 & 58,7 \\
\hline & leṇēmumi (2015, milj. EUR) & 12,08 & 9,90 & 9,65 & 44,2 & 2,5 & 46,7 \\
\hline & leṇēmumi (2016, milj. EUR) & 11,84 & 9,60 & 10,52 & 50,6 & 2,5 & 53,1 \\
\hline & Aktīvi (2013, milj. EUR) & 28,83 & 20,90 & 24,47 & 114,1 & 5,4 & 119,5 \\
\hline & Aktīvi (2014, milj. EUR) & 30,86 & 23,30 & 27,51 & 130,6 & 6,1 & 136,7 \\
\hline & Aktīvi (2015, milj. EUR) & 31,67 & 22,20 & 27,26 & 127,8 & 6,8 & 134,6 \\
\hline & Aktīvi (2016, milj. EUR) & 32,42 & 22,60 & 28,08 & 128,5 & 6,5 & 135,0 \\
\hline \multirow{8}{*}{$\begin{array}{l}\text { Ir } \\
\text { ieviesta } \\
\text { IAS } \\
(N=5)\end{array}$} & leñēmumi (2013, milj. EUR) & 28,06 & 26,80 & 14,40 & 39,9 & 10,3 & 50,2 \\
\hline & leñēmumi (2014, milj. EUR) & 21,88 & 25,20 & 8,33 & 21,4 & 9,8 & 31,2 \\
\hline & leṇēmumi (2015, milj. EUR) & 23,96 & 24,30 & 9,32 & 25,7 & 10,7 & 36,4 \\
\hline & leṇēmumi (2016, milj. EUR) & 23,10 & 26,10 & 8,39 & 20,5 & 11,0 & 31,5 \\
\hline & Aktīvi (2013, milj. EUR) & 51,64 & 53,40 & 20,38 & 56,3 & 24,7 & 81,0 \\
\hline & Aktīvi (2014, milj. EUR) & 55,3 & 56,60 & 20,12 & 56,3 & 26,2 & 82,5 \\
\hline & Aktīvi (2015, milj. EUR) & 59,4 & 63,00 & 21,54 & 58,6 & 25,7 & 84,3 \\
\hline & Aktīvi (2016, milj. EUR) & 60,8 & 70,40 & 23,74 & 61,9 & 22,5 & 84,4 \\
\hline
\end{tabular}


5. pielikums

Latvijas pašvaldību sadalījums pēc iedzīvotāju skaita

\begin{tabular}{|c|c|c|c|}
\hline $\begin{array}{l}\text { Nr. } \\
\text { p. k. }\end{array}$ & Novads & $\begin{array}{l}\text { ledzīvotāju skaits } \\
\text { (2016), CSP dati }\end{array}$ & $\begin{array}{c}\text { Sadalijums saskaņā ar MK 30.11.2010. } \\
\text { noteikumiem Nr. } 1075 \text { "Valsts un } \\
\text { pašvaldību institūciju amatu katalogs" }\end{array}$ \\
\hline 1 & Baltinavas novads & 1062 & \multirow{42}{*}{$\begin{array}{c}\text { MAZAS PAŠVALDĪBAS, } \\
\text { kur iedzīvotāju skaits līdz } 5000\end{array}$} \\
\hline 2 & Alsungas novads & 1380 & \\
\hline 3 & Mērsraga novads & 1554 & \\
\hline 4 & Rucavas novads & 1661 & \\
\hline 5 & Naukšēnu novads & 1820 & \\
\hline 6 & Vārkavas novads & 1968 & \\
\hline 7 & Jaunpiebalgas novads & 2209 & \\
\hline 8 & Rugāju novads & 2234 & \\
\hline 9 & Sējas novads & 2242 & \\
\hline 10 & Jaunpils novads & 2347 & \\
\hline 11 & Lubānas novads & 2364 & \\
\hline 12 & Vain,odes novads & 2430 & \\
\hline 13 & Cesvaines novads & 2568 & \\
\hline 14 & Ciblas novads & 2661 & \\
\hline 15 & Pāvilostas novads & 2664 & \\
\hline 16 & Aknīstes novads & 2766 & \\
\hline 17 & Durbes novads & 2776 & \\
\hline 18 & Ërglu novads & 2885 & \\
\hline 19 & Zilupes novads & 3014 & \\
\hline 20 & Mazsalacas novads & 3145 & \\
\hline 21 & Beverīnas novads & 3158 & \\
\hline 22 & Raunas novads & 3172 & \\
\hline 23 & Strenču novads & 3214 & \\
\hline 24 & Varakḷānu novads & 3258 & \\
\hline 25 & Nīcas novads & 3342 & \\
\hline 26 & Tērvetes novads & 3389 & \\
\hline 27 & Līgatnes novads & 3412 & \\
\hline 28 & Skrīveru novads & 3458 & \\
\hline 29 & Mālpils novads & 3474 & \\
\hline 30 & Rundāles novads & 3487 & \\
\hline 31 & Apes novads & 3525 & \\
\hline 32 & Aglonas novads & 3572 & \\
\hline 33 & Salas novads & 3599 & \\
\hline 34 & Neretas novads & 3642 & \\
\hline 35 & Rojas novads & 3749 & \\
\hline 36 & Viesītes novads & 3802 & \\
\hline 37 & Pārgaujas novads & 3827 & \\
\hline 38 & Vecpiebalgas novads & 3861 & \\
\hline 39 & Dundagas novads & 3971 & \\
\hline 40 & Jēkabpils novads & 4682 & \\
\hline 41 & Alojas novads & 4868 & \\
\hline 42 & Skrundas novads & 4919 & \\
\hline
\end{tabular}


5. pielikuma turpinājums

\begin{tabular}{|c|c|c|c|}
\hline $\begin{array}{l}\text { Nr. } \\
\text { p. k. }\end{array}$ & Novads & $\begin{array}{l}\text { ledzīvotāju skaits } \\
\text { (2016), CSP dati }\end{array}$ & $\begin{array}{c}\text { Sadalijjums saskaṇā ar MK 30.11.2010. } \\
\text { noteikumiem Nr. } 1075 \text { "Valsts un } \\
\text { pašvaldību institūciju amatu katalogs" }\end{array}$ \\
\hline 1 & Viḷakas novads & 5007 & \multirow{42}{*}{$\begin{array}{l}\text { VIDĒJI LIELAS PAŠVALDĪBAS, } \\
\text { kur iedzīvotāju skaits ir } \\
\text { no } 5000 \text { līdz } 20000\end{array}$} \\
\hline 2 & Riebinu novads & 5092 & \\
\hline 3 & Krimuldas novads & 5134 & \\
\hline 4 & Rūjienas novads & 5151 & \\
\hline 5 & Kokneses novads & 5202 & \\
\hline 6 & Plavininu novads & 5278 & \\
\hline 7 & Amatas novads & 5370 & \\
\hline 8 & Priekules novads & 5412 & \\
\hline 9 & Baldones novads & 5434 & \\
\hline 10 & K̦eguma novads & 5466 & \\
\hline 11 & Jaunjelgavas novads & 5508 & \\
\hline 12 & Kārsavas novads & 5667 & \\
\hline 13 & Brocēnu novads & 5687 & \\
\hline 14 & Saulkrastu novads & 5752 & \\
\hline 15 & Krustpils novads & 5834 & \\
\hline 16 & Viḷānu novads & 5895 & \\
\hline 17 & Kocēnu novads & 6090 & \\
\hline 18 & Auces novads & 6595 & \\
\hline 19 & Ropažu novads & 6687 & \\
\hline 20 & Carnikavas novads & 6975 & \\
\hline 21 & Ilūkstes novads & 7206 & \\
\hline 22 & Engures novads & 7232 & \\
\hline 23 & Dagdas novads & 7444 & \\
\hline 24 & Inčukalna novads & 7715 & \\
\hline 25 & Salacgrīvas novads & 7818 & \\
\hline 26 & Priekulu novads & 7965 & \\
\hline 27 & Burtnieku novads & 8059 & \\
\hline 28 & Garkalnes novads & 8102 & \\
\hline 29 & Vecumnieku novads & 8263 & \\
\hline 30 & Valkas novads & 8267 & \\
\hline 31 & Kandavas novads & 8332 & \\
\hline 32 & Aizkraukles novads & 8406 & \\
\hline 33 & lecavas novads & 8599 & \\
\hline 34 & Aizputes novads & 8658 & \\
\hline 35 & Grobinas novads & 8745 & \\
\hline 36 & Ikšksiles novads & 9451 & \\
\hline 37 & Ozolnieku novads & 9721 & \\
\hline 38 & Preilu novads & 9754 & \\
\hline 39 & Babītes novads & 9954 & \\
\hline 40 & Lielvārdes novads & 9993 & \\
\hline 41 & Stopinu novads & 10366 & \\
\hline 42 & Ādažu novads & 10618 & \\
\hline
\end{tabular}


5. pielikuma turpinājums

\begin{tabular}{|c|c|c|c|}
\hline $\begin{array}{l}\text { Nr. } \\
\text { p. } k \text {. }\end{array}$ & Novads & $\begin{array}{l}\text { ledzīvotāju skaits } \\
\text { (2016), CSP dati }\end{array}$ & $\begin{array}{c}\text { Sadalījums saskaṇā ar MK 30.11.2010. } \\
\text { noteikumiem Nr. 1075 “Valsts un } \\
\text { pašvaldību institūciju amatu katalogs” }\end{array}$ \\
\hline 43 & Līvānu novads & 11424 & \multirow{12}{*}{$\begin{array}{l}\text { VIDĒJ LIELAS PAŠVALDĪBAS, } \\
\text { kur iedzīvotāju skaits ir } \\
\text { no } 5000 \text { līdz } 20000\end{array}$} \\
\hline 44 & Ventspils novads & 11452 & \\
\hline 45 & Smiltenes novads & 12473 & \\
\hline 46 & Balvu novads & 12687 & \\
\hline 47 & Ludzas novads & 12941 & \\
\hline 48 & Alūksnes novads & 15352 & \\
\hline 49 & Krāslavas novads & 15423 & \\
\hline 50 & Cēsu novads & 16757 & \\
\hline 51 & Limbažu novads & 16869 & \\
\hline 52 & Siguldas novads & 17341 & \\
\hline 53 & Mārupes novads & 18835 & \\
\hline 54 & Olaines novads & 19769 & \\
\hline $\begin{array}{l}\text { Nr. } \\
\text { p. k. }\end{array}$ & Novads & $\begin{array}{l}\text { ledzīvotāju skaits } \\
\text { (2016), CSP dati }\end{array}$ & $\begin{array}{c}\text { Sadalījums saskaṇā ar MK 30.11.2010. } \\
\text { noteikumiem Nr. 1075 “Valsts un } \\
\text { pašvaldību institūciju amatu katalogs” }\end{array}$ \\
\hline 1 & Dobeles novads & 20498 & \multirow{22}{*}{$\begin{array}{l}\text { LIELAS PAŠVALDĪBAS, } \\
\text { kurā iedzīvotāju skaits ir } \\
\text { no } 20000 \text { līdz } 500000\end{array}$} \\
\hline 2 & Gulbenes novads & 21223 & \\
\hline 3 & Daugavpils novads & 22194 & \\
\hline 4 & Salaspils novads & 22384 & \\
\hline 5 & Jēkabpils & 22722 & \\
\hline 6 & Kekavas novads & 22942 & \\
\hline 7 & Jelgavas novads & 22948 & \\
\hline 8 & Valmiera & 23230 & \\
\hline 9 & Madonas novads & 23444 & \\
\hline 10 & Kuldīgas novads & 23492 & \\
\hline 11 & Saldus novads & 23645 & \\
\hline 12 & Bauskas novads & 23891 & \\
\hline 13 & Rēzeknes novads & 26707 & \\
\hline 14 & Tukuma novads & 28726 & \\
\hline 15 & Rēzekne & 28745 & \\
\hline 16 & Talsu novads & 28947 & \\
\hline 17 & Ogres novads & 34028 & \\
\hline 18 & Ventspils & 35914 & \\
\hline 19 & Jūrmala & 49305 & \\
\hline 20 & Jelgava & 57045 & \\
\hline 21 & Liepāja & 70499 & \\
\hline 22 & Daugavpils & 85286 & \\
\hline 23 & Rīga & 638784 & $\begin{array}{l}\text { L̦OTI LIELA PAŠVALDĪBA, kurā iedzīvotāju } \\
\text { skaits pārsniedz } 500000\end{array}$ \\
\hline
\end{tabular}




\section{SUMMARY}

On the basis of fundamental and applied research on the role and implementation of internal audit, the author evaluated the internal audit in direct state administration of Latvia and local governments in Latvia. Within the framework of the monograph, an internal audit of the direct state administration and local governments was carried out, using three auditor and expert surveys, an internal audit implementation model in the local governments of Latvia was developed, an evaluation approach to local government's internal audit and a list of added value or benefit of the internal audit was drafted.

The first chapter of the monograph is devoted to the object and subject of the research, characterising the internal audit and its function on the international level and in the context of European countries. In order to evaluate the role of internal audit in Latvian state administration and local governments, the second chapter describes the system of Latvian state administration and local government. An analysis of empirical research results has been performed to evaluate development of internal audit. The third chapter of the monograph includes the possibilities for improvement of internal audit of the Latvian state direct administration and local governments. The author develops a model of internal audit implementation in the local governments of Latvia, an approach to assessment of internal audits of local governments, and internal audits' added values or a list of benefits for the local governments.

Questions related to the topic and methodology of the research were published in 8 scientific publications and reported at 8 annual conferences of the University of Latvia, as well as in 11 international scientific conferences in 3 countries. 


\section{ANALYSIS OF INTERNAL AUDIT ON THE INTERNATIONAL SCALE}

Based on the scientific research and analysis of the literature on economics and historical economic events worldwide, the author divides the current thesis dedicated to promotion of the development of internal audit (IA) into three important phases, which, in turn, are divided into several successive periods or stages:

1) the prime origin of internal audit (4000 B.C. to 1940), which includes the events affecting the IA development and the related events worldwide before the foundation of the Institute of Internal Auditors (IIA);

2) the characteristics of global internal audit, the foundation of the IIA and its historical development (1941-1999);

3) The IT period (since 2000), when the virtual environment and communication in e-environment becomes crucial for management processes, including quality of the functions of internal audit, which depends upon the IT. During this period, with the enlargement of EU one of the mandatory requirements for new candidate states is to enter the process of the system of IA.

Given the fact that the IIA was established in the USA in 1941, the economic and financial events taking place directly in the USA had a significant effect on the IA development, concerning significant amendments to laws (Sarbanes Oxley Act), and the formation of other professional organizations, for example, IIAPF, COSO, and global IT progress at the beginning of the $21^{\text {st }}$ century.

Pursuant to the IA analysis, the author concludes that historically the IA practitioners and scientists who created the first significant publications on the IA can be regarded as the founders of the IA profession. In the author's opinion, A. Collins, C. A. Schmidt, the founders of the IIA in the USA made a great contribution to development of this sphere.

A significant part of the global studies and the latest European research of the IA is assigned to measuring the IA efficiency and to analysis of the IA added value. The most important IA valuation factors from the viewpoint of researchers worldwide is the use and adherence to International Standards for the Professional Practice of Internal Auditing for the IA processes, a significant role of the IA Committee in the IA process of an institution, efficient organization of cooperation in the sphere of internal and external audit, inclusion of the public sector's IA activities in regulatory enactments, as evidenced by many studies (see Table 1). 
Table 1. Groups of scientific and practical literature on internal auditing (the $2^{\text {th }}$ century-2018)

\begin{tabular}{|c|c|c|}
\hline $\begin{array}{l}\text { Internal audit } \\
\text { process }\end{array}$ & Authors, year & Main research questions \\
\hline $\begin{array}{l}\text { Internal audit } \\
\text { methodology }\end{array}$ & \begin{tabular}{|l|} 
EC Compendium $(2012,2014)$, \\
Chambers A. D. $(2015,2016)$, \\
IIARF researches $(2006,2010,2015)$, \\
Niekwlands H. (2006), \\
Public Sector Internal Audit \\
Standards (2013)
\end{tabular} & $\begin{array}{l}\text { The standards for the professional practice } \\
\text { of internal auditing, definition, internal audit } \\
\text { performance methods, approaches, work } \\
\text { documents, analysis of examples. } \\
\text { Research that demonstrates the role of internal } \\
\text { audit function in normative acts in the US, UK } \\
\text { and Australia. }\end{array}$ \\
\hline $\begin{array}{l}\text { Added value of } \\
\text { internal audit }\end{array}$ & $\begin{array}{l}\text { Diamond J. (2002), Piper A. (2015), } \\
\text { Ray E. (2009), } \\
\text { Rose J. (2013), } \\
\text { Global Report, IIA (2014), } \\
\text { Abdolmohammadi M. et al., } \\
\text { IAIPF (2016), } \\
\text { Sarens G., Lamboglia R. (2013), } \\
\text { Soh D. S. B., } \\
\text { Martinov-Bennie N. (2011) }\end{array}$ & $\begin{array}{l}\text { Role of internal audit in public administration } \\
\text { Role of internal audit in the structure of the } \\
\text { institution. } \\
\text { Role, responsibility, effectiveness, evaluation } \\
\text { of internal audit - deviation between role and } \\
\text { assessment. } \\
\text { Maturity model - confidence and advice on } \\
\text { how the change of IA direction affects the } \\
\text { institution's added value, analysis of the CBOK } \\
\text { global internal auditors' surveys in } 2015 \text { - risk } \\
\text { management, audit procedures, and others. } \\
\text { Internal auditor's compliance with standards. }\end{array}$ \\
\hline $\begin{array}{l}\text { Role of audit } \\
\text { committee } \\
\text { in successful } \\
\text { functioning of } \\
\text { internal audit }\end{array}$ & \begin{tabular}{|l|} 
Davies M. (2009), IARF White paper \\
(2013), Zaman M., Sarens G. (2013), \\
KPMG (2013), IIAFR researches \\
(2010, 2015), Public Internal Control \\
in the EU (2014)
\end{tabular} & $\begin{array}{l}\text { Effective cooperation between internal audit } \\
\text { and audit committee in local governments in } \\
\text { Wales and Great Britain, informal cooperation } \\
\text { between manager of internal audit unit and } \\
\text { audit committee, role of audit committee in } \\
\text { internal audit evaluation. }\end{array}$ \\
\hline $\begin{array}{l}\text { Evaluation of } \\
\text { internal audit }\end{array}$ & $\begin{array}{l}\text { Dubis G. S., Jain P., Manchanda A., } \\
\text { Thakkar R. (2010), } \\
\text { KPMG (2003), } \\
\text { Marks N. (2018), } \\
\text { IAIPF CBOK (2010, 2015), } \\
\text { Chen J.-F., Lin W.-Y. (2011) }\end{array}$ & $\begin{array}{l}\text { Assessment of internal audit's effectiveness } \\
\text { and suitableness, different examples of } \\
\text { questionnaire. } \\
\text { Questionnaires for IA evaluation: IA } \\
\text { Committee's assessment, the external audit's } \\
\text { assessment, the management's assessment, as } \\
\text { well as the IA self-assessment, assessments of } \\
\text { IA effectiveness. }\end{array}$ \\
\hline $\begin{array}{l}\text { Effectiveness and } \\
\text { philosophy of } \\
\text { internal audit }\end{array}$ & $\begin{array}{l}\text { Lenz R., Hahn U. (2015) } \\
\text { Parker G. W. (1995.), MacRae E. } \\
\text { (2014) } \\
\text { Norman C. S. et al. (2009) } \\
\text { Sawyer L. B. (1995) } \\
\text { Ramamoorti S., Siegfried A. N., } \\
\text { IAIPF (2016) } \\
\text { Harrington L., Piper A., IAIPF (2016) } \\
\text { Coetzee P. et al. (2015) }\end{array}$ & $\begin{array}{l}\text { Empirical studies for determining the } \\
\text { effectiveness of internal audit in academic } \\
\text { literature. } \\
\text { Analysis of IA and fraud risk as essential } \\
\text { elements of IA profession, analysis of IA } \\
\text { mission, strategy, audit culture worldwide, } \\
\text { IA and risk management, the role of audit } \\
\text { committees, the role of standards in IA } \\
\text { processes, education of internal auditors. } \\
\text { Characteristics of the IA profession, critical } \\
\text { analysis of the IAIPF research based on the data } \\
\text { of South-Africa. }\end{array}$ \\
\hline
\end{tabular}


Table 1 continued

\begin{tabular}{|c|c|c|}
\hline $\begin{array}{l}\text { Internal audit } \\
\text { process }\end{array}$ & Authors, year & Main research questions \\
\hline $\begin{array}{l}\text { Internal audit } \\
\text { definition }\end{array}$ & $\begin{array}{l}\text { Academic Terminology Database, } \\
\text { Skujina V. (2010), Economic terms } \\
\text { Dictionary (1997), Economic } \\
\text { and Finance Dictionary (2003), } \\
\text { Economic Glossary (2000), } \\
\text { The Institute of Internal Auditors } \\
\text { 1999, 2008, Malderis G. (2008), } \\
\text { Sulca R. (2010), } \\
\text { LR normative acts }\end{array}$ & $\begin{array}{l}\text { Changes in the definition of internal audit } \\
\text { and differences between standards and the } \\
\text { definitions contained in economic literature. }\end{array}$ \\
\hline $\begin{array}{l}\text { Internal audit } \\
\text { development in } \\
\text { Latvia }\end{array}$ & $\begin{array}{l}\text { Blazevica I. (2000), } \\
\text { Gruba I. (2010), } \\
\text { Sulca R. (2010), } \\
\text { Verdina G. (2012), } \\
\text { Bruna I. (2010, 2014), } \\
\text { Faitusa I. (from 2010), } \\
\text { Ivanova I. (2014, 2016), } \\
\text { Ministry of Finance }\end{array}$ & $\begin{array}{l}\text { Control self-assessment - one of internal audit } \\
\text { methods. } \\
\text { Internal audit as an outsourced service - pluses } \\
\text { and minuses. } \\
\text { Development of internal audit in local } \\
\text { governments. } \\
\text { Internal control aspects including internal } \\
\text { auditing. } \\
\text { Internal audit in the Baltic states. } \\
\text { Possibilities of internal audit of state } \\
\text { administration and local governments in Latvia, } \\
\text { comparison to EU countries. } \\
\text { Internal audit approaches, research of IIARF, } \\
\text { interviews with professionals. } \\
\text { Annual analytical reports about internal audit } \\
\text { function in state administration of Latvia. }\end{array}$ \\
\hline $\begin{array}{l}\text { Cooperation of } \\
\text { internal audit and } \\
\text { external audit }\end{array}$ & $\begin{array}{l}\text { Diamond J. (2002), } \\
\text { IIAFR researches }(2006,2010,2015), \\
\text { EC Compendium }(2012,2014), \\
\text { The State Audit Office of the } \\
\text { Republic of Latvia (2014), } \\
\text { Sudraba I. (2012), } \\
\text { ECIIA Guidelines (2010), } \\
\text { Zammit S., Baldacchino P. (2012), } \\
\text { ECIIA (2013) } \\
\text { Chartered Institute of Internal } \\
\text { Auditors (2017) }\end{array}$ & $\begin{array}{l}\text { Recommendations for internal and external } \\
\text { audit cooperation. } \\
\text { Comparison of the views of IA professionals in } \\
\text { different years in various countries worldwide } \\
\text { with several thousands of respondents. } \\
\text { Malta's example of IA and external audit } \\
\text { cooperation through informal communication. } \\
\text { Improvement of the internal and external } \\
\text { audit cooperation through the COSO Risk } \\
\text { Management Framework. } \\
\text { Difference in roles of internal audit and external } \\
\text { audit. }\end{array}$ \\
\hline
\end{tabular}

Source: Table by author

The author analyses the factors of the choice in all the EU Member States that joined EU in 2004, and in Great Britain, which is one of the oldest Member States and historically among the first states to introduce the IA, as evidenced by numerous publications. Each of the European countries included in the analysis has its own background and different experience regarding IA functions with respect to added value, which other countries can acquire. On the basis of the 
completed research, the author brings forward several examples of positive IA experience of the state administration adopted by other EU Member States, which can be used for development of IA at the state administration of Latvia:

1) Experience of Estonia - stipulating implementation of the IA system in municipalities by law;

2) The state administration experience of Lithuania and Hungary - establishing the register of auditors, certification on the basis of implementing a certification programme for internal auditors with training modules, involving university professors and practitioners;

3) The state administration experience of Poland - establishing the audit committees in each ministry of direct state administration;

4) The state administration experience of Malta - tackling the obstacles to the IA and external audit cooperation, cooperation stipulated in legislation to ensure better communication, sufficient resources, the use of counselling activities;

5) The state administration experience of Cyprus - defining various specialisations and qualifications of internal auditors that include engineers from different sectors, professional accountants, who hold the membership of the national and international institutes;

6) The state administration experience of Great Britain - organisation of cooperation between internal and external audit, sharing of the audit strategies, plans, reducing the burden of audit on the organization.

The author recommends that the European Commission's institutions responsible for the IA would draw up guidelines for preparation of regular reports on public administration and local government IAS, including quantitative data on the IA in the report that would be comparable in all the EU Member-States, such as staff qualification (length of service, number of certified internal auditors), IA process efficiency (number of completed internal audits, implementation of the annual plan in \%, adherence to time-limits for submission of audit reports), added value of the internal audit of structural units (the proportion of introduced recommendations, the proportion of auditors' days, evaluation of the IAS manager, the result of external valuation, evaluation of the IA board, etc.). 


\section{EVALUATION OF DEVELOPMENT OF STATE ADMINISTRATION OF LATVIA INTERNAL AUDIT SYSTEM}

In the author's opinion, development of internal audit methodology in the direct state administration of Latvia in accordance with the amendments of laws and regulations is divided into four stages:

1) Introduction of internal audit in the direct State Administration of Latvia (1999-2002);

2) Transition period - change of status - compliance with the EU requirements (2003-2009);

3) Inclusion of the requirements stipulated by international standards in laws and regulations (2010-2012);

4) Improvement of the internal audit system, legal regulation (from 2013).

Since 2013 - improvement of the internal audit system, legal regulation - in order to ensure more extensive and proficient auditors' knowledge and more competent auditors, it is determined by the law that for performance of his or her duties, the IAS manager requires a certificate of state administration's internal auditor obtained in the order established in regulatory enactments or the certificate attesting to internal auditor's professional qualification recognized by the Association "Institute of Internal Auditors".

Regulatory enactments as amended lay down possible action for the supervision and monitoring the performance at all stages of the internal audit, in the event if a single internal auditor performs the internal audit function in the ministry or the institution. In such a case, internal audit performance monitoring and quality monitoring can be done by other internal audit unit institutions. Similarly, with the changes in internal audit unit activities according to the determined scope of work, internal audit unit provides an opinion on the internal control systems: risk management measures, control measures, management measures.

Table 3 summarises the number of municipalities in statistical regions of Latvia that have or have not implemented the IAS for 2016. IAS are most commonly used in the municipalities of Pieriga statistical region (6 municipalities out of 29 municipalities or $20.7 \%$ of municipalities), while they have been used the least in the municipalities of Latgale statistical region (14.3\% in 3 municipalities out of 21 municipalities). In Kurzeme $-20 \%$ of all the municipalities in the statistical region, in Zemgale - 18.2\%, while in Vidzeme $15.4 \%$ of all the statistical region's municipalities have implemented the IAS.

The results of the statistical analysis for the period from 2013 to 2016 show that the amount of revenues of municipalities of Latvia with IAS and municipalities without IAS and local governments' assets considerably varies. When analysing 
the statistical regions of Latvia, the author concludes that a coherence is observed: the average amounts of revenues and assets of the municipalities that have not introduced IAS are smaller than in the municipalities operating IAS. The average revenues in the municipalities where the IAS was implemented within the period from 2013 to 2016 were approximately by EUR 29.42 million higher and on average the total amount of assets was by $76 \%$ higher than in municipalities without the IAS, which confirms the proposed hypothesis that large municipalities (with higher revenues and assets) have introduced IAS.

Table 3. Number of local governments in Latvia with and without IAS, 2013-2016

\begin{tabular}{|l|c|c|c|}
\hline \multicolumn{1}{|c|}{ Groupings } & $\begin{array}{c}\text { With } \\
\text { internal } \\
\text { audit }\end{array}$ & $\begin{array}{c}\text { Without } \\
\text { internal } \\
\text { audit }\end{array}$ & $\begin{array}{c}\text { Total number } \\
\text { of local } \\
\text { governments }\end{array}$ \\
\hline Total local governments in Latvia & 22 & 97 & 119 \\
\hline Local governments in Latgale statistical region & 3 & 18 & 21 \\
\hline Local governments in Zemgale statistical region & 4 & 18 & 22 \\
\hline Local governments in Kurzeme statistical region & 4 & 16 & 20 \\
\hline Local governments in Vidzeme statistical region & 4 & 22 & 26 \\
\hline Local governments in Pierīga statistical region & 6 & 23 & 29 \\
\hline Local governments, except large towns & 14 & 96 & 110 \\
\hline $\begin{array}{l}\text { Local governments in Latgale statistical region, except large towns - } \\
\text { Rēzekne, Daugavpils }\end{array}$ & 1 & 18 & 19 \\
\hline $\begin{array}{l}\text { Local governments in Zemgale statistical region, except large } \\
\text { towns - Jelgava, Jēkabpils }\end{array}$ & 2 & 18 & 20 \\
\hline $\begin{array}{l}\text { Local governments in Kurzeme statistical region, except large } \\
\text { towns - Liepaja, Ventspils }\end{array}$ & 3 & 15 & 18 \\
\hline $\begin{array}{l}\text { Local governments in Vidzeme statistical region, except large } \\
\text { towns - Valmiera }\end{array}$ & 3 & 22 & 25 \\
\hline $\begin{array}{l}\text { Local governments in Pierīga statistical region, except large towns - } \\
\text { Jūrmala }\end{array}$ & 5 & 23 & 28 \\
\hline
\end{tabular}

Source: Table by author, data from author's research

Since the size of the population is the factor affecting the total income or budget of municipalities, the author presents a possible solution for implementation of local government internal audit by allocating municipalities according to population criterion in Section 3 of the monograph. 


\section{OPPORTUNITIES FOR IMPROVEMENT OF INTERNAL AUDIT SYSTEM OF DIRECT STATE ADMINISTRATION AND LOCAL GOVERNMENTS OF LATVIA}

The author proposes two options to establish the local government IA system:

Option 1. The IA structural unit to be instituted in large and very large municipalities (size of the population exceeds 20 000, pursuant to Cabinet Regulation No. 1075 "Job Catalogue of State and Local Government Institutions" of November 30, 2010, see Annex 10). Internal audits are planned annually, and internal auditors on the annual basis produce a report for the responsible ministry (Ministry of Finance, MF) on the IA activity in the municipality. Other municipalities must ensure that the IA would be carried out within 3-5 years, subject to the priority, embracing all the systems of local governments. Work can be arranged involving outsourced specialists or by recruiting an internal auditor for a certain period.

Option 2. Following the municipal reform, which is currently being established by the Ministry of Environmental Protection and Regional Development (MEPRD), aiming at the increase of economic development potential of the territories and cooperation between local governments in the provision of public services, implementation at the territories of 29 districts or the territories of cooperation of local government for the implementation of the IAS in all 29 areas of municipal cooperation or district centres. 29 territories of cooperation - 21 development centres of regional significance and 9 republican cities (Jūrmala near Riga). Planning of IA in large municipalities would be continuous, but in the small and medium-scale municipalities (up to 20000 inhabitants) - periodic, which can be practically implemented, as follows: in large municipalities, the systems are audited at least every 3-5 years, subject to the priority, while in small ones - the general internal audit, embracing all systems of local governments would be carried out at least once every five years.

The author deems that the IAS would be at the centre of the districts and that auditors would operate in all the municipalities within that area, for example, the city of Rēzekne, Rēzekne province, Viḷāni province is a part of Rēzekne district. The use of the services of internal auditors is possible, as follows: contracts are concluded with each local government separately, or a single contract with the district management, if it is formed after the implementation of the reform.

Having summarised the information, the author developed a proposal: the establishment of the IAS and the key principles of operation must be included in the relevant laws and the Cabinet regulations, with clear-cut, internal audit reporting procedures for the management, and the functions of the audit 


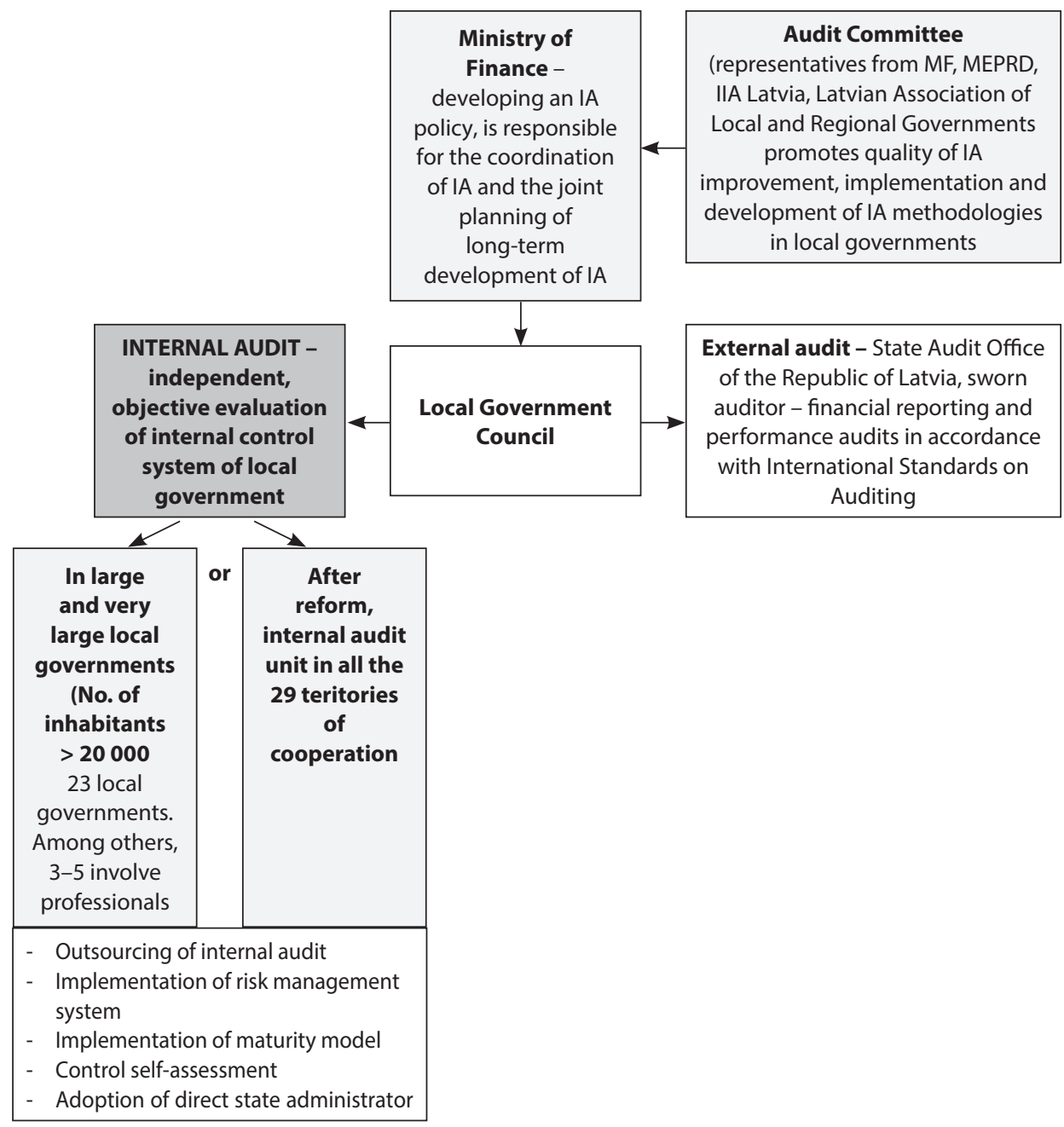

Figure 1. Introduction of internal audit model in local governments

Source: Figure by author on the basis of literature analysis and regulatory enactments of Latvia

committee defined through the IA structure. Similarly, it should be stated that the IA annual reports of all the local governments "On the IA results of local government during the current year" are publicly available.

The author has developed the application of the IA function and an alternative approach to the direct local government (see Fig. 1). To characterize the key tasks of each unit, the author has used the Republic of Latvia regulatory enactments applicable to the IA system of the direct state administration, IIA model offered by the IAS (Institute of Internal Auditors, 2013), International 
Standards for the Professional Practice of Internal Auditing (IIA, 2017). The model assumes that the IA is implemented by one of the alternatives, taking over the methodology of the state direct administration or working on the alternatives to the solutions tested in the worldwide internal audit practice.

The model provided in Fig. 1 depicts a possible implementation model of the IA, proposing the main tasks of each institution regarding introduction, implementation, evaluation and monitoring of the IA, using the framework of regulatory enactments of the state direct administration, yet adapting it to the system of local governments of Latvia.

The author offers to apply the proposed approach in carrying out external evaluations to the commission of the responsible ministry in the sector, the representatives of the audit committee, to the management of the municipality and to the auditees by inviting independent experts in the field of internal audit, when evaluating the efficiency of the local internal audit unit, compliance with legal enactments regulating internal audit, standards of professional practice, and the best practice in auditing.

To carry out an assessment, an auditor of the local government's internal audit completes Table 3, according to the results of document checks, interviews with internal auditors, the management of internal audit unit, and the leadership of local government, evaluating the twelve factors in the column "Rating" and assigning appropriate scores: 2,1 , or 0 .

Table 3. Valuation approach of internal audit in local governments

\begin{tabular}{|c|c|c|c|c|}
\hline $\begin{array}{l}\text { Basic } \\
\text { element* }\end{array}$ & Factor** & $\begin{array}{c}\text { Checked, evaluated } \\
\text { document }\end{array}$ & Rating ${ }^{* * * *}$ & Notes \\
\hline $\begin{array}{l}1 . \\
\text { Organisational } \\
\text { independence }\end{array}$ & $\begin{array}{l}\text { 1.1. Correct } \\
\text { introduction } \\
\text { and } \\
\text { subordination } \\
\text { of internal } \\
\text { audit in the } \\
\text { organisational } \\
\text { structure }\end{array}$ & $\begin{array}{l}\text { Organisational structural } \\
\text { scheme, instructions, bylaws }\end{array}$ & $\begin{array}{l}2 \text { - complies with the internal } \\
\text { audit standards and best } \\
\text { practice requirements; } \\
1 \text { - partially complies with the } \\
\text { internal audit standards and } \\
\text { best practice requirements; } \\
0 \text { - does not comply with the } \\
\text { internal audit standards and } \\
\text { best practice requirements. }\end{array}$ & \\
\hline $\begin{array}{l}\text { 2. Competent } \\
\text { management }\end{array}$ & $\begin{array}{l}\text { 2.1. Exploring } \\
\text { and assessing } \\
\text { the needs } \\
\text { of local } \\
\text { government's } \\
\text { management }\end{array}$ & $\begin{array}{l}\text { Minutes of proceedings } \\
\text { Audit plans }\end{array}$ & $\begin{array}{l}2 \text { - needs were explored; } \\
1 \text { - actions carried out } \\
\text { partially; } \\
0 \text { - needs were not explored. }\end{array}$ & \\
\hline
\end{tabular}


Table 3 continued

\begin{tabular}{|c|c|c|c|c|}
\hline $\begin{array}{c}\text { Basic } \\
\text { element* }\end{array}$ & Factor** & $\begin{array}{c}\text { Checked, evaluated } \\
\text { document }\end{array}$ & Rating ${ }^{* * * *}$ & Notes \\
\hline & $\begin{array}{l}\text { 2.2. Advising } \\
\text { the local } \\
\text { government's } \\
\text { management } \\
\text { and audit } \\
\text { committee }\end{array}$ & $\begin{array}{l}\text { Minutes of proceedings, } \\
\text { reports, which: } \\
\text { 1) provide information on } \\
\text { risks; } \\
\text { 2) provide an opinion on the } \\
\text { operation of the system as } \\
\text { a whole; } \\
\text { 3) provide optimization of } \\
\text { costs, eliminates controls } \\
\text { and activities that do not } \\
\text { add value; } \\
\text { 4) advise on the issues to be } \\
\text { addressed regularly; } \\
\text { 5) provide an overview of } \\
\text { the control environment, } \\
\text { report the necessary } \\
\text { improvements. }\end{array}$ & $\begin{array}{l}2 \text { - four to five conditions are } \\
\text { met; } \\
1 \text { - two to three conditions } \\
\text { are met; } \\
0 \text { - one condition is met. }\end{array}$ & \\
\hline & $\begin{array}{l}2.3 . \\
\text { Management } \\
\text { proficiency of } \\
\text { internal audit } \\
\text { unit }\end{array}$ & $\begin{array}{l}\text { The head of the local } \\
\text { government's internal audit } \\
\text { unit has an appropriate } \\
\text { level of education and a } \\
\text { professional certificate in the } \\
\text { field of internal audit. }\end{array}$ & $\begin{array}{l}2 \text { - complies; } \\
1 \text { - partially complies; } \\
0 \text { - does not comply. }\end{array}$ & \\
\hline $\begin{array}{l}\text { 3. Official } \\
\text { mandate }\end{array}$ & $\begin{array}{l}\text { 3.1. Internal } \\
\text { audit facilitates } \\
\text { achievement } \\
\text { of corporate } \\
\text { targets }\end{array}$ & $\begin{array}{l}\text { Contribution of the internal } \\
\text { audit to the preparation of the } \\
\text { municipal annual report. } \\
\text { Consultations, minutes of } \\
\text { interviews, IA working papers, } \\
\text { internal audit report. }\end{array}$ & $\begin{array}{l}2 \text { - complies; } \\
1 \text { - partially complies; } \\
0 \text { - does not comply. }\end{array}$ & \\
\hline \multirow{2}{*}{$\begin{array}{l}\text { 4. Unlimited } \\
\text { access to } \\
\text { information } \\
\text { and resources }\end{array}$} & $\begin{array}{l}\text { 4.1. Use of data } \\
\text { analytics for } \\
\text { internal audit }\end{array}$ & $\begin{array}{l}\text { Internal audit documents, } \\
\text { internal audit reports. }\end{array}$ & $\begin{array}{l}2 \text { - complies; } \\
1 \text { - partially complies; } \\
0 \text { - does not comply. }\end{array}$ & \\
\hline & $\begin{array}{l}\text { 4.2. Identifying } \\
\text { IT risks in } \\
\text { internal audit } \\
\text { plans }\end{array}$ & $\begin{array}{l}\text { IT systems included in the } \\
\text { internal audit plans. }\end{array}$ & $\begin{array}{l}2 \text { - complies; } \\
1 \text { - partially complies; } \\
0 \text { - does not comply. }\end{array}$ & \\
\hline $\begin{array}{l}\text { 5. Unbiased } \\
\text { employees }\end{array}$ & $\begin{array}{l}\text { 5.1. Providing } \\
\text { true } \\
\text { information in } \\
\text { internal audit } \\
\text { reports }\end{array}$ & $\begin{array}{l}\text { Internal audit reports, } \\
\text { interviews with auditors: } \\
\text { (the head of the internal audit } \\
\text { unit, the head of the audited } \\
\text { structural unit or the senior } \\
\text { management has instructed } \\
\text { to change the internal audit } \\
\text { findings). }\end{array}$ & $\begin{array}{l}2 \text { - no detected cases of } \\
\text { altered findings; } \\
1 \text { - no direct evidence of cases } \\
\text { of altered findings; } \\
0 \text { - detected cases of altered } \\
\text { findings. }\end{array}$ & \\
\hline
\end{tabular}


Table 3 continued

\begin{tabular}{|c|c|c|c|c|}
\hline $\begin{array}{l}\text { Basic } \\
\text { element* }\end{array}$ & Factor** & $\begin{array}{c}\text { Checked, evaluated } \\
\text { document }\end{array}$ & Rating**** & Notes \\
\hline \multirow[t]{2}{*}{$\begin{array}{l}\text { 6. Competent } \\
\text { staff }\end{array}$} & $\begin{array}{l}\text { 6.1. Motivated } \\
\text { and } \\
\text { professional } \\
\text { internal audit } \\
\text { team }\end{array}$ & $\begin{array}{l}\text { Employment contracts, CVs, } \\
\text { certificates of professional } \\
\text { qualification of training of } \\
\text { internal auditors. }\end{array}$ & $\begin{array}{l}2 \text { - works more than } 2 \text { years; } \\
1 \text { - employees are working } \\
\text { more than a year; } \\
0 \text { - employees are changing } \\
\text { or do not work for more than } \\
1 \text { year. }\end{array}$ & \\
\hline & $\begin{array}{l}6.2 . \\
\text { Professional } \\
\text { growth and } \\
\text { training } \\
\text { of internal } \\
\text { auditor }\end{array}$ & $\begin{array}{l}\text { Training plan for the staff of } \\
\text { the internal audit unit. }\end{array}$ & $\begin{array}{l}2 \text { - regular training is planned } \\
\text { and implemented (complies); } \\
1 \text { - occasional training is } \\
\text { implemented (partially } \\
\text { complies); } \\
0 \text { - no training is planned } \\
\text { (does not comply). }\end{array}$ & \\
\hline $\begin{array}{l}\text { 7. Support by } \\
\text { stakeholders }\end{array}$ & $\begin{array}{l}\text { 7.1. } \\
\text { Development } \\
\text { of progressive } \\
\text { risk } \\
\text { management } \\
\text { procedure }\end{array}$ & $\begin{array}{l}\text { Internal audit plans, frequency } \\
\text { of their update, alignment } \\
\text { with the municipal strategic } \\
\text { plan. }\end{array}$ & $\begin{array}{l}2 \text { - risk management } \\
\text { improvement measures are } \\
\text { implemented; } \\
1 \text { - risk management practice } \\
\text { is implemented partially; } \\
0 \text { - unused risk management } \\
\text { practice. }\end{array}$ & \\
\hline $\begin{array}{l}\text { 8. Professional } \\
\text { auditing } \\
\text { standards }\end{array}$ & $\begin{array}{l}\text { 8.1. Complying } \\
\text { with the basic } \\
\text { principles of } \\
\text { international } \\
\text { professional } \\
\text { practice } \\
\text { standards of } \\
\text { internal audit }\end{array}$ & $\begin{array}{l}\text { Internal audit documents, } \\
\text { internal audit report. }\end{array}$ & $\begin{array}{l}2 \text { - full compliance; } \\
1 \text { - partial compliance; } \\
0 \text { - incompliance. }\end{array}$ & \\
\hline
\end{tabular}

Source: Table by author, * according to survey data 2010 IIARF CBOK survey data; ** adapted from 2015 IAIPF CBOK Global Survey; ${ }^{* * *}$ created by author in accordance with the basic element "organizational independence"

**** Valuation:

the assessment of a particular factor is $\mathbf{2}$, and this means that internal audit activities are in compliance with the requirements of professional practice standards or regulatory enactments, the measures specified in the methodology and plans are implemented, if between four and five conditions are met under 2.2; factor 5.1. has no detected cases of altered findings; factor 6.1 means that an employee is employed for more than 2 years, and other factors are fulfilled;

the assessment of a particular factor is 1, which means that in this factor internal audit activities are partially compliant with the requirements of professional practice standards or regulatory enactments; the measures specified in the methodology and plans are implemented in part, under factor 2.2 between two and three conditions are met; under factor 5.1 no direct evidence of the cases of alternate findings; factor 6.1 includes the employees working for more than a year, and other factors are partially fulfilled;

the assessment of a particular factor is $\mathbf{0}$, which means that the internal audit activities identified in this factor do not meet the requirements of professional practice standards or regulatory enactments; the measures specified in the methodology and plans have not been implemented, if one condition is fulfilled under factor 2.2 ; under factor 5.1 the cases of internal audit findings are detected; during assessment of factor 6.1, it has been established that the staff of the internal audit unit are changing and do not work for more than a year, and other factors fail. 
When the assessment is completed, the inspector counts the points obtained and identifies the corresponding group of the assessment of the internal audit performance, if the total score is:

Between 12 points and 24 points: the internal audit activity has been performed successfully. The internal audit function can serve as an example for other internal audit units. Internal audit's applied methods and best practices can be exemplified for other internal audit units (no rating factor is 0 and all twelve factors were rated 1 or 2).

Between 7 points and 11 points: the performance of the internal audit activity is assessed as partly successful. Internal audit is functional, but deficiencies identified affect the achievement of the internal audit function objective (at least seven analysed factors were rated 1);

Between 0 points and 6 points: internal audit does not add value. The internal audit function is necessary to improve the identified shortcomings detrimental to the internal audit functions of target (only one to six factors has been assessed as average or given the highest rating of 1 or 2).

To approve developed approach, an expert method was used. In May 2018, the author received the views and comments from nine experts. Six of the nine experts believe that, in general, the local government internal audit assessment approach developed by the author is usable, while three of the nine experts gave opinions that: 1) the approach is usable, but insufficient; 2) the approach is partially usable; 3 ) the approach can provide a partial assessment of the internal audit.

One expert considers that the local governments could use the selfassessment approach drafted by some state administration body, to which the author agrees, because the author offers the local governments to take over the direct state administration IA methodology, adapting it to local needs as one of the IA function solutions.

Three of the experts recommend using other factors that the author agrees with. Two experts recommend that the basic element "official mandate" be assessed as the mandate stipulated in law/regulation, as well as the proportion of audits carried out (compliance audits, performance audits). When describing the basic element of "unbiased employees", the experts recommend evaluating the ethical behaviour of employees, the skill to promote this behaviour in practice. In their turn, the experts advise that the basic element of "competent staff" be evaluated by introduction of recommendations, including a proportion of cancelled recommendations.

Two of the experts think that the assessment should include all IA standards, although the author agrees with this statement only in part, because at the 
initial stage of internal audit implementation it is not possible to implement all the standards, but the major stages should be evaluated, and eight of these the author has used as the basis for her approach, following the opinions of state administration professionals summarised in international research. Inclusion of all the standards in evaluation of local government's internal audit, to the opinion of the author, will be possible after the first five years of internal audit function implementation, when all the systems will be audited, and internal auditors will have obtained professional certificates and appropriate qualifications to fulfil their obligations under international professional practice standards.

One of the experts believes that the approach is missing some elements relating to the annual planning, which cannot be seen clearly, because the internal audit plans are included in the evaluation of basic elements like "competent management", "unlimited access to information and resources", "support by stakeholders", and "professional audit standards". The expert also has pointed out that the developed approach does not include implementation follow-up, which, in the author's opinion, is included in the factor "Complying with the basic principles of international professional practice standards of internal audit". The author believes that, according to the nature of international professional practice standards of internal audit, this element exactly encompasses all the IA processes that include job scheduling, task completion, reporting findings, and monitoring of the audit.

The author agrees with the recommendations of experts and considers that assessment of basic elements can be supplemented and an inspector can include additional documents for evaluation of each individual case depending on the municipality-specific factors (implemented international project, significant territorial changes, reconstruction, etc.).

In accordance with international standards of professional practice, the IAS provides added value to the organisation and its stakeholders given that it yields unbiased and sufficient assurance and contributes to the efficiency and usefulness of governance, risk management and control processes. In interviews with the municipality's management and heads of local government units it is possible to inquire whether the internal auditor is sufficiently competent, which is one of the essential elements of the internal audit's added value. In order to determine the added value of the local government's internal audit, the author has developed a list of internal audit's added value aspects or benefits for local governments based on the theoretical analysis. The author proposes to supplement this list with other specific and significant benefits for each municipality, as necessary. 
In assessing internal audit added value or benefit of each local government, the inspector (municipal management or an external inspector of internal audit unit) shall issue rating of 0,1 , or 2 , as follows: 0 , where the benefit does not improve functioning of the local government; 1 , where the benefit slightly improves municipal operations; and 2, where the benefit significantly improves work of local government.

The author also submitted the list of added value aspects or benefits of local government internal audit to the experts for evaluation, which was developed while drafting the doctoral thesis, and received the assessment from the aforementioned nine experts in May 2018. Two experts did not provide quantitative assessment of the added value aspects or benefits of the local government internal audit in improving municipal processes. One of the experts did not evaluate four processes, while six of the nine experts rated the added value aspects or benefits of the local government internal audit offered by the author in all the indicated processes (see Table 4).

Table 4. List of value added (benefits) of the local government internal audit according to the experts' evaluation

\begin{tabular}{|r|l|c|}
\hline No. & \multicolumn{1}{|c|}{ Added value or benefit created by the internal audit for local government } & $\begin{array}{c}\text { Average } \\
\text { evaluation } \\
\text { of benefit } \\
\text { by experts }\end{array}$ \\
\hline 1 & Improvement of management processes in local government & 2 \\
\hline 2 & $\begin{array}{l}\text { Improvement of the budget planning and implementation control process in local } \\
\text { government }\end{array}$ & 2 \\
\hline 3 & $\begin{array}{l}\text { Improvement of uniform processes of record keeping and document circulation in } \\
\text { the local government }\end{array}$ & 2 \\
\hline 4 & $\begin{array}{l}\text { Improvement of work and coordination processes in the organizational and } \\
\text { technical councils of the city and municipalities }\end{array}$ & 2 \\
\hline 5 & Improvement of personnel records' management & 2 \\
\hline 6 & Ensuring more efficient purchasing plans & 2 \\
\hline 7 & Improvement of procurement procedures & 2 \\
\hline 8 & Improvement of the registry department processes & 2 \\
\hline 9 & Improvement of accounting process & 1.86 \\
\hline 10 & Improving the financial reporting process & 1.86 \\
\hline 11 & Improvement of the process of preparing the annual report & 1.86 \\
\hline 12 & $\begin{array}{l}\text { Improvement of the function of recording and storing documents of the council and } \\
\text { the local government administration, archiving work provision }\end{array}$ \\
\hline 13 & More economical implementation of projects & 1.86 \\
\hline 14 & $\begin{array}{l}\text { Improvement of planning and implementation processes of municipal capital } \\
\text { companies }\end{array}$ & 1.86 \\
\hline 15 & Improving the quality of financial statements of municipality corporations & 1.86 \\
\hline
\end{tabular}


Table 4 continued

\begin{tabular}{|c|l|c|}
\hline No. & \multicolumn{1}{|c|}{ Added value or benefit created by the internal audit for local government } & $\begin{array}{c}\text { Average } \\
\text { evaluation } \\
\text { of benefit } \\
\text { by experts }\end{array}$ \\
\hline 16 & Improvement of construction management work processes & 1.83 \\
\hline 17 & Improvement of the processes of the orphan's court & 1.83 \\
\hline 18 & Promotion of cooperation with external audits & 1.71 \\
\hline 19 & Improvement of personnel selection processes & 1.71 \\
\hline 20 & Improvement of the evaluation process of municipal employees & 1.71 \\
\hline 21 & $\begin{array}{l}\text { Improvement of the support and advisory functions of institutions / institutions } \\
\text { established by the city council in the field of procurement }\end{array}$ & 1.71 \\
\hline 22 & Improvement of the accounting processes of municipal corporations & 1.71 \\
\hline 23 & Promotion of cooperation with the State Treasury & 1.67 \\
\hline 24 & Improvement of legal support processes & 1.57 \\
\hline 25 & Promoting employee awareness of improving the processes of local government & 1.43 \\
\hline
\end{tabular}

Source: Table by author

It follows from Table 4 that, according to the experts, the greatest added value of internal audit yields or significantly improves the benefits associated with developing management, budget planning and execution control, ensuring uniform work of office and circulation of documents, better coordination of organisational and technical aspects of council and local government, as well as improves procurement processes, and provides more efficient procurement plans. In their turn, the experts have assigned the minimum value to raising awareness among employees about improvement of municipal work and facilitating the process of legal support and cooperation with the State Treasury.

Consequently, the approach developed by the author is approbated by means of expert evaluation and is usable to evaluate the benefits of local government's internal audit. 

Ivita Faituša

Iekšèjā audita izvērtējums un pilnveidošanas iespēju analīze Latvijas valsts tiešajā pārvaldē un pašvaldībās, 2019

Latvijas Universitātes Akadēmiskais apgāds

Aspazijas bulvāris 5, Rīga, LV-1050

E-pasts: apgads@lu.lv 
Ivita Faituša, Dr. oec., LU Biznesa, vadỉbas un ekonomikas fakultātes Finanšu un grāmatvedỉbas nodalas docente un praktizējoša grāmatvede savā ārpakalpojumu uzṇēmumā. 2018. gadā aizstāvēja promocijas darbu, uz kura pamata ir tapusi zinātniskā monogrāfija.

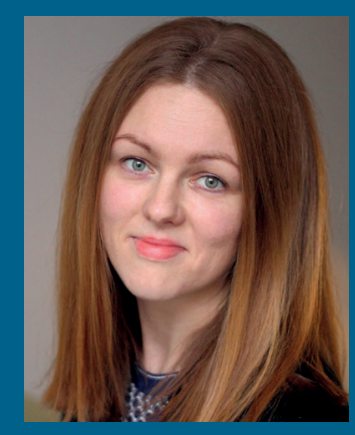

Dr. Ivita Faituša analysed the opportunities of the improvement of the internal audit of the Latvia state direct administration and local governments [..]. The author developed a model of internal audit implementation in the local governments of Latvia and an approach of assessment of internal audit of local governments.

Prof. Dr. Rasa Subačiene, Vilnius University, Faculty of Economics and Business Administration, Department of Accounting and Audit

Monogrāfija pēc satura, apjoma, zinātniskās novitātes un pielietoto pētijuma un datu apstrādes metožu korektuma, kā arī izstrādāto secinājumu un priekšlikumu teorētiskā un praktiskā nozīmīguma uzskatāma par nozìmīgu ieguldijumu Latvijas valsts pārvaldes un pašvaldỉbu audita sistēmas pilnveidošanā.

Latvijas Lauksaimniecības universitātes Finanšu un grämatvedības institūta direktore, profesore Dr. oec. Ingrïda Jakušonoka

Monogrāfija būs nozīmīgs devums iekšējā audita sistēmas pilnveidošanai valsts un pašvaldību iestādēs, un šis darbs būs ìpaši noderīgs studiju procesā ekonomikas, finanšu un grāmatvedības, sabiedrības pārvaldības studiju jomās.

Rēzeknes Tehnoloǵiju akadèmijas rektore, profesore Dr. oec. Iveta Mietule

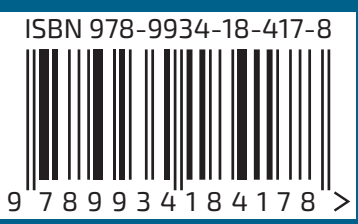

